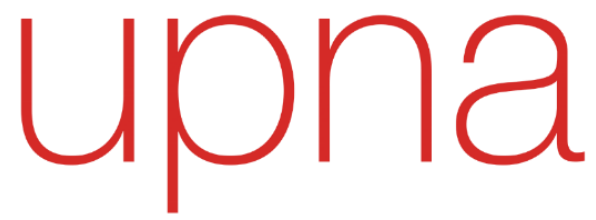

Universidad Pública de Navarra Nafarroako Unibertsitate Publikoa

Department of Economics

\title{
THE IMPORTANCE OF HEALTH TECHNOLOGY \\ ASSESSMENT TO ENSURE AN EFFICIENT AND \\ EQUITABLE ACCESS TO HIGH-COST THERAPIES
}

Thesis submitted for the doctorate degree by

Ion Agirrezabal

Thesis supervisors

Juan Cabasés

Eduardo Sánchez-Iriso

June 2020 
Bidea eder egin duten loreei 
upna 


\section{Acknowledgements / Esker onak / Agradecimientos}

En primer lugar, Juan y Eduardo, quisiera agradecer sinceramente todo vuestro interés, apoyo y dedicación que desde el primer momento habéis mostrado. Gracias por compartir vuestro conocimiento y ayudarme a llegar a este punto, y espero que vosotros también hayáis disfrutado de esta experiencia. Además de todo lo que conlleva la tesis, me llevo dos amigos expertos. Eskerrik asko.

I would also like to thank all my colleagues at Amgen that have supported and given me input throughout this period. In particular, I would like to thank Marco, Istvan and Gian Luca for their thoughts, feedback and availability to discuss any topics at any time. Y, cómo no, el gran Guillermo, y la gran Aesha también, por todos los ánimos y los buenos momentos que pasamos juntos en nuestra temporada en Suiza. Ha sido también vuestro apoyo el que me ha ayudado a alcanzar esta ikurriña! Eta ez dut ahaztuko ere Iñaki, hasiera-hasieratik eta inoiz zalantza barik laguntzeko izan duen prestutasuna. Mila esker!

Nola ez, Ama eta Aita, bizitza osoan zehar egin duzuen esfortzuagatik eta emandako laguntza eta babesagatik. Lan hau, azken batean, zuena ere badelako. Zorionak! Aitor, eta noski Ainhoari ere, emandako animo eta momentu on guztiengatik (azkenaldi honetan asko direnak). Beste senide eta lagundendako ere bai bada hau.

Eta, azkenik, azken urteotako bidelagun sutsuenari, atsedenik gabe hona heltzeko bultzatu nauena. Eta heldu gara, Lorea. Eskerrik ako! 
upna 


\section{Table of contents}

Executive summary

Chapter 1: Introduction

Chapter 2: Methodology and results of real-world cost-effectiveness of carfilzomib in combination with lenalidomide and dexamethasone in relapsed multiple myeloma using registry data

Chapter 3: Inequalities in prescription rates of anti-osteoporosis drugs in primary care in England: a practice-level prescribing data analysis in 20132018

Chapter 4: Real-world budget impact of the adoption of insulin glargine biosimilars in primary care in England (2015-2018)

Chapter 5: Future research directions

Chapter 6: Concluding remarks

Addendum 
upna

Universidad Pública de Navarra
Nafarroako Unibertsitate Publikoa 
Executive summary 
According to the World Health Organization, the key goal of health systems is to improve the average level of the population health and to reduce health inequalities in the population. In order to realise this goal, health system decision-makers need to decide which health technologies to invest in and which not to. Health technology assessment (HTA) provides a framework for decision-makers to make resource allocation and priority setting decisions based on the existing evidence. Considering the increasingly tight healthcare budgets and the rich pipeline of high-cost, innovative drugs very likely coming to market in the next few years, it is crucial that a robust and transparent HTA process be undertaken to assess these drugs, evaluating all aspects of the disease and treatment and involving all stakeholders affected. We conducted three standalone projects analysing different aspects of recently launched innovative drugs. In our first study, we combined high-quality sources of evidence, both from the real-world and randomised controlled trials, to evaluate the cost-effectiveness of carfilzomib for treating multiple myeloma patients. By harnessing the power of these data sources, we demonstrated that the reimbursement of carfilzomib is likely to represent an efficient allocation of existing resources. Despite the availability of good sources of evidence, the real-world distribution and use of innovative drugs may not be efficient nor fair, and this is what we demonstrated with our two other studies. Firstly, we showed that significant inequalities exist in the distribution of anti-osteoporosis drugs in primary care in England. The most striking case was that of denosumab, a high-cost innovative treatment, with prescriptions disproportionately concentrated among the least deprived. Substantial inequalities also exist in the use of insulin glargine biosimilars in primary care in England, even though guidelines and initiatives to promote the use of biosimilars have been put in place. In this study we observed that the real-world savings realised from the use of insulin glargine biosimilars represents a small proportion compared with what could have been achieved should their uptake had been higher. The results of these two studies, therefore, show that resource allocation may not be efficient nor fair in the real world, and similar situations are likely to exist in other disease areas. In summary, even though in many cases ample evidence exists to assist healthcare authorities making resource allocation decisions, we have demonstrated that resource allocation in the real world may not be optimal. We hope that our results provide useful insights so that healthcare authorities, in England but also in other countries, adopt measures that ensure the key objective of our healthcare systems is achieved: to improve the average level of the population health and to reduce health inequalities in the population. 
Munduko Osasun Erakundearen arabera, osasun-sistemen helburu nagusia populazioaren batazbesteko osasun maila hobetu eta osasun-desparekotasunak murriztea da. Helburu hau betetzeko osasun-sistemako erabakitzaileek zein osasun teknologiatan inbertitu eta zeinetan ez erabaki behar dute. Honela, osasun teknologien ebaluazioa (OTE) deritzonak, existitzen diren datu eta ebidentzia erabilita, baliabideak esleitu eta lehentasunak ezartzeko metodologia eskaintzen du. Osasungintzarako aurrekontu murritzak eta datozen urteetan merkaturatuko diren kostu altuko sendagaien kopuru esanguratsua kontuan harturik, OTErako prozesu sendo eta gardenak izatea garrantzi handikoa da, kostu altuko sendagai hauen inguruko alderdi guztiak ondo aztertu eta interes-talde guztien ikuspuntuak aintzat hartzen dituena. Berriki merkaturatutako sendagaien inguruko hiru proiektu burutu dugu lan honetan, OTEaren alderdi desberdinak uztartuz. Lehenik, kalitate altuko informazio-iturri desberdinak konbinatuz (entsegu kliniko aleatorioak [EKA] eta mundu errealeko ebidentzia [MEE]), mieloma anizkuna tratatzeko karfilzomib erabiltzearen kostu-eraginkortasuna aztertu dugu. Bi informazio-iturri hauen indarra baliatuta, karfilzomib erabiltzea eskuragai dauden baliabideen esleipen egokia izan litekeela erakutsi dugu. Informazio-iturri egokiak izanda ere, litekeena da sendagai berritzaile hauek populazioari modu ezeraginkor eta zuzengabean eskaintzea, eta hau da hain zuzen ere beste bi ikerketekin ikusi duguna. Lehenik, Ingalaterran osteoporosia tratatzeko sendagaien preskripziomailan desparekotasun esanguratsuak existitzen direla frogatu dugu. Desparekotasun hauek bereziki adierazgarriak dira denosumaben kasuan, kostu altuko sendagai berritzailea, zeinen preskripzio mailarik altuenak gabezia edo beharrik baxuena duten eskualdeetan biltzen diren. Bigarrenik, desparekotasun esanguratsuak ere existitzen dira insulina glarginaren biosimilarren erabilera mailan Ingalaterran, hauek sustatzeko gidak eta ekimenak izan badira ere. Honi lotuta, frogatu egin dugu insulina glarginaren biosimilarrak erabiltzearen ondorioz aurreztutako diru kantitatea erabilpen zabalago batekin aurrez litekeenaren proportzio txiki bat besterik ez dela. Bi ikerketa hauen emaitzen arabera, beraz, litekeena da baliabideen esleipena ez-eraginkorra eta ez-justua izatea, eta baliteke antzeko egoerak osasungintzako beste zeinbait alorretan existitzea. Laburbilduz, kasu askotan ebidentzia-maila zabala izan arren praktikan ikusitako baliabideen esleeipena ez-optimoa da. Emaitza hauen laguntzaz espero dugu, bai Ingalaterran baita gainontzeko herrialdeetan ere, agintariek gure osasun-sistemen helburu nagusia betetzeko beharrezko diren neurriak hartzea, honela populazioaren osasuna hobetu eta desparekotasun egoerak ekiditeko. 
Según la Organización Mundial de la Salud, el objetivo primordial de los sistemas de salud es mejorar el nivel medio de salud de la población y reducir las desigualdades relacionadas con la salud. Para cumplir este objetivo los decisores deben decidir en qué tecnologías sanitarias invertir y en cuáles no. La evaluación de tecnologías sanitarias (ETS) ofrece un marco de trabajo para que los decisores asignen los recursos disponibles y establezcan prioridades en base a la evidencia existente. Teniendo en consideración los presupuestos cada vez más ajustados y la cantidad de terapias innovadoras de alto coste que probablemente se lanzarán en los próximos años, es necesario llevar a cabo procesos de ETS robustos y transparentes que valoren todos los aspectos de la enfermedad y considere los puntos de vista de todos los grupos de interés. Así, hemos llevado a cabo tres proyectos para analizar distintos aspectos relacionados con medicamentos innovadores que se han lanzado al mercado recientemente. En el primer estudio combinamos fuentes de información de alta calidad, tanto del mundo real como de ensayos clínicos aleatorios, para evaluar el coste-efectividad de carfilzomib en el tratamiento de pacientes de mieloma multiple. Haciendo uso del potencial de cada una de estas fuentes, demostramos que el reembolso de carfilzomib representa, probablemente, una asignación de recursos eficiente. A pesar de la existencia de fuentes de información de buena calidad, la distribución y uso de los medicamentos innovadores en el mundo real puede no ser ni eficiente ni justo, y esto es precisamente lo que demostramos en los dos estudios posteriores. En el primero vimos que existen desigualdades significativas en la distribución de medicamentos para la osteoporosis en Inglaterra. El caso más llamativo es el de denosumab, un medicamento innovador de alto coste, cuyas prescripciones se concentran de forma desproporcionada entre la población menos desfavorecida. También demostramos la existencia desigualdades importantes en el uso de biosimilares de insulina glargina (también en atención primaria en Inglaterra), a pesar de que se hayan desarrollado guías e iniciativas para promover el uso de biosimilares. En este estudio observamos que los ahorros generados debido al uso de biosimilares de insulina glargina representa únicamente una proporción pequeña respecto a lo que el sistema de salud podría haber ahorrado si el uso de biosimilares fuse mayor. Los resultados de estos dos estudios, por tanto, demuestran que la asignación de recursos puede no ser ni eficiente ni equitativa en el mundo real, y es probable que existan situaciones similares en otras áreas terapéuticas. En definitiva, a pesar de que en muchos casos haya suficiente base científica para ayudar a las autoridades a asignar los recursos disponibles, hemos demostrado que es posible que en el mundo real los recursos no se asignen de manera óptima. Esperamos que nuestros resultados ayuden a las autoridades sanitarias, tanto en Inglaterra como en otros países, a adoptar medidas que aseguren el cumplimiento del objetivo central de nuestros sistemas de salud: mejorar 
el nivel medio de salud de la población y reducir las desigualdades existentes. 
upna

Universidad Pública de Navarra
Nataroako Unibertsitate Publikoa 
Chapter 1

Introduction 
A health system can be defined as the set of all actors, institutions and resources whose primary intent is to improve health [1]. All these actors and institutions include government organisations and agencies, both at the national and sub-national level; health service providers, including for and not-for-profit organisations; and citizens who become service users when they interact with health service providers [1]. As stated by the World Health Organization (WHO) the key goal of health systems and the reason why they exist is to improve health; importantly, there are two key components to this goal: to improve the average level of the population health and to reduce health inequalities in the population [1].

In order to realise this goal, as well as its two key components, health system decisionmakers need to decide which health technologies and interventions to invest in and which not to, either by not funding new technologies or withdrawing funds from those of low or no value $[2,3]$. Sound resource allocation policies are therefore becoming increasingly important, particularly considering the soaring healthcare costs and constrained budgets healthcare managers have at their disposal $[4,5]$. Drug or pharmaceutical spending represents nearly $20 \%$ of all healthcare expenditure across the Organisation for Economic Co-operation and Development (OECD) countries, and it has recently been predicted to keep growing in Europe in the next decade [6, 7]. This, along with the rising prices expected for innovative therapies coming to market in the near future, presents healthcare managers with considerable challenges, and putting in place or maintaining initiatives to achieve their goals is being and will be increasingly more problematic considering the tight healthcare funds $[8,9]$.

Health technology assessment (HTA) provides a framework for healthcare managers to make resource allocation and priority setting decisions based on the existing evidence: it is defined as a multidisciplinary process that summarises information in a systematic and robust manner about the medical, economic, organisational, social and ethical issues related to the use of a health technology [10]. With this, HTA measures the added value of a certain technology (most commonly a new technology), oftentimes in terms of clinical and economic terms, in comparison to another technology (most commonly the standard of care) and, ideally, can be used as a robust tool to identify the value-based price of innovations - the price level at which incentives and rewards for manufacturers are appropriately balanced against the sustainability of the healthcare system [11]. On the other hand, HTA should also be used as a mechanism to address the ethical aspects associated with health technologies, as well as designing the route to ensure the right to equal treatment $[12,13]$.

Pharmaceutical treatments for rare diseases (defined by the European Medicines Agency 
[EMA] as diseases with fewer than five cases in 10,000 people) represent a particular challenge for healthcare managers when making reimbursement or resource allocation decisions [14]. Given the small patient population, the clinical evidence to support market authorisation and subsequent reimbursement is usually limited for drugs targeting rare diseases, and these drugs are often launched at a price that may cause complications for budget holders $[15,16]$. Recently, the so-called advanced therapy medicinal products (ATMPs) have also moved to the centre stage of the affordability discussion. These are medicines for human use, most often to treat rare diseases, that are based on genes, tissues or cells, and offer ground-breaking new opportunities for the treatment of disease and injury [17]. Advanced therapy medicinal products have the potential to lead to significant lifelong benefits to patients with, in many cases, a short one-off intervention [18]. However, with prices of up to approximately $\$ 2$ million for a one-off treatment, ATMPs are creating and will create major affordability challenges, particularly if traditional evaluation and payment methods are considered [18, 19]. For this reason, it is crucial that a robust and transparent HTA process be undertaken to assess these high-cost drugs, evaluating all aspects of the disease and treatment and involving all stakeholders affected.

Once a drug receives market authorisation and a reimbursement approval, it will be rolled out to the patient population covered by the decision. As important as the preapproval assessment is the post-approval monitoring and evaluation of outcomes and costs associated with the drug, particularly when dealing with high-cost drugs with limited pre-approval clinical evidence. This is what is known as the analysis of the realworld (RW) evidence, which can help gather a complete picture of the effectiveness, tolerability and resource needs associated with a given treatment [20, 21]. Also, the analysis of the use and distribution of therapies in the RW can provide a good understanding of whether universal health coverage and inequalities in access to healthcare exist and, therefore, whether the key goal of health systems is being achieved [1].

With the rising number of high-cost drugs coming to market and projected to come to market in the next decade, we believe it is important to systematically evaluate whether the roll-out of these health technologies is being aligned with the key objectives of health systems: to improve the average level of the population health and to reduce health inequalities in the population $[1,22]$. For this purpose, we conducted three standalone projects analysing different aspects of recently launched, innovative drugs:

- In our first study we combined high-quality RW data with data from randomised controlled trials (RCTs) to estimate the cost-effectiveness of carfilzomib, an innovative drug used to treat multiple myeloma patients (considered a rare 
disease), in the RW. Randomised controlled trials are a good source of data for economic models but differences between RCT and RW conditions (e.g. patient characteristics, treatment patterns and dosing, use of supportive care) may limit the applicability of conclusions drawn from economic models using data from RCTs only. For this reason, our objective was to generate relevant costeffectiveness estimates of carfilzomib that healthcare managers can use to make evidence-based decisions regarding the value of this innovative technology.

- In our second study we investigated whether inequalities in the distribution of anti-osteoporosis drugs (low-cost bisphosphonates, raloxifene and high-cost denosumab) exist in primary care in England. Despite the long history of stressing the importance of ensuring healthcare provision according to clinical need in the England, examples of the so-called "inverse care law" (i.e. "the availability of good medical care tends to vary inversely with the need for it in the population served") abound in England and beyond [23]. We used rich, publicly-available datasets to analyse potential associations between antiosteoporosis prescription rates and the characteristics of patients being served (i.e. sex, age, ethnic group composition, rural-urban classification and income deprivation) and estimated concentration indices as summary measures of inequality. With this, our objective was to produce evidence of potential inequalities in access to treatments in the English primary care and steer discussions towards a more equitable healthcare system

- Biosimilars are medicines highly similar to another biological medicine already marketed in the European Union (i.e. the reference product), with no clinically meaningful differences in terms of efficacy or safety when compared with the reference product [24]. Biosimilars offer great opportunities to reduce healthcare expenditure, as long as market access is achieved [25]. The objective of our third study was to analyse the uptake of insulin glargine biosimilars in primary care in England, as well as the RW budget impact associated with the use of these biosimilars. Also, we estimated the missed savings (i.e. opportunities to increase savings) and analysed whether there were variations in the uptake of insulin glargine biosimilars across regions in England. The end-goal of our study was to encourage decision-makers in England to promote the use of best-value treatments in primary care, avoiding variation across regions and ensuring the right to equal treatment to all patients.

Finally, and considering recent discussions regarding affordability issues of ATMPs, we are planning on developing an early economic model that can assist manufacturers to generate the appropriate evidence and design the optimal positioning and pricing strategy for an ATMP, and also help decision-makers assess the existing evidence and 
understand the implications of reimbursing an ATMP under different payment scenarios. The model will be initially developed to consider the cost-effectiveness and budget impact of gene therapies in haemophilia but may be further developed to other disease areas such as cancer. 


\section{REFERENCES}

1. Murray, C.J.L., Evans, D.B., World Health Organization. Global Programme on Evidence for Health, P.: Health systems performance assessment : debates, methods and empiricism / edited by Christopher J. L. Murray, David B. Evans. In. World Health Organization, Geneva, (2003)

2. Elshaug, A.G., Hiller, J.E., Moss, J.R.: Exploring policy-makers' perspectives on disinvestment from ineffective healthcare practices. Int J Technol Assess Health Care 24(1), 1-9 (2008). doi:10.1017/S0266462307080014

3. World Health Organization: 2015 Global Survey on Health Technology Assessment by National Authorities. Main findings. https://www.who.int/health-technology-assessment/MD_HTA_oct2015_final_web2.pdf?ua=1 (2015). Accessed February 4th 2020

4. Arbel, R., Greenberg, D.: Rethinking cost-effectiveness in the era of zero healthcare spending growth. International Journal for Equity in Health 15(1), 33 (2016). doi:10.1186/s12939-016-0326-8

5. Stadhouders, N., Kruse, F., Tanke, M., Koolman, X., Jeurissen, P.: Effective healthcare cost-containment policies: A systematic review. Health Policy 123(1), 71-79 (2019). doi:https://doi.org/10.1016/j.healthpol.2018.10.015

6. Espin, J., Schlander, M., Godman, B., Anderson, P., Mestre-Ferrandiz, J., Borget, I., Hutchings, A., Flostrand, S., Parnaby, A., Jommi, C.: Projecting Pharmaceutical Expenditure in EU5 to 2021: Adjusting for the Impact of Discounts and Rebates. Appl Health Econ Health Policy 16(6), 803-817 (2018). doi:10.1007/s40258-018-0419-1 7. OECD: Health at a Glance 2019: OECD Indicators. https://www.oecd-ilibrary.org/docserver/4dd50c09en.pdf?expires $=1580813727 \& i d=i d \& a c$ name $=$ guest\&checksum $=4$ A7C475425D343DF4435730912CD7771 (2019).

8. Garrison, L.P., Jackson, T., Paul, D., Kenston, M.: Value-Based Pricing for Emerging Gene Therapies: The Economic Case for a Higher Cost-Effectiveness Threshold. J Manag Care Spec Pharm 25(7), 793-799 (2019). doi:10.18553/jmcp.2019.18378

9. Shukla, V., Seoane-Vazquez, E., Fawaz, S., Brown, L., Rodriguez-Monguio, R.: The Landscape of Cellular and Gene Therapy Products: Authorization, Discontinuations, and Cost. Hum Gene Ther Clin Dev 30(3), 102-113 (2019). doi:10.1089/humc.2018.201

10. World Health Organization: Health technology assessment. HTA Definitions. https://www.who.int/healthtechnology-assessment/about/Defining/en/ (2020). Accessed February 4th 2020

11. Moreno, S.G., Epstein, D.: The price of innovation - the role of drug pricing in financing pharmaceutical innovation. A conceptual framework. J Mark Access Health Policy 7(1), 1583536-1583536 (2019). doi:10.1080/20016689.2019.1583536

12. European Union Agency for Fundamental Rights: Inequalities and multiple discrimination in access to and quality of healthcare. https://fra.europa.eu/sites/default/files/inequalities-discrimination-healthcare_en.pdf(2013). Accessed February 5th 2020

13. Hofmann, B.: Why not integrate ethics in HTA: identification and assessment of the reasons. GMS Health Technol Assess 10, Doc04-Doc04 (2014). doi:10.3205/hta000120

14. European Medicines Agency: Development of medicines for rare diseases. https://www.ema.europa.eu/en/news/development-medicines-rare-diseases (2018). Accessed February 4th 2020 
15. Richter, T., Janoudi, G., Amegatse, W., Nester-Parr, S.: Characteristics of drugs for ultra-rare diseases versus drugs for other rare diseases in HTA submissions made to the CADTH CDR. Orphanet J Rare Dis 13(1), 15-15 (2018). doi:10.1186/s13023-018-0762-1

16. Schlander, M., Dintsios, C.-M., Gandjour, A.: Budgetary Impact and Cost Drivers of Drugs for Rare and Ultrarare Diseases. Value Health 21(5), 525-531 (2018). doi:10.1016/j.jval.2017.10.015

17. European Medicines Agency: Advanced therapy medicinal products: Overview. https://www.ema.europa.eu/en/human-regulatory/overview/advanced-therapy-medicinal-products-overview.

Accessed February 3rd 2020

18. Jönsson, B., Hampson, G., Michaels, J., Towse, A., von der Schulenburg, J.M.G., Wong, O.: Advanced therapy medicinal products and health technology assessment principles and practices for value-based and sustainable healthcare. Eur J Health Econ 20(3), 427-438 (2019). doi:10.1007/s10198-018-1007-x

19. Marsden, G., Towse, A., Pearson, S., Dreitlein, B., Henshall, C.: GENE THERAPY: Understanding the Science, Assessing the Evidence, and Paying for Value. https://www.ohe.org/publications/gene-therapyunderstanding-science-assessing-evidence-and-paying-value (2017). Accessed February 3rd 2020

20. Webster, J., Smith, B.D.: The Case for Real-world Evidence in the Future of Clinical Research on Chronic Myeloid Leukemia. Clin Ther 41(2), 336-349 (2019). doi:10.1016/j.clinthera.2018.12.013

21. Corrigan-Curay, J., Sacks, L., Woodcock, J.: Real-World Evidence and Real-World Data for Evaluating Drug Safety and Effectiveness. JAMA 320(9), 867-868 (2018). doi:10.1001/jama.2018.10136

22. Quinn, C., Young, C., Thomas, J., Trusheim, M., Group, M.N.F.W.: Estimating the Clinical Pipeline of Cell and Gene Therapies and Their Potential Economic Impact on the US Healthcare System. Value Health 22(6), 621626 (2019). doi:10.1016/j.jval.2019.03.014

23. Raine, R., Fitzpatrick, R., de Pury, J.: Challenges, solutions and future directions in evaluative research. Journal of Health Services Research \& Policy 21(4), 215-216 (2016). doi:10.1177/1355819616664495

24. European Medicines Agency and the European Commission: Biosimilars in the EU. Information guide for healthcare professionals. https:/www.ema.europa.eu/en/documents/leaflet/biosimilars-eu-information-guidehealthcare-professionals_en.pdf(2019). Accessed February 5th 2020

25. Smeeding, J., Malone, D.C., Ramchandani, M., Stolshek, B., Green, L., Schneider, P.: Biosimilars: Considerations for Payers. P T 44(2), 54-63 (2019). 
Chapter 2

Methodology and results of real-world cost-effectiveness of carfilzomib in combination with lenalidomide and dexamethasone in relapsed multiple myeloma using registry data

Eur J Health Econ. 2019 Oct 31. doi: 10.1007/s10198-019-01122-6 


\begin{abstract}
Objective: To predict the real-world (RW) cost-effectiveness of carfilzomib in combination with lenalidomide and dexamethasone (KRd) versus lenalidomide and dexamethasone $(\mathrm{Rd})$ in relapsed multiple myeloma $(\mathrm{MM})$ patients after one to three prior therapies.
\end{abstract}

Methods: A partitioned survival model that included three health states (progressionfree, progressed disease and death) was built. Progression-free survival (PFS), overall survival (OS) and time to discontinuation (TTD) data for the Rd arm were derived using the Registry of Monoclonal Gammopathies in the Czech Republic; the relative treatment effects of KRd versus Rd were estimated from the phase 3, randomised, ASPIRE trial, and were used to predict PFS, OS and TTD for KRd. The model was developed from the payer perspective and included drug costs, administration costs, monitoring costs, palliative care costs and adverse-event related costs collected from Czech sources.

Results: The base case incremental cost effectiveness ratio for KRd compared with $\mathrm{Rd}$ was $€ 73,156$ per quality-adjusted life year (QALY) gained. Patients on KRd incurred costs of $€ 117,534$ over their lifetime compared with $€ 53,165$ for patients on $\mathrm{Rd}$. The QALYs gained were 2.63 and 1.75 for patients on $\mathrm{KRd}$ and $\mathrm{Rd}$, respectively.

Conclusions: Combining the strengths of randomised controlled trials and observational databases in cost-effectiveness models can generate policy-relevant results to allow well-informed decision-making. The current model showed that KRd is likely to be costeffective versus Rd in the RW and, therefore, the reimbursement of KRd represents an efficient allocation of resources within the healthcare system.

\title{
KEYWORDS
}

ASPIRE; Carfilzomib; Cost-effectiveness; Multiple myeloma; Real world; Registry of Monoclonal Gammopathies.

\section{KEY ABBREVIATIONS}

AE, adverse event; BSA, body surface area; $\mathrm{KRd}$, carfilzomib/lenalidomide/dexamethasone; MM, multiple myeloma; OS, overall survival; PFS, progression-free survival; QALY, quality-adjusted life year; RCT, randomised controlled trial; $\mathrm{Rd}$, lenalidomide/dexamethasone; RDI, relative dose intensity; RMG, Registry of Monoclonal Gammopathies; RW, real world; SPC, Summary of Product Characteristics; SÚKL, State Institute for Drug Control in the Czech Republic; TTD, time to discontinuation. 


\section{INTRODUCTION}

Multiple myeloma (MM), generally considered incurable, is the second most common haematological malignancy and accounts for approximately $0.8 \%$ of all new cancer cases worldwide [1-3]. The incidence and survival of cancer patients, in general, as well as of MM in particular, have increased in the past few decades, and a similar trend has been observed for the economic burden of cancer management [4-7]. For this reason, and particularly under a situation of budget constraints that many healthcare decisionmakers are facing, the value of cancer drugs is increasingly being scrutinised [7, 8].

Cost-effectiveness studies, along with other health economic studies such as budget impact analyses, represent essential tools that allow healthcare managers to make evidence-based decisions regarding the value and affordability of health technologies. Randomised controlled trials (RCTs) are the gold standard to identify relative treatment effects and are well suited to produce evidence for regulatory approval; [6] however, Sullivan et al. and Neyt et al. argue that results from cost-effectiveness analyses based solely on RCTs may not predict the benefits and costs of new treatments in real world (RW) patients, and that these analyses should be supplemented with information collected from observational databases when available [6,9]. In fact, there are differences between RCTs and the RW that may limit the applicability of economic models based on RCTs only in RW populations: potential differences in patient selection criteria (i.e. stricter inclusion and exclusion criteria in RCTs, in general, as compared with RW studies), treatment patterns and dosing, use of supportive care and extent of follow-up (i.e. patients' adherence to treatment tends to be better in RCTs, as compared with RW studies), or differences in care across countries, particularly in the context of oncology, are some examples $[6,8,10]$. Observational databases, however, capture characteristics and outcomes of patients receiving treatment in real life: the Registry of Monoclonal Gammopathies (RMG), for instance, captures a wide range of data of MM patients in the Czech Republic, and comparisons across published studies demonstrate that differences exist between RCTs and the RW, e.g. outcomes of patients treated with lenalidomide and dexamethasone (Rd) are considerably lower in RW patients compared with those in recent RCTs [11-16]. Additionally, the limited time duration of RCTs pose an extra hurdle for the generalisation of economic model results in the RW, as the time horizon of economic models often requires extrapolation of clinical data well beyond the trial duration; [17] in registries and observational databases patients may be followed for longer periods and consequently the uncertainty around long-term estimates may be considerably lower than that obtained as a result of extrapolation of trial data $[9,17,18]$. Mullins et al. claim that this RW evidence is critical for coverage decisions by payers and treatment decisions by physicians and patients, and for that reason economic models 
that combine the strengths of both RCTs (i.e. relative treatment effects) and RW data (i.e. baseline risks such as progression-free survival [PFS] and overall survival [OS] in patients receiving the comparator treatment) may provide more relevant and less uncertain estimates than those based on RCTs only, as long as the evidence available from observational databases is robust and representative of the RW patient population $[8,9,19,20]$. Therefore this modelling approach is deemed to be appropriate to support well-informed decision-making in the RW, as it may minimise the risk of inefficient allocation of resources, including the chances of neglecting the access to more efficacious therapies erroneously considered not cost-effective, as well as the likelihood of inaccurate budget impact predictions [8, 9, 19, 20].

Several studies have reported the RW cost-effectiveness of cancer drugs combining data from RCTs and observational databases, reinforcing the validity of the approach described above. For instance, Seferina et al. estimated the RW cost-effectiveness of trastuzumab plus chemotherapy versus chemotherapy alone in early breast cancer combining RW outcomes for the trastuzumab arm with treatment effect estimates (expressed as hazard ratios [HRs] of trastuzumab versus control arm) from the HERA trial $[21,22]$. Similarly, van Gils et al. analysed the RW cost-effectiveness of oxaliplatin in colon cancer, for which they combined published efficacy data from the MOSAIC trial with RW data from a Dutch population-based observational study [10]. Other studies have adopted a similar approach for the estimation of RW cost-effectiveness of health technologies, including disease areas other than cancer such as cardiovascular disease or chronic obstructive pulmonary disorder [23-26].

The aim of the present study was to estimate the RW cost-effectiveness of carfilzomib in combination with lenalidomide and dexamethasone (KRd) compared with Rd for the treatment of relapsed MM after one to three prior therapies. For this purpose observational data for Rd from the RMG in the Czech Republic were combined with treatment effect estimates from the ASPIRE trial, a randomised, open-label, multicentre, phase 3 study that evaluated the safety and efficacy of KRd compared with $\mathrm{Rd}$ in relapsed MM patients who had received one to three prior treatments $[12,15,16]$.

\section{METHODS}

\section{Data sources}

Real-world data for the Rd arm were collected from the RMG [16]. This database was set up in 2007 and captures all newly diagnosed MM patients treated in 19 Czech hospitals (16 hospitals reported relevant data at the time of data collection), covering approximately $80 \%$ of all newly diagnosed $\mathrm{MM}$ and monoclonal gammopathy of 
unknown significance (MGUS) patients in the Czech Republic [16]. The RMG is considered the most comprehensive database in Central Europe, and includes information on MM disease status and history (e.g. laboratory tests performed and results, disease stage), treatment received (e.g. specific regimen, time to treatment discontinuation [TTD], line of therapy) and outcomes (e.g. PFS and OS). Data from the intention-to-treat population in the ASPIRE RCT were also used to inform the costeffectiveness model [15]. These two data sources were combined in such a way that baseline risks of events with Rd treatment were estimated from the RMG, whereas the relative treatment effects of KRd versus Rd were estimated from ASPIRE, as suggested and presented in the literature [9, 10, 21-26]. A comparison of baseline characteristics of Rd patients in RMG and ASPIRE are presented in the online resources (see Supplementary Table 2.1). Patients of the RMG registry were older, had worse performance status, were more likely to be refractory to prior bortezomib and immunomodulatory treatment, and were less likely to have received stem cell transplantation. Cost data were collected from Czech sources.

\section{Model structure}

A partitioned survival model was built with three mutually exclusive health states: progression-free (PF), progressive disease (PD) and death (Figure 2.1). Transitions to the death state could occur from either the PF or PD health states, death being an absorbing state. The proportions of patients in each health state over time were estimated using the PFS and OS curves in each treatment arm. A cycle length of 28 days was implemented in line with the carfilzomib administration schedule [15]. This modelling approach has been extensively used for economic models in MM, including the costeffectiveness model of KRd versus Rd from a US perspective authored by Jakubowiak et al. [27-33]

Figure 2.1. Model structure.

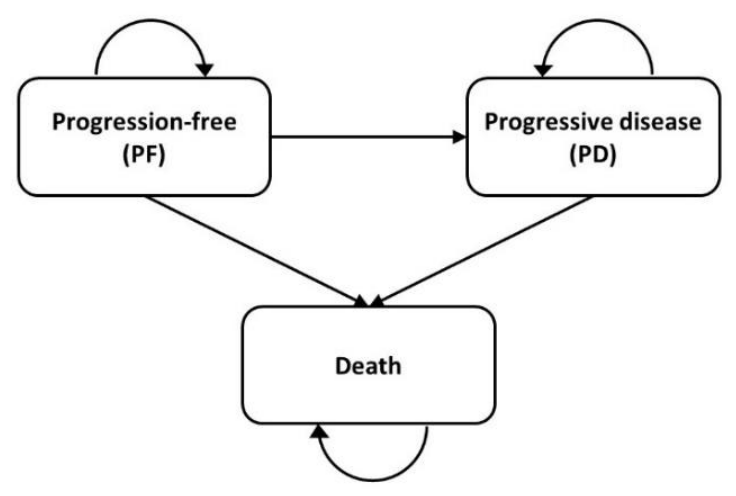




\section{Regimens}

$\mathrm{Rd}$ was chosen as the only comparator treatment because it is the most widely used treatment regimen in relapsed MM after one to three prior therapies in the Czech Republic. Although bortezomib-based and pomalidomide treatments are also available, treatment patterns data demonstrate that the market share of $\mathrm{Rd}$ was approximately 70 $75 \%$ in 2018 [34]. This comparator choice was supported by representatives of a local expert society (Czech Myeloma Group).

Carfilzomib was implemented in the model as per the cycle dosing in the carfilzomib summary of product characteristics (SPC) and ASPIRE study [15, 35]. Dosing for carfilzomib is based on body surface area (BSA), and the reference value considered for this analysis was $1.73 \mathrm{~m} 2$, in line with previous decisions by the State Institute for Drug Control in the Czech Republic (SÚKL) [36]. Dosing for $\mathrm{Rd}$ was based on the lenalidomide SPC [37]. Additional details are available elsewhere [15, 32].

\section{Treatment effectiveness}

The PFS, OS and TTD curves for patients receiving Rd were estimated from the RMG. The RMG provided separate PFS, OS and TTD data on patients treated with Rd in second, third and fourth lines (2L, 3L and 4L), and median values are shown in Table 2.1. Kaplan-Meier (KM) curves for PFS and OS are provided in the online resources (Supplementary Figure 2.1 and 2.2).

Table 2.1. Median PFS, OS and TTD values for patients receiving Rd in the RMG.

\begin{tabular}{|l|c|c|c|}
\hline Outcome & 2L $(\mathbf{n}=\mathbf{1 1 3})$ & 3L $(\mathbf{n}=\mathbf{9 6})$ & 4L $(\mathbf{n}=\mathbf{1 5})$ \\
\hline $\begin{array}{l}\text { Median PFS, months (95\% } \\
\text { CI) }\end{array}$ & $8.7(7.3-10.1)$ & $6.6(5.3-8.0)$ & $5.7(1.6-9.7)$ \\
\hline $\begin{array}{l}\text { Median OS, months (95\% } \\
\text { CI) }\end{array}$ & $26.2(21.7-30.8)$ & $12.6(11.4-13.7)$ & $\begin{array}{c}10.6(5.7- \\
15.6)\end{array}$ \\
\hline $\begin{array}{l}\text { Median TTD, months (95\% } \\
\text { CI) }\end{array}$ & $7.2(\mathrm{NA})$ & $5.2(\mathrm{NA})$ & $3.8(\mathrm{NA})$ \\
\hline
\end{tabular}

1L, first line; 2L, second line; 3L, third line; CI, confidence interval; n, number of patients; NA, not available; OS, overall survival; PFS, progression-free survival; Rd, lenalidomide/dexamethasone; RMG, Registry of Monoclonal Gammopathies; TTD, time to discontinuation.

Survival analyses were conducted according to the National Institute of Health and Care Excellence (NICE) guideline and parametric models were fitted to PFS, OS and TTD data in each line (exponential, Weibull, Gompertz, loglogistic, lognormal and 
generalised gamma models) [20]. The suitability of each model was assessed through visual comparison of the fit versus the corresponding KM curve, goodness-of-fit statistics (Akaike information criterion [AIC]), and plausibility of long-term extrapolations. The best fitting parametric models in each line were selected, and a weighted average of these curves was computed using the number of patients in each line in RMG (see Table 2.1) to derive PFS, OS and TTD baseline curves for the overall patients population with one to three prior lines.

The relative treatment effect estimates for KRd versus Rd, expressed as HRs (for PFS and OS), were derived using ASPIRE patient-level data. PFS data were available from the first ASPIRE data cutoff in June 2014 (median follow-up 31 months), while mature OS data were available from a later data cut in April 2017 (median follow-up 67 months) $[15,38]$. To assess the proportionality of the hazards, log-cumulative hazard plots were evaluated, along with tests of interaction between treatment effect and time with a Cox model $[20,32,39]$ The PFS and OS HRs of KRd versus Rd were calculated with separate multiple Cox models using a number of baseline characteristics as covariates to reduce potential imbalances between treatment arms [40]. Specifically, all covariates that were prespecified for subgroup analyses in ASPIRE were included in the initial models. Covariates to be included in the final models were identified by first testing each variable independently; it was assessed whether the variable was associated with the outcome (at a significance level of 0.2). Variables identified in this process were then trimmed one at a time (significance level of 0.1 or higher) with a stepwise variable selection procedure to derive the final PFS and OS model. This stepwise procedure examined the association between baseline covariates and outcomes (PFS and OS) as well as the effects of interaction between treatment and covariates by including treatment, each of the covariates and treatment-covariate interaction terms as predictor variables. The resulting PFS and OS HRs were applied to baseline risks derived from the RMG to estimate the PFS and OS curves for KRd, respectively (see online resources, Supplementary Table 2.2 and 2.3). The TTD curve for KRd was calculated applying the PFS HR to the Rd TTD curves from the RMG in order to simulate that the efficacy associated with a particular treatment may be associated with the amount of treatment received by patients.

\section{Health-state utilities}

The RMG does not record preference-based utility data for MM patients, and these were not collected in the ASPIRE trial. For these reasons utility inputs were estimated by combining utilities from the literature and trial-based patient-reported outcomes. The methodology for estimating these utilities and the utility values used in the model have 
been described by Jakubowiak et al. [32]. The impact of adverse events (AEs) on healthrelated quality of life was also considered as part of this evaluation by incorporating utility decrements (or disutilities) associated with each relevant AE taking into account the duration of the AE [29]. The approach adopted and the disutility values implemented have also been detailed by Jakubowiak et al. [32]. The implicit assumption associated with this approach was that utilities in RMG patients were considered to be similar to those in ASPIRE patients.

\section{Costs}

The model was developed from the payer perspective, and costs from Czech sources were used to illustrate the current RW cost-effectiveness model. Costs were obtained in Czech korunas, and then translated into euros using the average exchange rate between June 11th, 2017, and December 11th, 2017 (1 EUR = 25.931 CZK) [41]. In line with the published literature, the following cost inputs were considered: drug costs, administration costs, monitoring costs, palliative care costs and AE-related costs [32, 33].

\section{Initial drug costs}

Drug prices were collected from the Czech list of reimbursed medicinal products as of December 1st, 2017 [42]. To calculate drug costs, mean weight or BSA of patients, available strengths (for a vial, capsule or tablet), price of a pack and the number of vials, capsules or tablets in a pack were considered. Also, in order to appropriately model the treatment acquisition costs based on the actual doses captured in the RMG registry, and in alignment with the literature, relative dose intensity (RDI) was applied to reflect the impact of dose reductions and interruptions on drug acquisition costs [43-47]. In the Rd arm, the RDI values were calculated from the RMG dividing the mean dose of lenalidomide per administration (in $\mathrm{mg}$ ) by $25 \mathrm{mg}$ (i.e. the maximum dose as per the lenalidomide label). For the KRd arm, RDI values from ASPIRE were used, as it represented the best source of evidence for patients receiving all three drugs in combination. Carfilzomib wastage was assumed to be negligible, due to the current availability of 60,30 and $10 \mathrm{mg}$ vials, and therefore the cost per $\mathrm{mg}$ was used in the model. Information on the dosing for each treatment, along with the RDI and the cost per cycle for each drug, are presented in Table 2.2. 
Table 2.2. KRd and Rd drug costs.

\begin{tabular}{|c|c|c|c|c|c|c|}
\hline $\begin{array}{l}\text { Treatment } \\
\text { regimen }\end{array}$ & $\begin{array}{c}\text { Regimen } \\
\text { components }\end{array}$ & Unit & $\begin{array}{c}\text { Unit } \\
\operatorname{cost}(€)\end{array}$ & $\begin{array}{c}\text { Dosing } \\
\text { schedule }\end{array}$ & RDI & $\begin{array}{c}\text { Drug } \\
\text { cost per } \\
\text { 28-day } \\
\text { model } \\
\text { cycle }(€)\end{array}$ \\
\hline \multirow{5}{*}{$\mathrm{KRd}$} & $\begin{array}{l}\text { Carfilzomib } \\
\text { (Cycle 1) }\end{array}$ & $\begin{array}{c}1 \times 60 \mathrm{mg} \\
\text { vial }\end{array}$ & $1,400.03$ & $\begin{array}{c}20 \mathrm{mg} / \mathrm{m}^{2} \text { on } \\
\text { Days } 1 \text { and } 2, \\
27 \mathrm{mg} / \mathrm{m}^{2} \text { on } \\
\text { Days } 8,9, \\
15 \text {, and } 16\end{array}$ & $91.0 \%$ & 5,437 \\
\hline & $\begin{array}{l}\text { Carfilzomib } \\
\text { (Cycles 2-12) }\end{array}$ & $\begin{array}{c}1 \times 60 \mathrm{mg} \\
\text { vial }\end{array}$ & $1,400.03$ & $\begin{array}{l}27 \mathrm{mg} / \mathrm{m}^{2} \text { on } \\
\text { Days } 1,2,8, \\
9,15, \text { and } 16\end{array}$ & $91.0 \%$ & 5,951 \\
\hline & $\begin{array}{l}\text { Carfilzomib } \\
\text { (Cycles } 13 \text { and } \\
\text { beyond) }\end{array}$ & $\begin{array}{c}1 \times 60 \mathrm{mg} \\
\text { vial }\end{array}$ & $1,400.03$ & $\begin{array}{c}27 \mathrm{mg} / \mathrm{m}^{2} \text { on } \\
\text { Days } 1,2, \\
15, \text { and } 16\end{array}$ & $91.0 \%$ & 3,967 \\
\hline & Lenalidomide & $\begin{array}{c}21 \times 25 \mathrm{mg} \\
\text { tablets }\end{array}$ & $5,116.65$ & $\begin{array}{l}25 \mathrm{mg} \text { orally } \\
\text { on days } 1-21\end{array}$ & $80.5 \%$ & 4,119 \\
\hline & Dexamethasone & $\begin{array}{c}20 \times 20 \mathrm{mg} \\
\text { tablets }\end{array}$ & 25.33 & $\begin{array}{c}40 \text { mg orally } \\
\text { on days } 1,8, \\
15 \text { and } 22\end{array}$ & $82.8 \%$ & 8 \\
\hline \multirow{2}{*}{$\mathrm{Rd}$} & Lenalidomide & $\begin{array}{c}21 \times 25 \mathrm{mg} \\
\text { tablets }\end{array}$ & $5,116.65$ & $\begin{array}{l}25 \mathrm{mg} \text { orally } \\
\text { on days } 1-21\end{array}$ & $88.2 \%$ & 4,512 \\
\hline & Dexamethasone & $\begin{array}{c}20 \times 20 \mathrm{mg} \\
\text { tablets }\end{array}$ & 25.33 & $\begin{array}{c}40 \mathrm{mg} \text { orally } \\
\text { on days } 1,8 \text {, } \\
15 \text { and } 22\end{array}$ & $88.2 \%$ & 9 \\
\hline
\end{tabular}

KRd, carfilzomib/lenalidomide/dexamethasone; Rd, lenalidomide/dexamethasone; RDI, relative dose intensity.

\section{Subsequent treatment costs}

Drug prices were collected from the Czech list of reimbursed medicinal products as of December 1st, 2017 [42]. The model considered that patients in the PD state may receive subsequent active treatments. Prior to receiving subsequent treatments, patients experience a treatment-free interval of three cycles (the same in both treatment arms) during which no treatment costs were applied [32]. The proportions of patients progressing and receiving subsequent treatments were estimated from the RMG: 54.1\% of patients went on to receive subsequent treatments (the same in both treatment arms). These patients entered a 'tunnel state' consisting of a mix of treatments derived from patients captured in the RMG, whom were treated following the Czech Myeloma Group 
guidelines for MM (Table 2.3) [48]. The detailed proportions of patients receiving each subsequent treatment were collected from the RMG and are provided in the online resources (Supplementary Table 2.4). The RDI was assumed to be $100 \%$ for all subsequent treatments due to the lack of data, and overall duration for subsequent treatments was assumed to be 5 cycles for both $\mathrm{KRd}$ and $\mathrm{Rd}$, based on data from the RMG (additional details are provided in the online resources; Supplementary Table 2.5).

Table 2.3. Unit costs and dosing schedule of subsequent treatments.

\begin{tabular}{|l|c|c|c|c|}
\hline Treatment & Unit & $\begin{array}{c}\text { Unit } \\
\text { cost (€) }\end{array}$ & Dosing schedule & $\begin{array}{c}\text { Drug cost } \\
\text { per 28-day } \\
\text { model cycle } \\
\text { (€) }\end{array}$ \\
\hline \multirow{3}{*}{$\begin{array}{l}\text { Bortezomib } \\
\text { (Actavis) }^{\mathrm{a}}\end{array}$} & $1 \times 3.5 \mathrm{mg}$ vial & 161.45 & $\begin{array}{c}\text { 4 subcutaneous } \\
\text { administrations; each } \\
\text { administration of } 1.3 \\
\text { mg/m }\end{array}$ & 415 \\
\hline \multirow{3}{*}{ Thalidomide }
\end{tabular}

${ }^{a}$ Bortezomib SPC provides information for a 3-week (21-day) long cycle, and frequency was transformed to a 4-week (28-day) long cycle.

${ }^{\mathrm{b}}$ Dosing schedule informed by expert opinion. Minimum cost per mg was chosen.

${ }^{c}$ Dosing schedule informed by expert opinion. Alternatively, patients could also receive $300 \mathrm{mg} / \mathrm{m}^{2}$ on Day 1 and Day 15 of a 28-day cycle. Minimum cost per mg was chosen.

${ }^{\mathrm{d}}$ Minimum cost per mg was chosen.

\section{Administration costs}

Carfilzomib and cyclophosphamide were assumed to be administered intravenously at the hospital (outpatient) at a cost of $€ 27.19$ per administration [49,50]. Costs of oral and 
subcutaneous administrations were assumed to be zero and therefore no other drug was considered to incur any administration costs.

\section{Monitoring costs}

Monitoring items were derived from the NICE technology appraisal of panobinostat for $\mathrm{MM}$, and included skeletal survey by X-ray, laboratory analyses (serum protein assessment, haematology, blood chemistry and thyroid function tests) and specialist visits [51]. Resource use was estimated from a study that involved seven centres of excellence for MM treatment in the Czech Republic, and costs were collected from the latest available health checklist published by the Ministry of Health [49]. These inputs yielded a figure of $€ 31.46$ for monitoring costs per patient per cycle, which was assumed to be the same in both treatment arms. Additional details are provided in the online resources (Supplementary Table 2.6).

\section{Palliative care costs}

All progressed patients that were not in either the treatment-free interval or receiving subsequent treatments were assumed to incur a standard cost for palliative care, with a cost per cycle of $€ 1093$ [52].

\section{Adverse event costs}

Adverse events were included in the model if they were Grade 3 or Grade 4 with an incidence equal or greater than 2\% in ASPIRE. Monthly probabilities of AEs were calculated from the percentages of patients experiencing an AE over the course of the ASPIRE trial and from the mean time on treatment in ASPIRE (KRd $=88.1$ weeks; $\mathrm{Rd}$ $=70.7$ weeks). Patients were assumed to be at a constant risk of having an AE while on treatment in the PF state. Unit costs for AEs were identified from the list of Diagnosis Related Group (DRG) codes valid for 2017 [53]. Table 2.4 displays the monthly probabilities and unit costs of AEs included in the model. 
Table 2.4. Estimated monthly probabilities of Grade 3 or Grade 4 adverse events and the unit costs (with the corresponding DRG code) of each adverse event.

\begin{tabular}{|c|c|c|c|c|c|c|}
\hline \multirow{2}{*}{ Adverse event } & \multicolumn{2}{|c|}{$\%$ Grade 3} & \multicolumn{2}{|c|}{$\%$ Grade 4} & \multirow{2}{*}{$\begin{array}{c}\text { Unit cost } \\
(€)\end{array}$} & \multirow{2}{*}{$\begin{array}{c}\text { DRG } \\
\text { inpatient } \\
\text { code }\end{array}$} \\
\hline & KRd & Rd & KRd & Rd & & \\
\hline \multicolumn{7}{|c|}{ Blood and Lymphatic System Disorders } \\
\hline Neutropenia & $1.18 \%$ & $1.12 \%$ & $0.28 \%$ & $0.42 \%$ & 964.02 & $16341-3$ \\
\hline Anaemia & $0.34 \%$ & $0.51 \%$ & $0.09 \%$ & $0.08 \%$ & $1,001.35$ & $16331-3$ \\
\hline Thrombocytopenia & $0.37 \%$ & $0.42 \%$ & $0.37 \%$ & $0.21 \%$ & 964.02 & $16341-3$ \\
\hline \multicolumn{7}{|c|}{ Gastrointestinal Disorders } \\
\hline Diarrhoea & $0.08 \%$ & $0.13 \%$ & $0.00 \%$ & $0.00 \%$ & 533.34 & $06371-3$ \\
\hline Vomiting & $0.00 \%$ & $0.00 \%$ & $0.00 \%$ & $0.00 \%$ & 716.59 & 17332 \\
\hline \multicolumn{7}{|c|}{ Respiratory, Thoracic and Mediastinal Disorders } \\
\hline Dyspnoea & $0.08 \%$ & $0.02 \%$ & $0.00 \%$ & $0.00 \%$ & 776.06 & $0411-3$ \\
\hline \multicolumn{7}{|c|}{ General Disorders and Administration Site Conditions } \\
\hline Fatigue & $0.30 \%$ & $0.29 \%$ & $0.00 \%$ & $0.00 \%$ & 716.59 & 17332 \\
\hline \multicolumn{7}{|c|}{ Nervous System Disorders } \\
\hline Peripheral neuropathy & $0.08 \%$ & $0.10 \%$ & $0.00 \%$ & $0.00 \%$ & 716.59 & 17332 \\
\hline
\end{tabular}

DRG, Diagnosis Related Group; KRd, carfilzomib/lenalidomide/dexamethasone; Rd, lenalidomide/dexamethasone.

\section{Discount rate}

A discount rate of $3.0 \%$ per annum was applied for costs and outcomes, in line with the SÚKL methodological guidance [54].

\section{Time horizon}

The median age at baseline in the RMG registry and ASPIRE study was 67 and 64 years, respectively, but patients as young as 49 and 31 years were included in the RMG registry and ASPIRE study, respectively [12,15]. Therefore a lifetime time horizon (40 years) was considered appropriate in the base case given the patients' heterogeneity in terms of age at diagnosis. This time horizon would allow capturing all costs and consequences of all patients over their lifetime.

\section{Sensitivity analyses}

Univariate deterministic sensitivity analyses (DSA) were conducted to test the effects of parameter uncertainty within the model. The model parameters were varied using $95 \%$ confidence intervals (CIs), if available; if these were not available, standard probability distributions were assigned to model parameters and lower and upper limits were calculated as the 2.5th and 97.5th percentile, respectively, assuming a standard error 
(SE) equal to $10 \%$ of the base case values. Lower and upper bounds of curve fit parameters were estimated with their corresponding variance-covariance matrices within a multinormal distribution. Probabilistic sensitivity analyses (PSA) were also conducted. Standard probability distributions were assigned to model parameters and 5,000 Monte Carlo simulations were computed. Finally, a number of scenario analyses were performed: (1) only add-on therapy costs, i.e. carfilzomib costs, were considered, given that $\mathrm{Rd}$ has previously been appraised and recommended as a cost-effective treatment option, including in the Czech Republic; [55-57] (2) unadjusted PFS and OS HRs (i.e. the HR from the primary ASPIRE publication for PFS and the unadjusted HR estimated for OS using the data made available in April 2017); [15,37] (3) same utilities for KRd and Rd arms, assuming KRd utilities for both arms; (4) time horizon of 20 years; (5) discount rate of $0 \%$ for both costs and outcomes, as per the SÚKL guidelines; [54] and (6) discount rate of 5\% for both costs and outcomes, as per the SÚKL guidelines [54].

\section{RESULTS}

\section{Base case analysis}

The survival analyses for PFS of patients receiving Rd in the RMG yielded the lowest AIC for the log-logistic curves in second- and third-line patients, and for the exponential curve in fourth-line patients. For OS, the exponential curve resulted in the lowest AIC in second- and fourth-lines, and for the log-logistic curve in third-line patients. For TTD, the Weibull curve was associated with the lowest AIC in second- and third-lines; the AIC of the Weibull curve in fourth-line patients was very similar to that of the lowest AIC (Gompertz), and for that reason the Weibull function was selected for estimating TTD in all three lines. AIC values for PFS, OS and TTD are reported in the online resources (Supplementary Table 2.7).

The results from the test of interaction between treatment effect and time ( $\mathrm{p}=0.08$ for PFS; $p=0.41$ for OS), and visual examination of the log-cumulative hazard plots suggested that the proportional hazards assumption was valid, as reported by Jakubowiak et al. [32]. The stepwise Cox models showed that there was no evidence of treatment-covariate interaction which, along with the lack of evidence of differences in relative treatment effects across subgroups reported by Stewart et al., supported the assumption that relative treatment effects observed in ASPIRE could be transferable to the RW setting [15,32]. The stepwise Cox models identified a number of baseline covariates with a potential prognostic effect for predicting PFS and OS. For PFS, the following covariates were identified: baseline haemoglobin (higher risk of progression if $<105 \mathrm{~g} / \mathrm{L}$ ), baseline platelet count (higher risk if $<150 \times 109 / \mathrm{L}$ ), baseline calcium level 
(higher risk if $>11.5 \mathrm{mg} / \mathrm{dL}$ ), International Staging System (ISS) stage at diagnosis (higher risk for stage II compared with stage I and missing categories; similar risk for stage II and III patients), $\beta-2$ microglobulin level at stratification (higher risk if $\geq 2.5$ $\mathrm{mg} / \mathrm{L}$ ), risk group as determined by fluorescent in-situ hybridisation (higher risk for high risk patients compared with standard and unknown categories), prior bortezomib exposure (higher risk for patients with prior bortezomib exposure) and refractory to immunomodulatory agents in any prior regimen (higher risk for refractory patients). For OS, the following covariates were identified: sex (higher risk of death for male patients), baseline Eastern Cooperative Oncology Group (ECOG; higher risk for patients with ECOG of 2 compared with patients with ECOG of 1 ; similar risk for patients with values of 0 and 1), baseline haemoglobin (higher risk if $<105 \mathrm{~g} / \mathrm{L}$ ), baseline platelet count (higher risk if $<150 \times 109 / \mathrm{L}$ ), baseline creatinine clearance (continuous variable), disease stage at diagnosis (higher risk for stage II compared with stage I), $\beta-2$ microglobulin level at stratification (higher risk if $\geq 2.5 \mathrm{mg} / \mathrm{L}$ ) and refractory to immunomodulatory agents in any prior regimen (higher risk for refractory patients). The multiple Cox models showed statistically significant treatment effects for both PFS and OS: the PFS HR was equal to 0.641 (95\% CI: 0.526-0.781; p-value $<0.001)$ and OS HR equal to 0.731 (95\% CI: 0.612-0.872; p-value $<0.001)$. Given that the assumption of proportional hazards was considered appropriate, the HRs calculated from these analyses were applied to the PFS, OS (Figure 2.2) and TTD curves of Rd to derive the corresponding KRd curves.

Figure 2.2. Progression-free survival and overall survival curves for Rd and KRd in the base case analysis.

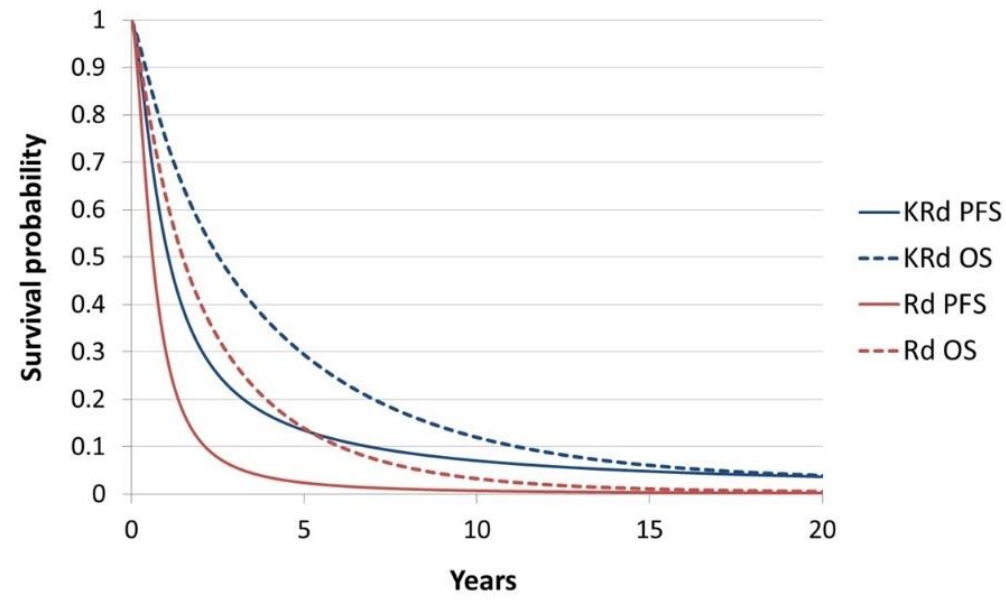

The base case ICER for KRd compared with Rd was $€ 73,156$ per QALY gained (Table 2.5). Patients on KRd incurred costs of $€ 117,534$ over their lifetime compared with $€ 53,165$ for patients on Rd. The QALYs gained were 2.63 and 1.75 for patients on KRd and Rd, respectively; the LY gained were 3.42 and 2.43 for patients on KRd and Rd, 
respectively.

Table 2.5. Base case results.

\begin{tabular}{|l|c|c|c|c|c|c|c|}
\hline & $\begin{array}{c}\text { Total } \\
\text { costs } \\
(\boldsymbol{\epsilon})\end{array}$ & $\begin{array}{c}\text { Total } \\
\text { LYs }\end{array}$ & $\begin{array}{c}\text { Total } \\
\text { QALYs }\end{array}$ & $\begin{array}{c}\text { Incremental } \\
\text { costs }(\boldsymbol{\epsilon})\end{array}$ & $\begin{array}{c}\text { Incremental } \\
\text { LYs }\end{array}$ & $\begin{array}{c}\text { Incremental } \\
\text { QALYs }\end{array}$ & $\begin{array}{c}\text { ICER } \\
\text { (€/QALY) }\end{array}$ \\
\cline { 1 - 4 } Rd & 53,165 & 2.43 & 1.75 & \multirow{2}{*}{64,368} & 0.99 & 0.88 & 73,156 \\
\cline { 1 - 3 } KRd & 117,534 & 3.42 & 2.63 & & & & \\
\hline
\end{tabular}

KRd, carfilzomib/lenalidomide/dexamethasone; ICER, incremental cost-effectiveness ratio; LY, life year; QALYs, qualityadjusted life year; Rd, lenalidomide/dexamethasone.

Table 2.6 shows that the largest proportion of incremental costs is due to the increased treatment costs in the KRd arm. Higher costs of lenalidomide and dexamethasone in the KRd arm are a consequence of extending Rd treatment duration in the KRd arm compared with the Rd arm, due to a better response to treatment in KRd patients that allows patients to remain on therapy for longer. Costs of AEs and monitoring costs are also higher in the KRd arm due to patients staying longer in the PF state, as compared with patients receiving $\mathrm{Rd}$ treatment.

\section{Sensitivity analyses}

Results of univariate DSA are presented in a form of a tornado diagram (Figure 2.3). The ICER was most influenced by the OS HR, followed by the pre-progression utilities, BSA, RDI and the shape parameter of the log-logistic curve for OS in second-line patients. The model results were less sensitive to the TTD estimates and PFS HR. 
Table 2.6. Summary of predicted costs by item.

\begin{tabular}{|l|c|c|c|}
\hline Item & $\begin{array}{c}\text { Cost KRd } \\
(\boldsymbol{€})\end{array}$ & $\begin{array}{c}\text { Cost Rd } \\
(\boldsymbol{\epsilon})\end{array}$ & $\begin{array}{c}\text { Increment } \\
(\boldsymbol{€})\end{array}$ \\
\hline Drug cost: carfilzomib & 56,152 & 0 & 56,152 \\
\hline Drug cost: lenalidomide & 41,273 & 36,069 & 5,204 \\
\hline Drug cost: dexamethasone & 84 & 71 & 13 \\
\hline Administration cost: carfilzomib & 1,414 & 0 & 1,414 \\
\hline Adverse events costs & 270 & 224 & 46 \\
\hline Monitoring costs & 839 & 451 & 388 \\
\hline Subsequent treatments & 1,013 & 1,216 & -203 \\
\hline Administration cost: subsequent treatments & 107 & 128 & -21 \\
\hline Palliative care costs & 16,382 & 15,006 & 1,375 \\
\hline Total & 117,534 & 53,165 & 64,368 \\
\hline
\end{tabular}

KRd, carfilzomib/lenalidomide/dexamethasone; Rd, lenalidomide/dexamethasone.

Figure 2.3. Tornado diagram illustrating the results of the univariate deterministic sensitivity analyses.

ICER

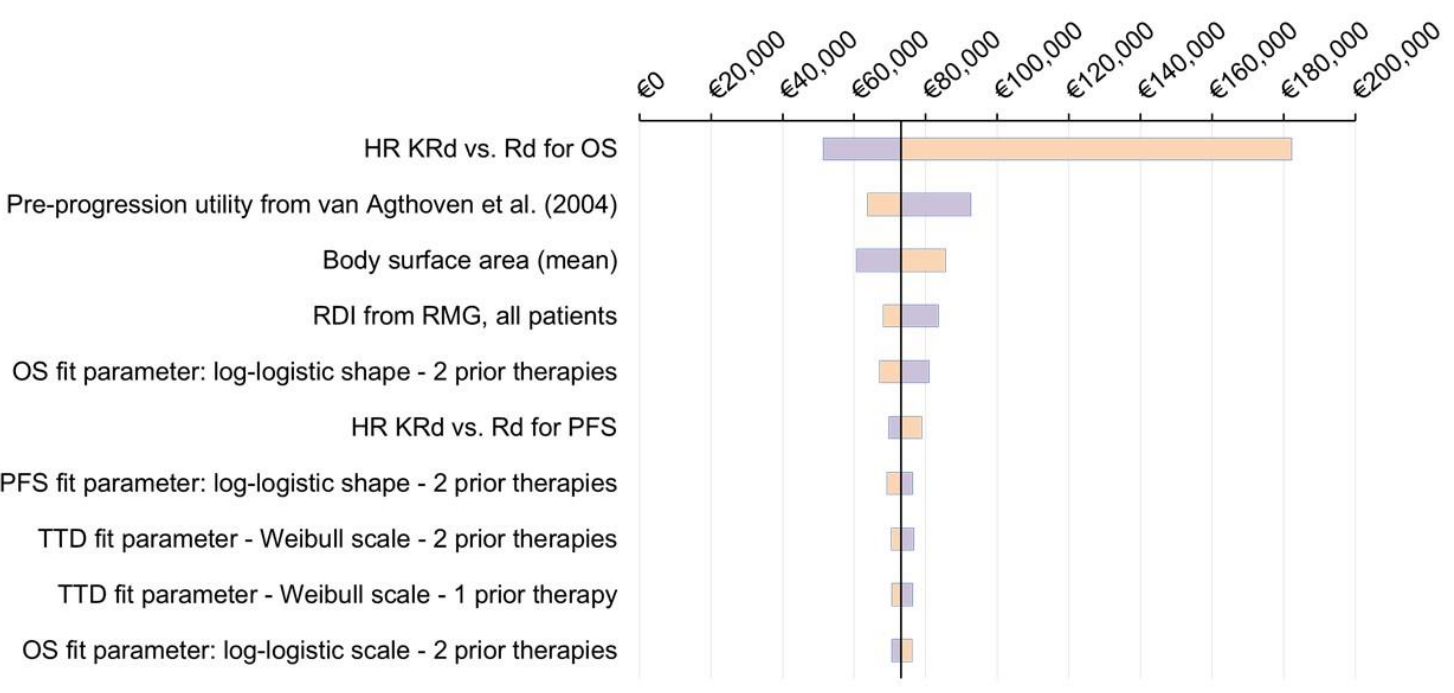

$\square$ Lower bound $\square$ Upper bound 
The results of the PSA are shown in Figure 2.4. The scatter plot of incremental costs and QALYs shows that all simulations resulted in KRd being more effective and more costly than Rd, yielding an ICER very close to the base case ICER (€73,649 per QALY). The cost-effectiveness acceptability curve (Figure 2.5) demonstrates that the probability of KRd being the most-effective intervention was highest at a willingness to pay threshold between $€ 70,000$ and $€ 75,000$ per QALY and above.

Figure 2.4. Incremental cost-effectiveness plane for KRd versus Rd.

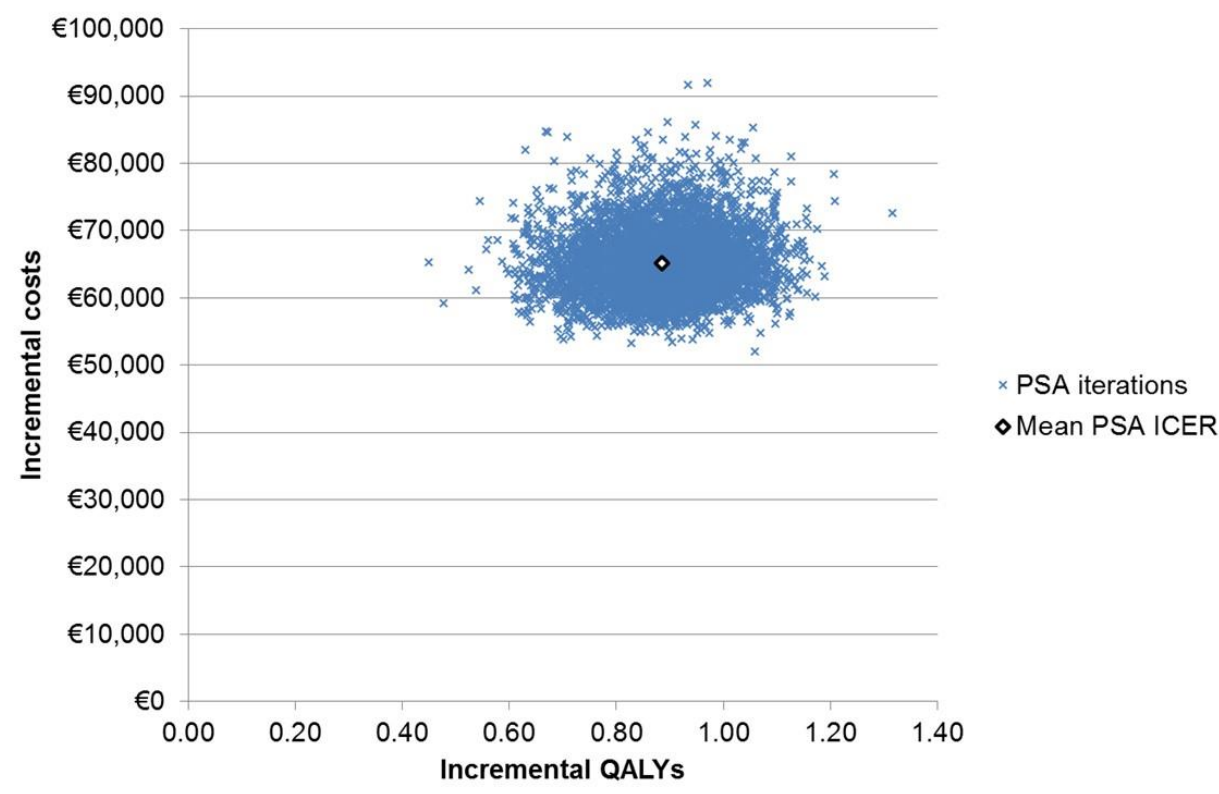

Figure 2.5. Incremental cost-effectiveness acceptability curve for KRd versus Rd.

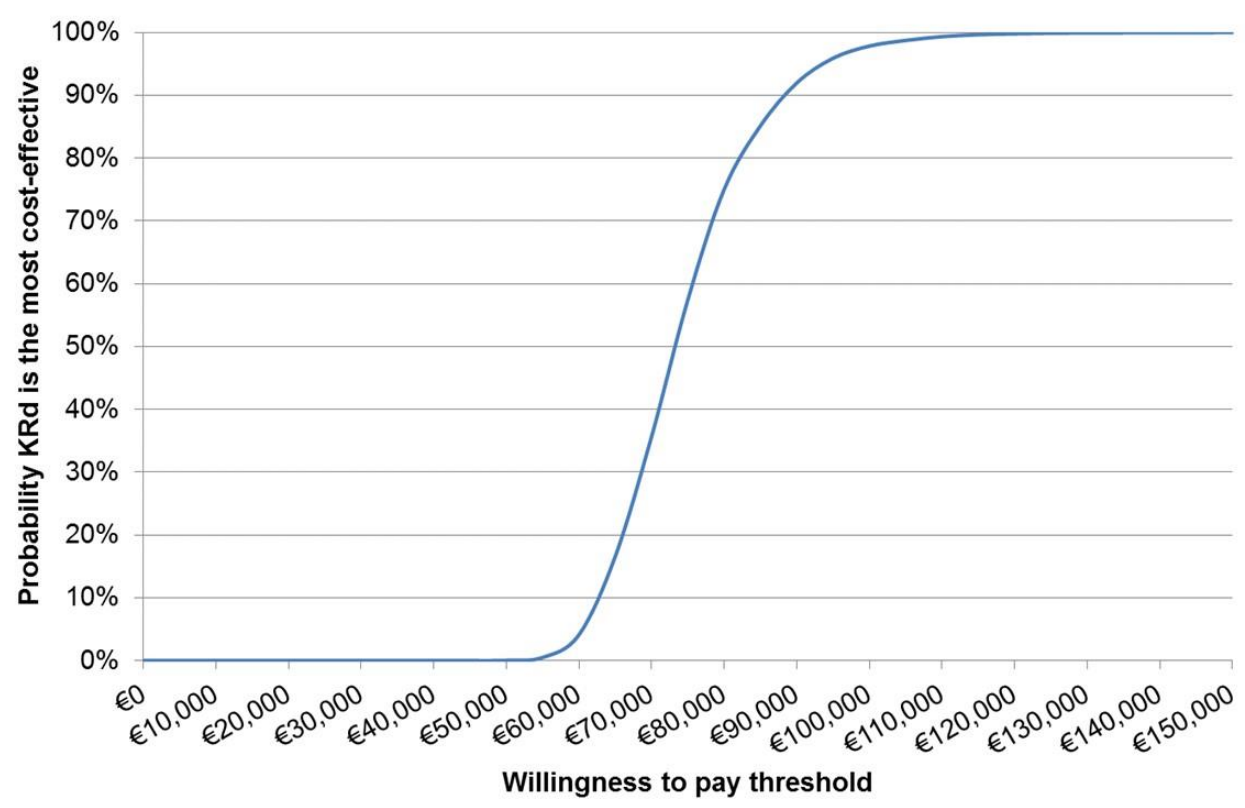


Results from scenario analyses are summarised in Table 2.7. Consideration of carfilzomib costs only resulted in a reduction of the ICER from $€ 73,156$ to $€ 67,347$ per QALY, while the implementation of the unadjusted PFS and OS HRs pushed the ICER up to $€ 93,094$ per QALY. Implementing discount rates of $0 \%$ for costs and outcomes reduced the ICER ( $€ 56,930$ per QALY) compared with the base case, whereas assuming the same utilities for KRd and Rd arms, setting the time horizon at 20 years and assuming discount rates of $5 \%$ increased the ICER ( $€ 77,258, € 80,703$ and $€ 83,807$ per QALY, respectively). 
Table 2.7. Results from scenario analyses.

\begin{tabular}{|c|c|c|c|c|c|c|c|c|c|c|}
\hline \multirow{2}{*}{ Scenario } & \multicolumn{3}{|c|}{ KRd } & \multicolumn{3}{|c|}{ Rd } & \multirow{2}{*}{$\begin{array}{c}\text { Incremental } \\
\text { costs }(€)\end{array}$} & \multirow{2}{*}{$\begin{array}{l}\text { Incremental } \\
\text { LYs }\end{array}$} & \multirow{2}{*}{$\begin{array}{c}\text { Incremental } \\
\text { QALYs }\end{array}$} & \multirow{2}{*}{$\begin{array}{c}\text { ICER } \\
(€ / \text { QALY })\end{array}$} \\
\hline & $\begin{array}{c}\text { Total costs } \\
(€)\end{array}$ & $\begin{array}{l}\text { Total } \\
\text { LYs }\end{array}$ & $\begin{array}{c}\text { Total } \\
\text { QALYs }\end{array}$ & $\begin{array}{c}\text { Total costs } \\
(€)\end{array}$ & $\begin{array}{l}\text { Total } \\
\text { LYs }\end{array}$ & $\begin{array}{c}\text { Total } \\
\text { QALYs }\end{array}$ & & & & \\
\hline Base case & 117,534 & 3.42 & 2.63 & 53,165 & 2.43 & 1.75 & 64,368 & 0.99 & 0.88 & 73,156 \\
\hline Carfilzomib costs only ${ }^{\mathrm{a}}$ & 75,648 & 3.42 & 2.63 & 16,391 & 2.43 & 1.75 & 59,257 & 0.99 & 0.88 & 67,347 \\
\hline $\begin{array}{l}\text { Unadjusted PFS and OS } \\
\mathrm{HRs}^{\mathrm{b}}\end{array}$ & 112,651 & 3.12 & 2.39 & 53,165 & 2.43 & 1.75 & 59,485 & 0.69 & 0.64 & 93,094 \\
\hline $\begin{array}{l}\text { Same utilities for KRd } \\
\text { and } \mathrm{Rd} \operatorname{arms}^{\mathrm{c}}\end{array}$ & 117,534 & 3.42 & 2.63 & 53,165 & 2.43 & 1.80 & 64,368 & 0.99 & 0.83 & 77,258 \\
\hline Time horizon of 20 years & 117,410 & 3.31 & 2.53 & 52,954 & 2.41 & 1.73 & 64,456 & 0.90 & 0.80 & 80,703 \\
\hline $\begin{array}{l}\text { Discount rate of } 0 \% \text { for } \\
\text { both costs and outcomes }\end{array}$ & 121,767 & 3.98 & 3.07 & 55,609 & 2.66 & 1.91 & 66,158 & 1.32 & 1.16 & 56,930 \\
\hline $\begin{array}{l}\text { Discount rate of } 5 \% \text { for } \\
\text { both costs and outcomes }\end{array}$ & 115,126 & 3.16 & 2.42 & 51,871 & 2.31 & 1.67 & 63,255 & 0.84 & 0.75 & 83,807 \\
\hline
\end{tabular}

HR, hazard ratio; ICER, incremental cost-effectiveness ratio; KRd; carfilzomib/lenalidomide/dexamethasone; LY, life year; OS, overall survival; PFS, progression-free survival; QALY,

quality-adjusted life year; Rd, lenalidomide/dexamethasone.

${ }^{a} \mathrm{Rd}$ drug costs were excluded from both KRd and Rd arms.

${ }^{b}$ The PFS HR was obtained from the primary ASPIRE publication. The OS HR from the April 2017 data cut was 0.794 (95\% CI: 0.667-0.945; p-value<0.001).

${ }^{\mathrm{c}}$ Utilities of KRd assumed for both KRd and Rd arms. 


\section{DISCUSSION}

The current analysis evaluated the RW cost-utility of KRd versus Rd in relapsed MM patients that have received one to three prior therapies, resulting in an ICER of $€ 73,156$ per QALY gained in the base case. The cost-utility model developed for the analysis used a partitioned survival modelling approach, which is employed in a significant proportion of economic evaluations of cancer therapies. Scientifically reputable health technology assessment agencies such as NICE have repeatedly reviewed and confirmed the appropriateness of such model structure $[29,30]$. The analysis was conducted from the payer perspective, and the Czech Republic was chosen to illustrate the model given the rich observational data sources available in the country.

For estimating the RW cost-effectiveness of KRd versus Rd, the baseline hazard of patients treated with Rd (PFS, OS and TTD) were calculated from the RMG, one of the most comprehensive and relevant registries capturing outcomes of MM patients [16]. The KRd versus Rd HRs from ASPIRE were applied to the baseline hazard to estimate the hazard of patients receiving KRd in the RW, assuming that the relative treatment effects observed in ASPIRE are applicable in the RW. Results from the phase 3 ASPIRE trial demonstrated that the relative treatment effects are consistent across a wide variety of subgroups of relapsed MM patients, and additional statistical analyses showed no significant treatment-covariate interaction in the ASPIRE patient population [15, 32]. This is regarded as a strong evidence base to support the applicability of trial HRs in the RW [9]. This methodology has been previously adopted for the estimation of RW cost-effectiveness of health technologies in oncology as well as other disease areas, such as cardiovascular and respiratory diseases; $[10,21,22,24-26]$ the approach has also been accepted by NICE, issuing a positive recommendation for evolocumab for treating primary hypercholesterolaemia or mixed dyslipidaemia in specific patient groups based on an economic model that combined baseline risks of cardiovascular disease from the Clinical Practice Research Datalink registry with reductions in cardiovascular events from a meta-analysis of RCTs [58]. 
Neyt et al. argue that combining observational data with evidence from RCTs is a solution for handling potential differences between RW patients and RCT patients: RCTs are the gold standard for estimating relative treatment effects, whereas observational databases capture baseline risks of patients treated in RW conditions, and therefore an analysis that combines the strengths of both observational and RCT data may result in results that are more relevant for policy purposes, compared with results obtained from data collected under ideal circumstances (i.e. RCTs) only. With regard to the current decision problem, the outcomes observed in ASPIRE were substantially better than those observed in the RMG: in ASPIRE, the median PFS and OS were 17.6 and 40.4 months, respectively, for patients receiving $\mathrm{Rd}$; [15,38] patients in the RMG, however, had median PFS and OS values of approximately 7.6 and 19.3 months, respectively (weighted values from Table 2.1). Similar differences were identified for treatment duration: the median TTD was 13.1 months in the Rd arm in ASPIRE, in contrast with the 6.1 months in the RMG (Table 2.1) $[15,38]$. These dissimilarities between ASPIRE and the RMG are likely to arise from differences in patient characteristics, treatment selection and treatment patterns between the trial and the RW. For these reason, and given the available evidence base, the use of registry data to inform baseline risks in economic models is considered to present healthcare managers with the most relevant information package for an appropriate decision-making and avoid unrealistic budget impact predictions caused by overestimating key variables such as treatment duration. This is particularly important in MM where a number of trials that enrolled patients across the world have consistently shown better outcomes and longer treatment duration than what is achieved in the RW [11-15].

The sensitivity analyses showed that the model is particularly sensitive to the parameters predicting and assumptions made around the relative treatment effect for OS associated with KRd versus Rd. However, considering that RW outcomes are not yet available for $\mathrm{KRd}$, the base case is considered to represent a set of plausible assumptions.

In the current model, patients in the KRd arm were estimated to spend longer time in PFS 
compared with patients in the Rd arm, which in turn extended the use of lenalidomide and dexamethasone in the KRd arm (the cost of lenalidomide and dexamethasone was $€ 41,273$ versus $€ 36,069$ in the $\mathrm{KRd}$ and $\mathrm{Rd}$ arms, respectively; Table 2.6). Innovative therapies like carfilzomib tend to extend the use of costly therapies that have been considered costeffective in the past (e.g. lenalidomide given on top of carfilzomib in the KRd regimen), and this could generate the perception that the innovative therapies are more expensive than they actually are $[32,56,57]$. The currently accepted methodology for cost-effectiveness analysis does not consider the new paradigm of oncology regimens administered in combination, which represents a major hurdle to demonstrate cost-effectiveness of innovative therapies. Health technology assessment agencies such as NICE have recognised these challenges and acknowledged that some innovative therapies may not even be costeffective at zero price, but no practical solution has been proposed and widely accepted thus far [59]. For this reasons, one scenario analysis evaluated the cost-effectiveness of carfilzomib excluding the costs of lenalidomide and dexamethasone in both $\mathrm{KRd}$ and $\mathrm{Rd}$ arms, i.e. focusing the analysis on the introduction of carfilzomib only. The ICER was lower than that of the base case $(€ 67,347$ and $€ 73,156$ per QALY in the scenario analysis and base case, respectively), which is in line with the results shown by Jakubowiak et al. [32]. This approach was accepted by NICE in the technology appraisal of cinacalcet, where the costs of dialysis were excluded from the base case analysis $[60,61]$.

In RCTs, it is expected that the randomisation process will produce treatment groups that are balanced across the covariate levels. In reality, however, it is common to observe post hoc imbalances in covariates across treatment groups, which may have a confounding effect. In order to remove the between-patient variability associated with covariates not included as randomisation factors and increase the generalisability of the analyses, as well as allowing for the unbiased transferability to RW data, PFS and OS HRs estimated from ASPIRE were adjusted for a number of baseline covariates [32]. A scenario analysis was conducted to quantify the impact of covariate adjustment on cost-effectiveness results by implementing the unadjusted HRs from ASPIRE, and the ICER increased from $€ 73,156$ to 
$€ 93,094$ per QALY [15]. Nevertheless, the stepwise Cox models conducted on the ASPIRE patient-level data indicated that a number of covariates may have a prognostic effect on PFS and OS, and therefore the base case ICER is considered to be more precise and relevant for decision-making purposes.

Additional scenario analyses demonstrated the robustness of the model results. The assumption of equal utilities in the $\mathrm{KRd}$ and $\mathrm{Rd}$ arms, which represents a conservative assumption as described by Jakubowiak et al., only increased the ICER to €77,258 per QALY, and a similar effect on the ICER was observed when shortening the time horizon to 20 years ( $€ 80,703$ per QALY) or setting the discount rate of both costs and outcomes at $5 \%$ (ICER of $€ 83,807$ per QALY). On the other hand, assuming a discount rate of $0 \%$ improved the cost-effectiveness of KRd considerably, yielding an ICER of $€ 56,930$ per QALY.

The analysis had various limitations associated with the underlying data and methods. Firstly, the review of the literature to identify some input parameters for the costeffectiveness model was not systematic. All inputs were, however, obtained from relevant data sources (either from the pivotal clinical trial ASPIRE or local data sources in the Czech Republic) and therefore it is considered that the impact of not having conducted a systematic literature review for all input parameters is minimal. This strategy is aligned with other RW CE studies in the literature $[10,21,22,62]$. The PFS, OS and TTD curves were derived from data collected during a period in which, in the Czech Republic, patients were treated with lenalidomide only up to a maximum cumulative dose of 4,200 $\mathrm{mg}$ [56]. The model, however, assumed that patients would be treated with lenalidomide until progression, in line with the most recent decision in October 2016 by SÚKL on lenalidomide reimbursement, and costs of lenalidomide and dexamethasone were implemented accordingly [57]. The outcomes that would have been observed if lenalidomide and dexamethasone had been given until progression may have been better than those captured in the RMG and used in the current model, and therefore the outcomes generated in the current model may be an underestimation. On the other hand, no hard stop 
at eight cycles (i.e. equivalent to a cumulative dose of $4,200 \mathrm{mg}$ assuming no dose reductions and no missed doses) or any time point afterwards was observed in the TTD curves from the RMG, indicating that the impact of the 4,200 mg cap may not be sizable. With regard to AE rates, the model included rates estimated from the ASPIRE frequencies of AEs. No data on AEs were available from the RMG and therefore no further adjustment was conducted. This represents a further limitation, although the impact of AE costs on the cost-effectiveness of KRd is minimal (i.e. the incremental cost of AEs is only $0.07 \%$ of the total incremental costs of KRd compared with Rd; see Table 2.6). The last PFS and OS events in patients captured in the RMG happened at nearly five years; the KM estimates showed a probability of remaining progression-free of approximately $5 \%$ and a probability of survival of approximately $20 \%$ at about five years (see online resources; Supplementary Figure 2.1 and 2.2). The long-term extrapolation of PFS and OS may be seen as a key contributor to the model uncertainty particularly considering the extent of the time horizon in the base case but, taking into account the maturity of the RMG data, this long-term extrapolation is not deemed to have a large impact on results. Besides, in a recent retrospective analysis of long-term PFS and OS data of Rd patients in the RMG registry, the median PFS and OS was estimated to be 9.0 months and 18.5 months, respectively [62]. PFS and OS at six years was $<5 \%$ and $20 \%$, respectively. These values are very closely in line with the predictions of our model therefore we believe the PFS and OS predictions can be considered valid. Additionally, a scenario analysis looked into the impact of shortening the time horizon to 20 years, and demonstrated that the choice of time horizon does not have a large impact on the cost-effectiveness results. Other limitations, such as the uncertainty around the utility estimates, have been discussed by Jakubowiak et al. [32].

The cost-effectiveness analysis by Jakubowiak et al. compared KRd versus Rd in relapsed MM from a US perspective, with an ICER of \$107,520 per QALY [32]. The authors estimated that patients treated with KRd would benefit from 1.99 incremental LYs and 1.67 incremental QALYs compared with Rd, in contrast with the incremental 0.99 LYs and 0.88 QALYs estimated in the current model [32]. Larger differences can be observed when 
absolute LYs and QALY estimates are compared, despite the similar relative improvement in LYs and QALYs between the two analyses [32]. This reinforces the value of using RW data in cost-effectiveness analyses to avoid estimations that diverge from observed outcomes in the RW. However, these seemingly disparate results can be primarily explained by one key difference in the modelling approach between the two models: the data source used for calculating the PFS, OS and TTD curves. Jakubowiak et al. derived these curves for both KRd and Rd arms by fitting joint parametric models to the ASPIRE trial data; registry data (collected from the US Surveillance, Epidemiology, and End Results registry) were only used for the extrapolation of the Rd OS curve after the time of the last death event in the Rd arm in ASPIRE, and the OS HR was then used to estimate the corresponding OS curve for patients in the KRd arm.

In summary, this analysis showed that cost-effectiveness models of health technologies in the RW can generate policy-relevant results when the strengths of both RCTs and powerful observational databases are combined. The current model showed that KRd is likely to be cost-effective versus $\mathrm{Rd}$ in the RW population (MM patients with one to three prior therapies), with an ICER of $€ 73,156$ per QALY and these results, along with the costeffectiveness analysis conducted by Jakubowiak et al., confirm that KRd is likely to be costeffective versus Rd both in the clinical and RW settings [32]. Therefore, the reimbursement of KRd for this patient population represents an efficient allocation of resources within the healthcare system. 


\section{REFERENCES}

1. American Society of Clinical Oncology (ASCO): Multiple Myeloma: Statistics. https://www.cancer.net/cancer-types/multiplemyeloma/statistics (2016). Accessed November 22nd 2017

2. Barlogie, B., Mitchell, A., van Rhee, F., Epstein, J., Morgan, G.J., Crowley, J.: Curing myeloma at last: defining criteria and providing the evidence. Blood 124(20), 3043-3051 (2014). doi:10.1182/blood-2014-07-552059

3. Ferlay, J., Soerjomataram, I., Dikshit, R., Eser, S., Mathers, C., Rebelo, M., Parkin, D.M., Forman, D., Bray, F.: Cancer incidence and mortality worldwide: sources, methods and major patterns in GLOBOCAN 2012. International journal of cancer 136(5), E359-386 (2015). doi:10.1002/ijc.29210

4. Laudicella, M., Walsh, B., Burns, E., Smith, P.C.: Cost of care for cancer patients in England: evidence from population-based patient-level data. British journal of cancer 114(11), 1286-1292 (2016). doi:10.1038/bjc.2016.77

5. National Cancer Institute's Division of Cancer Control and Population Sciences: Surveillance, Epidemiology, and End Results Program. Cancer Stat Facts: Myeloma. https://seer.cancer.gov/statfacts/html/mulmy.html.

6. Sullivan, R., Peppercorn, J., Sikora, K., Zalcberg, J., Meropol, N.J., Amir, E., Khayat, D., Boyle, P., Autier, P., Tannock, I.F., Fojo, T., Siderov, J., Williamson, S., Camporesi, S., McVie, J.G., Purushotham, A.D., Naredi, P., Eggermont, A., Brennan, M.F., Steinberg, M.L., De Ridder, M., McCloskey, S.A., Verellen, D., Roberts, T., Storme, G., Hicks, R.J., Ell, P.J., Hirsch, B.R., Carbone, D.P., Schulman, K.A., Catchpole, P., Taylor, D., Geissler, J., Brinker, N.G., Meltzer, D., Kerr, D., Aapro, M.: Delivering affordable cancer care in high-income countries. The Lancet. Oncology 12(10), 933-980 (2011). doi:10.1016/s1470-

2045(11)70141-3

7. Chen, Y., Lairson, D.R., Chan, W., Huo, J., Du, X.L.: Cost-Effectiveness of Novel Agents in Medicare Patients with Multiple Myeloma: Findings from a U.S. Payer's Perspective. Journal of managed care \& specialty pharmacy 23(8), 831-843 (2017). doi:10.18553/jmcp.2017.23.8.831

8. Mullins, C.D., Montgomery, R., Tunis, S.: Uncertainty in assessing value of oncology treatments. The oncologist 15 Suppl 1 , 58-64 (2010). doi:10.1634/theoncologist.2010-S1-58

9. Neyt, M., Cleemput, I., Thiry, N., De Laet, C.: Calculating an intervention's (cost-)effectiveness for the real-world target population: the potential of combining strengths of both RCTs and observational data. Health policy (Amsterdam, Netherlands) 106(2), 207-210 (2012). doi:10.1016/j.healthpol.2012.04.014

10. van Gils, C.W., de Groot, S., Redekop, W.K., Koopman, M., Punt, C.J., Uyl-de Groot, C.A.: Real-world cost-effectiveness of oxaliplatin in stage III colon cancer: a synthesis of clinical trial and daily practice evidence. PharmacoEconomics 31(8), 703-718 (2013). doi:10.1007/s40273-013-0061-6

11. Dimopoulos, M.A., Oriol, A., Nahi, H., San-Miguel, J., Bahlis, N.J., Usmani, S.Z., Rabin, N., Orlowski, R.Z., Komarnicki, M., Suzuki, K., Plesner, T., Yoon, S.S., Ben Yehuda, D., Richardson, P.G., Goldschmidt, H., Reece, D., Lisby, S., Khokhar, N.Z., 
O'Rourke, L., Chiu, C., Qin, X., Guckert, M., Ahmadi, T., Moreau, P.: Daratumumab, Lenalidomide, and Dexamethasone for Multiple Myeloma. The New England journal of medicine 375(14), 1319-1331 (2016). doi:10.1056/NEJMoa1607751

12. Hajek, R., Jarkovsky, J., Campioni, M., DeCosta, L., Treur, M., Gonzalez-McQuire, S., Bouwmeester, W.: Long-term Outcomes and Treatment Patterns in Patients with Symptomatic Multiple Myeloma in the Real-world Setting: a Retrospective Analysis of the Czech RMG Registry. PCN136. Paper presented at the International Society for Pharmacoeconomics and Outcomes Research 21st Annual Meeting, Washington, DC, US, 21-25 May, 2016

13. Lonial, S., Dimopoulos, M., Palumbo, A., White, D., Grosicki, S., Spicka, I., Walter-Croneck, A., Moreau, P., Mateos, M.V., Magen, H., Belch, A., Reece, D., Beksac, M., Spencer, A., Oakervee, H., Orlowski, R.Z., Taniwaki, M., Rollig, C., Einsele, H., Wu, K.L., Singhal, A., San-Miguel, J., Matsumoto, M., Katz, J., Bleickardt, E., Poulart, V., Anderson, K.C., Richardson, P.: Elotuzumab Therapy for Relapsed or Refractory Multiple Myeloma. The New England journal of medicine 373(7), 621-631 (2015). doi:10.1056/NEJMoa1505654

14. Moreau, P., Masszi, T., Grzasko, N., Bahlis, N.J., Hansson, M., Pour, L., Sandhu, I., Ganly, P., Baker, B.W., Jackson, S.R., Stoppa, A.M., Simpson, D.R., Gimsing, P., Palumbo, A., Garderet, L., Cavo, M., Kumar, S., Touzeau, C., Buadi, F.K., Laubach, J.P., Berg, D.T., Lin, J., Di Bacco, A., Hui, A.M., van de Velde, H., Richardson, P.G.: Oral Ixazomib, Lenalidomide, and

Dexamethasone for Multiple Myeloma. The New England journal of medicine 374(17), 1621-1634 (2016).

doi:10.1056/NEJMoa1516282

15. Stewart, A.K., Rajkumar, S.V., Dimopoulos, M.A., Masszi, T., Spicka, I., Oriol, A., Hajek, R., Rosinol, L., Siegel, D.S., Mihaylov, G.G., Goranova-Marinova, V., Rajnics, P., Suvorov, A., Niesvizky, R., Jakubowiak, A.J., San-Miguel, J.F., Ludwig, H., Wang, M., Maisnar, V., Minarik, J., Bensinger, W.I., Mateos, M.V., Ben-Yehuda, D., Kukreti, V., Zojwalla, N., Tonda, M.E., Yang, X., Xing, B., Moreau, P., Palumbo, A.: Carfilzomib, lenalidomide, and dexamethasone for relapsed multiple myeloma. The New England journal of medicine 372(2), 142-152 (2015). doi:10.1056/NEJMoa1411321

16. Radocha, J., Pour, L., Spicka, I., Scudla, V., Gregora, E., Frankova, H., Hajek, R., Schutzova, M., Sykora, M., Kessler, P., Adamova, D., Wrobel, M., Sedlarikova, L., Sevcikova, S., Horinek, D., Pelcova, J., Brozova, L., Jarkovsky, J., Maisnar, V.: Registry of Monoclonal Gammopathies (RMG) in the Czech Republic. Blood 126(23), 5414 (2015).

17. Grieve, R., Hawkins, N., Pennington, M.: Extrapolation of survival data in cost-effectiveness analyses: improving the current state of play. Medical decision making : an international journal of the Society for Medical Decision Making 33(6), 740-742 (2013). doi:10.1177/0272989x13492018

18. Jackson, C., Stevens, J., Ren, S., Latimer, N., Bojke, L., Manca, A., Sharples, L.: Extrapolating Survival from Randomized Trials Using External Data: A Review of Methods. Medical decision making : an international journal of the Society for Medical Decision Making 37(4), 377-390 (2017). doi:10.1177/0272989x16639900

19. Guyot, P., Ades, A.E., Beasley, M., Lueza, B., Pignon, J.P., Welton, N.J.: Extrapolation of Survival Curves from Cancer Trials Using External Information. Medical decision making : an international journal of the Society for Medical Decision Making 
37(4), 353-366 (2017). doi:10.1177/0272989x16670604

20. Latimer, N.R.: Survival analysis for economic evaluations alongside clinical trials--extrapolation with patient-level data: inconsistencies, limitations, and a practical guide. Medical decision making : an international journal of the Society for Medical Decision Making 33(6), 743-754 (2013). doi:10.1177/0272989x12472398

21. Seferina, S.C., Lobbezoo, D.J., de Boer, M., Dercksen, M.W., van den Berkmortel, F., van Kampen, R.J., van de Wouw, A.J., de Vries, B., Joore, M.A., Peer, P.G., Voogd, A.C., Tjan-Heijnen, V.C.: Real-Life Use and Effectiveness of Adjuvant Trastuzumab in Early Breast Cancer Patients: A Study of the Southeast Netherlands Breast Cancer Consortium. The oncologist 20(8), 856-863 (2015). doi:10.1634/theoncologist.2015-0006

22. Seferina, S.C., Ramaekers, B.L., de Boer, M., Dercksen, M.W., van den Berkmortel, F., van Kampen, R.J., van de Wouw, A.J., Voogd, A.C., Tjan Heijnen, V.C., Joore, M.A.: Cost and cost-effectiveness of adjuvant trastuzumab in the real world setting: A study of the Southeast Netherlands Breast Cancer Consortium. Oncotarget (2017). doi:10.18632/oncotarget.16985

23. Neyt, M., Devriese, S., Thiry, N., Van den Bruel, A.: Tiotropium's cost-effectiveness for the treatment of COPD: a cost-utility analysis under real-world conditions. BMC pulmonary medicine 10, 47 (2010). doi:10.1186/1471-2466-10-47

24. van Kampen, R.J.W., Ramaekers, B.L.T., Lobbezoo, D.J.A., de Boer, M., Dercksen, M.W., van den Berkmortel, F., Smilde, T.J., van de Wouw, A.J., Peters, F.P.J., van Riel, J.M.G., Peters, N., Tjan-Heijnen, V.C.G., Joore, M.A.: Real-world and trial-based cost-effectiveness analysis of bevacizumab in HER2-negative metastatic breast cancer patients: a study of the Southeast Netherlands Breast Cancer Consortium. European journal of cancer (Oxford, England : 1990) 79, 238-246 (2017). doi:10.1016/j.ejca.2017.01.027

25. Fonarow, G.C., Keech, A.C., Pedersen, T.R., Giugliano, R.P., Sever, P.S., Lindgren, P., van Hout, B., Villa, G., Qian, Y., Somaratne, R., Sabatine, M.S.: Cost-effectiveness of Evolocumab Therapy for Reducing Cardiovascular Events in Patients With Atherosclerotic Cardiovascular Disease. JAMA cardiology 2(10), 1069-1078 (2017). doi:10.1001/jamacardio.2017.2762 26. Toth, P.P., Danese, M., Villa, G., Qian, Y., Beaubrun, A., Lira, A., Jansen, J.P.: Estimated burden of cardiovascular disease and value-based price range for evolocumab in a high-risk, secondary-prevention population in the US payer context. Journal of medical economics 20(6), 555-564 (2017). doi:10.1080/13696998.2017.1284078

27. National Institute for Health and Care Excellence: Multiple myeloma - lenalidomide (post bortezomib) (part rev TA171) [ID667]. http://www.nice.org.uk/guidance/indevelopment/gid-tag452/documents (2014). Accessed January 22nd 2018 28. Hornberger, J., Rickert, J., Dhawan, R., Liwing, J., Aschan, J., Lothgren, M.: The cost-effectiveness of bortezomib in relapsed/refractory multiple myeloma: Swedish perspective. European journal of haematology 85(6), 484-491 (2010). doi:10.1111/j.1600-0609.2010.01526.x

29. National Institute for Health and Care Excellence: Pomalidomide for relapsed and refractory multiple myeloma previously treated with lenalidomide and bortezomib. Technology appraisal guidance [TA338]. https://www.nice.org.uk/guidance/ta338 (2015). Accessed January 23rd 2018 
30. National Institute for Health and Care Excellence: Panobinostat for treating multiple myeloma after at least 2 previous treatments. Technology appraisal guidance [TA380]. https://www.nice.org.uk/guidance/ta380/history (2016). Accessed January 23 rd 2018

31. Usmani, S.Z., Cavenagh, J.D., Belch, A.R., Hulin, C., Basu, S., White, D., Nooka, A., Ervin-Haynes, A., Yiu, W., Nagarwala, Y., Berger, A., Pelligra, C.G., Guo, S., Binder, G., Gibson, C.J., Facon, T.: Cost-effectiveness of lenalidomide plus dexamethasone vs. bortezomib plus melphalan and prednisone in transplant-ineligible U.S. patients with newly-diagnosed multiple myeloma. Journal of medical economics 19(3), 243-258 (2016). doi:10.3111/13696998.2015.1115407

32. Jakubowiak, A.J., Campioni, M., Benedict, A., Houisse, I., Tichy, E., Giannopoulou, A., Aggarwal, S.K., Barber, B.L.,

Panjabi, S.: Cost-effectiveness of adding carfilzomib to lenalidomide and dexamethasone in relapsed multiple myeloma from a US perspective. Journal of medical economics 19(11), 1061-1074 (2016). doi:10.1080/13696998.2016.1194278

33. Jakubowiak, A.J., Houisse, I., Majer, I., Benedict, A., Campioni, M., Panjabi, S., Ailawadhi, S.: Cost-effectiveness of carfilzomib plus dexamethasone compared with bortezomib plus dexamethasone for patients with relapsed or refractory multiple myeloma in the United States. Expert review of hematology 10(12), 1107-1119 (2017). doi:10.1080/17474086.2017.1391088 34. Amgen, Data on File.Treatment utilization: a retrospective analysis of the Czech RMG registry. 2018.

35. European Medicines Agency: Kyprolis. Summary of Product Characteristics.

http://www.ema.europa.eu/docs/en_GB/document_library/EPAR_-_Product_Information/human/003790/WC500197692.pdf. Accessed August 4th 2017

36. Státní Ústav Pro Kontrolu Léčiv: Správní řízení. sp. zn. SUKLS157419/2013 (LP Velcade). https://verso.sukl.cz/fcgi/verso.fpl?fname=vp_fspis (2013). Accessed December 12th 2017

37. European Medicines Agency: Revlimid. Summary of Product Characteristics.

http://www.ema.europa.eu/docs/en_GB/document_library/EPAR_-_Product_Information/human/000717/WC500056018.pdf. Accessed August 4th 2017

38. Stewart, A.K., Siegel, D.S., Ludwig, H., Facon, T., Goldschmidt, H., Jakubowiak, A.J., San-Miguel, J.F., Obreja, M., Blaedel, J., Dimopoulos, M.A.: 743 Overal Survival (OS) of Patients with Relapsed/Refractory Multiple Myeloma (RRMM) Treated with Carfilzomib, Lenalidomide, and Dexamethasone (KRd) Versus Lenalidomide and Dexamethasone (Rd): Final Analysis from the Randomized Phase 3 Aspire Trial. Paper presented at the American Society of Hematology (ASH). 59th Annual Meeting \& Exposition, Atlanta, GA. December 9-12, 2017,

39. Ng'andu, N.H.: An empirical comparison of statistical tests for assessing the proportional hazards assumption of Cox's model. Statistics in medicine 16(6), 611-626 (1997).

40. Willan, A.R., Briggs, A.H.: Statistical Analysis of Cost-Effectiveness Data. 2006.

41. European Central Bank: Czech koruna (CZK).

https://www.ecb.europa.eu/stats/policy_and_exchange_rates/euro_reference_exchange_rates/html/eurofxref-graph-czk.en.html 
(2017). Accessed December 11th 2017

42. Státní Ústav Pro Kontrolu Léčiv: List of reimbursed medicinal products valid as of 1.12.2017. http://www.suk1.eu/sukl/list-ofreimbursed-medicinal-products-valid-as-of-1-12-2017 (2017). Accessed December 12th 2017

43. Chirivella, I., Bermejo, B., Insa, A., Perez-Fidalgo, A., Magro, A., Rosello, S., Garcia-Garre, E., Martin, P., Bosch, A., Lluch, A.: Optimal delivery of anthracycline-based chemotherapy in the adjuvant setting improves outcome of breast cancer patients. Breast cancer research and treatment 114(3), 479-484 (2009). doi:10.1007/s10549-008-0018-1

44. Delea, T.E., Amdahl, J., Chit, A., Amonkar, M.M.: Cost-effectiveness of lapatinib plus letrozole in her2-positive, hormone receptor-positive metastatic breast cancer in Canada. Current oncology (Toronto, Ont.) 20(5), e371-387 (2013). doi:10.3747/co.20.1394

45. Fust, K., Li, X., Maschio, M., Villa, G., Parthan, A., Barron, R., Weinstein, M.C., Somers, L., Hoefkens, C., Lyman, G.H.: Cost-Effectiveness Analysis of Prophylaxis Treatment Strategies to Reduce the Incidence of Febrile Neutropenia in Patients with Early-Stage Breast Cancer or Non-Hodgkin Lymphoma. PharmacoEconomics 35(4), 425-438 (2017). doi:10.1007/s40273-0160474-0

46. Hryniuk, W.M., Goodyear, M.: The calculation of received dose intensity. Journal of clinical oncology : official journal of the American Society of Clinical Oncology 8(12), 1935-1937 (1990). doi:10.1200/jco.1990.8.12.1935

47. Vavra, K.L., Saadeh, C.E., Rosen, A.L., Uptigrove, C.E., Srkalovic, G.: Improving the relative dose intensity of systemic chemotherapy in a community-based outpatient cancer center. Journal of oncology practice 9(5), e203-211 (2013).

doi:10.1200/jop.2012.000810

48. Czech Myeloma Group: Czech Myeloma Group guidelines for the treatment of multiple myeloma.

http://www.myeloma.cz/index.php?pg=mnohocetny-myelom--guidelines (2017).

49. Ministerstvo vnitra: Vyhláška č. 421/2016 Sb., kterou se mění vyhláška Ministerstva zdravotnictví č. 134/1998 Sb., kterou se vydává seznam zdravotních výkonů s bodovými hodnotami, ve znění pozdějších předpisů. https://szv.mzcr.cz/Vyhlaska. Accessed December 12th 2017

50. Všeobecná zdravotní pojištovna České republiky (VZP ČR): Číselník 984.

https://www.vzp.cz/poskytovatele/ciselniky/individualne-pripravovane-lecive-pripravky-a-vyrobky-transfuznich-stanic-aradiofarmaka/archiv. Accessed December 12th 2017

51. Novartis: Panobinostat for treating multiple myeloma in people who have received at least one prior therapy. ID663 Single technology appraisal (STA) manufacturer's submission. http://www.nice.org.uk/guidance/indevelopment/gid-tag477/documents (2015). Accessed November 15 th 2015

52. Státní Ústav Pro Kontrolu Léčiv: Správní řízení. sp. zn. SUKLS58379/2014 (LP Imnovid). https://verso.sukl.cz/fcgi/verso.fpl?fname=vp_fspis (2014). Accessed December 12th 2017

53. Ministerstvo zdravotnictví: Metodické materiály pro rok 2017. Materiály dle Sdělení ČSÚ č. 313/2016 Sb., o aktualizaci 
Klasifikace hospitalizovaných (IR-DRG). http://www.mzcr.cz/Odbornik/dokumenty/metodicke-materialy-pro-rok-

2017_12858_1058_3.html. Accessed October 10th 2017

54. Státní Ústav Pro Kontrolu Léčiv: Postup pro posuzování analýzy nákladové efektivity (SP-CAU-028-W).

http://www.sukl.cz/file/85788_1_1 (2017). Accessed December 12th 2017

55. Brown, R.E., Stern, S., Dhanasiri, S., Schey, S.: Lenalidomide for multiple myeloma: cost-effectiveness in patients with one prior therapy in England and Wales. The European journal of health economics : HEPAC : health economics in prevention and care 14(3), 507-514 (2013). doi:10.1007/s10198-012-0395-6

56. Státní Ústav Pro Kontrolu Léčiv: Správní řízení. sp. zn. SUKLS4024/2008 (LP Revlimid 25 mg).

https://verso.sukl.cz/fcgi/verso.fpl?fname=vp_fspis (2008). Accessed December 12th 2017

57. Státní Ústav Pro Kontrolu Léčiv: Správní řízení. sp. zn. SUKLS109735/2014 (LP Revlimid).

https://verso.sukl.cz/fcgi/verso.fpl?fname=vp_fspis (2014). Accessed December 12th 2017

58. National Institute for Health and Care Excellence: Evolocumab for treating primary hypercholesterolaemia and mixed dyslipidaemia. Technology appraisal guidance [TA394]. https:/www.nice.org.uk/guidance/ta394/chapter/1-Recommendations (2016). Accessed December 13th 2017

59. Davis, S.: NICE Decision Support Unit Methods Development. In: Assessing Technologies That Are Not Cost-Effective at a Zero Price. National Institute for Health and Care Excellence (NICE), London (2014)

60. Grima, D.T., Bernard, L.M., Dunn, E.S., McFarlane, P.A., Mendelssohn, D.C.: Cost-effectiveness analysis of therapies for chronic kidney disease patients on dialysis: a case for excluding dialysis costs. PharmacoEconomics 30(11), 981-989 (2012). doi:10.2165/11599390-000000000-00000

61. National Institute for Health and Care Excellence: Cinacalcet for the treatment of secondary hyperparathyroidism in patients with end-stage renal disease on maintenance dialysis therapy. Technology appraisal guidance [TA117].

https://www.nice.org.uk/guidance/ta117/chapter/4-Evidence-and-interpretation\#cost-effectiveness (2007). Accessed January 22nd 2018

62. Maisnar V, Stefanikova Z, Spicka I, Pour L, Minarik J, Flochova E, et al. Lenalidomide and dexamethasone in treatment of patients with relapsed and refractory multiple myeloma - analysis of data from the Czech Myeloma Group Registry of Monoclonal Gammopathies. Neoplasma. 2019. 


\section{SUPPLEMENTARY MATERIAL}

\section{Supplementary Figure 2.1. Progression-free survival curves of patients receiving Rd}

in the RMG.

a

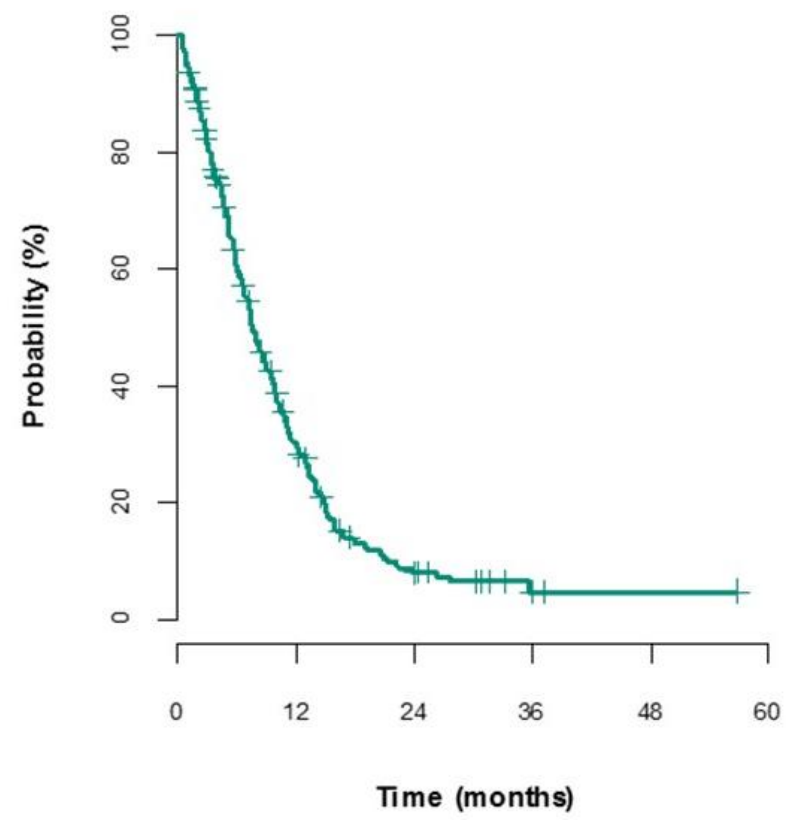

b

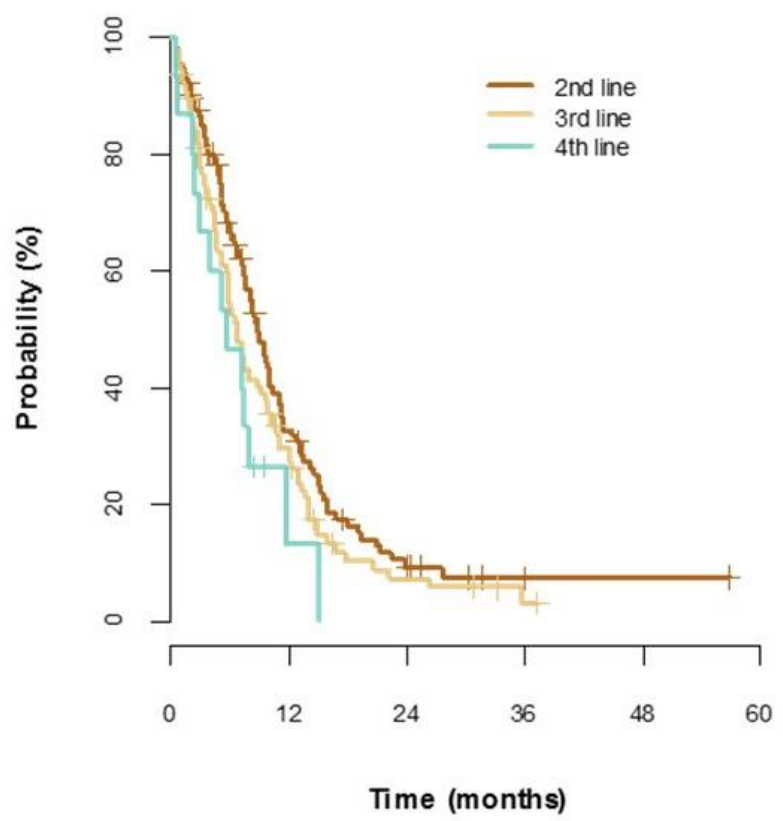

Rd, lenalidomide/dexamethasone; RMG, Registry of Monoclonal Gammopathies.

a) Progression-free survival of all patients with one to three prior lines.

b) Progression-free survival of patients, per treatment line. 


\section{Supplementary Figure 2.2. Overall survival curves of patients receiving $R d$ in the RMG.}

a

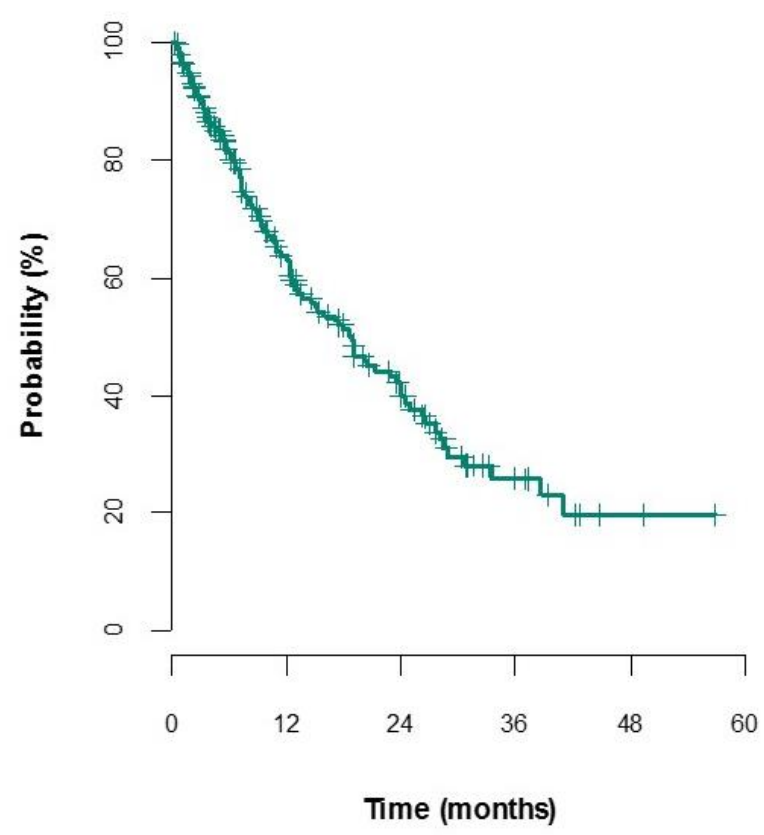

b

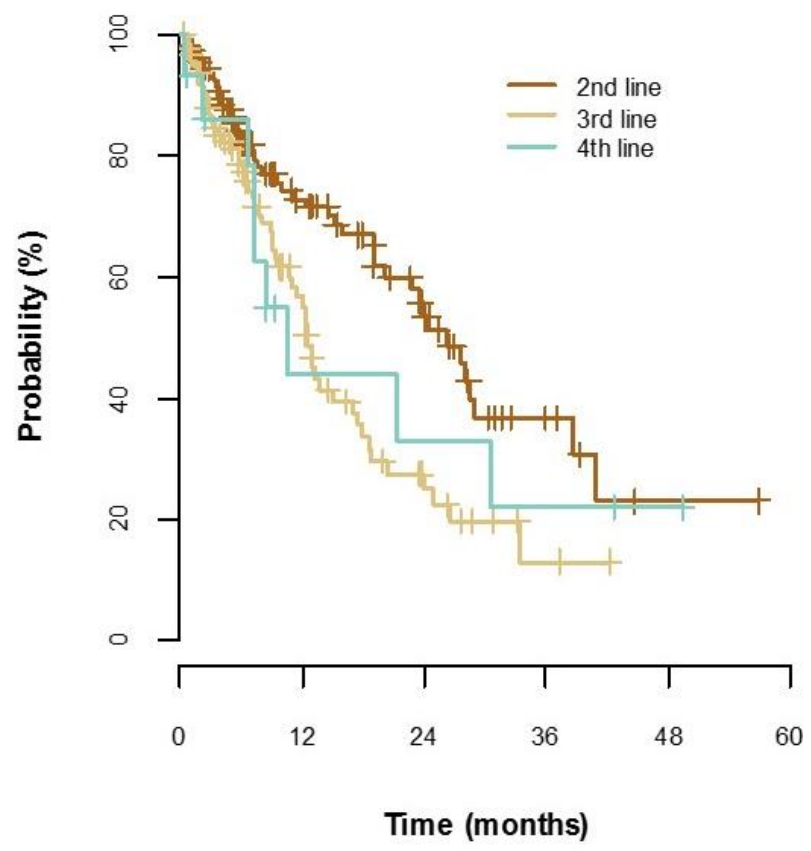

Rd, lenalidomide/dexamethasone; RMG, Registry of Monoclonal Gammopathies.

a) Overall survival of all patients with one to three prior lines.

b) Overall survival of patients, per treatment line. 
Supplementary Table 2.1. Comparison of baseline characteristics in RMG and ASPIRE patients.

\begin{tabular}{|c|c|c|c|}
\hline Descriptive statistics & $\begin{array}{c}\text { Second Line } \\
\text { RMG / ASPIRE } \\
(\mathbf{n}=\mathbf{1 1 3} / \mathbf{n}=157)\end{array}$ & $\begin{array}{c}\text { Third Line } \\
\text { RMG / ASPIRE } \\
(\mathrm{n}=96 / \mathrm{n}=139)\end{array}$ & $\begin{array}{c}\text { Fourth Line } \\
\text { RMG / ASPIRE } \\
(\mathbf{n}=15 / \mathbf{n}=100)\end{array}$ \\
\hline Age (median years) & $69 / 66$ & $66 / 64$ & $76 / 65$ \\
\hline Sex (n, \% male) & $47.8 \% / 51.6 \%$ & $52.1 \% / 69.1 \%$ & $40.0 \% / 55.0 \%$ \\
\hline $\begin{array}{l}\text { Status Performance (ECOG/WHO) } \\
0 \\
1 \\
2 \\
3 \\
4\end{array}$ & $\begin{array}{c}8.2 \% / 38.9 \% \\
60.9 \% / 53.5 \% \\
21.8 \% / 7.6 \% \\
7.3 \% /- \\
1.8 \% /-\end{array}$ & $\begin{array}{c}6.5 \% / 51.1 \% \\
70.7 \% / 40.3 \% \\
18.5 \% / 8.6 \% \\
4.3 \% /- \\
0.0 \% /-\end{array}$ & $\begin{array}{c}6.7 \% \text { / 43.0\% } \\
53.3 \% \text { / 46.0\% } \\
40.0 \% / 11.0 \% \\
0.0 \% \text { / - } \\
0.0 \% \text { - - }\end{array}$ \\
\hline $\begin{array}{l}\text { Beta2 microglobulin }(\mathrm{mg} / \mathrm{l}) \\
<2.5 \\
\geq 2.5\end{array}$ & $\begin{array}{l}17.8 \% / 15.3 \% \\
82.2 \% / 82.8 \%\end{array}$ & $\begin{array}{l}19.7 \% / 24.5 \% \\
80.3 \% / 74.8 \%\end{array}$ & $\begin{array}{l}25.0 \% / 85.0 \% \\
75.0 \% / 13.0 \%\end{array}$ \\
\hline Creatinine level (median, umol/l) & $87 / 75$ & $93 / 86$ & $121 / 74$ \\
\hline Haemoglobin level (median, g/l) & $115 / 109$ & $111 / 116$ & $117 / 107$ \\
\hline $\begin{array}{l}\text { ISS at diagnosis } \\
\text { Stage } 1 \\
\text { Stage } 2 \\
\text { Stage } 3\end{array}$ & $\begin{array}{l}23.1 \% / 18.5 \% \\
38.9 \% / 23.6 \% \\
38.0 \% / 39.5 \% \\
\end{array}$ & $\begin{array}{l}30.2 \% / 23.7 \% \\
40.7 \% / 20.1 \% \\
29.1 \% / 39.6 \% \\
\end{array}$ & $\begin{array}{c}46.7 \% / 12.0 \% \\
6.7 \% / 29.0 \% \\
46.7 \% / 44.0 \% \\
\end{array}$ \\
\hline $\begin{array}{l}\text { Prior Velcade exposure } \\
\text { Refractory to }{ }^{1:} \\
\text { IMiD } \\
\text { Velcade } \\
\text { SCT status (yes) }{ }^{2}\end{array}$ & $\begin{array}{l}61.9 \% / 46.5 \% \\
17.6 \% / 12.1 \% \\
38.6 \% / 3.8 \% \\
22.1 \% / 49.7 \% \\
\end{array}$ & $\begin{array}{l}94.8 \% / 75.4 \% \\
34.3 \% / 24.5 \% \\
39.4 \% / 18.0 \% \\
38.5 \% / 70.5 \% \\
\end{array}$ & $\begin{array}{l}100.0 \% \text { / } 82.0 \% \\
58.3 \% \text { / } 35.0 \% \\
46.7 \% \text { / } 27.0 \% \\
26.7 \% \text { / 53.0\% }\end{array}$ \\
\hline
\end{tabular}

Note: Percentages may not add up to $100 \%$ due to rounding or missing data. 
Supplementary Table 2.2. Multiple Cox regression analysis of PFS, detailed output.

\begin{tabular}{|c|c|c|c|c|c|c|}
\hline \multirow{3}{*}{$\begin{array}{l}\text { Covariate } \\
\text { Treatment }\end{array}$} & \multirow{3}{*}{$\begin{array}{c}\text { Subgroup } \\
\text { KRd }\end{array}$} & \multirow{3}{*}{$\begin{array}{c}\begin{array}{c}\text { Reference } \\
\text { Group }\end{array} \\
\mathrm{Rd}\end{array}$} & \multicolumn{3}{|c|}{ Hazard Ratio } & \multirow{3}{*}{$\begin{array}{c}\text { p-value } \\
\text { (2-sided) } \\
<0.0001\end{array}$} \\
\hline & & & \multirow{2}{*}{\begin{tabular}{|c|} 
Point Estimate \\
0.641
\end{tabular}} & \multicolumn{2}{|c|}{$95 \%$ CI } & \\
\hline & & & & 0.526 & 0.781 & \\
\hline Baseline Hemoglobin Level Category & $\geq 105 \mathrm{~g} / \mathrm{L}$ & $<105 \mathrm{~g} / \mathrm{L}$ & 0.658 & 0.531 & 0.814 & 0.0001 \\
\hline Baseline Platelet Level Category & $\geq 150 \times 10^{9} / \mathrm{L}$ & $<150 \times 10^{9} / \mathrm{L}$ & 0.665 & 0.535 & 0.825 & 0.0002 \\
\hline $\begin{array}{l}\text { Baseline Corrected Calcium Level } \\
\text { Category }\end{array}$ & $\begin{array}{l}<=11.5 \\
\mathrm{mg} / \mathrm{dL}\end{array}$ & $>11.5 \mathrm{mg} / \mathrm{dL}$ & 0.610 & 0.347 & 1.073 & 0.0863 \\
\hline Disease Stage at Initial Diagnosis & Missing & II & 0.771 & 0.553 & 1.073 & 0.1232 \\
\hline Disease Stage at Initial Diagnosis & I & II & 0.730 & 0.533 & 1.001 & 0.0510 \\
\hline Disease Stage at Initial Diagnosis & III & II & 0.986 & 0.777 & 1.251 & 0.9091 \\
\hline$\beta 2$ Microglobulin Level Category & $<2.5 \mathrm{mg} / \mathrm{L}$ & $\geq 2.5 \mathrm{mg} / \mathrm{L}$ & 0.790 & 0.603 & 1.034 & 0.0863 \\
\hline Risk Group as Determined by FISH & Standard & High & 0.642 & 0.476 & 0.866 & 0.0037 \\
\hline Risk Group as Determined by FISH & Unknown & High & 0.667 & 0.499 & 0.893 & 0.0065 \\
\hline $\begin{array}{l}\text { Prior Bortezomib Exposure (used for } \\
\text { randomization stratification) }\end{array}$ & No & Yes & 0.745 & 0.603 & 0.919 & 0.0061 \\
\hline Refractory to prior IMiD Regimen & No & Yes & 0.529 & 0.425 & 0.657 & $<0.0001$ \\
\hline
\end{tabular}

Abbreviations: $\mathrm{CI}=$ confidence interval; FISH = fluorescent in situ hybridization; IMiD = immunomodulatory drug; Source: Amgen, data on file. 
Supplementary Table 2.3. Multiple Cox regression analysis of OS, detailed output.

\begin{tabular}{|c|c|c|c|c|c|c|}
\hline \multirow{3}{*}{\begin{tabular}{|l} 
Covariate \\
Treatment
\end{tabular}} & \multirow{3}{*}{$\begin{array}{c}\text { Subgroup } \\
\text { KRd }\end{array}$} & \multirow{3}{*}{$\begin{array}{c}\begin{array}{c}\text { Reference } \\
\text { Group }\end{array} \\
\mathrm{Rd}\end{array}$} & \multicolumn{3}{|c|}{ Hazard Ratio } & \multirow{3}{*}{$\begin{array}{c}\text { p-value } \\
\text { (2-sided) } \\
0.001\end{array}$} \\
\hline & & & \multirow{2}{*}{\begin{tabular}{|c|} 
Point Estimate \\
0.731
\end{tabular}} & \multicolumn{2}{|c|}{$95 \% \mathrm{CI}$} & \\
\hline & & & & 0.612 & 0.872 & \\
\hline Sex & Male & Female & 1.185 & 0.989 & 1.419 & 0.066 \\
\hline ECOG & 1 & 0 & 0.990 & 0.820 & 1.196 & 0.917 \\
\hline ECOG & 2 & 0 & 2.035 & 1.525 & 2.716 & 0.000 \\
\hline Baseline Hemoglobin Level Category & $\geq 105 \mathrm{~g} / \mathrm{L}$ & $<105 \mathrm{~g} / \mathrm{L}$ & 0.643 & 0.531 & 0.780 & 0.000 \\
\hline Baseline Platelet Level Category & $\geq 150 \times 109 / \mathrm{L}$ & $\begin{array}{r}<150 \\
\times 109 / \mathrm{L}\end{array}$ & 0.604 & 0.498 & 0.733 & 0.000 \\
\hline Baseline Creatinine Clearance & \multicolumn{2}{|c|}{ Continuous variable } & & 0.994 & 0.991 & 0.998 \\
\hline Disease Stage at Initial Diagnosis & Missing & II & 1.232 & 0.931 & 1.632 & 0.145 \\
\hline Disease Stage at Initial Diagnosis & I & II & 1.220 & 0.944 & 1.577 & 0.128 \\
\hline Disease Stage at Initial Diagnosis & III & II & 1.155 & 0.839 & 1.591 & 0.377 \\
\hline$\beta 2$ Microglobulin Level Category & $<2.5 \mathrm{mg} / \mathrm{L}$ & $\geq 2.5 \mathrm{mg} / \mathrm{L}$ & 1.490 & 1.146 & 1.937 & 0.003 \\
\hline Refractory to prior IMiD Regimen & Yes & No & 1.518 & 1.238 & 1.861 & 0.000 \\
\hline
\end{tabular}

Abbreviations: $\mathrm{CI}=$ confidence interval; ECOG = Eastern Cooperative Oncology Group; IMiD = immunomodulatory drug; Source: Amgen, data on file. 
Supplementary Table 2.4. Percentage of patients receiving each subsequent treatment after progression, per treatment line, in the RMG.

\begin{tabular}{|l|c|c|c|}
\hline & $\begin{array}{c}\text { After 2L } \\
(\mathbf{n = 6 2})\end{array}$ & After 3L (n=53) & After 4L (n=3) \\
\hline Bortezomib & $37.1 \%$ & $35.8 \%$ & $0.0 \%$ \\
\hline Lenalidomide & $11.3 \%$ & $9.4 \%$ & $66.7 \%$ \\
\hline Thalidomide plus & $17.7 \%$ & $26.4 \%$ & $0.0 \%$ \\
\hline $\begin{array}{l}\text { Cyclophosphamide } \\
\text { dexamethasone }\end{array}$ & $19.4 \%$ & $9.4 \%$ & $0.0 \%$ \\
\hline $\begin{array}{l}\text { Pomalidomide } \\
\text { dexamethasone }\end{array}$ & $0.0 \%$ & $7.5 \%$ & $0.0 \%$ \\
\hline Bortezomib plus thalidomide & $0.0 \%$ & $0.0 \%$ & $0.0 \%$ \\
\hline Other ${ }^{\mathrm{a}}$ & $14.5 \%$ & $11.5 \%$ & $33.3 \%$ \\
\hline
\end{tabular}

2L, second line; 3L, third line; 4L, fourth line; n, number of patients; RMG, Registry of Monoclonal Gammopathies. aThe cost of "other" treatments was assumed to be the minimum cost among all the subsequent treatments.

\section{Supplementary Table 2.5. Duration of subsequent treatments after progression, per} treatment line, in the RMG.

\begin{tabular}{|l|c|c|c|}
\hline & $\begin{array}{c}\text { After 2L } \\
(\mathbf{n}=\mathbf{6 2})\end{array}$ & $\begin{array}{c}\text { After 3L } \\
(\mathbf{n}=\mathbf{5 3})\end{array}$ & After 4L (n=3) \\
\hline Duration (weeks) & 21.9 & 14.1 & 31.7 \\
\hline
\end{tabular}

2L, second line; 3L, third line; 4L, fourth line; n, number of patients; RMG, Registry of Monoclonal Gammopathies. 
Supplementary Table 2.6. Monitoring costs.

\begin{tabular}{|l|c|c|c|c|}
\hline Item & $\begin{array}{c}\text { Proportion } \\
\text { of patients } \\
\text { tested }\end{array}$ & $\begin{array}{c}\text { Test } \\
\text { frequency } \\
\text { (per cycle) }\end{array}$ & $\begin{array}{c}\text { Unit cost } \\
(\boldsymbol{\epsilon})\end{array}$ & $\begin{array}{c}\text { Cost per } \\
\text { 28-day } \\
\text { cycle (€) }\end{array}$ \\
\hline Skeletal survey by x-ray & $53.85 \%$ & 0.05 & 8.60 & 0.21 \\
\hline Serum protein assessment & $100 \%$ & 1.11 & 2.43 & 2.71 \\
\hline Lab results - haematology & $100 \%$ & 2.02 & 2.51 & 5.05 \\
\hline Lab results - blood chemistry & $100 \%$ & 1.75 & 2.31 & 4.05 \\
\hline $\begin{array}{l}\text { Lab results - thyroid function } \\
\text { test }\end{array}$ & $100 \%$ & 1.75 & 2.31 & 4.05 \\
\hline Specialist visit (haematologist) & $100 \%$ & 2.26 & 6.83 & 15.39 \\
\hline
\end{tabular}


Supplementary Table 2.7. AIC values associated with PFS, OS and TTD curves of patients receiving $R d$ in the $R M G$, per treatment line.

\begin{tabular}{|l|c|c|c|c|c|c|c|c|c|}
\hline & \multicolumn{3}{|c|}{ PFS } & \multicolumn{3}{c|}{ OS } & \multicolumn{3}{c|}{ TTD } \\
\hline & 2L & 3L & 4L & 2L & 3L & 4L & 2L & 3L & 4L \\
\hline Exponential & 299.47 & 267.59 & 43.64 & 220.21 & 219.81 & 42.65 & 276.93 & 244.03 & 38.56 \\
\hline Weibull & 297.23 & 267.15 & 44.61 & 221.77 & 219.75 & 44.36 & 231.29 & 221.72 & 34.45 \\
\hline Gompertz & 301.46 & 269.58 & 44.07 & 221.91 & 221.51 & 43.55 & 235.42 & 230.83 & 34.25 \\
\hline Log-logistic & 291.41 & 262.77 & 46.71 & 222.64 & 218.69 & 43.52 & 248.95 & 226.74 & 37.12 \\
\hline Log-normal & 297.21 & 263.64 & 46.83 & 222.62 & 219.34 & 43.84 & 256.74 & 237.29 & 37.93 \\
\hline $\begin{array}{l}\text { Generalised } \\
\text { gamma }\end{array}$ & 295.17 & 264.25 & $\mathrm{NA}^{\mathrm{a}}$ & 223.58 & 220.26 & 45.77 & 232.12 & 223.22 & 35.96 \\
\hline
\end{tabular}

2L, second line; 3L, third line; 4L, fourth line; NA, not available; OS, overall survival; PFS, progression-free survival; Rd, lenalidomide/dexamethasone; RMG, Registry of Monoclonal Gammopathies; TTD, time to discontinuation. ${ }^{\mathrm{a} C}$ Could not be computed. 
Publication details: Eur J Health Econ. 2019 Oct 31. doi: 10.1007/s10198-019-01122-6.

Impact factor: $2.17(2018)$

Authors: M Campioni ${ }^{\text {**, I Agirrezabal }}{ }^{\mathrm{a}}$, R Hajek ${ }^{\mathrm{b}}$, J Minarik ${ }^{\mathrm{c}}$, L Pour ${ }^{\mathrm{d}}$, I Spicka ${ }^{\mathrm{e}}$, S Gonzalez-McQuire ${ }^{\mathrm{f}}$, P Jandova ${ }^{\mathrm{g}}$, V Maisnar ${ }^{\mathrm{e}}$

\section{Affiliations:}

${ }^{a}$ Economic Modeling Center of Excellence, Global Health Economics, Amgen (Europe) $\mathrm{GmbH}$, Zug, Switzerland.

b Department of Haematooncology, University Hospital Ostrava and Faculty of Medicine, University of Ostrava, 17. listopadu 1790, 70852 Ostrava, Czech Republic.

${ }^{\mathrm{c}}$ Department of Hemato-Oncology, University Hospital Olomouc and Faculty of Medicine and Dentistry, Palacky University Olomouc, I. P. Pavlova 185/6, 77900 Olomouc, Czech Republic.

${ }^{\mathrm{d}}$ Department of Internal Medicine, Hematology and Oncology, University Hospital Brno and Faculty of Medicine Masaryk University, Jihlavská 340/20, 62500 Brno - Bohunice-Brno-Starý Lískovec, Czech Republic.

${ }^{\mathrm{e}}$ Department of Internal Medicine, Charles University in Prague, First Faculty of Medicine and General Teaching Hospital, Katerinska 32, 12108 Prague, Czech Republic.

${ }^{\mathrm{f}}$ Global Health Economics, Amgen (Europe) GmbH, Zug, Switzerland.

${ }^{g}$ Amgen s.r.o., Prague, Czech Republic.

Correspondence to: Marco Campioni; Email: campioni@amgen.com; Phone: +41413692788

Declaration of interest: M Campioni is an employee of Amgen and owns stock in Amgen. I Agirrezabal is an employee of Amgen. R Hajek has received research funding from Amgen, Takeda, Novartis and Janssen; consultancy fees from Amgen, Celgene, Takeda, Bristol-Myers Squibb and Janssen; and honoraria from Amgen, Celgene, Takeda, Bristol-Myers Squibb and Janssen. J Minarik and L Pour declare that they have no conflict of interest. I Spicka has received research funding from Celgene; and honoraria from Amgen, Bristol-Myers Squibb, Celgene, Janssen, Novartis and Takeda. S Gonzalez-McQuire is an employee of Amgen and owns stock in Amgen. P Jandova is an employee of Amgen and owns stock in Amgen. V Maisnar has received research funding from The Binding Site; worked as consultant for Amgen, Bristol-Myers Squibb, Celgene and Takeda; and received honoraria from Janssen.

Funding: This work was funded by Amgen (Europe) GmbH.

Note: Table and figure numbers are not shown as published. These have been updated to show the chapter number in this thesis. 
Chapter 3

Inequalities in prescription rates of anti-osteoporosis drugs in primary care in England: a practice-level prescribing data analysis in 2013-2018

Bone. 2020 Jan;130:115125. doi: 10.1016/j.bone.2019.115125. Epub 2019 Nov 2 


\begin{abstract}
Objective: To investigate potential variations in prescription rates of anti-osteoporosis drugs at the general practitioner (GP) practice level in England, analysing associations of prescription rates with key demographic and socio-economic variables, and its evolution over time.
\end{abstract}

Methods: A retrospective database analysis was conducted using prescription data from all GP practices in England between April 2013 and September 2018. Potential associations between prescription rates and other variables (sex, age, ethnicity, ruralurban classification and income deprivation) were analysed using mixed-effects Poisson regressions and concentration indices.

Results: Alendronic acid was the most frequently prescribed anti-osteoporosis drug. Exploratory and regression analyses showed the association between GP prescriptions and the characteristics of the population they serve. Income deprivation had a statistically significant and negative effect on prescription levels of alendronic acid, denosumab, ibandronic acid and risedronate sodium. Since 2013, denosumab prescriptions exhibited a steep surge in the least income-deprived areas, compared with a modest rise in the most income-deprived areas. Concentration indices indicated a disproportionate concentration of denosumab and, to a lesser extent, ibandronic acid prescriptions among the least income-deprived. The analyses demonstrated that different prescribing behaviours may exist across GPs according to the Clinical Commissioning Group (CCG) to which they belong.

Conclusions: Variation in the prescription of anti-osteoporosis drugs exists across GPs and CCGs in England, this being more prominent for certain drugs (e.g. denosumab) compared with others (e.g. alendronic acid). Inequalities exist in English primary healthcare and we advocate our findings could support the efforts of decision-makers towards a more equitable system.

\title{
KEYWORDS
}

Osteoporosis; Prescriptions; General practitioner; Health determinants; Deprivation; England.

\section{KEY ABBREVIATIONS}

AIC, Akaike information criterion; AUC, area under the curve; BIC, Bayesian information criterion; BNF, British National Formulary; CCG, Clinical Commissioning Group; CI, concentration index; GP, general practitioner; IMD, Index of Multiple Deprivation; LSOA, Lower-layer Super Output Area; LRT, likelihood ratio test; ONS, Office for National Statistics; RUC, rural-urban classification; TA, technology appraisal. 


\section{INTRODUCTION}

Spatial and temporal variation in drug prescription rates is a common phenomenon within and across healthcare settings and, although a certain level can be justified considering the biologic and demographic characteristics of patient populations, in many cases the observed variations may be larger than what could be considered fair by international standards of human rights, reflecting underlying inequalities within healthcare systems $[1,2]$. Significant differences in drug prescription rates have been found in a number of disease areas across countries, regions, and even lower organisational levels such as districts or municipalities, which highlights the importance of addressing this issue at all layers of healthcare decision-making, including international organisations in the healthcare sector [3-15]. Importantly, these variations in prescription rates may also translate into inconsistent, and often superfluous, drug expenditure, which has become a critical issue in healthcare systems where healthcare commissioners are struggling to cope with increasing demands under heavily constrained budgets.

A fundamental part for understanding and addressing variations and inequalities is to identify their determinants, and common findings across many studies in different disease areas indicate that key socio-demographic variables such as sex, age, economic status, education level, ethnicity and level of urbanisation of the area where individuals live have a significant impact on varying prescription rates $[4,6,8,10,15,12]$. For instance, several studies have demonstrated uneven antibiotic prescription rates in Italian children, with greater use of antibiotics in the more deprived southern regions (in terms of income and Human Development Index [HDI]) in line with the well-described north-south socio-economic polarisation $[11,16]$. But examples like this one abound. A study conducted by the Organisation for Economic Co-operation and Development (OECD) stressed that it is essential to tackle inequality by focusing at the bottom of the income distribution, putting in place policies that promote and increase access to highquality education and healthcare [17]. This, the OECD stated, would not only make societies less unfair, but also richer [17]. Therefore, minimising inequalities in the access to healthcare across socio-economic groups and distributing the resources available based on the needs of the patients being served should be a key goal for healthcare policy-makers $[18,19]$. This, with a particular commitment to ensuring social justice through the development of primary care, was put at the centre of health policy discussions with the Astana Declaration [20].

Variation in prescription rates may also exist in the case of anti-osteoporosis drugs. Recent reports have estimated that three million people in the UK have osteoporosis, 
and over 500,000 people present with fragility fractures (i.e. fractures that result from mechanical forces that would not normally result in fracture), which represents a significant financial burden to the National Health Service (NHS) of approximately $£ 4.4$ billion a year, equivalent to $£ 8,800$ per person with a fragility fracture $[21,22]$. The National Institute for Health and Care Excellence (NICE) have highlighted the importance of identifying the individuals at high risk of fragility fractures and offering treatments to improve bone density and reduce fracture risk, which is perhaps more relevant than ever given the estimated increase in the epidemiological burden of osteoporosis in the UK and the ever-increasing ageing population [22, 23]. Also, NICE have conducted several technology appraisals (TAs) since 2008, assessing the antiosteoporosis drugs available on the market and issuing guidance about how and when to use them (if recommended) [24-28]. These anti-osteoporosis drugs include bisphosphonates (such as alendronic acid, ibandronic acid and risedronate sodium), a selective oestrogen receptor modulator (raloxifene) and a monoclonal antibody that inhibits osteoclasts' function (denosumab). Despite NICE guidance, however, a clinical audit conducted in 2016 showed a substantial gap between what is recommended and what is done in reality in relation to secondary prevention of fragility fractures in England and Wales: only $34 \%$ of people aged 50 or over who had sustained a fragility fracture were recommended bone protection therapy, of whom only $31 \%$ were treated within four months of their fracture [22]. From a healthcare decision-maker's perspective, and given this proof of suboptimal treatment patterns, it is crucial to ensure an efficient and fair distribution of resources, and it is therefore important to understand how GPs prescribe anti-osteoporosis drugs and how these are distributed across the population. This may be even more important considering that substantial differences exist in their prices due to the availability of generic treatments for bisphosphonates and raloxifene, compared with the branded denosumab (Online Resource, Appendix 1).

In line with this, we set out to produce some evidence to steer policy discussions towards a more equitable primary care in publicly funded healthcare systems. Firstly, we evaluated the levels of prescription rates of anti-osteoporosis drugs at the GP practice level in England, as well as their temporal trends. Secondly, we investigated whether the demographic and socio-economic characteristics of the patients being served (i.e. sex, age, ethnic group composition, rural-urban classification and income deprivation) were significant predictors of anti-osteoporosis drug prescription rates. Finally, we analysed potential inequalities in anti-osteoporosis drug prescription rates, evaluating whether inequality levels differ across drug types, and examined the evolution of inequality over time to assess whether there is, or there is not, a potential trend towards a more equitable primary care system in England. 


\section{METHODS}

\section{Data sources}

In recent years, the UK Government have made public a large amount of data as part of its commitment for greater transparency, including data on treatments prescribed by GP practices in England, characteristics of patients registered with GP practices, ethnic group composition, rural-urban classification (RUC) of specific geographic areas and deprivation status [29]. Comprehensive datasets available online are accessible via the NHS Digital, GOV.UK and Office for National Statistics (ONS) portals [30-35].

\section{Variables}

\section{GP practice-level prescription data}

On December $17^{\text {th }}, 2018$, we extracted the data on each individual treatment (identified by a unique British National Formulary [BNF] code) prescribed by each GP practice in England and dispensed in the community in the UK, with the corresponding number of prescribed items that were dispensed. Location data such as postcode and information on the Clinical Commissioning Group (CCG) to which each GP practice belongs were also available. Prescribing information datasets were available monthly, recording data starting from August 2010 until September 2018 (at the time of data collection), but we did not include data before April 2013 in the current analysis due to the lack of other relevant datasets in that period (see Section "Patient demographics"). Therefore, for the current analysis we used the datasets containing monthly prescription data from April 2013 until September 2018.

We filtered these datasets to generate datasets capturing prescriptions for alendronic acid (with and without colecalciferol), denosumab, ibandronic acid, raloxifene and risedronate sodium. We considered these products in our analyses because NICE had assessed and recommended their use in routine practice at some point and because these drugs are most frequently prescribed in primary care (Table 3.1). The drugs that could have been potentially included but were excluded from the analysis, as well as the reason for their exclusion (e.g. because NICE did not include the drug in the latest technology appraisals or because the number of prescriptions by GPs in England are close to zero), are reported in Online Resource, Appendix 2. All prescribing data have also been made available to the public through a user-friendly interface (OpenPrescribing.net) developed by the Evidence-based Medicine DataLab at the University of Oxford. This allowed us to validate the data used in our analyses by comparing the number of prescriptions included in our final datasets with the number of prescriptions reported at OpenPrescribing.net [36]. When prescription data were not reported for a given product by a GP practice, we considered the number of prescriptions for that product to be zero. 
Table 3.1. Products included in the analysis and the reason for their inclusion.

\begin{tabular}{|c|c|c|}
\hline Product & $\begin{array}{l}\text { Mode of } \\
\text { administration }\end{array}$ & Reason for inclusion \\
\hline $\begin{array}{l}\text { Alendronic } \\
\text { acid }\end{array}$ & Oral & $\begin{array}{l}\text { Alendronic acid has been consistently recommended by NICE as a key treatment for osteoporosis }[24,25 \text {, } \\
28] \text {. By being a product administered orally, alendronic acid is expected to be prescribed primarily by GPs. }\end{array}$ \\
\hline $\begin{array}{l}\text { Alendronic } \\
\text { acid and } \\
\text { colecalciferol }\end{array}$ & Oral & $\begin{array}{l}\text { NICE have considered alendronic acid with and without colecalciferol (vitamin D3) as one single technology } \\
\text { [27], and therefore the conclusions drawn by NICE for alendronic acid are also applicable when it is } \\
\text { combined with colecalciferol. By being a product administered orally, alendronic acid and colecalciferol is } \\
\text { expected to be prescribed primarily by GPs. }\end{array}$ \\
\hline $\begin{array}{l}\text { Denosumab } \\
\text { (excluding } \\
\text { XGEVA®) }\end{array}$ & Subcutaneous & $\begin{array}{l}\text { NICE (TA204) recommended denosumab for a specific group of osteoporosis patients for whom oral } \\
\text { bisphosphonates are unsuitable [26]. Although denosumab treatment may be started in secondary care, all } \\
\text { subsequent administrations are expected to be delivered in primary care [37]. }\end{array}$ \\
\hline $\begin{array}{l}\text { Ibandronic } \\
\text { acid }\end{array}$ & $\begin{array}{l}\text { Oral and } \\
\text { intravenous } \\
\text { (IV) }\end{array}$ & $\begin{array}{l}\text { Both the oral and IV forms of ibandronic acid were recommended by NICE TA464 [28]. Intravenous } \\
\text { ibandronic acid is expected to be delivered mainly in secondary care, whereas its oral formulation primarily } \\
\text { by GPs. The GP prescribing datasets capture both oral and IV prescriptions by GPs in England and, although } \\
\text { most prescriptions correspond to the oral formulation [31]. }\end{array}$ \\
\hline Raloxifene & Oral & $\begin{array}{l}\text { NICE recommended raloxifene (TA161) for the secondary prevention of osteoporotic fractures in a specific } \\
\text { subgroup of postmenopausal women [24]. By being a product administered orally, raloxifene is expected to } \\
\text { be prescribed primarily by GPs. }\end{array}$ \\
\hline
\end{tabular}

GP, general practitioner; IV, intravenous; NICE, National Institute for Health and Care Excellence; TA, technology appraisal. 


\section{Patient demographics}

We retrieved the details on the patient population registered at each GP practice (except for those practices with 100 or fewer patients which are unavailable for privacy reasons). These datasets reported the number of patients registered at each GP practice by sex and age band; from these, we calculated the proportion of females and the mean age of patients registered at each GP practice. Quarterly data are available from April 2013 to January 2017, and monthly data have been published thereafter. When data for a given month were not available (between April 2013 and January 2017), we conducted a linear interpolation between the two closest data points, assuming a linear change in potential differences in the sex (as a proportion of females) and age structure over time.

\section{Ethnic composition of the local area}

To incorporate ethnicity in our analyses, we obtained the 2011 ethnic group composition data from the ONS and calculated the percentage of white people for each Lower-layer Super Output Area (LSOA) in England, i.e. small areas with a similar population size and an average of 1,500 residents or 650 households. White people, as per the ONS classification, included English, Welsh, Scottish, (Northern) Irish, Gypsy or Irish Traveller, and Other White categories.

\section{Rural-urban classification of the local area}

We collected the 2011 RUC data of LSOAs from the ONS, which classifies each LSOA into one of four urban or six rural categories. For this analysis, we combined all rural sub-categories in a single "rural" category, while all urban sub-categories formed a single "urban" category. We considered these cross-sectional data on ethnicity and rural category for the entire analysis time frame due to the lack of more up-to-date data. Nevertheless, we did not expect any specific trends during the observation period.

\section{Deprivation of the local area}

The Index of Multiple Deprivation (IMD) is the official measure of deprivation in England and is generated combining information from seven domains with a particular weighting scheme (income: $22.5 \%$; employment: $22.5 \%$; education, skills and training: 13.5\%; health and disability: $13.5 \%$; crime: $9.3 \%$; barriers to housing and services: 9.3\%; and living environment: 9.3\%) [35]. The IMD and its seven domain indices were available for each LSOA. These indices rank each LSOA from 1 (the most deprived area) to 32,844 (the least deprived area) and are calculated from scores which, in the case of the income and employment domains, are meaningful and can be interpreted as the proportion of the population experiencing the corresponding type of deprivation. We considered income deprivation as the key variable for analysis in line with our research objectives and the evidence available in the literature. Our analyses incorporated income deprivation as a score and as a decile. The latest available IMD version at the time of 
manuscript submission was from 2015 [35].

\section{Variables summary}

Figure 3.1 outlines the data sources used and summarises the process for linking all these together to generate a single dataset capturing the variables used in our analyses. These variables are also summarised in Table 3.2. Our final dataset only considered prescribing data for which details on patients registered were available, as otherwise the lack of data on the size of the GP practice would not let us put the number of prescriptions into context.

Figure 3.1. Summary of data sources and variables included in the analyses.

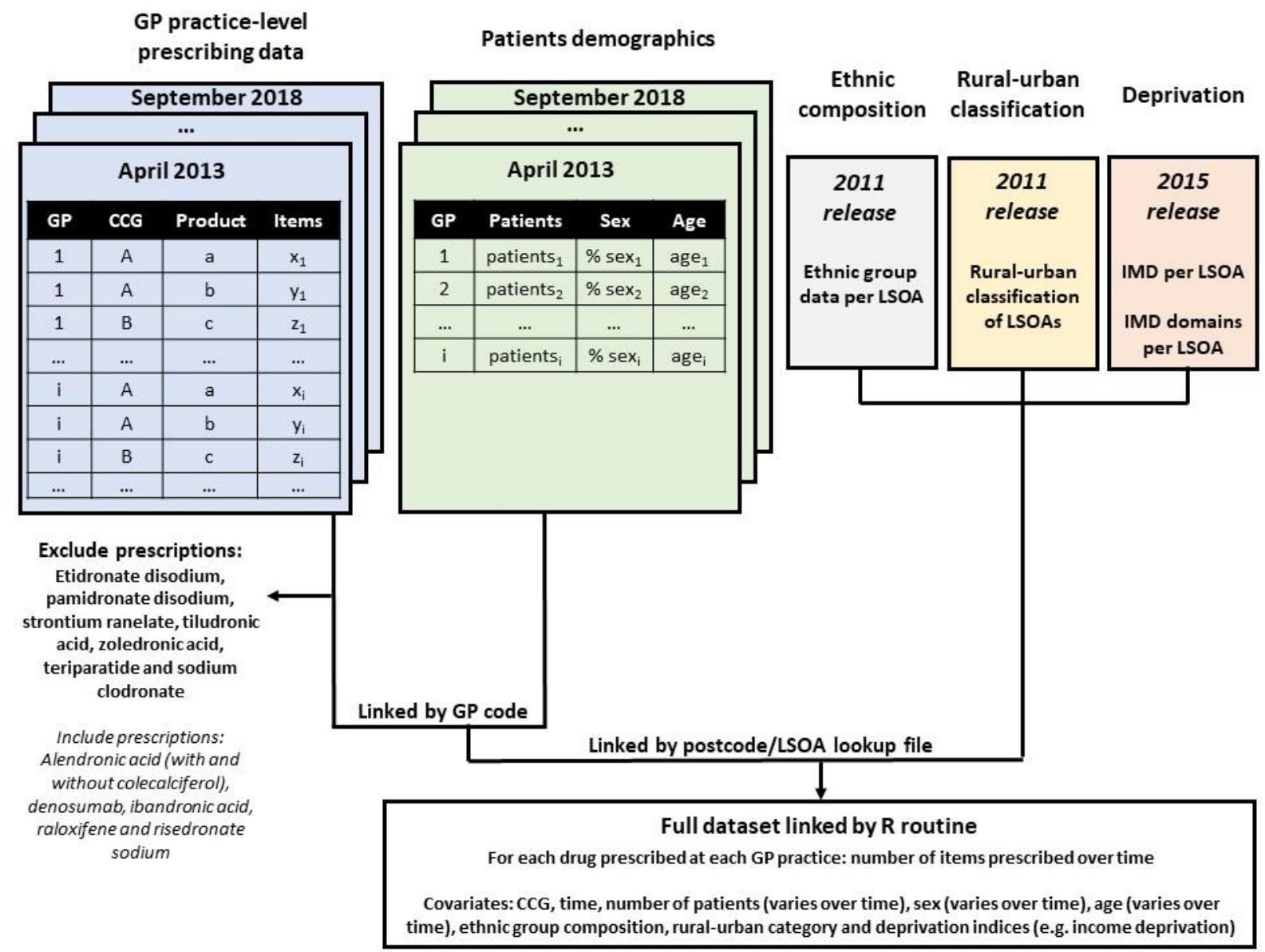


Table 3.2. Description of variables included in the analyses.

\begin{tabular}{|c|c|}
\hline Variable & Description \\
\hline GP & Identification code of a given GP practice $i$. \\
\hline $\mathrm{CCG}_{\mathrm{i}}$ & The CCG to which a given GP practice $i$ belongs. \\
\hline Product & BNF code associated with the product $p$ of interest. \\
\hline Time & Time $t$ (year and month) at which the products of interest were prescribed. \\
\hline Items $\mathrm{i}, \mathrm{t}, \mathrm{p}$ & $\begin{array}{l}\text { Number of items of product } p \text { prescribed by GP practice } i \text { at time } t \text { and } \\
\text { dispensed in the community in the UK. }\end{array}$ \\
\hline Patients $i_{i, t}$ & Number of patients registered with GP practice $i$ at time $t$. \\
\hline income.score $_{i}$ & $\begin{array}{l}\text { Proportion of the population in the LSOA where the GP practice } i \text { is located } \\
\text { experiencing deprivation relating to low income. This measure includes both } \\
\text { those people that are unemployed and those that are in work but have low } \\
\text { earnings. }\end{array}$ \\
\hline Income.decile $_{i}$ & Income deprivation decile of the LSOA where GP practice $i$ is located. \\
\hline $\operatorname{Sex}_{\mathrm{i}, \mathrm{t}}$ & $\begin{array}{l}\text { Proportion of females in the patient pool registered with GP practice } i \text { at } \\
\text { time } t \text {. }\end{array}$ \\
\hline $\operatorname{age}_{i, t}$ & $\begin{array}{l}\text { Average age, in years, of the patient pool registered with GP practice } i \text { at } \\
\text { time } t \text {. }\end{array}$ \\
\hline rural-urban ${ }_{i}$ & $\begin{array}{l}\text { Rural classification (either as 'rural' or 'urban') of the LSOA where GP } \\
\text { practice } i \text { is located. }\end{array}$ \\
\hline Ethnicityi & $\begin{array}{l}\text { Proportion of white people, as per the ONS classification, in the LSOA } \\
\text { where GP practice } i \text { is located. }\end{array}$ \\
\hline
\end{tabular}

BNF, British National Formulary; CCG, Clinical Commissioning Group; GP, general practitioner; LSOA, Lower-layer Super Output Area.

\section{Data analysis}

\section{Exploratory analyses}

We analysed the number of GP practices for which prescribing data were available, as well as the number of practices for which the characteristics of registered patients could be accessed. With these, we calculated the total number of prescriptions included in our final datasets and compared these numbers with those available online to ensure we did not miss a substantial amount of data [36]. We conducted several exploratory analyses to better understand the entire dataset and potential relationships between variables. To assess whether different prescribing behaviours may exist for different strata of the 
population according to income deprivation, we plotted the prescription rates over time for each product separately and by income deprivation decile. This analysis provided an understanding of the temporal trends of the prescription rates of each product.

\section{Regression analyses}

We implemented mixed-effects Poisson regression models (one for each product of interest) to assess whether, and how, prescription rates of anti-osteoporosis drugs are affected by demographic and socio-economic factors. Time, the number of patients registered, sex, age, ethnic group composition, rural-urban category and income deprivation score were included as fixed-effects variables (i.e. the full model); a random intercept was included for the GP practice. Also, we built regression models considering the income deprivation score as the sole fixed-effect variable (apart from time and the number of patients for normalisation purposes) to understand the effect of income deprivation in the absence of other explanatory variables (i.e. the reduced model). Clinical Commissioning Groups represent the organisational level in which funding decisions are made in England, potentially resulting in differential access to medicines [38]. Consequently prescription levels of a certain product may vary across CCGs, and for that reason we constructed models with and without random effects for CCGs [39]. We calculated the Akaike and Bayesian information criteria (AIC and BIC) associated with each of these models, and the models with and without random effects for CCGs were compared with a likelihood ratio test (LRT). We estimated marginal and conditional $\mathrm{R}^{2}$ values as described in the literature [40]. Model codes, as written in $\mathrm{R}$, are reported in Online Resource, Appendix 3.

\section{Analysis of inequalities}

We estimated concentration indices (CIs) to identify the potential presence of socioeconomic inequalities in prescription rates of anti-osteoporosis drugs in primary care in England. We plotted the cumulative number of prescriptions vs the cumulative number of patients ranked by income (i.e. concentration curves) and calculated the area under the curve (AUC) with the trapezoidal rule. The CIs were then calculated as: $\mathrm{CI}=2$ * (0.5-AUC) [41]. We compared the CIs and curves with the 45-degree line (or CI equal to zero), which would represent perfect equality assuming all GP practices are expected to have the same level of consumption regardless of the characteristics of the patient population they serve. Finally, we graphically analysed the evolution of CIs over time.

\section{Software}

Data collection, cleaning, manipulation and all analyses, as described below, were conducted using R version 3.5.1 and the key following packages: broom, caTools, curl, data.table, dplyr, ggplot2, lme4, readr, stringr [42]. 


\section{RESULTS}

\section{Exploratory analyses}

The exploratory analyses showed that the total number of GP practices in England has decreased since 2013, and even more so the number of GP practices for which both prescribing and patient data files are available (i.e. the ones we used in our analyses), going from 8,077 GP practices in April 2013 to 7,043 in September 2018 (Online Resource, Appendix 4). Nevertheless, there is no reason why we would think this could affect our analyses in any particular way. Alendronic acid was undeniably the antiosteoporosis drug most frequently prescribed by GPs in England, despite a steady decrease from approximately 600,000 items per month in 2013 (an average of 75.1 items per GP practice in April 2013) to 500,000 items per month in 2018 (68.3 items per GP practice in September 2018). Risedronate sodium was the next most commonly prescribed drug, followed by ibandronic acid and raloxifene (7.4, 1.8 and 0.6 items per GP practice, respectively, in September 2018). Denosumab, with a steady increase in prescriptions between 2013 and 2018, was at the time of analysis prescribed at a similar level than that of raloxifene (0.6 items per GP practice in September 2018). The combined alendronic acid and colecalciferol was the least prescribed product $(0.1$ items per GP practice in September 2018). The different prescription levels across drugs and distinct patterns over time justified the implementation of separate regression models for each product analysed (Online Resource, Appendix 5). By comparing our final dataset with the anti-osteoporosis drug prescription numbers available online at OpenPrescribing.net, we confirmed that our final dataset captured most of the prescriptions of interest (Online Resource, Appendix 5).

Our analyses indicated that different prescribing behaviours may exist across GPs in England according to income deprivation levels of the area where GPs are located, with the clearest examples of polarisation observed for denosumab, followed by ibandronic acid and raloxifene (Figure 3.2; please note the differences in scale of $\mathrm{Y}$ axes). Denosumab showed a considerably sharper increase in prescription rates in less deprived areas compared with more deprived areas, with more than a three-fold difference in prescription rates between the most and least deprived areas. Further exploratory analyses are reported in Online Resource, Appendix 6. 
Figure 3.2. Prescription rates, over time, for each product and by income deprivation decile (from 1, the most deprived, to 10, the least deprived).
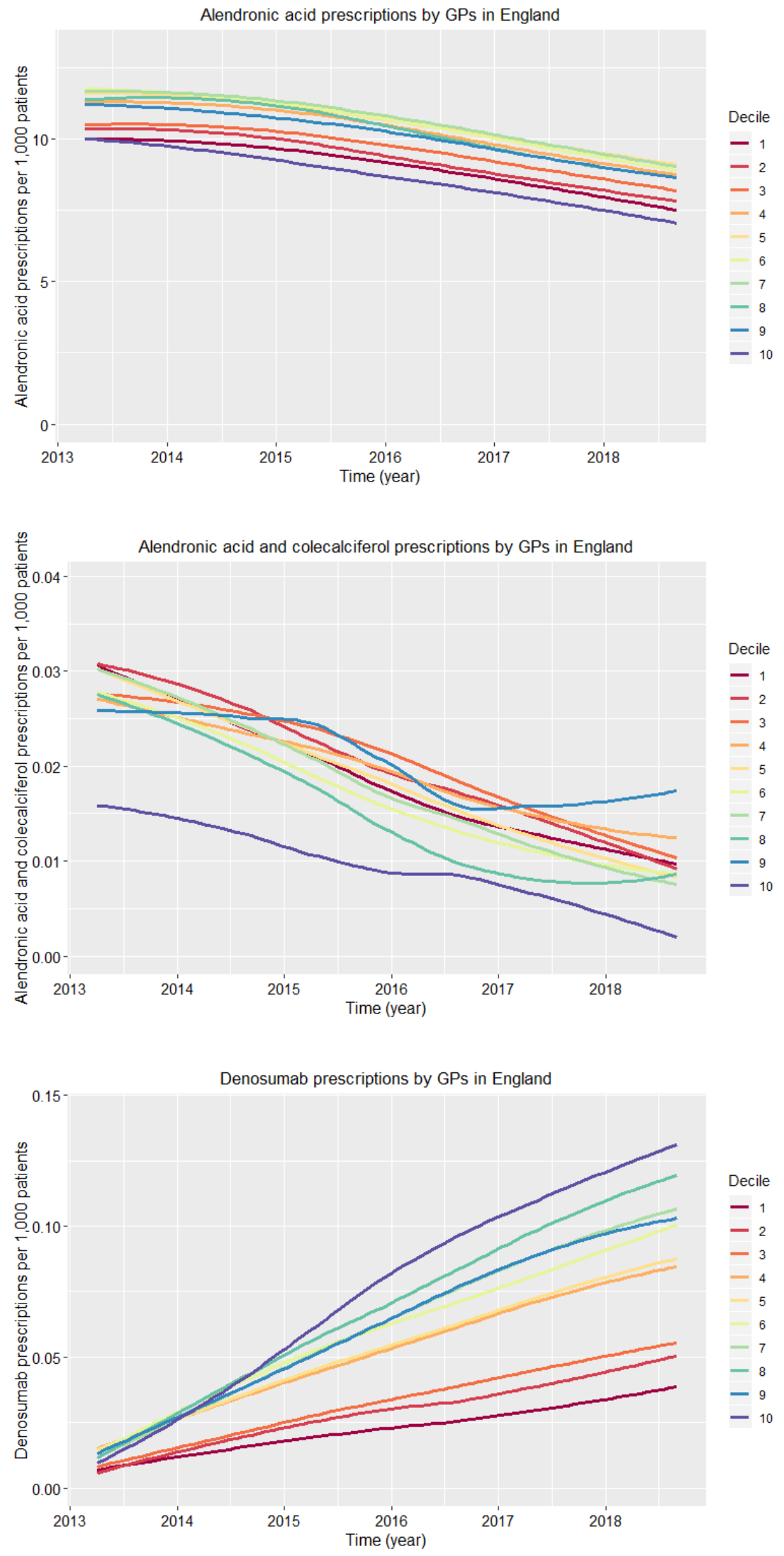
Figure 3.2. (continued) Prescription rates, over time, for each product and by income deprivation decile (from 1, the most deprived, to 10, the least deprived).
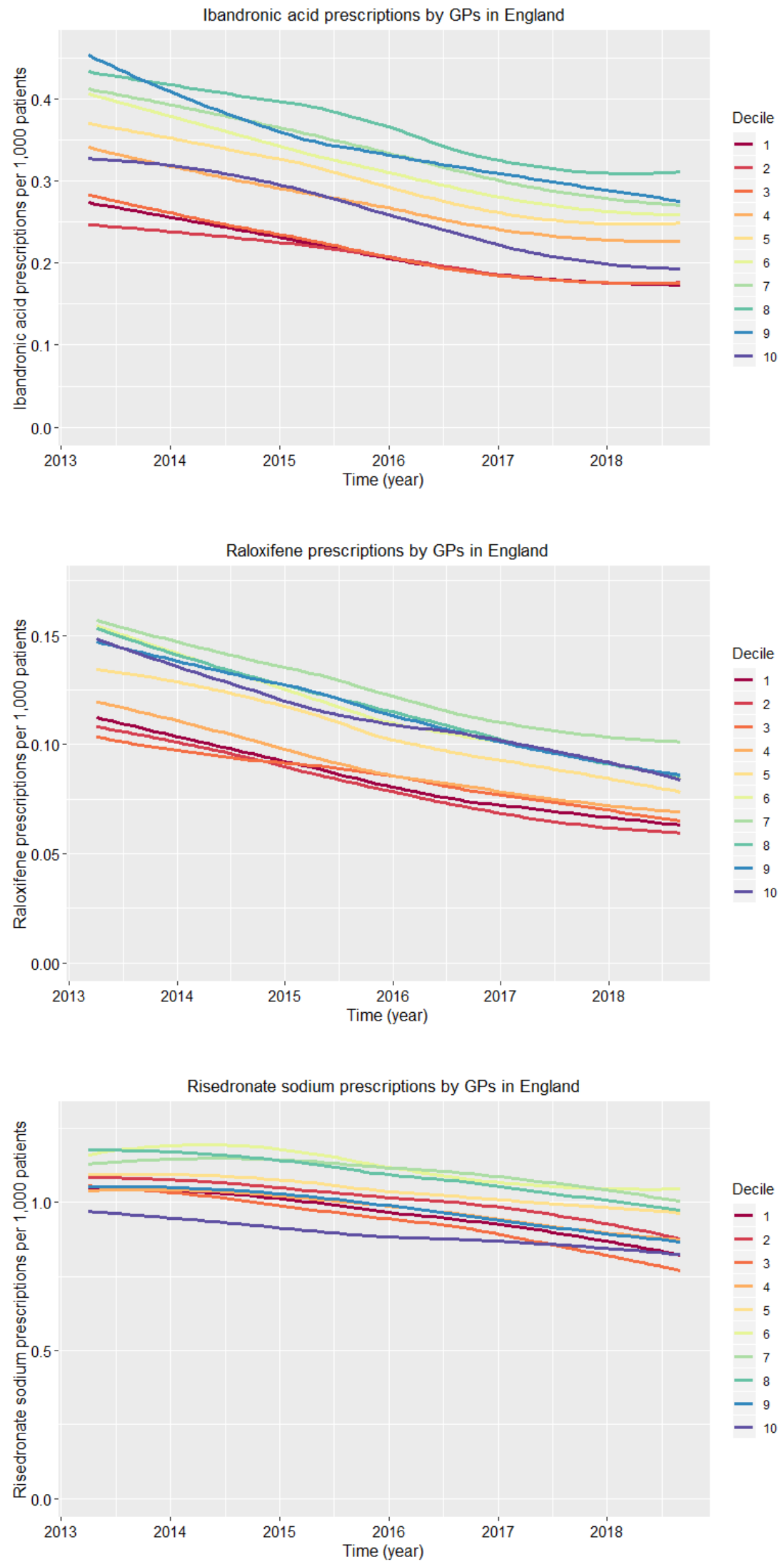


\section{Regression analyses}

Results from regression analyses are reported in Table 3.3. Our analyses showed that socioeconomic status, measured by income deprivation, was a statistically significant predictor (at a 5\% significance level) of prescription levels for most drugs. When adjusted for demographic and rural-urban characteristics, income deprivation had a negative effect on prescription levels of alendronic acid (with and without colecalciferol), denosumab, ibandronic acid and risedronate sodium, i.e. a larger proportion of the population experiencing deprivation relating to low income would mean, on average, lower prescription levels of these drugs. The results indicated the opposite, albeit not statistically significant at a 5\% significance level, effect for raloxifene. We observed a statistically significant and positive effect of sex (proportion of females registered with GPs) on prescription levels of all anti-osteoporosis drugs except for the combined alendronic acid and colecalciferol. Similarly, we identified statistically significant and positive effects of age (years) on prescription levels of all drugs, meaning that a higher mean age of patients registered with GPs was associated with higher anti-osteoporosis drug prescriptions rates. Our analyses suggested that the ethnic group composition had a statistically significant effect on prescription levels of all products: we observed that the larger the percentage of white people in the local area, the larger the amount of denosumab, ibandronic acid, raloxifene and risedronate sodium would be, and noted the opposite effect for alendronic acid with and without colecalciferol. We found that alendronic acid and colecalciferol, denosumab and ibandronic acid were more likely to be prescribed in urban areas, whereas alendronic acid, raloxifene and risedronate sodium were more likely to be prescribed in rural areas. We observed a large difference between the marginal and conditional $\mathrm{R}^{2}$ in all cases, which highlighted the importance of implementing a mixed-effects model structure. The results in Table 3.3 were largely aligned with the results illustrated in Figure 3.2.

In general, the reduced models yielded similar regression coefficients as those resulting from the full models, thereby validating the appropriateness of our analyses. The reduced models corroborated the influence of income deprivation on prescription levels of alendronic acid, denosumab, ibandronic acid and risedronate sodium, and implied that income deprivation may be affecting raloxifene prescription levels in a similar way. The differences in the marginal $\mathrm{R}^{2}$ between the full and reduced models provide a sense of the additional variability explained by the fixed factors excluded from the reduced models.

The regression analyses confirmed that it was appropriate to consider random effects for CCGs, suggesting that a substantial variation in anti-osteoporosis drug prescription levels may exist at the CCG level. All models yielded lower AIC and BIC values when 
random effects for CCGs were implemented and all twelve LRTs (one test comparing the models for each product [both the full and reduced models] with and without random effects for CCGs) were statistically significant $(p<0.001)$ in favour of the models with random effects. The models that included random effects for CCGs yielded higher conditional $\mathrm{R}^{2}$ values compared with those without random effects for CCGs, further emphasising the existing variability across CCGs. The regression model results without random effects for CCGs are reported in Online Resource, Appendix 7.

Finally, the regression analyses confirmed the time trends observed in the exploratory analyses, showing a negative trend (i.e. a reduction in prescription levels) for all drugs but denosumab. 
Table 3.3. Mixed-effects regression model results: estimates (and 95\% confidence intervals) of models with random effects for CCGs, with and without demographic and rural-urban characteristics.

\begin{tabular}{|c|c|c|c|c|c|c|c|c|c|c|c|c|}
\hline & \multicolumn{2}{|c|}{ Alendronic acid } & \multicolumn{2}{|c|}{$\begin{array}{l}\text { Alendronic acid } \\
\text { and colecalciferol }\end{array}$} & \multicolumn{2}{|c|}{ Denosumab } & \multicolumn{2}{|c|}{ Ibandronic acid } & \multicolumn{2}{|c|}{ Raloxifene } & \multicolumn{2}{|c|}{$\begin{array}{l}\text { Risedronate } \\
\text { sodium }\end{array}$} \\
\hline & $\begin{array}{l}\text { Full } \\
\text { model }\end{array}$ & $\begin{array}{l}\text { Reduced } \\
\text { model }\end{array}$ & $\begin{array}{l}\text { Full } \\
\text { model }\end{array}$ & $\begin{array}{c}\text { Reduced } \\
\text { model }\end{array}$ & $\begin{array}{l}\text { Full } \\
\text { model }\end{array}$ & $\begin{array}{c}\text { Reduced } \\
\text { model }\end{array}$ & $\begin{array}{l}\text { Full } \\
\text { model }\end{array}$ & $\begin{array}{l}\text { Reduced } \\
\text { model }\end{array}$ & $\begin{array}{l}\text { Full } \\
\text { model }\end{array}$ & $\begin{array}{l}\text { Reduced } \\
\text { model }\end{array}$ & $\begin{array}{c}\text { Full } \\
\text { model }\end{array}$ & $\begin{array}{l}\text { Reduced } \\
\text { model }\end{array}$ \\
\hline Intercept & $\begin{array}{c}106.669 \\
(106.231 \text { to } \\
107.107)^{* * *}\end{array}$ & $\begin{array}{l}87.570 \\
(87.251 \text { to } \\
87.889)^{* * *}\end{array}$ & $\begin{array}{c}429.432 \\
(428.553 \text { to } \\
430.311)^{* * *}\end{array}$ & $\begin{array}{c}390.752 \\
(389.218 \text { to } \\
392.285)^{* * *}\end{array}$ & $\begin{array}{c}-572.244 \\
(-575.279 \text { to } \\
-569.208)^{* * *}\end{array}$ & $\begin{array}{c}-603.583 \\
(-605.248 \text { to } \\
-601.918)^{* * *}\end{array}$ & $\begin{array}{c}182.845 \\
(181.813 \text { to } \\
183.876)^{* * *}\end{array}$ & $\begin{array}{c}159.433 \\
(158.694 \text { to } \\
160.172)^{* * *}\end{array}$ & $\begin{array}{c}205.446 \\
(203.549 \text { to } \\
207.342)^{* * *}\end{array}$ & $\begin{array}{c}188.403 \\
(186.763 \text { to } \\
190.042)^{* * *}\end{array}$ & $\begin{array}{c}66.461 \\
(65.964 \text { to } \\
66.959)^{* * *}\end{array}$ & $\begin{array}{c}52.699 \\
(52.119 \text { to } \\
53.279)^{* * *}\end{array}$ \\
\hline $\begin{array}{l}\text { Patients } \\
(1,000 \mathrm{~s})\end{array}$ & $\begin{array}{c}0.049 \\
(0.049 \text { to } \\
0.049)^{* * *}\end{array}$ & $\begin{array}{c}0.047 \\
(0.046 \text { to } \\
0.047)^{* * *}\end{array}$ & $\begin{array}{l}0.071 \\
(0.065 \text { to } \\
0.078)^{* * *}\end{array}$ & $\begin{array}{c}0.067 \\
(0.061 \text { to } \\
0.073)^{* * *}\end{array}$ & $\begin{array}{c}0.068 \\
(0.065 \text { to } \\
0.071)^{* * *}\end{array}$ & $\begin{array}{c}0.062 \\
(0.059 \text { to } \\
0.065)^{* * *}\end{array}$ & $\begin{array}{c}0.062 \\
(0.060 \text { to } \\
0.063)^{* * *}\end{array}$ & $\begin{array}{c}0.059 \\
(0.057 \text { to } \\
0.060)^{* * *}\end{array}$ & $\begin{array}{c}0.053 \\
(0.051 \text { to } \\
0.055)^{* * *}\end{array}$ & $\begin{array}{c}0.051 \\
(0.048 \text { to } \\
0.053)^{* * *}\end{array}$ & $\begin{array}{c}0.051 \\
(0.051 \text { to } \\
0.052)^{* * *}\end{array}$ & $\begin{array}{c}0.049 \\
(0.048 \text { to } \\
0.050)^{* * *}\end{array}$ \\
\hline $\begin{array}{l}\text { Income } \\
\text { score ( } \% \\
\text { deprived) }\end{array}$ & $\begin{array}{c}-0.001 \\
(-0.002 \text { to } \\
-0.001)^{* * *}\end{array}$ & $\begin{array}{c}-0.002 \\
(-0.002 \text { to } \\
-0.002)^{* * *}\end{array}$ & $\begin{array}{c}-0.020 \\
(-0.028 \text { to } \\
-0.013)^{* * *}\end{array}$ & $\begin{array}{c}0.007 \\
\text { (0 to } 0.014)\end{array}$ & $\begin{array}{c}-0.005 \\
(-0.008 \text { to } \\
-0.002)^{* *}\end{array}$ & $\begin{array}{c}-0.018 \\
(-0.021 \text { to } \\
-0.015)^{* * *}\end{array}$ & $\begin{array}{c}-0.009 \\
(-0.011 \text { to } \\
-0.007)^{* * *}\end{array}$ & $\begin{array}{c}-0.013 \\
(-0.015 \text { to } \\
-0.011)^{* * *}\end{array}$ & $\begin{array}{c}0.003 \\
(-0.001 \text { to } \\
0.006)\end{array}$ & $\begin{array}{c}-0.006 \\
(-0.009 \text { to } \\
-0.002)^{* * *}\end{array}$ & $\begin{array}{l}-0.002 \\
(-0.003 \text { to } \\
-0.001)^{* *}\end{array}$ & $\begin{array}{c}-0.003 \\
(-0.004 \text { to } \\
-0.002)^{* * *}\end{array}$ \\
\hline $\begin{array}{l}\text { Sex }(\% \\
\text { females })\end{array}$ & $\begin{array}{c}0.037 \\
(0.036 \text { to } \\
0.038)^{* * *}\end{array}$ & & $\begin{array}{l}-0.015 \\
(-0.027 \text { to } \\
-0.002)^{*}\end{array}$ & & $\begin{array}{c}0.101 \\
(0.091 \text { to } \\
0.110)^{* * *}\end{array}$ & & $\begin{array}{c}0.056 \\
(0.051 \text { to } \\
0.060)^{* * *}\end{array}$ & & $\begin{array}{c}0.071 \\
(0.064 \text { to } \\
0.079)^{* * *}\end{array}$ & & $\begin{array}{c}0.052 \\
(0.050 \text { to } \\
0.054)^{* * *}\end{array}$ & \\
\hline $\begin{array}{l}\text { Age (mean } \\
\text { years) }\end{array}$ & $\begin{array}{c}0.049 \\
(0.049 \text { to } \\
0.050)^{* * * *}\end{array}$ & & $\begin{array}{c}0.070 \\
(0.059 \text { to } \\
0.080)^{* * *}\end{array}$ & & $\begin{array}{c}0.100 \\
(0.093 \text { to } \\
0.107)^{* * *}\end{array}$ & & $\begin{array}{c}0.057 \\
(0.054 \text { to } \\
0.060)^{* * *}\end{array}$ & & $\begin{array}{c}0.053 \\
(0.047 \text { to } \\
0.058)^{* * *}\end{array}$ & & $\begin{array}{c}0.041 \\
(0.039 \text { to } \\
0.043)^{* * * *}\end{array}$ & \\
\hline $\begin{array}{l}\text { Rural-urban } \\
\text { category } \\
(\text { rural=0) }\end{array}$ & $\begin{array}{c}-0.011 \\
(-0.023 \text { to } \\
0.002)\end{array}$ & & $\begin{array}{c}0.796 \\
(0.524 \text { to } \\
1.067)^{* * * *}\end{array}$ & & $\begin{array}{c}0.174 \\
(0.080 \text { to } \\
0.269)^{* * *}\end{array}$ & & $\begin{array}{c}0.010 \\
(-0.044 \text { to } \\
0.064)\end{array}$ & & $\begin{array}{c}-0.240 \\
(-0.337 \text { to } \\
-0.143)^{* * *}\end{array}$ & & $\begin{array}{c}-0.078 \\
(-0.117 \text { to } \\
-0.038)^{* * *}\end{array}$ & \\
\hline $\begin{array}{l}\text { Ethnicity } \\
\text { (\% white) }\end{array}$ & $\begin{array}{c}-0.001 \\
(-0.001 \text { to } \\
-0.001)^{* * *}\end{array}$ & & $\begin{array}{c}-0.007 \\
(-0.011 \text { to } \\
-0.003)^{* *}\end{array}$ & & $\begin{array}{c}0.009 \\
(0.006 \text { to } \\
0.012)^{* * *}\end{array}$ & & $\begin{array}{c}0.006 \\
(0.004 \text { to } \\
0.008)^{* * *}\end{array}$ & & $\begin{array}{c}0.022 \\
(0.019 \text { to } \\
0.025)^{* * *}\end{array}$ & & $\begin{array}{c}0.001 \\
(0 \text { to } \\
0.002)^{*}\end{array}$ & \\
\hline
\end{tabular}




\begin{tabular}{|c|c|c|c|c|c|c|c|c|c|c|c|c|}
\hline $\begin{array}{l}\text { Time (year } \\
\text { and month) }\end{array}$ & $\begin{array}{c}-0.053 \\
(-0.053 \text { to } \\
-0.053)^{* * *}\end{array}$ & $\begin{array}{c}-0.042 \\
(-0.042 \text { to } \\
-0.041)^{* * *}\end{array}$ & $\begin{array}{c}-0.218 \\
(-0.218 \text { to } \\
-0.218)^{* * *}\end{array}$ & $\begin{array}{c}-0.198 \\
(-0.199 \text { to } \\
-0.198)^{* * *}\end{array}$ & $\begin{array}{c}0.277 \\
(0.276 \text { to } \\
0.279)^{* * *}\end{array}$ & $\begin{array}{c}0.298 \\
(0.297 \text { to } \\
0.299)^{* * *}\end{array}$ & $\begin{array}{c}-0.094 \\
(-0.094 \text { to } \\
-0.093)^{* * *}\end{array}$ & $\begin{array}{c}-0.079 \\
(-0.080 \text { to } \\
-0.079)^{* * *}\end{array}$ & $\begin{array}{c}-0.107 \\
(-0.108 \text { to } \\
-0.106)^{* * *}\end{array}$ & $\begin{array}{c}-0.095 \\
(-0.096 \text { to } \\
-0.094)^{* * *}\end{array}$ & $\begin{array}{c}-0.035 \\
(-0.035 \text { to } \\
-0.034)^{* * *}\end{array}$ & $\begin{array}{c}-0.026 \\
(-0.026 \text { to } \\
-0.025)^{* * *}\end{array}$ \\
\hline AIC & $4,288,756$ & $4,288,756$ & 206,579 & 206,579 & 448,412 & 448,412 & $1,271,381$ & $1,271,381$ & 740,019 & 740,019 & $2,297,784$ & $2,297,784$ \\
\hline $\mathrm{BIC}$ & $4,288,867$ & $4,288,867$ & 206,691 & 206,691 & 448,523 & 448,523 & $1,271,492$ & $1,271,492$ & 740,130 & 740,130 & $2,297,895$ & $2,297,895$ \\
\hline Marginal $\mathrm{R}^{2}$ & 0.213 & 0.062 & 0.015 & 0.006 & 0.139 & 0.051 & 0.103 & 0.027 & 0.097 & 0.010 & 0.111 & 0.030 \\
\hline $\begin{array}{l}\text { Conditional } \\
\mathrm{R}^{2}\end{array}$ & 0.983 & 0.986 & 1 & 1 & 0.811 & 0.816 & 0.947 & 0.953 & 0.979 & 0.980 & 0.938 & 0.945 \\
\hline $\mathrm{N}^{\mathrm{b}}$ & \multicolumn{2}{|c|}{505,407} & \multicolumn{2}{|c|}{505,407} & \multicolumn{2}{|c|}{505,407} & \multicolumn{2}{|c|}{505,407} & \multicolumn{2}{|c|}{505,407} & \multicolumn{2}{|c|}{505,407} \\
\hline
\end{tabular}

Significance codes: *** for $\mathrm{p}<0.001 ; * *$ for $\mathrm{p}<0.01 ; *$ for $\mathrm{p}<0.05$.

AIC, Akaike information criterion; BIC, Bayesian information criterion; CCGs, Clinical Commissioning Groups; GP, general practitioner.

aThe variable time took 66 different values, from prescriptions in April 2013 where time was 2013.25 to September 2018 where time was 2018.67.

${ }^{\mathrm{b}}$ Total number of prescription entries captured in the final dataset, which includes one entry per GP practice per time point.

NOTE: Cells in the table above were greyed out if confidence intervals contained zeros. 


\section{Analysis of inequalities}

Concentration indices were in line with the previous results, further demonstrating the inequality in anti-osteoporosis drug prescription rates between the GP practices in the most and least income-deprived areas. Figure 3.3 displays examples of concentration indices, along with their concentration curves, generated for each product analysed. Over time (Figure 3.4), the results indicated an approximately equal distribution of the most frequently prescribed products (alendronic acid and risedronate sodium) across GP practices in England. On the other hand, the analysis pointed towards a disproportionate concentration of denosumab prescriptions among the least deprived populations. This inequality in the access to denosumab in favour of the least deprived increased substantially from 2013 to 2017 (with a maximum value of the CI of 0.225 in October 2016) and has remained approximately stable in the last two years $(0.202$ in September 2018). We also observed a disproportionate concentration of prescriptions among the least deprived, although to a lesser extent compared with denosumab, for ibandronic acid and raloxifene, with a CI of 0.101 and 0.088 in September 2018, respectively. Although prescribed substantially less frequently than other anti-osteoporosis drugs, the prescriptions of the combined alendronic acid and colecalciferol were slightly concentrated among the most deprived populations (a minimum CI of -0.091 in May 2016). 
Figure 3.3. Concentration curves of anti-osteoporosis drugs using prescribing data from GP practices in England in September 2018.
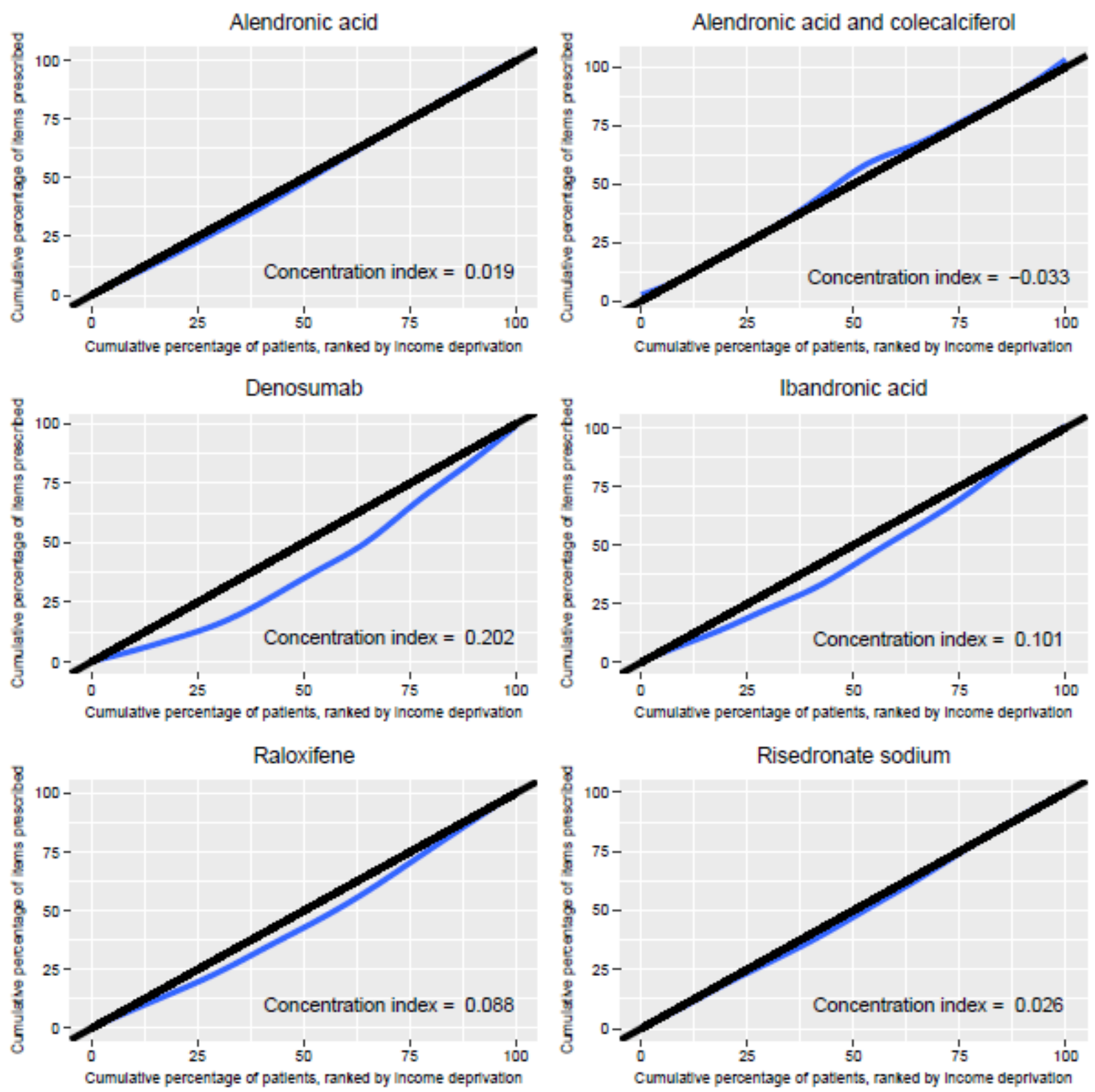
Figure 3.4. Concentration index (calculated with the patient population ranked by income deprivation of the LSOA where the GP practice is based) over time.

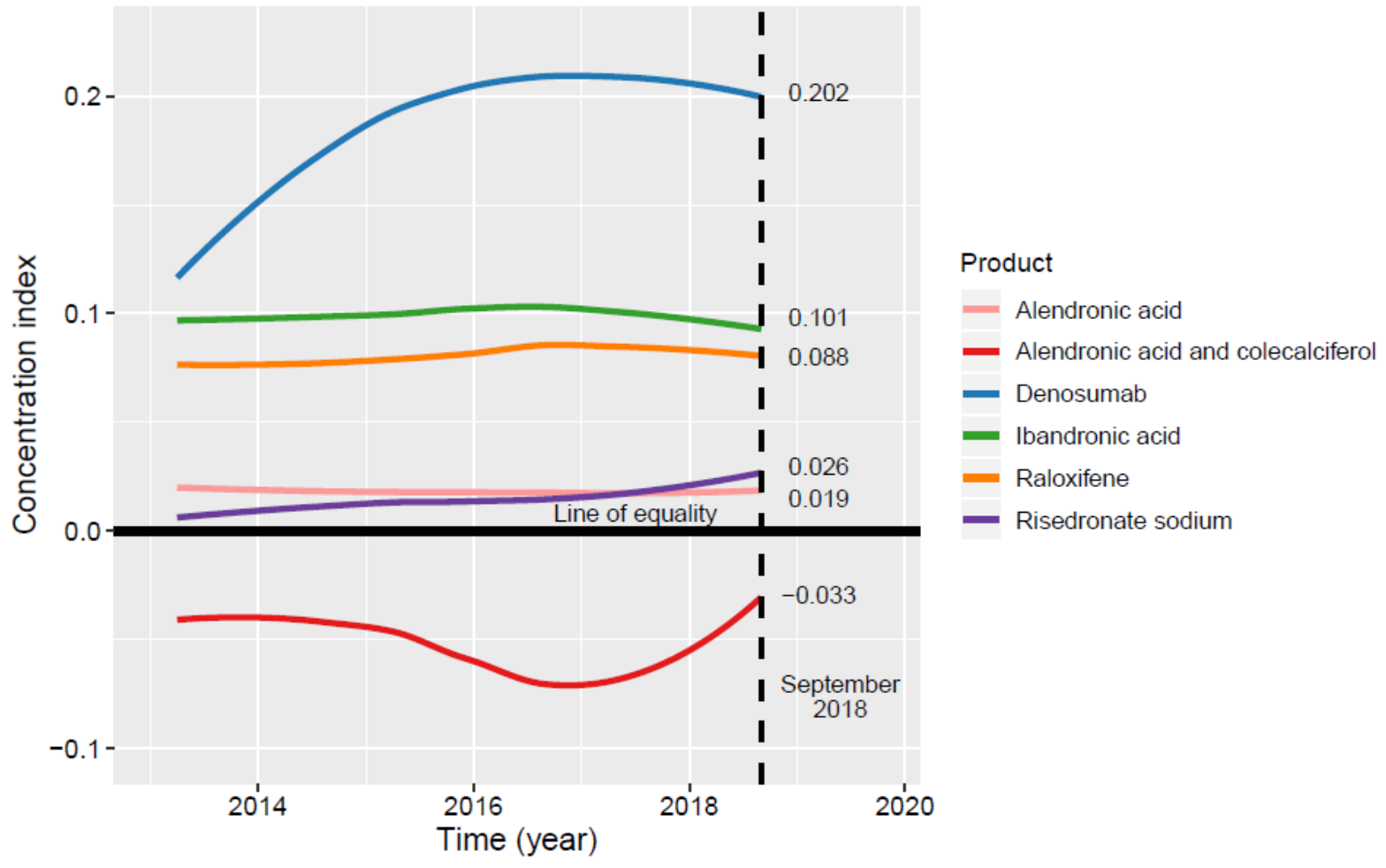

\section{DISCUSSION}

\section{Summary of findings}

Firstly, our analyses showed that alendronic acid is by far the most frequently prescribed anti-osteoporosis drug, followed by risedronate sodium and ibandronic acid. However, the prescription levels of all anti-osteoporosis drugs analysed here, except for denosumab, have been falling over the past few years. Secondly, we demonstrated that demographic and socio-economic characteristics (i.e. sex, age, ethnic group composition, rural-urban classification and income deprivation of the local area) of the patients being served do have an impact on anti-osteoporosis drug prescription rates. Our results revealed that income deprivation, a key variable in our analyses, had a negative effect on prescription levels of alendronic acid (with and without colecalciferol), denosumab, ibandronic acid and risedronate sodium; the case of denosumab represents the clearest example, exhibiting a steep surge in prescription rates across GPs located in the least income-deprived areas, compared with a modest rise in the most income-deprived areas. Also, our results suggested that different prescribing behaviours may exist across GPs according to the CCG to which they belong. Finally, the CIs corroborated the association of income deprivation with drug prescription levels. The concentration index was positive for denosumab, ibandronic acid and raloxifene, showing that prescriptions of these drugs were disproportionately concentrated among 
the least deprived. The CI associated with denosumab showed a sharp increase since the first prescriptions in 2013 and remained relatively stable at a value slightly over 0.2 since 2017.

\section{Strengths and limitations}

The UK Government have done an excellent job in making many large datasets freely available to the public. This exemplifies an unprecedented exercise of transparency that can lead to generating valuable insights such as those exposed in this paper. For privacy reasons, however, all these datasets capture aggregated data rather than patient-level data, which would potentially result in more precise estimations. Nevertheless, we consider that the granularity of the prescriptions by GPs and the combination with other variables from various sources is a key strength of our analysis and represents a unique recipe that could trigger potentially controversial discussions at all levels of society.

Our study had some limitations. The lack of individual patient-level data prevented us from assessing the impact of other potential confounders such as patients' characteristics (e.g. fracture history or comorbidities), compliance or persistence. Also, due to the lack of a robust evidence base and consensus among experts, the implementation of the socalled "drug holidays" may vary across GP practices in England [43, 44]. Drug holidays may influence anti-osteoporosis drug prescription rates, but the absence of these data in publicly available datasets did not allow us to assess its impact. Likewise, the inability to track treatment switches precluded us from analysing the variation of antiosteoporosis treatment patterns in more detail. Between April 2013 and January 2017 only quarterly data describing the patient population were available (as opposed to monthly data thereafter) and therefore, to estimate the data for the missing months, we assumed a linear change between the two closest data points available. Considering that exceptional changes in the size, sex and age structure of a GP practice are unlikely to happen from month to month, we believe this approach is realistic. Also, these data were unavailable for small GP practices (generally practices with less than 100 registered patients) for privacy reasons. Apart from being an unavoidable limitation, we do not believe this to be a source of bias. The GP list inflation, which may be caused by patients who should have but have not been removed from GP lists (following death or emigration, for example), poses another challenge for the interpretation of our analyses. This is an issue the UK Government have been trying to address for years, but the problem still exists and constitutes a limitation we could not circumvent.

On the other hand, rural-urban classification, ethnicity and income deprivation data were only available at a single point in time. This represents a considerable, albeit 
unavoidable, limitation. A recent study, however, showed that the general patterns of overall and health-related deprivation patterns have persisted in England since 2004 and therefore we do not believe that our results were affected by the lack of more up-to-date data in any significant way [45]. Additionally, our analysis combined data for GP practices with data of the corresponding neighbourhood. For this, we assumed that patients registered with a GP practice live in the vicinity of that GP practice. This is a reasonable assumption given how patients have been registered and accepted by GP practices historically but may not be necessarily correct since 2015 when the NHS announced that GP practices were free to register patients that live outside their practice boundary area [46]. Another key caveat worth mentioning is that the IMD, and its income deprivation domain, are designed to identify aspects of deprivation rather than affluence; e.g. being among the least deprived does not necessarily mean being among the wealthiest. It is important to keep this in mind when interpreting the results. For the calculation of concentration indices, we compared the distribution of each of the antiosteoporosis drugs analysed here with the 45-degree line, or the equality line. By doing so we assumed that the right thing would be for all GP practices to prescribe all drugs at the same rates regardless of the characteristics of the population being served. This may be a considerable limitation but, nevertheless, allows us to draw clear conclusions regarding the trends in inequalities associated with anti-osteoporosis drug prescription rates by GPs in England.

\section{Comparison with other studies}

Our results are aligned with those reported by many others indicating that key demographic and socio-economic variables have a significant impact on varying prescription rates. Antibiotics represent one of the most frequently analysed drug groups when it comes to geographic variation in prescription rates within and across healthcare settings. For example, several studies have shown varying antibiotic prescription rates in Italian children which follow the well-described north-south socio-economic polarisation according to income and HDI; [11, 14, 16, 47] studies in other jurisdictions have drawn similar conclusions [4, 8, 9, 48-50]. Many other disease areas (e.g. glaucoma or mental health disorders), although perhaps to a lesser extent, have also been investigated and reported comparable findings $[6,10,12,13,51]$.

Several studies have analysed the prescription trends and determinants of antiosteoporosis prescriptions in the UK. One study examined the patterns and determinants of anti-osteoporosis drug prescriptions after hip fracture between 2000 and 2010 using patient-level data from clinical records from the Clinical Practice Research Datalink (CPRD) database [52]. The study showed a steady rise in prescriptions during the study 
period and indicated an increased likelihood of prescriptions for females, older ages or history of major osteoporotic fractures, among other variables [52]. Another study, also using patient-level data from the CPRD, analysed the prescription rates of antiosteoporosis drugs in the UK between 1990 and 2012, and the analyses were stratified by sex, age, geographic region and ethnicity [15]. The study exposed a plateau, or even a decrease in the case of women, in prescription rates at the end of the study period, and demonstrated there were marked differences between ethnic groups and regions [15]. These studies confirm that our selection of covariates was appropriate. A key strength of these studies was the use of patient-level data from CPRD, which allowed linking patient-specific characteristics with prescriptions, whereas we had to used aggregated data that did not allow the same level of granularity in the analyses.

Another recent study that used the same data sources as we did, analysed the variation in gluten-free prescription rates at the GP level in England [39]. The authors found CCGs to be a significant driver of variation, with a large variation in gluten-free prescribing at the CCG level and a significant effect of CCGs in their statistical models. These results, the authors said, were likely due to variations in CCG policies, suggesting that practices are responsive to CCG prescribing guidance. Our results are aligned with the findings reported for gluten-free foods, which reassures the appropriateness of our approach.

\section{Policy-level implications}

There may be cases in which certain inequalities in drug prescription rates can be considered fair. For instance, some genetic diseases may follow a singular geo-spatial pattern, which in turn generates geo-spatial differences in the distribution of resources deployed to treat these particular diseases [53, 54]. In general, however, very strict conditions need to be met for regarding inequalities as fair, and we do not see any reason why certain anti-osteoporosis prescriptions should be disproportionately concentrated in given areas [2]. Published meta-analyses have claimed that no statistically significant differences exist among the anti-osteoporosis drugs currently used for the prevention of hip-fractures and therefore there is no clear basis for the existence of distinct prescription patterns, such as those observed in Figure 3.2 [55-57]. The implications of varying patterns are even more remarkable considering the price differences among these products (Online Resource, Appendix 1). Denosumab is a pricy drug compared with the other drugs included in these analyses and, from a healthcare policymaker's perspective, it may be worrying to realise that a patient registered with a GP in a relatively deprived area may be less likely to receive denosumab compared with a patient in a less deprived area. Also, we showed that prescription levels may be associated with the corresponding CCG, meaning that funding decisions made at the CCG level may be affecting 
prescription levels downstream. With these results, our analyses added further evidence to the postcode lottery issue [39].

According to the GP contract, GPs get the largest proportion of their income from the "Global sum", i.e. capitation-based payments adjusted by factors such as patients' age and gender, as well as the morbidity and mortality in the local area. Also, since 2004, the Quality and Outcomes Framework (QOF) represents a substantial proportion of GPs' total income [58]. The QOF is a voluntary reward and incentive programme to promote an evidence-based, high-quality care in England [59]. Rewards are granted according to a point-based system; out of 379 points in the clinical domain, 3 correspond to indicators of secondary prevention of fragility fractures associated with osteoporosis [59]. All GPs across England are assessed against the same indicators and therefore we do not see any reason why the QOF may affect GPs' prescribing behaviour. Also, because treatments prescribed by GPs are paid for by the NHS (except a $£ 9$ per-item patient co-payment) there seems to be no personal economic incentive for GPs to prescribe one drug or another. Additionally, GPs are constantly monitored by CCGs' Medicines Management Teams, who ensure that the latest medical guidance is followed and the most costeffective treatments are used.

Understanding the association between demographic and socio-economic variables and prescription rates of anti-osteoporosis drugs, as presented in our study, is key for designing strategies to tackle inequality and ensure an efficient allocation of resources, as stated by the Astana Declaration on primary health care [20,60]. Attaining the highest possible standard of care is a fundamental right of every human being and for that the international community agreed on a clear set of Sustainable Development Goals, which include good health and wellbeing, as well as reduced inequalities, decades ago. Therefore, it should be expected that healthcare authorities have effective policies in place to incentivise an evidence-based use of resources to avoid misuse and unnecessary costs, as well as distributing the resources available on the basis of the needs of the particular populations served [61]. This is of even greater importance in light of studies that have estimated that a significant proportion of patients (30-40\% worldwide) do not receive treatments of proven effectiveness, and that 20-25\% receive unnecessary or even harmful treatments [62]. Our study sheds light on the existing inequalities in the English primary health care and presents evidence that, hopefully, will guide decision-makers towards a fairer and more efficient health system.

\section{Future research}

The true reasons for the existence of different prescribing behaviours across GP 
practices are still unclear to us. There are diseases in which treatment selection may be guided by policy according to certain patient characteristics, but NICE guidelines for osteoporosis treatment (including the guidance on bisphosphonates updated in July 2019) are clear: oral and intravenous bisphosphonates are recommended in England, within their marketing authorisations, for treating osteoporosis in adults at a high risk of osteoporotic fragility fracture and when treatment is appropriate, considering the risk of fracture, risk of adverse events, and other clinical circumstances or preferences [28]. In other words, no patient characteristic other than fracture risk scores should be affecting treatment selection [28].

A recent study in the United States concluded that patients' socio-economic status influences physician price responses but it is unclear whether this could be the case in a publicly funded system such as the NHS in England [63]. Another potential factor influencing treatment selection across GPs, therefore, could be the distribution of fracture risk scores across the English geography. Similarly, we showed that considering varying prescription levels by CCG had a substantial impact on results. Because GP funding decisions are made at the CCG level, we believe that different policies at different CCGs may be considerably influencing GPs' prescription decisions. Other factors with a potentially significant effect on prescribing patterns may be patients' perceptions and the associated GPs' prescription attitudes and the familiarity of GPs with anti-osteoporosis drugs, which may also be related to the power of the workforce pharmaceutical companies deploy throughout the country. All these remain fields that requires further study, but the ongoing NICE appraisal on non-bisphosphonates for treating osteoporosis may clarify some of the uncertainties associated with treatment selection described here. The current analysis could also be expanded to analyse prescription rates of other treatments and understand whether similar patterns exist across disease areas.

\section{CONCLUSIONS}

Variation in the prescription of anti-osteoporosis drugs exists across GPs and CCGs in England, this being more prominent for certain drugs (e.g. denosumab and ibandronic acid) compared with others (e.g. alendronic acid). Inequalities exist in English primary healthcare and we advocate our findings could support the efforts of decision-makers towards a more equitable system.

\section{CONTRIBUTORS}

All authors (IA, ESI, GLDT and JMC) conceptualised and designed the work; IA collected, cleaned and analysed the data; all authors interpreted the data; IA drafted the 
manuscript. All authors revised the work and approved the final version of the manuscript submitted for publication. The corresponding author confirms that all listed authors meet authorship criteria and that no others meeting the criteria have been omitted.

\section{FUNDING SOURCE}

This research did not receive any specific grant from funding agencies in the public, commercial, or non-for-profit sectors.

\section{DECLARATION OF INTEREST}

All authors have completed the ICMJE conflict of interest form and declare: no support from any organisation for the submitted work; IA and GLDT were Amgen employees during a period prior to the manuscript submission date; ESI and JMC declare no financial relationships with any organisations that might have an interest in the submitted work; no other relationships or activities that could appear to have influenced the submitted work. 


\section{REFERENCES}

1. World Health Organization: Constitution of the World Health Organization. In. (1948)

2. Kawachi, I., Subramanian, S.V., Almeida-Filho, N.: A glossary for health inequalities. J. Epidemiol. Community Health 56(9), 647-652 (2002).

3. European Centre for Disease Prevention and Control: Geographical distribution of antimicrobial consumption. https://ecdc.europa.eu/en/antimicrobial-consumption/database/geographical-distribution (2007). Accessed October 12 2017

4. Goossens, H., Ferech, M., Vander Stichele, R., Elseviers, M.: Outpatient antibiotic use in Europe and association with resistance: a cross-national database study. Lancet (London, England) 365(9459), 579-587 (2005). Doi:10.1016/s01406736(05)17907-0

5. Hartz, I., Sakshaug, S., Furu, K., Engeland, A., Eggen, A.E., Njolstad, I., Skurtveit, S.: Aspects of statin prescribing in Norwegian counties with high, average and low statin consumption - an individual-level prescription database study. BMC Clin. Pharmacol. 7, 14 (2007). Doi:10.1186/1472-6904-7-14

6. Heng, J.S., Wormald, R., Khaw, P.T.: Geographical variation in glaucoma prescribing trends in England 2008-2012: an observational ecological study. BMJ open 6(5), e010429 (2016). Doi:10.1136/bmjopen-2015-010429

7. House, S.A., Goodman, D.C., Weinstein, S.J., Chang, C.H., Wasserman, J.R., Morden, N.E.: Prescription Use among Children with Autism Spectrum Disorders in Northern New England: Intensity and Small Area Variation. J. Pediatr. 169, 277-283.e272 (2016). Doi:10.1016/j.jpeds.2015.10.027

8. Koller, D., Hoffmann, F., Maier, W., Tholen, K., Windt, R., Glaeske, G.: Variation in antibiotic prescriptions: is area deprivation an explanation? Analysis of 1.2 million children in Germany. Infect. 41(1), 121-127 (2013). Doi:10.1007/s15010-012-0302-1

9. Mangrio, E., Wremp, A., Moghaddassi, M., Merlo, J., Bramhagen, A.C., Rosvall, M.: Antibiotic use among 8-month-old children in Malmo, Sweden-in relation to child characteristics and parental sociodemographic, psychosocial and lifestyle factors. BMC Pediatr. 9, 31 (2009). Doi:10.1186/1471-2431-9-31

10. Morrison, J., Anderson, M.J., Sutton, M., Munoz-Arroyo, R., McDonald, S., Maxwell, M., Power, A., Smith, M., Wilson, P.: Factors influencing variation in prescribing of antidepressants by general practices in Scotland. The British J. Gen. Pract. 59(559), e25-31 (2009). Doi:10.3399/bjgp09X395076

11. Piovani, D., Clavenna, A., Cartabia, M., Bonati, M.: The regional profile of antibiotic prescriptions in Italian outpatient children. Eur. J. Clin. Pharmacol. 68(6), 997-1005 (2012). Doi:10.1007/s00228-011-1204-3

12. Zakarias, J.K., Jensen-Dahm, C., Norgaard, A., Stevnsborg, L., Gasse, C., Andersen, B.G., Soren, J., Waldorff, F.B., Moos, T., Waldemar, G.: Geographical Variation in Antipsychotic Drug Use in Elderly Patients with Dementia: A Nationwide Study. J. Alzheimer's Dis. : JAD 54(3), 1183-1192 (2016). Doi:10.3233/jad-160485

13. Islam, M.M., McRae, I.S., Mazumdar, S., Simpson, P., Wollersheim, D., Fatema, K., Butler, T.: Prescription opioid dispensing in New South Wales, Australia: spatial and temporal variation. BMC Pharmacol. Toxicol. 19(1), 30 (2018). Doi:10.1186/s40360-018-0219-0

14. Di Martino, M., Lallo, A., Kirchmayer, U., Davoli, M., Fusco, D.: Prevalence of antibiotic prescription in pediatric outpatients in Italy: the role of local health districts and primary care physicians in determining variation. A multilevel 
design for healthcare decision support. BMC public health 17(1), 886 (2017). Doi:10.1186/s12889-017-4905-4

15. van der Velde, R.Y., Wyers, C.E., Teesselink, E., Geusens, P., van den Bergh, J.P.W., de Vries, F., Cooper, C., Harvey, N.C., van Staa, T.P.: Trends in oral anti-osteoporosis drug prescription in the United Kingdom between 1990 and 2012: Variation by age, sex, geographic location and ethnicity. Bone 94, 50-55 (2017). Doi:10.1016/j.bone.2016.10.013

16. Piovani, D., Clavenna, A., Cartabia, M., Bonati, M.: Antibiotic and anti-asthmatic drug prescriptions in Italy: geographic patterns and socio-economic determinants at the district level. Eur. J. Clin. Pharmacol. 70(3), 331-337 (2014).

Doi:10.1007/s00228-013-1615-4

17. Cingano, F.: Trends in Income Inequality and its Impact on Economic Growth. In: Publishing, O. (ed.) OECD Social, Employment and Migration Working Papers, vol. 163. Paris, (2014)

18. Stronks, G., Gunning-Schepers, L.J.: Should equity in health be target number 1. Eur. J. Public Health (65), 153-165.

19. Watkins, K.: Saving lives with equity-the efficient route to the SDGs. Lancet (London, England) 390(10092), 339-340 (2017). Doi:10.1016/s0140-6736(17)31873-1

20. Hone, T., Macinko, J., Millett, C.: Revisiting Alma-Ata: what is the role of primary health care in achieving the Sustainable Development Goals? Lancet (London, England) 392(10156), 1461-1472 (2018). Doi:10.1016/s01406736(18)31829-4

21. National Clinical Guideline Centre: Osteoporosis: fragility fracture risk. Short clinical guideline - CG146. Evidence and recommendations. https://www.nice.org.uk/guidance/cg146/evidence/full-guideline-pdf-186818365 (2012). Accessed November $28^{\text {th }} 2018$

22. National Institute for Health and Care Excellence: NICE impact. Falls and fragility fractures. https://www.nice.org.uk/media/default/about/what-we-do/into-practice/measuring-uptake/nice-impact-falls-and-fragilityfractures.pdf (2018). Accessed November $28^{\text {th }} 2018$

23. Gauthier, A., Kanis, J.A., Jiang, Y., Martin, M., Compston, J.E., Borgstrom, F., Cooper, C., McCloskey, E.V.: Epidemiological burden of postmenopausal osteoporosis in the UK from 2010 to 2021: estimations from a disease model. Arch. Osteoporos. 6, 179-188 (2011). Doi:10.1007/s11657-011-0063-y

24. National Institute for Health and Care Excellence: Raloxifene and teriparatide for the secondary prevention of osteoporotic fragility fractures in postmenopausal women. Technology appraisal guidance [TA161]. https://www.nice.org.uk/guidance/ta161 (2008). Accessed November $11^{\text {th }} 2018$

25. National Institute for Health and Care Excellence: Raloxifene for the primary prevention of osteoporotic fragility fractures in postmenopausal women. Technology appraisal guidance [TA160]. https://www.nice.org.uk/guidance/ta160 (2008). Accessed November $23^{\text {rd }} 2018$

26. National Institute for Health and Care Excellence: Denosumab for the prevention of osteoporotic fractures in postmenopausal women. https://www.nice.org.uk/guidance/ta204 (2010). Accessed November $23^{\text {rd }} 2018$

27. National Institute for Health and Care Excellence: Bisphosphonates for preventing osteoporotic fragility fractures (including a partial update of NICE technology appraisal guidance 160 and 161). Final scope. https://www.nice.org.uk/guidance/ta464/documents/osteoporosis-prevention-bisphosphonates-inc-part-rev-ta160-ta161id782-final-scope2 (2014). Accessed November $23^{\text {rd }} 2018$

28. National Institute for Health and Care Excellence: Bisphosphonates for treating osteoporosis. Technology appraisal guidance [TA464]. https://www.nice.org.uk/guidance/ta464 (2017). Accessed October $9^{\text {th }} 2019$

29. NHS Digital: Supporting open data and transparency. http://content.digital.nhs.uk/services/transparency. Accessed 
September $19^{\text {th }} 2017$

30. Health and Social Care Information Centre: General Practice Prescribing Data. Frequently Asked Questions. In. (2015)

31. NHS Digital: Practice Level Prescribing Data. https://digital.nhs.uk/data-and-information/publications/statistical/practicelevel-prescribing-data (2018). Accessed November $\left.23^{\text {rd }} 2018\right]$

32. NHS Digital: Numbers of Patients Registered at a GP Practice (practice level, 5 year age groups). https://data.gov.uk/dataset/numbers_of_patients_registered_at_a_gp_practice (2018). Accessed September $19^{\text {th }} 2018$

33. Office for National Statistics: 2011 Census Data On Nomis. http://www.nomisweb.co.uk/census/2011. Accessed January $10^{\text {th }} 2018$

34. Office for National Statistics: Rural Urban Classification (2011) of Lower Layer Super Output Areas in England and Wales.

http://geoportal.statistics.gov.uk/datasets/276d973d30134c339eaecfc3c49770b3_0/data?selectedAttribute=RUC11. Accessed November $23^{\text {rd }} 2018$

35. Government Digital Service: English indices of deprivation. https:/www.gov.uk/government/statistics/english-indices-ofdeprivation-2015 (2015). Accessed January 102018

36. EBM DataLab, University of Oxford: OpenPrescribing.net. https://openprescribing.net/ (2017). Accessed January $26^{\text {th }}$ 2018

37. Amgen UK Ltd: Denosumab for the prevention of osteoporotic fractures in postmenopausal women. https://www.nice.org.uk/guidance/ta204/documents/osteoporotic-fractures-denosumab-manufacturer-submission2 (2010). Accessed November $23^{\text {rd }} 2018$

38. Iacobucci, G.: Patients with type 1 diabetes are missing out on flash glucose devices, finds BMJ investigation. BMJ (Clinical research ed.) 363, k4675 (2018). Doi:10.1136/bmj.k4675

39. Walker, A.J., Curtis, H.J., Bacon, S., Croker, R., Goldacre, B.: Trends, geographical variation and factors associated with prescribing of gluten-free foods in English primary care: a cross-sectional study. BMJ open 8(3), e021312 (2018). Doi:10.1136/bmjopen-2017-021312

40. Nakagawa, S., Schielzeth, H.: A general and simple method for obtaining R2 from Generalized Linear Mixed-effects Models. Methods Ecol. Evol. 4, 133-142 (2012). Doi:10.1111/j.2041-210x.2012.00261.x

41. O’Donnell, O., van Doorslaer, E., Wagstaff, A., Lindelow, M.: Analyzing Health Equity Using Household Survey Data. http://siteresources.worldbank.org/INTPAH/Resources/Publications/459843-1195594469249/HealthEquityFINAL.pdf (2008). Accessed November $\left.26^{\text {th }} 2018\right]$

42. The R Foundation: The R Project for Statistical Computing. https://www.r-project.org/ (2018).

43. Adams, A.L., Adams, J.L., Raebel, M.A., Tang, B.T., Kuntz, J.L., Vijayadeva, V., McGlynn, E.A., Gozansky, W.S.: Bisphosphonate Drug Holiday and Fracture Risk: A Population-Based Cohort Study. J. Bone Miner. Res. 33(7), 12521259 (2018). Doi:10.1002/jbmr.3420

44. Anagnostis, P., Paschou, S.A., Mintziori, G., Ceausu, I., Depypere, H., Lambrinoudaki, I., Mueck, A., Perez-Lopez, F.R., Rees, M., Senturk, L.M., Simoncini, T., Stevenson, J.C., Stute, P., Tremollieres, F.A., Goulis, D.G.: Drug holidays from bisphosphonates and denosumab in postmenopausal osteoporosis: EMAS position statement. Maturitas 101, 23-30 (2017). Doi:10.1016/j.maturitas.2017.04.008

45. Kontopantelis, E., Mamas, M.A., van Marwijk, H., Ryan, A.M., Buchan, I.E.: Geographical epidemiology of health and overall deprivation in England, its changes and persistence from 2004 to 2015: a longitudinal spatial population study. 
72(2), 140-147 (2018). Doi:10.1136/jech-2017-209999

46. England, N.: Patient choice of GP practices. https://www.nhs.uk/using-the-nhs/nhs-services/gps/patient-choice-of-gppractices/ (2018). Accessed April $8^{\text {th }} 2019$

47. Moro, M.L., Marchi, M., Gagliotti, C., Di Mario, S., Resi, D.: Why do paediatricians prescribe antibiotics? Results of an Italian regional project. BMC Pediatr. 9, 69 (2009). Doi:10.1186/1471-2431-9-69

48. Filippini, M., Masiero, G., Moschetti, K.: Socioeconomic determinants of regional differences in outpatient antibiotic consumption: evidence from Switzerland. Health policy (Amsterdam, Netherlands) 78(1), 77-92 (2006).

Doi:10.1016/j.healthpol.2005.09.009

49. Jung, Y., Cho, H., Ji, E., Park, E.J., Jang, S.: Geographic variations in antibiotic prescription for pediatric acute upper respiratory tract infections in South Korea. Int. J. Clin. Pharmacol. Therapeutics 56(4), 177-183 (2018).

Doi:10.5414/cp203032

50. Nitzan, O., Low, M., Lavi, I., Hammerman, A., Klang, S., Raz, R.: Variability in outpatient antimicrobial consumption in Israel. Infect. 38(1), 12-18 (2010). Doi:10.1007/s15010-009-9065-8

51. Saeed, H.S., Wright, R.B., Ghosh, S.K.: Trends in the prescribing of topical nasal agents Using an NHS England data base. Clin. Otolaryngol. 43(5), 1296-1302 (2018). Doi:10.1111/coa.13143

52. Klop, C., Gibson-Smith, D., Elders, P.J., Welsing, P.M., Leufkens, H.G., Harvey, N.C., Bijlsma, J.W., van Staa, T.P., de Vries, F.: Anti-osteoporosis drug prescribing after hip fracture in the UK: 2000-2010. Osteoporos. Int. 26(7), 1919-1928 (2015). Doi:10.1007/s00198-015-3098-x

53. Laberge, A.M.: [Prevalence and distribution of genetic diseases in Quebec: impact of the past on the present]. Medecine sciences : M/S 23(11), 997-1001 (2007). Doi:10.1051/medsci/20072311997

54. Organization, W.H.: Genomic resource centre. Genes and human disease. http://www.who.int/genomics/public/geneticdiseases/en/index2.html. Accessed October 122017

55. Albert, S.G., Reddy, S.: CLINICAL EVALUATION OF COST EFFICACY OF DRUGS FOR TREATMENT OF OSTEOPOROSIS: A META-ANALYSIS. Endocr. Pract. 23(7), 841-856 (2017). Doi:10.4158/ep161678.ra

56. Khalid, S., Calderon-Larranaga, S., Hawley, S., Ali, M.S., Judge, A., Arden, N., van Staa, T., Cooper, C., Javaid, M.K., Prieto-Alhambra, D.: Comparative anti-fracture effectiveness of different oral anti-osteoporosis therapies based on "realworld" data: a meta-analysis of propensity-matched cohort findings from the UK Clinical Practice Research Database and the Catalan SIDIAP Database. Clin. Epidemiol. 10, 1417-1431 (2018). Doi:10.2147/clep.s164112

57. Wu, J., Zhang, Q., Yan, G., Jin, X.: Denosumab compared to bisphosphonates to treat postmenopausal osteoporosis: a meta-analysis. J. Orthop. Surg. Res. 13(1), 194 (2018). Doi:10.1186/s13018-018-0865-3

58. Addicott, R., Ham, C.: Commissioning and funding general practice. https://www.kingsfund.org.uk/sites/default/files/field/field_publication_file/commissioning-and-funding-general-practicekingsfund-feb14.pdf (2014). Accessed October $9^{\text {th }} 2019$

59. Group, P.C.S.a.N.C.: 2019/20 General Medical Services (GMS) contract Quality and Outcomes Framework (QOF). https://www.england.nhs.uk/wp-content/uploads/2019/05/gms-contract-qof-guidance-april-2019.pdf (2019). Accessed October $9^{\text {th }} 2019$

60. World Health Organization: Declaration of Astana. https://www.who.int/docs/default-source/primaryhealth/declaration/gcphc-declaration.pdf (2018). Accessed April $8^{\text {th }} 2019$

61. NHS England, Transformation and Corporate Operations - Business Planning Team: NHS England Business Plan. 
https://www.england.nhs.uk/wp-content/uploads/2016/03/bus-plan-16.pdf (2016). Accessed April $8^{\text {th }} 2019$

62. Elshaug, A.G., Watt, A.M., Moss, J.R., Hiller, J.E.: Policy perspectives on the obsolescence of health technologies in Canada. Discussion paper. In. (2009)

63. Chen, A., Lakdawalla, D.N.: Healing the poor: The influence of patient socioeconomic status on physician supply responses. J. Health Econ. 64, 43-54 (2019). Doi:10.1016/j.jhealeco.2019.02.001 


\section{Appendix 1: Anti-osteoporosis drug costs.}

\begin{tabular}{|l|l|l|l|l|l|}
\hline & $\begin{array}{l}\text { Generic } \\
\text { available? }\end{array}$ & $\begin{array}{l}\text { Items per } \\
\text { pack and } \\
\text { dose per } \\
\text { item }\end{array}$ & $\begin{array}{l}\text { Price per } \\
\text { pack }\end{array}$ & $\begin{array}{l}\text { Cost per } \\
\text { annum }\end{array}$ & Source \\
\hline $\begin{array}{l}\text { Alendronic } \\
\text { acid (oral) }\end{array}$ & Yes & $4 \times 70 \mathrm{mg}$ & $£ 0.87$ & $£ 11.34$ & TA464 \\
\hline $\begin{array}{l}\text { Denosumab } \\
\text { (subcutaneous) }\end{array}$ & No & $\begin{array}{l}1 \times 60 \\
\mathrm{mg} / \mathrm{ml}\end{array}$ & $£ 183.00$ & $£ 366.00$ & $\begin{array}{l}\text { MIMS } \\
\text { online }\end{array}$ \\
\hline $\begin{array}{l}\text { Ibandronic } \\
\text { acid } \\
\text { (intravenous) }\end{array}$ & Yes & $1 \times 150 \mathrm{mg}$ & $£ 1.32$ & $£ 15.84$ & TA464 \\
\hline $\begin{array}{l}\text { Ibandronic } \\
\text { acid (oral) }\end{array}$ & Yes & $\begin{array}{l}1 \times 3 \mathrm{mg} / 3 \\
\mathrm{ml}\end{array}$ & $£ 8.51$ & $£ 34.04$ & TA464 \\
\hline Raloxifene & Yes & $28 \times 60 \mathrm{mg}$ & $£ 3.49$ & $£ 45.49$ & $\begin{array}{l}\text { MIMS } \\
\text { online }\end{array}$ \\
\hline $\begin{array}{l}\text { Risedronate } \\
\text { sodium }\end{array}$ & Yes & $4 \times 35 \mathrm{mg}$ & $£ 0.98$ & $£ 12.78$ & TA464 \\
\hline
\end{tabular}

MIMS, Monthly Index of Medical Specialties; TA464, technology appraisal 464. NOTES:

- These prices are estimates of the actual prices paid by the English National Health Service.

- The costs for alendronic acid, ibandronic acid and risedronate sodium were collected from the TA464 guidance issued by NICE (Committee Papers; Table 3). ${ }^{1}$

- The costs of denosumab and raloxifene were estimated using the price per pack from MIMS online (www.mims.co.uk), accessed on April $7^{\text {th }}, 2019$.

\footnotetext{
${ }^{1}$ National Institute for Health and Care Excellence. Denosumab for the prevention of osteoporotic fractures in postmenopausal women 2010 [Available from: https://www.nice.org.uk/guidance/ta204, accessed November $23^{\text {rd }} 2018$ ].
} 


\section{Appendix 2: Products excluded from the analysis and the reason for their exclusion.}

\begin{tabular}{|c|c|c|}
\hline Product & $\begin{array}{l}\text { Mode of } \\
\text { administration }\end{array}$ & Reason for exclusion \\
\hline $\begin{array}{l}\text { Denosumab } \\
\text { XGEVA } \AA\end{array}$ & $\mathrm{SC}$ & $\begin{array}{l}\text { Denosumab exists as two branded products: Prolia }{ }^{\circledR} \\
\text { and XGEVA } ₫ \text {. XGEVA } ® \text { is indicated for the } \\
\text { prevention of skeletal related events in adults with } \\
\text { advanced malignancies involving bone, which is } \\
\text { outside the scope of the current analysis. }\end{array}$ \\
\hline $\begin{array}{l}\text { Etidronate } \\
\text { disodium }\end{array}$ & Oral & $\begin{array}{l}\text { Etidronate disodium was not included as a comparator } \\
\text { in the NICE TA } 464 \text { final scope as it had been } \\
\text { discontinued by the manufacturer in the UK despite } \\
\text { having a UK marketing authorisation for the prevention } \\
\text { and treatment of corticosteroid-induced osteoporosis. } \\
\text { Additionally, prescription datasets show that less than } \\
10 \text { items per month have been prescribed by GPs in the } \\
\text { England since January } 2015 .^{3}\end{array}$ \\
\hline $\begin{array}{l}\text { Other } \\
\text { bisphosphonate } \\
\text { and other } \\
\text { preparations }\end{array}$ & - & $\begin{array}{l}\text { This category represents a mix of rarely prescribed } \\
\text { items, with less than } 100 \text { items prescribed per month in } \\
\text { England since, at least, October } 2013 .^{3}\end{array}$ \\
\hline $\begin{array}{l}\text { Pamidronate } \\
\text { disodium }\end{array}$ & IV & $\begin{array}{l}\text { Pamidronate disodium was not included as a } \\
\text { comparator in the NICE TA guidance } 160,161 \text { and } 204 \text {, } \\
\text { nor included in the TA464 final scope. }{ }^{2} \text { Also, by being a } \\
\text { product administered intravenously, it is unlikely to be } \\
\text { prescribed in primary care. Eight items or less per } \\
\text { month have been prescribed by GPs in England since } \\
\text { October } 2013 .{ }^{3}\end{array}$ \\
\hline $\begin{array}{l}\text { Strontium } \\
\text { ranelate }\end{array}$ & Oral & $\begin{array}{l}\text { There has been a sharp decline in the number of GP } \\
\text { prescriptions of strontium ranelate over time in } \\
\text { England, with less than } 100 \text { prescriptions in September } \\
2018 .^{3}\end{array}$ \\
\hline Tiludronic acid & IV & $\begin{array}{l}\text { No items have been prescribed by GPs in England since } \\
\text { October } 2013 .^{3}\end{array}$ \\
\hline
\end{tabular}

\footnotetext{
2 National Institute for Health and Care Excellence. Bisphosphonates for preventing osteoporotic fragility fractures (including a partial update of NICE technology appraisal guidance 160 and 161). Final scope. 2014 [Available from:

https://www.nice.org.uk/guidance/ta464/documents/osteoporosis-prevention-bisphosphonates-inc-part-rev-ta160-ta161-id782-final-scope2, accessed November 23 $\left.3^{\text {rd }} 2018\right]$

3 EBM DataLab, University of Oxford. OpenPrescribing.net 2017 [Available from: https://openprescribing.net/, accessed January $26^{\text {th }} 2018$ ]
} 


\begin{tabular}{|l|l|l|}
\hline $\begin{array}{l}\text { Zoledronic } \\
\text { acid }\end{array}$ & IV & $\begin{array}{l}\text { By being a product administered intravenously, it is } \\
\text { unlikely to be prescribed in primary care. Less than } 24 \\
\text { items per month have been prescribed by GPs in } \\
\text { England since October } 2013 .^{3}\end{array}$ \\
\hline Teriparatide & $\begin{array}{l}\text { SC (self- } \\
\text { administration) }\end{array}$ & $\begin{array}{l}\text { Teriparatide was recommended by NICE TA161 for } \\
\text { postmenopausal women aged } 65 \text { years or older with } \\
\text { osteoporosis and a previous fragility fracture, who: } \\
\text { Are unable to take alendronate and risedronate, or have } \\
\text { a contraindication to or are intolerant to alendronate and } \\
\text { risedronate; } \\
\text { Or who have had an unsatisfactory response to } \\
\text { treatment with alendronate or risedronate. }\end{array}$ \\
$\begin{array}{l}\text { However, teriparatide was not included in the TA464 } \\
\text { final scope. }{ }^{2} \text { Furthermore, very few items have been } \\
\text { prescribed by GPs in England in the past few years (less } \\
\text { than 100 per month since the end of October 2013. }\end{array}$ \\
\hline $\begin{array}{l}\text { Sodium } \\
\text { clodronate }\end{array}$ & Oral and IV & $\begin{array}{l}\text { Bisphosphonate used for treating bone-related issues } \\
\text { arising as a consequence of diseases such as multiple } \\
\text { myeloma and breast cancer. }\end{array}$ \\
\hline
\end{tabular}

GP, general practitioner; IV, intravenous; NICE, National Institute for Health and Care Excellence; SC, subcutaneous; TA, technology appraisal.

4 National Institute for Health and Care Excellence. Raloxifene and teriparatide for the secondary prevention of osteoporotic fragility fractures in postmenopausal women. Technology appraisal guidance [TA161] 2008 [Available from: https://www.nice.org.uk/guidance/ta161, accessed 


\section{Appendix 3: Model formulas of mixed effects Poisson regression models.}

library(lme4)

\# Regression models with random effects for Clinical Commissioning Groups (CCGs) and all explanatory variables

\#

mod.CCG $<-$ glmer(ITEMS NUMBER_OF_PATIENTS_1000s + PERCENTAGE_FEMALES +

MEAN_AGE + PERCENTAGE_WHITE + as.factor(RURAL-URBAN_CATEGORY) + INCOME_DEPRIVATION_SCORE +

TIME +

(1|PRACTICE) + (1|CCG),

data $=$ data, family $=$ poisson)

\# Regression models with random effects for CCGs and income deprivation score as the only explanatory variable (plus time and number of patients for normalisation)

\#

mod.incomeOnly.CCG <- glmer(ITEMS NUMBER_OF_PATIENTS_1000s + INCOME_DEPRIVATION_SCORE +

TIME +

(1|PRACTICE) + (1|CCG),

data $=$ data, family $=$ poisson)

\# Regression models with all explanatory variables and without random effects for CCGs

\#

mod.noCCG <- glmer(ITEMS NUMBER_OF_PATIENTS_1000s + PERCENTAGE_FEMALES +

MEAN_AGE +

PERCENTAGE_WHITE + 


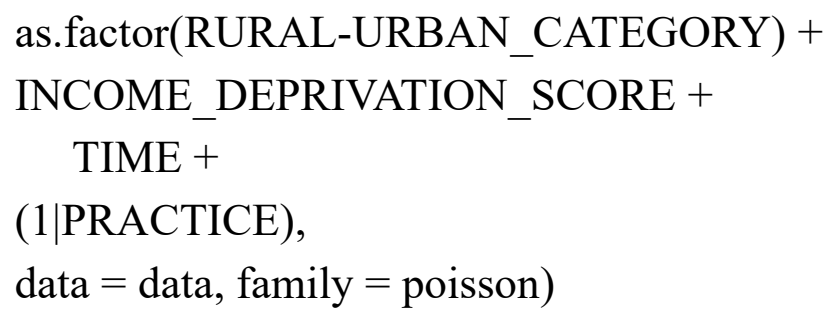

\# Regression models with income deprivation score as the only explanatory variable (plus time and number of patients for normalisation) and without random effects for CCGs

\#

mod.incomeOnly.noCCG $<$ - glmer(ITEMS $\sim$ NUMBER_OF_PATIENTS_1000s + INCOME_DEPRIVATION_SCORE +

TIME +

(1|PRACTICE),

data $=$ data, family $=$ poisson $)$ 
Appendix 4: Data available and included in the analyses.

Data available at GP practice level and data included in the analyses

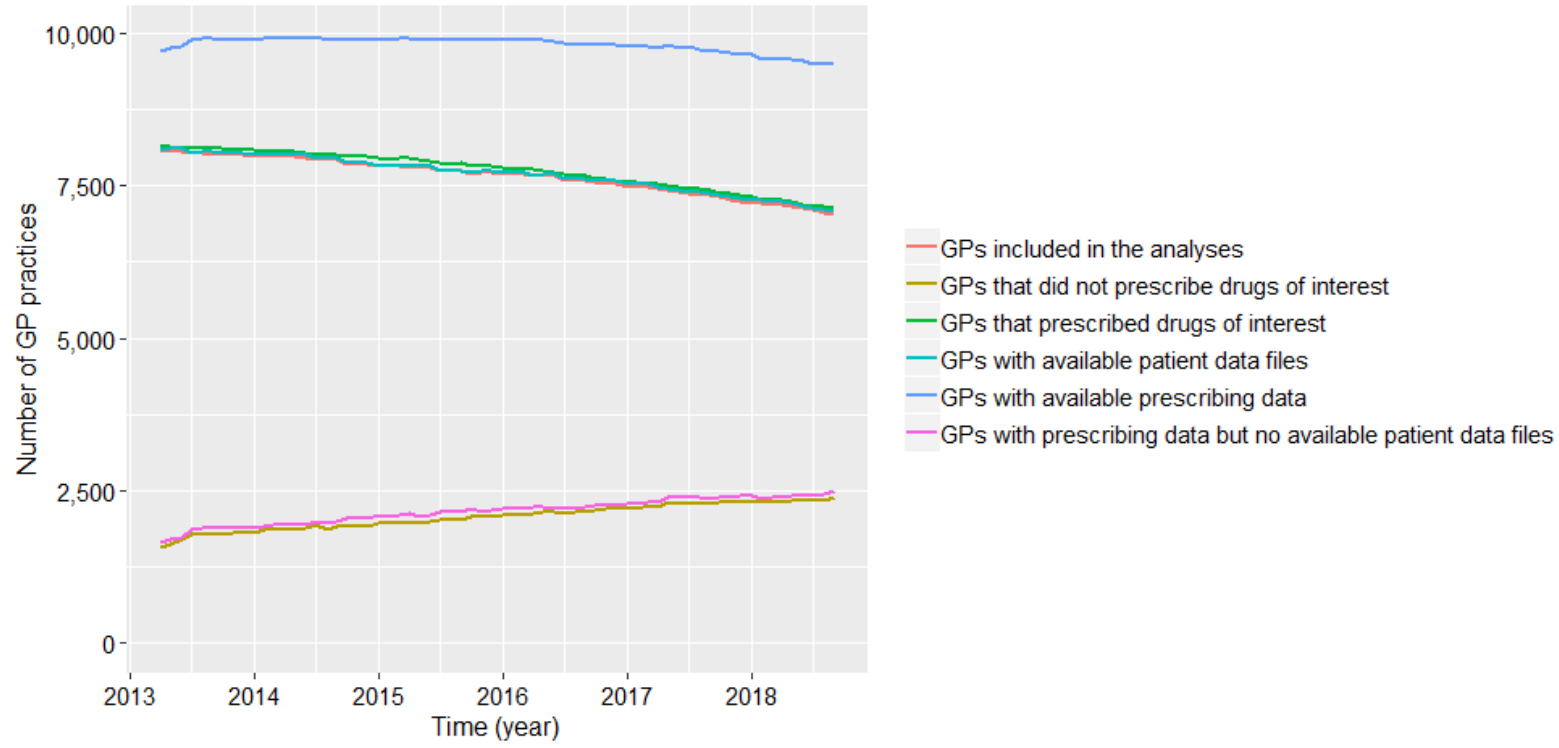

Summary of data available at GP practice level and data included in the analyses

\begin{tabular}{|c|c|c|c|c|c|c|}
\hline Year & $\begin{array}{c}\text { GPs with } \\
\text { available } \\
\text { prescribing } \\
\text { data }\end{array}$ & $\begin{array}{c}\text { GPs that } \\
\text { prescribed } \\
\text { drugs of } \\
\text { interest }\end{array}$ & $\begin{array}{c}\text { GPs that } \\
\text { did not } \\
\text { prescribe } \\
\text { drugs of } \\
\text { interest }\end{array}$ & $\begin{array}{c}\text { GPs with } \\
\text { available } \\
\text { patient } \\
\text { data files }\end{array}$ & $\begin{array}{c}\text { GPs with } \\
\text { prescribing } \\
\text { data but no } \\
\text { available } \\
\text { patient } \\
\text { data files }\end{array}$ & $\begin{array}{c}\text { GPs } \\
\text { included in } \\
\text { the } \\
\text { analyses }\end{array}$ \\
\hline $\mathbf{2 0 1 3}$ & 9856 & 8120 & 1736 & 8065 & 1819 & 8037 \\
\hline $\mathbf{2 0 1 4}$ & 9920 & 8034 & 1886 & 7963 & 1978 & 7942 \\
\hline $\mathbf{2 0 1 5}$ & 9906 & 7894 & 2012 & 7793 & 2129 & 7778 \\
\hline $\mathbf{2 0 1 6}$ & 9857 & 7705 & 2152 & 7650 & 2233 & 7624 \\
\hline $\mathbf{2 0 1 7}$ & 9747 & 7469 & 2278 & 7428 & 2360 & 7386 \\
\hline $\mathbf{2 0 1 8}$ & 9565 & 7231 & 2334 & 7196 & 2417 & 7148 \\
\hline
\end{tabular}

NOTE: The data above are averages for a given year. 


\section{Appendix 5: Total number of anti-osteoporosis prescriptions included in the final dataset for analysis and comparison with the data available at OpenPrescribing.net.}

These graphs include the prescriptions of strontium ranelate, which was excluded from the final analysis, demonstrating that its number of prescriptions declined rapidly in the last few years. The graphs demonstrate that different products are prescribed at different levels and therefore we implemented separate statistical models per product type (see the Methods section in the main document).




The table below reports the mean number of prescriptions (and standard deviation), per GP practice in England, of the anti-osteoporosis drugs included in our analyses between April 2013 and September 2018.

\begin{tabular}{|c|c|c|c|c|c|c|c|}
\hline Year & Month & $\begin{array}{l}\text { Alendronic } \\
\text { acid }\end{array}$ & $\begin{array}{l}\text { Alendronic } \\
\text { acid and } \\
\text { colecalciferol }\end{array}$ & Denosumab & $\begin{array}{l}\text { Ibandronic } \\
\text { acid }\end{array}$ & Raloxifene & $\begin{array}{l}\text { Risedronate } \\
\text { sodium }\end{array}$ \\
\hline 2013 & April & $75.1(61.4)$ & $0.2(0.7)$ & $0.1(0.4)$ & $2.4(3.9)$ & $0.9(1.7)$ & $7.4(8.7)$ \\
\hline 2013 & May & $78.1(64)$ & $0.2(0.8)$ & $0.1(0.4)$ & $2.5(4)$ & $0.9(1.7)$ & $7.7(9.1)$ \\
\hline 2013 & June & $72.2(59)$ & $0.2(0.7)$ & $0.1(0.4)$ & $2.3(3.7)$ & $0.9(1.7)$ & $7.1(8.4)$ \\
\hline 2013 & July & $79.1(64.2)$ & $0.2(0.8)$ & $0.1(0.4)$ & $2.4(3.9)$ & $0.9(1.7)$ & $7.8(9.2)$ \\
\hline 2013 & August & $77.8(63.6)$ & $0.2(0.8)$ & $0.1(0.4)$ & $2.4(3.8)$ & $0.9(1.7)$ & $7.7(9)$ \\
\hline 2013 & September & $74.5(60.4)$ & $0.2(0.8)$ & $0.1(0.4)$ & $2.3(3.7)$ & $0.8(1.6)$ & $7.4(8.7)$ \\
\hline 2013 & October & $79.6(64.3)$ & $0.2(0.7)$ & $0.1(0.5)$ & $2.4(3.9)$ & $0.9(1.8)$ & $7.9(9.2)$ \\
\hline 2013 & November & $76.3(62.1)$ & $0.2(0.7)$ & $0.1(0.5)$ & $2.3(3.8)$ & $0.9(1.7)$ & $7.5(8.8)$ \\
\hline 2013 & December & $78.9(64.3)$ & $0.2(0.8)$ & $0.1(0.4)$ & $2.3(3.8)$ & $0.9(1.7)$ & $7.8(9.2)$ \\
\hline 2014 & January & $78.4(63.7)$ & $0.2(0.8)$ & $0.1(0.5)$ & $2.3(3.8)$ & $0.9(1.7)$ & $7.8(9.2)$ \\
\hline 2014 & February & $71.1(57.5)$ & $0.2(0.7)$ & $0.1(0.5)$ & $2.1(3.5)$ & $0.8(1.6)$ & $7(8.3)$ \\
\hline 2014 & March & $75.7(61.4)$ & $0.2(0.7)$ & $0.1(0.5)$ & $2.2(3.7)$ & $0.8(1.6)$ & $7.7(9.2)$ \\
\hline 2014 & April & $76.2(61.9)$ & $0.2(0.7)$ & $0.1(0.5)$ & $2.2(3.7)$ & $0.8(1.7)$ & $7.7(9.2)$ \\
\hline 2014 & May & $78.8(64.4)$ & $0.2(0.8)$ & $0.2(0.6)$ & $2.3(3.8)$ & $0.8(1.7)$ & $7.9(9.3)$ \\
\hline 2014 & June & $75.1(61.1)$ & $0.2(0.8)$ & $0.2(0.6)$ & $2.2(3.6)$ & $0.8(1.6)$ & $7.5(8.9)$ \\
\hline 2014 & July & $80.8(65.5)$ & $0.2(0.8)$ & $0.2(0.6)$ & $2.3(3.9)$ & $0.9(1.7)$ & $8.1(9.6)$ \\
\hline 2014 & August & $75.6(61.7)$ & $0.2(0.7)$ & $0.2(0.6)$ & $2.1(3.6)$ & $0.8(1.6)$ & $7.5(9)$ \\
\hline 2014 & September & $77.7(62.8)$ & $0.2(0.7)$ & $0.2(0.7)$ & $2.2(3.7)$ & $0.8(1.6)$ & $7.8(9.3)$ \\
\hline 2014 & October & $81.9(66.1)$ & $0.2(0.8)$ & $0.2(0.7)$ & $2.3(3.8)$ & $0.8(1.7)$ & $8.1(9.8)$ \\
\hline 2014 & November & $73.6(59.3)$ & $0.2(0.7)$ & $0.2(0.7)$ & $2.1(3.5)$ & $0.8(1.6)$ & $7.3(8.8)$ \\
\hline 2014 & December & $82.4(66.3)$ & $0.2(0.8)$ & $0.2(0.7)$ & $2.3(3.8)$ & $0.9(1.7)$ & $8.2(9.9)$ \\
\hline 2015 & January & $76.6(61.1)$ & $0.2(0.7)$ & $0.2(0.7)$ & $2.1(3.6)$ & $0.8(1.6)$ & $7.7(9.3)$ \\
\hline
\end{tabular}




\begin{tabular}{|c|c|c|c|c|c|c|c|}
\hline 2015 & February & $70.5(56.3)$ & $0.1(0.6)$ & $0.2(0.7)$ & $2(3.3)$ & $0.7(1.5)$ & $7.1(8.6)$ \\
\hline 2015 & March & $77.7(62.3)$ & $0.2(0.7)$ & $0.3(0.9)$ & $2.2(3.7)$ & $0.8(1.6)$ & $7.7(9.4)$ \\
\hline 2015 & April & $75.8(60.6)$ & $0.2(0.7)$ & $0.3(0.8)$ & $2.1(3.6)$ & $0.8(1.6)$ & $7.6(9.1)$ \\
\hline 2015 & May & $74.1(59.7)$ & $0.1(0.6)$ & $0.3(0.8)$ & $2.1(3.5)$ & $0.8(1.5)$ & $7.4(8.9)$ \\
\hline 2015 & June & 77 (61.8) & $0.1(0.6)$ & $0.3(0.9)$ & $2.1(3.6)$ & $0.8(1.6)$ & $7.7(9.4)$ \\
\hline 2015 & July & $80.6(64.3)$ & $0.2(0.7)$ & $0.3(0.9)$ & $2.2(3.7)$ & $0.8(1.6)$ & $8.1(9.8)$ \\
\hline 2015 & August & $73.2(59)$ & $0.1(0.6)$ & $0.3(0.9)$ & $2(3.4)$ & $0.7(1.4)$ & $7.3(8.9)$ \\
\hline 2015 & September & $76.9(61.7)$ & $0.1(0.6)$ & $0.3(0.9)$ & $2.1(3.5)$ & $0.8(1.5)$ & $7.7(9.5)$ \\
\hline 2015 & October & $77.6(62.1)$ & $0.1(0.6)$ & $0.3(0.9)$ & $2.1(3.5)$ & $0.8(1.5)$ & $7.8(9.5)$ \\
\hline 2015 & November & $73.8(59.6)$ & $0.1(0.6)$ & $0.3(0.9)$ & $2(3.4)$ & $0.7(1.5)$ & $7.4(9.1)$ \\
\hline 2015 & December & $81.1(65.5)$ & $0.1(0.6)$ & $0.3(0.9)$ & $2.2(3.6)$ & $0.8(1.5)$ & $8.2(10.1)$ \\
\hline 2016 & January & $72.2(57.7)$ & $0.1(0.6)$ & $0.3(1)$ & $2(3.2)$ & $0.7(1.4)$ & $7.3(9)$ \\
\hline 2016 & February & $71.4(57.2)$ & $0.1(0.5)$ & $0.3(0.9)$ & $1.9(3.2)$ & $0.7(1.4)$ & $7.2(8.8)$ \\
\hline 2016 & March & $74.9(59.9)$ & $0.1(0.6)$ & $0.3(1)$ & $2(3.4)$ & $0.7(1.5)$ & $7.6(9.4)$ \\
\hline 2016 & April & $75.8(60.9)$ & $0.1(0.7)$ & $0.4(1.1)$ & $2(3.4)$ & $0.7(1.5)$ & $7.7(9.5)$ \\
\hline 2016 & May & $72.5(58.3)$ & $0.1(0.6)$ & $0.4(1)$ & $1.9(3.2)$ & $0.7(1.4)$ & $7.4(9.1)$ \\
\hline 2016 & June & $75.2(60.2)$ & $0.1(0.6)$ & $0.4(1.1)$ & $2(3.3)$ & $0.7(1.5)$ & $7.7(9.6)$ \\
\hline 2016 & July & $73.7(58.9)$ & $0.1(0.6)$ & $0.4(1)$ & $1.9(3.2)$ & $0.7(1.4)$ & $7.5(9.4)$ \\
\hline 2016 & August & $74.8(59.7)$ & $0.1(0.6)$ & 0.4 & $2(3.3)$ & $0.7(1.4)$ & $7.7(9.7)$ \\
\hline 2016 & September & $74.8(60.6)$ & $0.1(0.6)$ & $0.4(1.1)$ & $1.9(3.3)$ & $0.7(1.4)$ & $7.7(9.8)$ \\
\hline 2016 & October & $72.7(58.4)$ & $0.1(0.5)$ & $0.4(1.2)$ & $1.9(3.2)$ & $0.7(1.4)$ & $7.5(9.5)$ \\
\hline 2016 & November & $75(60.4)$ & $0.1(0.6)$ & $0.4(1.2)$ & $1.9(3.3)$ & $0.7(1.4)$ & $7.8(10.2)$ \\
\hline 2016 & December & $76(61.2)$ & $0.1(0.5)$ & $0.4(1.1)$ & $1.9(3.2)$ & $0.7(1.4)$ & $7.9(10)$ \\
\hline 2017 & January & $71.3(56.7)$ & $0.1(0.5)$ & $0.5(1.2)$ & $1.8(3)$ & $0.7(1.4)$ & $7.4(9.4)$ \\
\hline 2017 & February & $66.7(53.4)$ & $0.1(0.5)$ & $0.4(1.1)$ & $1.7(2.9)$ & $0.6(1.3)$ & $6.9(8.9)$ \\
\hline 2017 & March & $76.2(61.2)$ & $0.1(0.6)$ & $0.5(1.3)$ & $2(3.3)$ & $0.7(1.4)$ & $8(10.2)$ \\
\hline 2017 & April & $68(54.6)$ & $0.1(0.5)$ & $0.4(1.1)$ & $1.7(2.9)$ & $0.6(1.3)$ & $7.1(9.2)$ \\
\hline 2017 & May & $73.9(59.3)$ & $0.1(0.6)$ & $0.5(1.3)$ & $1.9(3.2)$ & $0.7(1.4)$ & $7.7(10.1)$ \\
\hline 2017 & June & $74.3(59.5)$ & $0.1(0.5)$ & $0.5(1.3)$ & $1.9(3.1)$ & $0.7(1.4)$ & $7.7(10.1)$ \\
\hline
\end{tabular}




\begin{tabular}{|c|c|c|c|c|c|c|c|}
\hline 2017 & July & $72(57.3)$ & $0.1(0.5)$ & $0.5(1.4)$ & $1.9(3.1)$ & $0.7(1.4)$ & $7.6(9.8)$ \\
\hline 2017 & August & $73.1(58.5)$ & $0.1(0.5)$ & $0.5(1.3)$ & $1.9(3.1)$ & $0.7(1.4)$ & $7.7(9.9)$ \\
\hline 2017 & September & $70.9(56.5)$ & $0.1(0.5)$ & $0.5(1.3)$ & $1.8(3)$ & $0.6(1.3)$ & $7.5(9.9)$ \\
\hline 2017 & October & $72.5(58)$ & $0.1(0.6)$ & $0.5(1.4)$ & $1.9(3.1)$ & $0.7(1.3)$ & $7.5(9.8)$ \\
\hline 2017 & November & $73.2(58.4)$ & $0.1(0.6)$ & $0.5(1.4)$ & $1.9(3.1)$ & $0.7(1.4)$ & $7.8(10.3)$ \\
\hline 2017 & December & $72.4(58.3)$ & $0.1(0.6)$ & $0.5(1.4)$ & $1.9(3.2)$ & $0.7(1.3)$ & $7.7(10.1)$ \\
\hline 2018 & January & $72.8(58)$ & $0.1(0.5)$ & $0.6(1.5)$ & $1.9(3.1)$ & $0.7(1.4)$ & $7.7(10.2)$ \\
\hline 2018 & February & $65.3(51.8)$ & $0.1(0.5)$ & $0.5(1.4)$ & $1.7(2.8)$ & $0.6(1.2)$ & $6.9(9.2)$ \\
\hline 2018 & March & $71.9(57.1)$ & $0.1(0.5)$ & $0.6(1.4)$ & $1.9(3.1)$ & $0.6(1.3)$ & $7.6(10.2)$ \\
\hline 2018 & April & $69.3(55.2)$ & $0.1(0.5)$ & $0.6(1.6)$ & $1.8(3)$ & $0.6(1.3)$ & $7.4(10)$ \\
\hline 2018 & May & $72.2(57.2)$ & $0.1(0.5)$ & $0.6(1.6)$ & $1.9(3.2)$ & $0.7(1.4)$ & $7.7(10.3)$ \\
\hline 2018 & June & $70.5(55.6)$ & $0.1(0.5)$ & $0.6(1.6)$ & $1.9(3.1)$ & $0.7(1.4)$ & $7.6(10.2)$ \\
\hline 2018 & July & $71.7(56.7)$ & $0.1(0.5)$ & $0.6(1.6)$ & $1.9(3.2)$ & $0.6(1.3)$ & $7.7(10.4)$ \\
\hline 2018 & August & $73.8(58.5)$ & $0.1(0.5)$ & $0.6(1.5)$ & $2(3.3)$ & $0.7(1.3)$ & $7.9(10.6)$ \\
\hline 2018 & September & $68.3(54.4)$ & $0.1(0.5)$ & $0.6(1.5)$ & $1.8(3)$ & $0.6(1.3)$ & $7.4(10.1)$ \\
\hline
\end{tabular}

The figure below displays the number of anti-osteoporosis prescriptions we downloaded from the internet and used in the current study compared with the data available at OpenPrescribing.net. The figure demonstrates we did not miss a substantial amount of data. The only notable difference between the data we used and the data available at OpenPrescribing.net can be observed for denosumab. This, however, is the result of excluding XGEVA ${ }^{\circledR}$ from our analyses, i.e. denosumab prescriptions indicated for the prevention of bone complications in adults with advanced cancer that has spread to the bone. 


\section{Comparison of prescription numbers used in analyses vs. numbers available at OpenPrescribing.net}

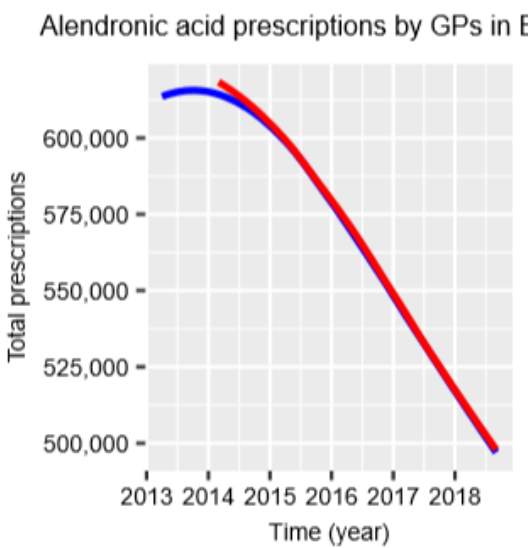

Denosumab prescriptions by GPs in England

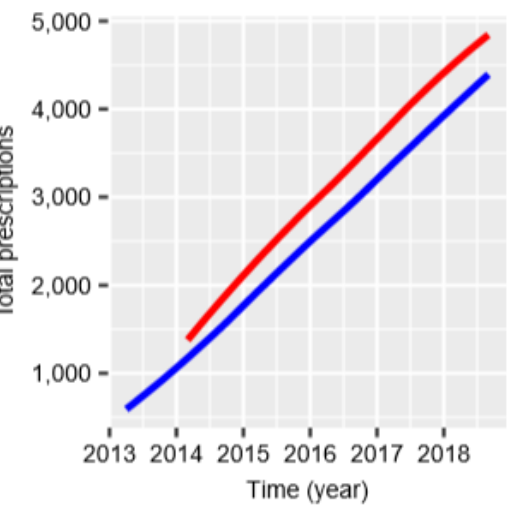

Raloxifene prescriptions by GPs in England

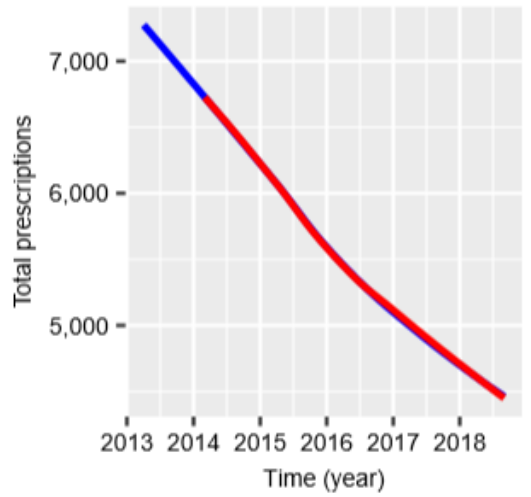

Alendronic acid and colecalciferol prescriptions by GPs in England

- Included in analysis OpenPrescribing net

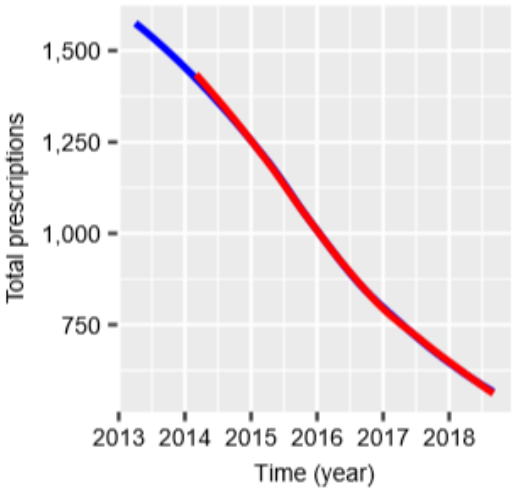

- Included in analysis - OpenPrescribing.net
- Included in analysis - OpenPrescribing.net

- Included in analysis - OpenPrescribing.net



- Included in analysis - OpenPrescribing.net
$55,000-$

$20^{\prime} 1320142015201620^{\prime} 172018$ Time (year)

Risedronate sodium prescriptions by GPs in England

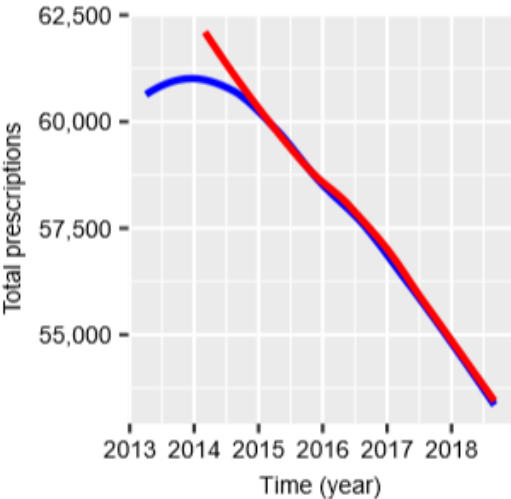

- Included in analysis - OpenPrescribing.net 


\section{Appendix 6: Additional exploratory analyses.}

We visually analysed the frequency of the number of prescriptions, at each time point, for all products together and for each product separately with histograms. We assessed the distributions of the proportion of females and mean age across GP practices, at each time point, using histograms. We plotted a histogram to understand the proportion of white people per LSOA as per the 2011 Census. We constructed scatter plots and box plots to visually evaluate any potential relationships between prescription rates and quantitative and qualitative variables, respectively, included in Table 3.2 of the main document. We used box plots to visually judge whether consistently different prescription levels, for each product, may exist in different CCGs. Below we present examples of outputs from our exploratory analyses, using alendronic acid and denosumab prescription data.

Total prescriptions of alendronic acid by GPs in England in September 2018

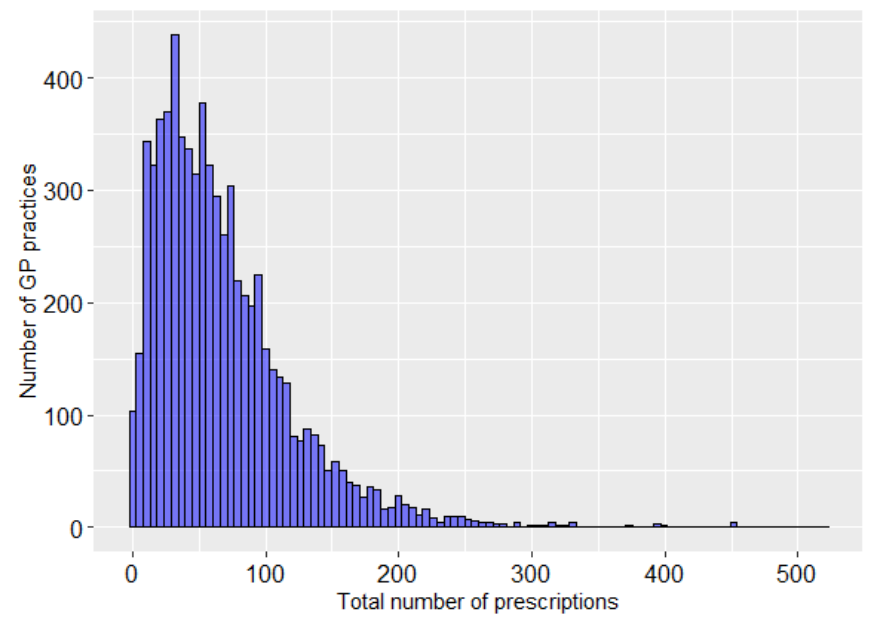

\section{Distribution of mean age across GP practices in England in September 2018}

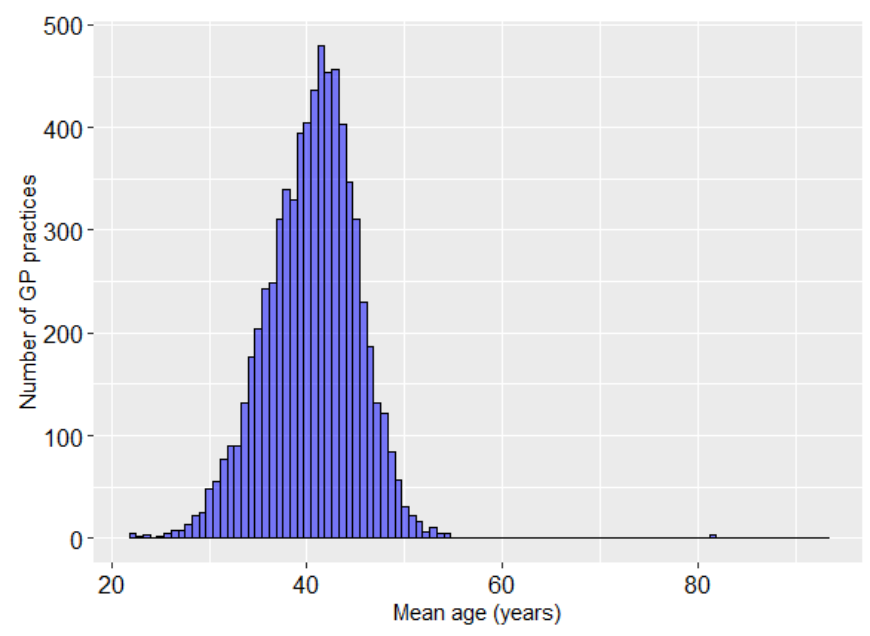


Distribution of the proportion of females across GP practices in England in September 2018

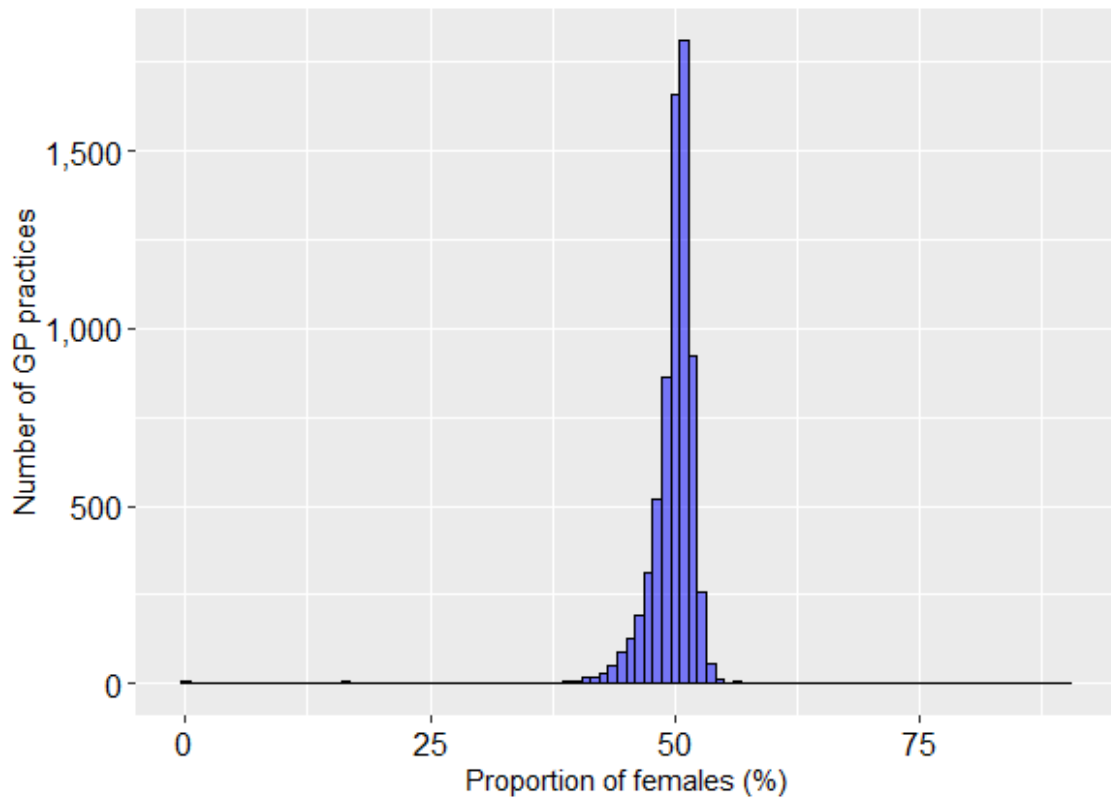

Total prescriptions of alendronic acid by GPs in England vs mean age of patients in September 2018

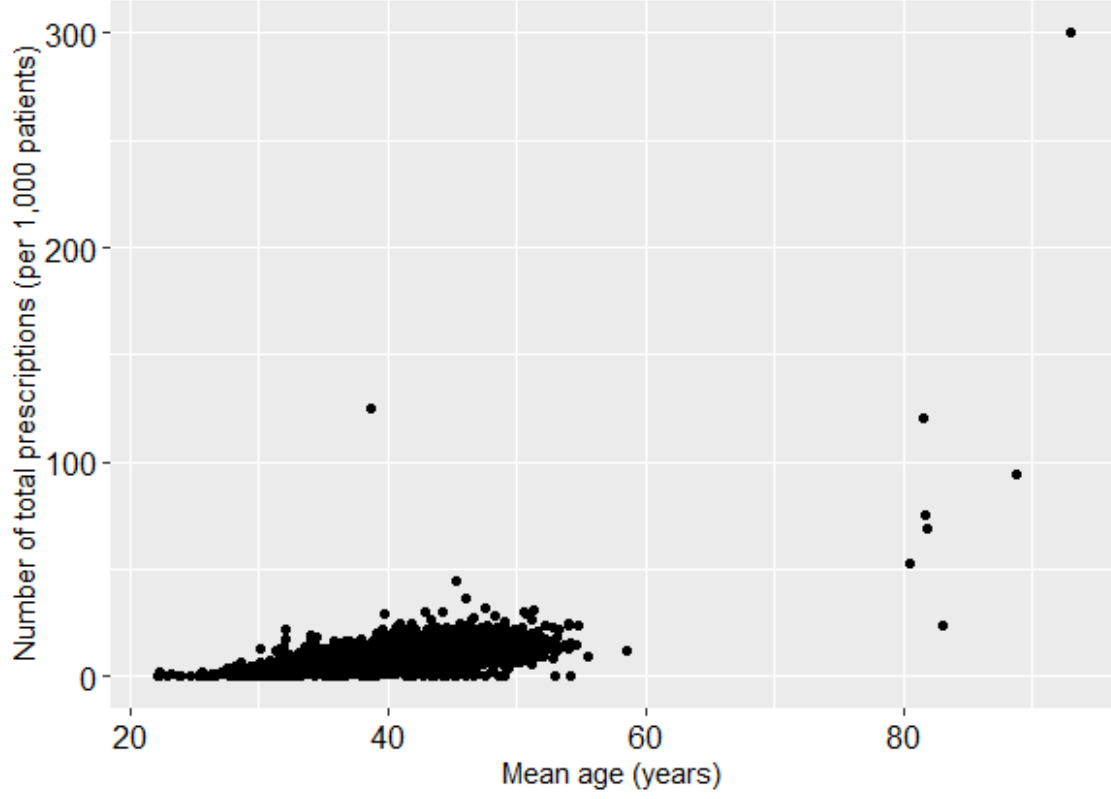


Total prescriptions of alendronic acid by GPs in England vs proportion of females in September 2018

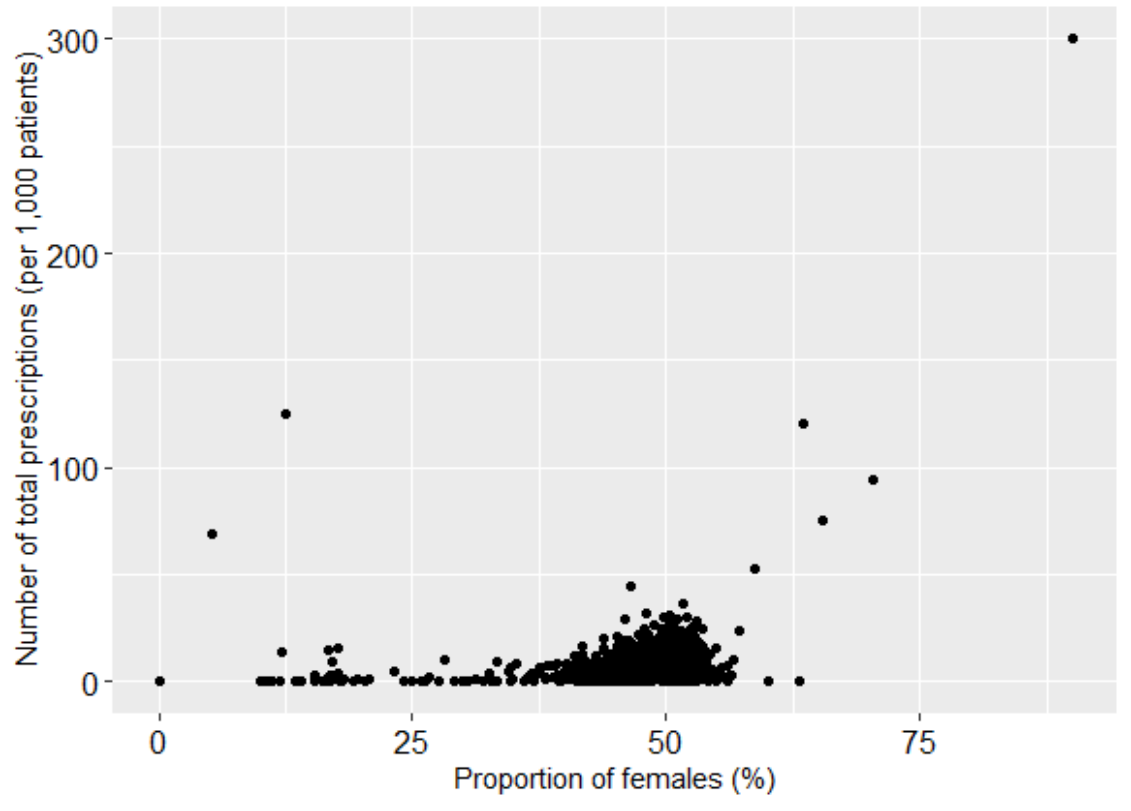

Total prescriptions of alendronic acid by GPs in England in September 2018 vs proportion of white people (seven practices with prescription levels higher than 50 items per 1,000 not shown for clarity purposes)

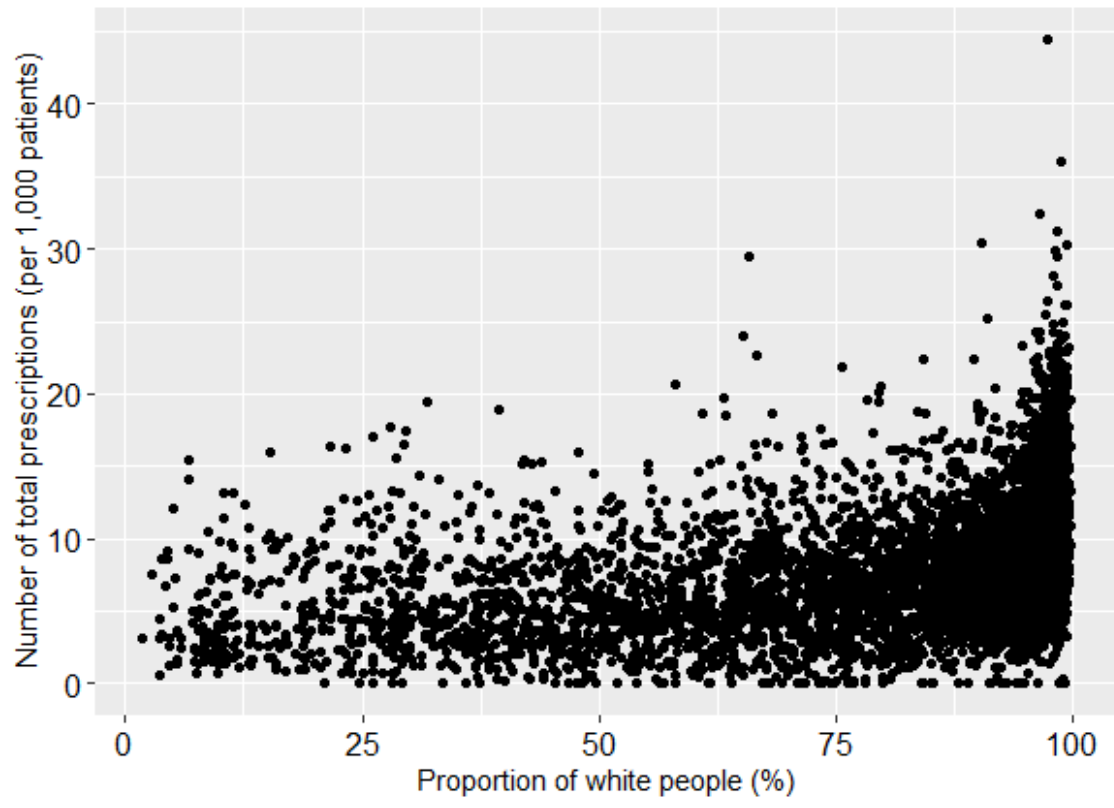


Total prescriptions of alendronic acid by GPs in England in September 2018 by rural category

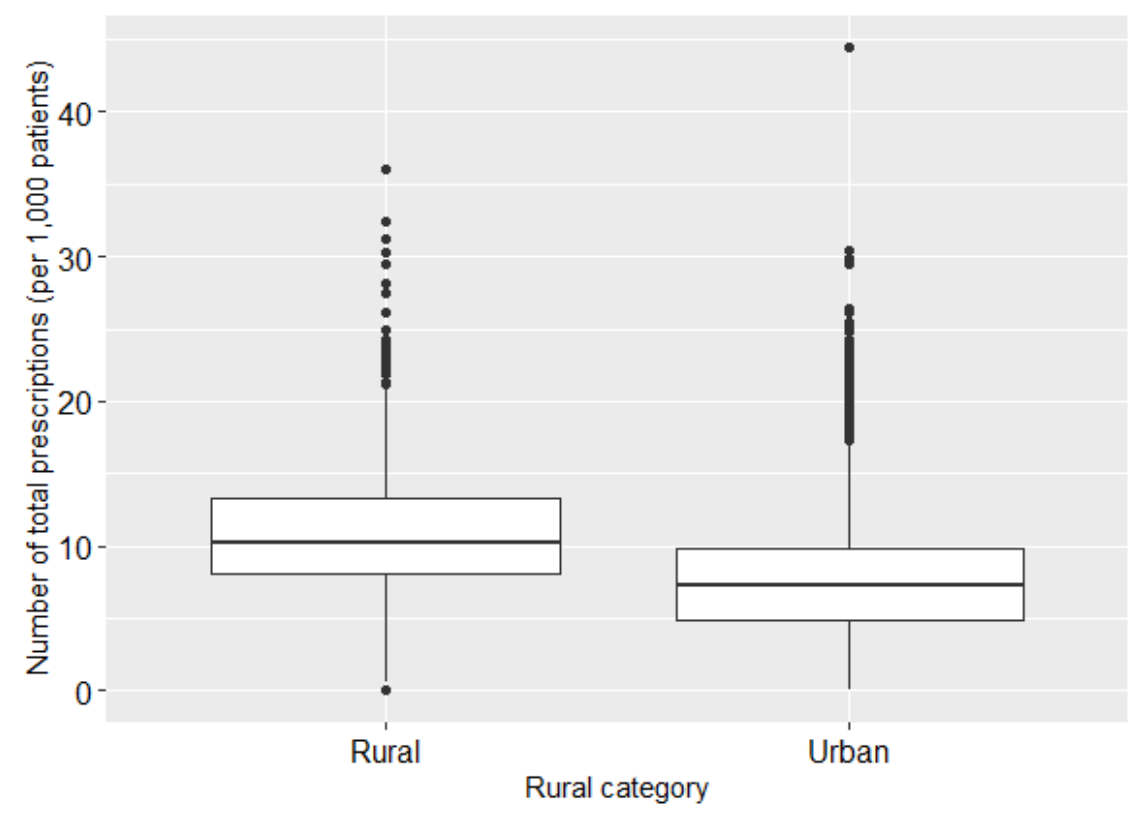

Total prescriptions of alendronic acid by GPs in England in September 2018 vs Index of Multiple Deprivation rank (seven practices with prescription levels higher than 50 items per 1,000 not shown for clarity purposes)

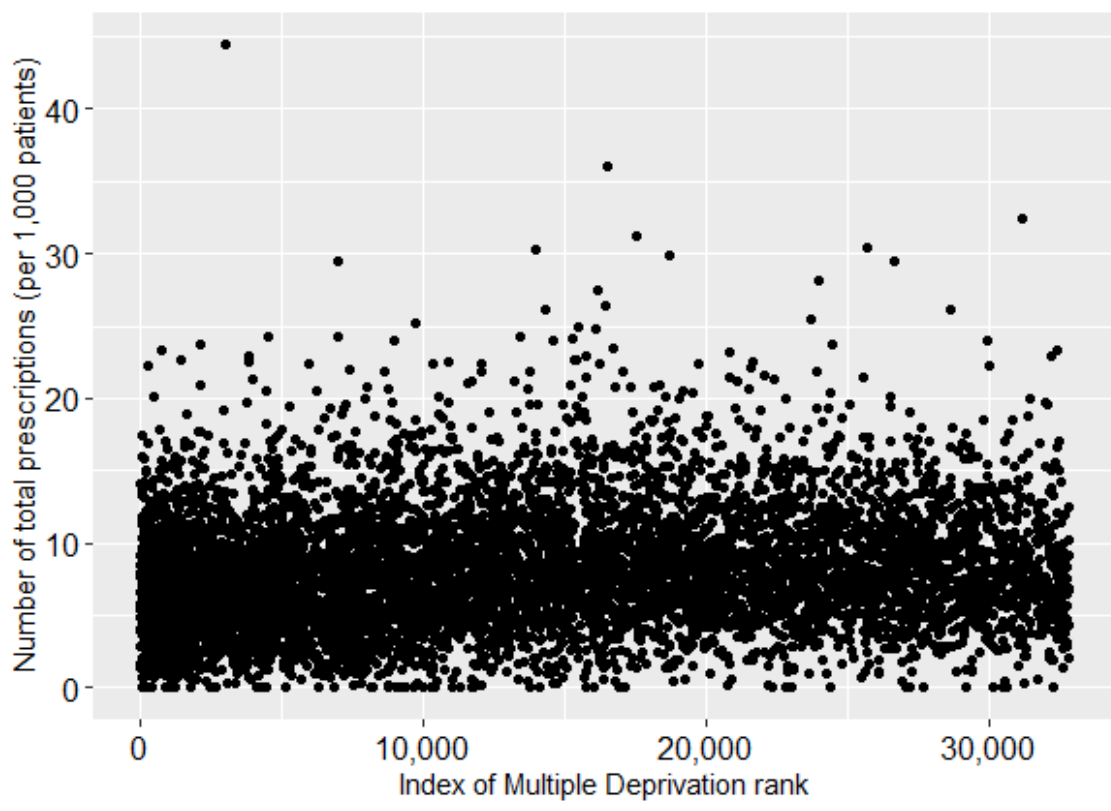


Total prescriptions of alendronic acid by GPs in England in September 2018 by Index of Multiple Deprivation decile

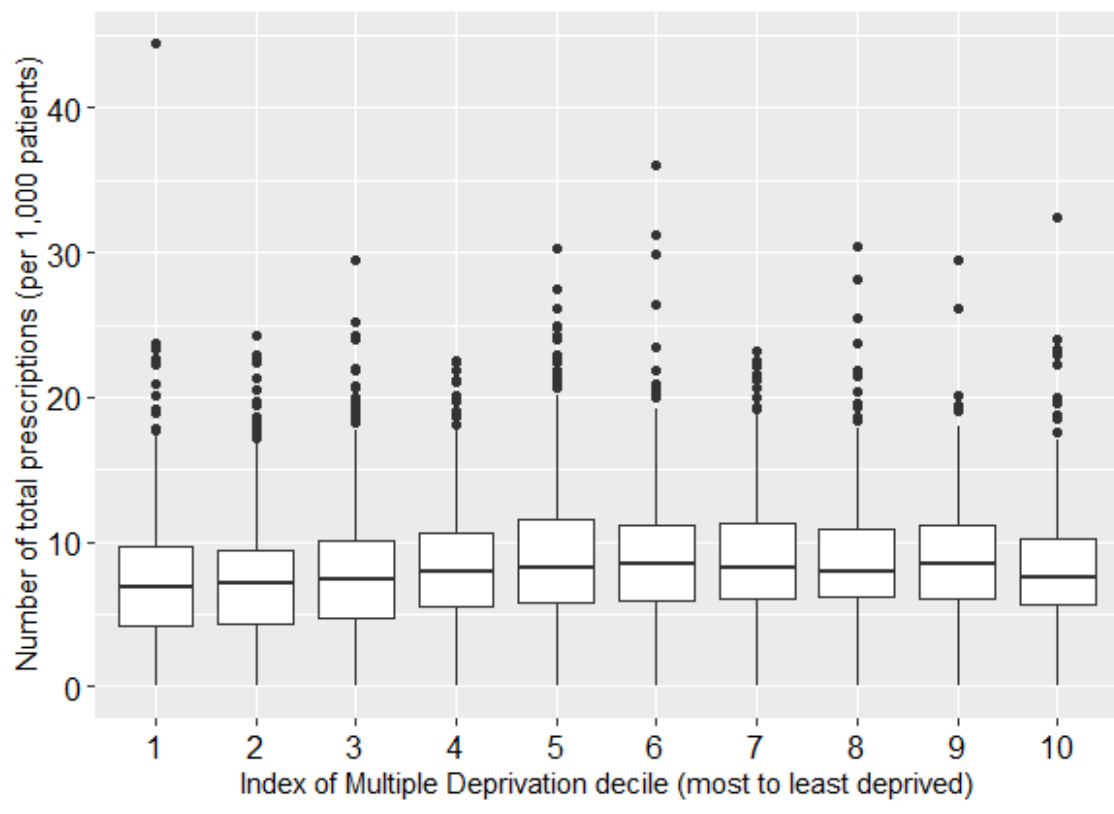

Total prescriptions of denosumab by GPs in England in September 2018 by Index of Multiple Deprivation decile

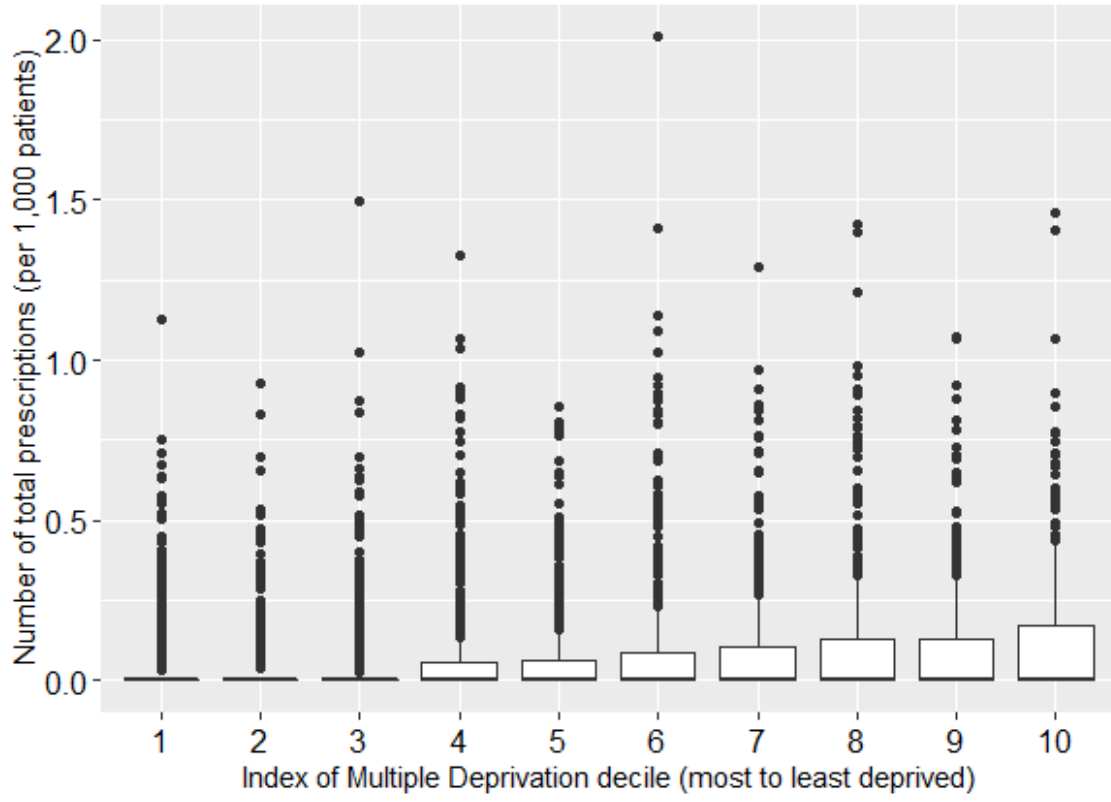




\section{Total prescriptions of alendronic acid by GPs in England in September 2018, grouped by CCG}

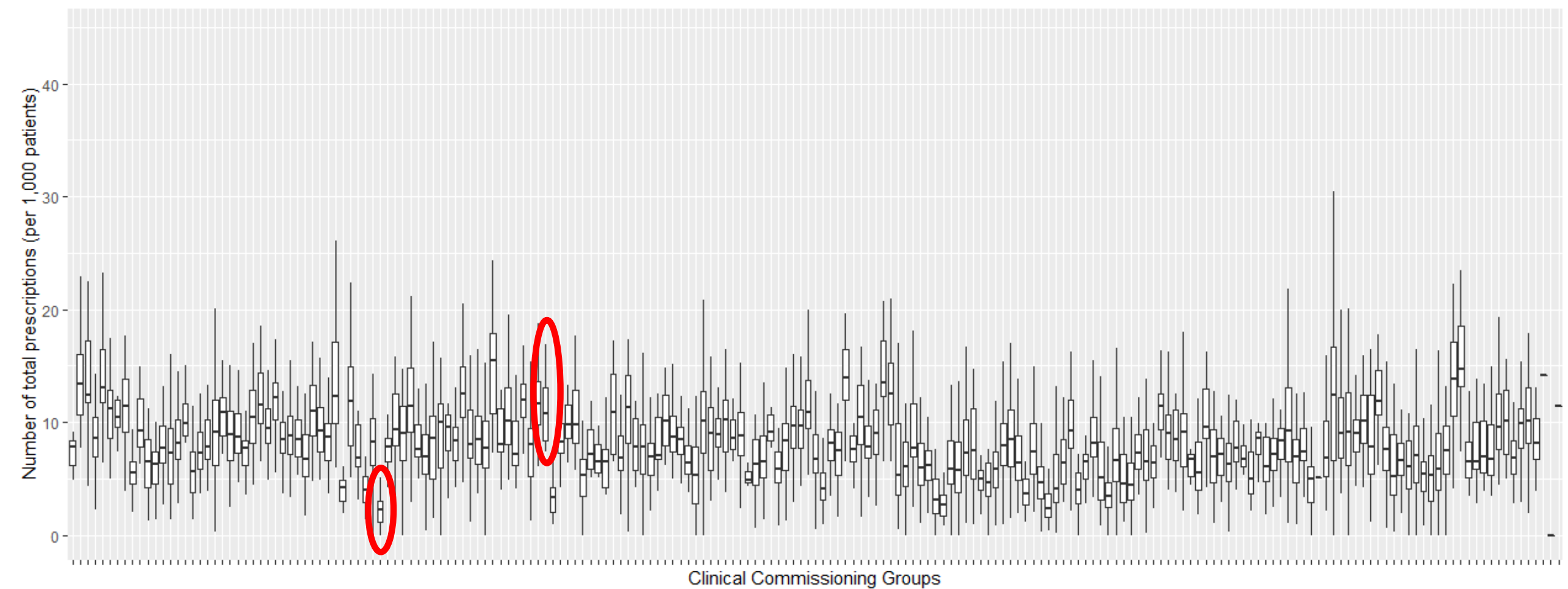

This graph depicts the variability of alendronic acid prescriptions across CCGs. The two CCGs encircled (in red) in this figure illustrate that GPs belonging to different CCGs may prescribe certain drugs at different rates. 
Appendix 7: Mixed-effects regression model results: estimates (and 95\% confidence intervals) of models without random effects for CCGs, with and without demographic and rural-urban characteristics.

\begin{tabular}{|c|c|c|c|c|c|c|c|c|c|c|c|c|}
\hline & \multicolumn{2}{|c|}{ Alendronic acid } & \multicolumn{2}{|c|}{$\begin{array}{l}\text { Alendronic acid } \\
\text { and colecalciferol }\end{array}$} & \multicolumn{2}{|c|}{ Denosumab } & \multicolumn{2}{|c|}{ Ibandronic acid } & \multicolumn{2}{|c|}{ Raloxifene } & \multicolumn{2}{|c|}{$\begin{array}{l}\text { Risedronate } \\
\text { sodium }\end{array}$} \\
\hline & $\begin{array}{c}\text { Full } \\
\text { model }\end{array}$ & $\begin{array}{c}\text { Reduced } \\
\text { model }\end{array}$ & $\begin{array}{c}\text { Full } \\
\text { model }\end{array}$ & $\begin{array}{c}\text { Reduced } \\
\text { model }\end{array}$ & $\begin{array}{c}\text { Full } \\
\text { model }\end{array}$ & $\begin{array}{c}\text { Reduced } \\
\text { model }\end{array}$ & $\begin{array}{l}\text { Full } \\
\text { model }\end{array}$ & $\begin{array}{c}\text { Reduced } \\
\text { model }\end{array}$ & $\begin{array}{l}\text { Full } \\
\text { model }\end{array}$ & $\begin{array}{c}\text { Reduced } \\
\text { model }\end{array}$ & $\begin{array}{c}\text { Full } \\
\text { model }\end{array}$ & $\begin{array}{l}\text { Reduced } \\
\text { model }\end{array}$ \\
\hline Intercept & $\begin{array}{c}108.306 \\
(107.957 \text { to } \\
108.654)^{* * *}\end{array}$ & $\begin{array}{c}89.028 \\
(88.643 \text { to } \\
89.412)^{* * *}\end{array}$ & $\begin{array}{c}410.992 \\
(409.363 \text { to } \\
412.622)^{* * *}\end{array}$ & $\begin{array}{c}391.508 \\
(389.267 \text { to } \\
393.749)^{* * *}\end{array}$ & $\begin{array}{c}-565.865 \\
(-567.323 \text { to } \\
-564.406)^{* * *}\end{array}$ & $\begin{array}{c}-606.908 \\
(-613.837 \text { to } \\
-599.979)^{* * *}\end{array}$ & $\begin{array}{c}185.159 \\
(184.431 \text { to } \\
185.888)^{* * *}\end{array}$ & $\begin{array}{c}160.702 \\
(159.624 \text { to } \\
161.779)^{* * *}\end{array}$ & $\begin{array}{l}200.967 \\
(199.119 \text { to } \\
202.814)^{* * *}\end{array}$ & $\begin{array}{c}186.503 \\
(186.307 \text { to } \\
186.699)^{* * *}\end{array}$ & $\begin{array}{c}68.211 \\
(67.683 \text { to } \\
68.739)^{* * *}\end{array}$ & $\begin{array}{c}54.326 \\
(53.294 \text { to } \\
55.357)^{* * *}\end{array}$ \\
\hline $\begin{array}{l}\text { Patients } \\
(1,000 \mathrm{~s})\end{array}$ & $\begin{array}{c}0.049 \\
(0.049 \text { to } \\
0.049)^{* * *}\end{array}$ & $\begin{array}{l}0.046(0.046 \\
\text { to } 0.047)^{* * *}\end{array}$ & $\begin{array}{c}0.067 \\
(0.061 \text { to } \\
0.074)^{* * *}\end{array}$ & $\begin{array}{c}0.067 \\
(0.060 \text { to } \\
0.073)^{* * *}\end{array}$ & $\begin{array}{c}0.065 \\
(0.062 \text { to } \\
0.068)^{* * *}\end{array}$ & $\begin{array}{c}0.057 \\
(0.054 \text { to } \\
0.061)^{* * *}\end{array}$ & $\begin{array}{c}0.062 \\
(0.060 \text { to } \\
0.063)^{* * *}\end{array}$ & $\begin{array}{c}0.058 \\
(0.057 \text { to } \\
0.060)^{* * *}\end{array}$ & $\begin{array}{c}0.053 \\
(0.050 \text { to } \\
0.055)^{* * *}\end{array}$ & $\begin{array}{c}0.050 \\
(0.048 \text { to } \\
0.053)^{* * *}\end{array}$ & $\begin{array}{c}0.051 \\
(0.051 \text { to } \\
0.052)^{* * *}\end{array}$ & $\begin{array}{c}0.049 \\
(0.048 \text { to } \\
0.050)^{* * *}\end{array}$ \\
\hline $\begin{array}{l}\text { Sex }(\% \\
\text { females })\end{array}$ & $\begin{array}{c}0.037 \\
(0.036 \text { to } \\
0.038)^{* * *}\end{array}$ & & $\begin{array}{c}0.015 \\
(0.003 \text { to } \\
0.026)^{*}\end{array}$ & & $\begin{array}{c}0.094 \\
(0.083 \text { to } \\
0.105)^{* * *}\end{array}$ & & $\begin{array}{c}0.056 \\
(0.051 \text { to } \\
0.061)^{* * *}\end{array}$ & & $\begin{array}{c}0.071 \\
(0.063 \text { to } \\
0.078)^{* * *}\end{array}$ & & $\begin{array}{c}0.052 \\
(0.050 \text { to } \\
0.054)^{* * *}\end{array}$ & \\
\hline $\begin{array}{l}\text { Age (mean } \\
\text { years) }\end{array}$ & $\begin{array}{c}0.051 \\
(0.050 \text { to } \\
0.051)^{* * *}\end{array}$ & & $\begin{array}{c}0.040 \\
(0.029 \text { to } \\
0.051)^{* * *}\end{array}$ & & $\begin{array}{c}0.124 \\
(0.116 \text { to } \\
0.132)^{* * *}\end{array}$ & & $\begin{array}{c}0.061 \\
(0.058 \text { to } \\
0.065)^{* * *}\end{array}$ & & $\begin{array}{c}0.050 \\
(0.044 \text { to } \\
0.056)^{* * *}\end{array}$ & & $\begin{array}{c}0.042 \\
(0.041 \text { to } \\
0.044)^{* * *}\end{array}$ & \\
\hline $\begin{array}{l}\text { Rural-urban } \\
\text { category } \\
\text { (rural=0) }\end{array}$ & $\begin{array}{c}-0.020 \\
(-0.032 \text { to } \\
-0.008)^{* *}\end{array}$ & & $\begin{array}{c}0.550 \\
(0.290 \text { to } \\
0.811)^{* * *}\end{array}$ & & $\begin{array}{c}0.092 \\
(-0.031 \text { to } \\
0.215)\end{array}$ & & $\begin{array}{c}-0.020 \\
(-0.074 \text { to } \\
0.034)\end{array}$ & & $\begin{array}{c}-0.236 \\
(-0.333 \text { to } \\
-0.138)^{* * *}\end{array}$ & & $\begin{array}{c}-0.130 \\
(-0.170 \text { to } \\
-0.091)^{* * *}\end{array}$ & \\
\hline $\begin{array}{l}\text { Ethnicity } \\
\text { (\% white) }\end{array}$ & $\begin{array}{c}0 \\
(-0.001 \text { to } \\
0)^{* *}\end{array}$ & & $\begin{array}{c}-0.006 \\
(-0.011 \text { to } \\
-0.002)^{* *}\end{array}$ & & $\begin{array}{c}0.023 \\
(0.021 \text { to } \\
0.026)^{* * *}\end{array}$ & & $\begin{array}{c}0.013 \\
(0.011 \text { to } \\
0.015)^{* * *}\end{array}$ & & $\begin{array}{c}0.025 \\
(0.022 \text { to } \\
0.028)^{* * *}\end{array}$ & & $\begin{array}{c}0.003 \\
(0.003 \text { to } \\
0.004)^{* * *}\end{array}$ & \\
\hline $\begin{array}{l}\text { Income } \\
\text { score }(\% \\
\text { deprived })\end{array}$ & $\begin{array}{c}-0.001 \\
(-0.002 \text { to } \\
-0.001)^{* * *}\end{array}$ & $\begin{array}{c}-0.002 \\
(-0.003 \text { to } \\
-0.002)^{* * *}\end{array}$ & $\begin{array}{c}-0.013 \\
(-0.020 \text { to } \\
-0.006)^{* * *}\end{array}$ & $\begin{array}{c}0.007 \\
\text { ( } 0 \text { to } 0.014 \text { ) }\end{array}$ & $\begin{array}{c}-0.017 \\
(-0.021 \text { to } \\
-0.013)^{* * *}\end{array}$ & $\begin{array}{c}-0.036 \\
(-0.040 \text { to } \\
-0.032)^{* * *}\end{array}$ & $\begin{array}{c}-0.008 \\
(-0.010 \text { to } \\
-0.007)^{* * *}\end{array}$ & $\begin{array}{c}-0.014 \\
(-0.016 \text { to } \\
-0.012)^{* * *}\end{array}$ & $\begin{array}{c}-0.002 \\
(-0.005 \text { to } \\
0.002)\end{array}$ & $\begin{array}{c}-0.011 \\
(-0.014 \text { to } \\
-0.008)^{* * * *}\end{array}$ & $\begin{array}{c}-0.001 \\
(-0.002 \text { to } \\
0)^{* *}\end{array}$ & $\begin{array}{c}-0.004 \\
(-0.005 \text { to } \\
-0.003)^{* * *}\end{array}$ \\
\hline
\end{tabular}




\begin{tabular}{|c|c|c|c|c|c|c|c|c|c|c|c|c|}
\hline $\begin{array}{l}\text { Time (year } \\
\text { and month) } \\
\text { a }\end{array}$ & $\begin{array}{c}-0.054 \\
(-0.054 \text { to } \\
-0.054)^{* * *}\end{array}$ & $\begin{array}{c}-0.042 \\
(-0.043 \text { to } \\
-0.042)^{* * *}\end{array}$ & $\begin{array}{c}-0.209 \\
(-0.210 \text { to } \\
-0.208)^{* * *}\end{array}$ & $\begin{array}{c}-0.199 \\
(-0.200 \text { to } \\
-0.198)^{* * *}\end{array}$ & $\begin{array}{c}0.273 \\
(0.272 \text { to } \\
0.274)^{* * *}\end{array}$ & $\begin{array}{c}0.299 \\
(0.296 \text { to } \\
0.303)^{* * *}\end{array}$ & $\begin{array}{c}-0.095 \\
(-0.096 \text { to } \\
-0.095)^{* * *}\end{array}$ & $\begin{array}{c}-0.08 \\
(-0.081 \text { to } \\
-0.080)^{* * *}\end{array}$ & $\begin{array}{c}-0.105 \\
(-0.106 \text { to } \\
-0.104)^{* * *}\end{array}$ & $\begin{array}{c}-0.094 \\
(-0.094 \text { to } \\
-0.094)^{* * *}\end{array}$ & $\begin{array}{c}-0.036 \\
(-0.036 \text { to } \\
-0.035)^{* * *}\end{array}$ & $\begin{array}{c}-0.026 \\
(-0.027 \text { to } \\
-0.026)^{* * *}\end{array}$ \\
\hline AIC & $4,293,553$ & $4,322,841$ & 206,592 & 206,574 & 453,391 & 455,282 & $1,272,909$ & $1,274,744$ & 740,538 & 741,707 & $2,299,736$ & $2,304,076$ \\
\hline $\mathrm{BIC}$ & $4,293,653$ & $4,322,896$ & 206,692 & 206,629 & 453,491 & 455,338 & $1,273,010$ & $1,274,799$ & 740,638 & 741,763 & $2,299,836$ & $2,304,132$ \\
\hline Marginal $\mathrm{R}^{2}$ & 0.225 & 0.061 & 0.011 & 0.006 & 0.231 & 0.065 & 0.144 & 0.028 & 0.107 & 0.011 & 0.129 & 0.030 \\
\hline $\begin{array}{l}\text { Conditional } \\
\mathrm{R}^{2}\end{array}$ & 0.983 & 0.986 & 1 & 1 & 0.815 & 0.806 & 0.950 & 0.955 & 0.982 & 0.982 & 0.940 & 0.947 \\
\hline $\mathrm{N}^{\mathrm{b}}$ & \multicolumn{2}{|c|}{505,407} & \multicolumn{2}{|c|}{505,407} & \multicolumn{2}{|c|}{505,407} & \multicolumn{2}{|c|}{505,407} & \multicolumn{2}{|c|}{505,407} & \multicolumn{2}{|c|}{505,407} \\
\hline
\end{tabular}

Significance codes: $* * *$ for $\mathrm{p}<0.001 ; * *$ for $\mathrm{p}<0.01 ; *$ for $\mathrm{p}<0.05$.

AIC, Akaike information criterion; BIC, Bayesian information criterion; CCGs, Clinical Commissioning Groups; GP, general practitioner.

${ }^{a}$ The variable time took 66 different values, from prescriptions in April 2013 where time was 2013.25 to September 2018 where time was 2018.67.

${ }^{\mathrm{b}}$ Total number of prescription entries captured in the final dataset, which includes one entry per GP practice per time point.

NOTE: Cells in the table above were greyed out if confidence intervals contained zeros. 
Publication details: Bone. 2020 Jan;130:115125. doi: 10.1016/j.bone.2019.115125. Epub 2019 Nov 2

Impact factor: $4.36(2018)$

Authors: Ion Agirrezabal (0000-0003-3170-7845) , Juan M Cabasés (0000-0003-0207-4137) Gian Luca Di Tanna (0000-0002-5470-3567) ${ }^{\mathrm{b}}$, Eduardo Sánchez-Iriso (0000-0002-5320-8732) ${ }^{\mathrm{a}}$

\section{Affiliations:}

${ }^{\text {a}}$ Department of Economics, Public University of Navarre, 31006 Pamplona/Iruña, Spain

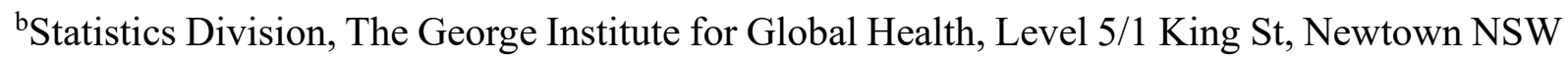
2042, Australia

Correspondence to: Ion Agirrezabal; Email: ion.agirrezabal@unavarra.es; Phone: 0034948166205

Other email addresses: Juan M Cabasés: jmcabases@unavarra.es; Gian Luca Di Tanna: glditanna@gmail.com; Eduardo Sánchez-Iriso: eduardo.sanchez@unavarra.es

Declaration of interest: All authors have completed the ICMJE conflict of interest form and declare: no support from any organisation for the submitted work; IA and GLDT were Amgen employees during a period prior to the manuscript submission date; ESI and JMC declare no financial relationships with any organisations that might have an interest in the submitted work; no other relationships or activities that could appear to have influenced the submitted work.

Funding: None.

Note: Table and figure numbers are not shown as published. These have been updated to show the chapter number in this thesis.

Information not provided on the published paper: Key R code scripts used in these analyses is provided in Addendum 1. 
upna 
Chapter 4

Real-world budget impact of the adoption of insulin glargine biosimilars in primary care in England (2015-2018)

Diabetes Care. 2020 Jun 11;dc192395. doi: 10.2337/dc19-2395. Online ahead of print. 


\begin{abstract}
Background: Lantus ${ }^{\circledR}$, the reference insulin glargine used for the treatment of diabetes, lost its patent protection in 2014 opening the market to biosimilar competitors.

Objective: First, to analyse the adoption rates of insulin glargine biosimilars in primary care in England and estimate the savings realised, and missed, since an insulin glargine biosimilar was first used. Second, to assess potential variations in adoption rates across Clinical Commissioning Groups (CCGs).
\end{abstract}

Methods: Datasets capturing information on all insulin glargine items prescribed by all general practitioners (GPs) up to December 2018 were used. Total costs of insulin glargine and uptake rates of biosimilars were calculated. The real-world budget impact was estimated assuming the cost of reference insulin glargine for all items and comparing the total costs in this scenario with the total costs in the real world. The missed savings were estimated assuming the cost of biosimilars for all insulin glargine items. Choropleth maps were generated to assess potential variations in uptake across CCGs.

Results: Insulin glargine biosimilars generated savings of $£ 900 \mathrm{~K}$ between October 2015 (time of first prescription) and December 2018. The missed savings amounted to $£ 25.6 \mathrm{M}$ in this period, indicating that only $3.42 \%$ of the potential savings were achieved. The analyses demonstrated a large level of variation in the uptake of insulin glargine biosimilars across CCGs, with market shares ranging from $0 \%$ to $53.3 \%$ (December 2018).

Conclusions: These results may encourage decision-makers in England to promote the use of best value treatments in primary care and to re-evaluate variation across CCGs.

\title{
KEYWORDS
}

Diabetes; Insulin glargine; Biosimilars; Prescriptions; Budget impact; England.

\section{KEY ABBREVIATIONS}

ABCD, Association of British Clinical Diabetologists; CCG, Clinical Commissioning Group; EMA, European Medicines Agency; FOI, Freedom of Information; GP, general practitioner; NHS, National Health Service; LTP, Long-term plan; RMOC, Regional Medicines Optimisation Committee. 


\section{INTRODUCTION}

Biosimilars, as defined by the European Medicines Agency (EMA), are medicines considered to be highly similar to another medicine already marketed in the European Union (EU), i.e. the reference product. Due to the natural variability associated with the production of biological medicines, the EMA acknowledge that minor differences can exist between the biosimilar and its reference product, but these are not meaningful in terms of quality, safety and efficacy according to the EMA (1). Prices of biosimilars are typically lower than those of the corresponding reference products, and NHS England estimated that potential savings with biosimilar adoption could reach $£ 300 \mathrm{~m}$ per year by 2021, i.e. equal to $1.8 \%$ of the total expenditure on medicines in $2015 / 16$ (2). For this reason, in 2017 NHS England put in place a Commissioning Framework to optimise the use of biological medicines and promote the use of biosimilars when clinically appropriate (2). This framework emphasised the potential for improvement in specialised services, focusing on savings that could be realised from a wide adoption of adalimumab, etanercept, infliximab, rituximab and trastuzumab biosimilars (2). Despite its focus on secondary-care medicines, the potential savings from the adoption of biosimilars in primary care, such as those resulting from the uptake of insulin glargine biosimilars, should not be underestimated.

The patent on the Lantus ${ }^{\circledR}$, the reference insulin glargine for the treatment of diabetes mellitus in adults, adolescents and children aged two years and above, expired in 2014 in Europe and the United States (3; 4). Since then, several companies have launched insulin glargine biosimilars, including Abasaglar $\AA$ (approved by the EMA in September 2014) and Semglee ${ }^{\circledR}$ (approved by the EMA in January 2018) (3). Following the approval of Abasaglar ${ }^{\circledR}$, the Association of British Clinician Diabetologists (ABCD) released a statement acknowledging the potential savings that insulin glargine biosimilars could bring to the National Health Service (NHS) without compromising patients' safety or efficacy outcomes and supported the use of these treatments for newly-diagnosed patients (5). The ABCD considered, however, that switching patients on treatment should not be done automatically (neither at the hospital, general practice [GP] or pharmacy level) and should only be conducted under properly trained clinical teams (5). In line with this and NHS England's Commissioning Framework, a number of regional and local authorities have put in place policies to promote the use of biosimilars, including insulin glargine. For instance, the South Staffordshire Area Prescribing Group (which includes several Clinical Commissioning Groups [CCGs]) published a statement underlining that they will "initiate new patients requiring insulin glargine on biosimilar Abasaglar ${ }^{\circledR}$ " (6). Also, several CCGs have issued clear guidance 
on how to switch patients on Lantus ${ }^{\circledR}$ to Abasaglar ${ }^{\circledR}$, and even calculated the savings that could be realised from this change (7-11).

In general, however, the CCG Biosimilar National Questionnaire results suggest that CCGs put more emphasis on the development of uptake plans for biosimilars used in secondary care; for instance, $98 \%$ and $96 \%$ of CCGs confirmed having developed plans for commissioning infliximab and etanercept biosimilars for new patients, with only $3 \%$ of CCGs indicating that similar strategies had been put in place for insulin glargine biosimilars (12). Therefore, a considerable amount of potential savings may have been missed, particularly in primary care, the healthcare setting where diabetes patients are regularly treated and followed-up (13). For this reason, the main objective of our analysis was to estimate the real-world adoption rates and budget impact, or savings, of insulin glargine biosimilars in primary care in England, as well as the savings that may have been missed since their launch. In addition, we assessed whether insulin glargine biosimilar adoption rates varied across CCGs and attempted to identify if different prescribing policies may have led to any potential differences.

\section{METHODS}

\section{Data}

In the interest of good governance and public accountability, the UK Government have committed to increase transparency in the public sector in recent years, including making publicly available GP practice level prescribing data [14]. On May $21^{\text {st }}, 2019$, we extracted the data on each individual treatment (identified by a unique British National Formulary code) prescribed by each GP practice in England and dispensed in the community in the UK. Prescribing information datasets were available monthly, recording data starting from August 2010 until December 2018 (at the time of data collection). We filtered these datasets to capture prescriptions of insulin glargine prescribed by brand name and excluded those where insulin glargine was prescribed generically; the products and presentations included in the analyses are described in Table 4.1. The datasets captured a small number of Lantus OptiSet ${ }^{\circledR}$ and Lantus OptiClik ${ }^{\circledR}$ prescriptions, but these were excluded from the analyses due to the manufacturer's decision to discontinue their commercialisation following the advice from the National Patient Safety Agency in 2010 [15]. Toujeo DoubleStar ${ }^{\circledR}$ and Semglee ${ }^{\circledR}$ (insulin glargine biosimilars) were not captured in our dataset due to the time limits (i.e. December 2018). 
Table 4.1. Products included in the analysis.

\begin{tabular}{|c|c|c|c|}
\hline Product & Presentation & $\begin{array}{l}\text { Reference } \\
\text { or } \\
\text { biosimilar? }\end{array}$ & $\begin{array}{l}\text { If biosimilar, } \\
\text { corresponding reference } \\
\text { product }\end{array}$ \\
\hline Lantus $\AA$ & 100 units $/ \mathrm{ml}$ in $3-\mathrm{ml}$ cartridges & Reference & - \\
\hline Lantus ${ }^{\circledR}$ & 100 units $/ \mathrm{ml}$ in $10-\mathrm{ml}$ vials & Reference & - \\
\hline Lantus ${ }^{\circledR}$ & $\begin{array}{l}\text { SoloStar }(100 \text { units } / \mathrm{ml} \text { in } 3-\mathrm{ml} \\
\text { pre-filled pens }\end{array}$ & Reference & - \\
\hline Toujeo $®$ & $\begin{array}{l}300 \text { units } / \mathrm{ml} \text { in } 1.5-\mathrm{ml} \text { pre-filled } \\
\text { SoloStar pens }\end{array}$ & Reference & - \\
\hline Abasaglar ${ }^{\circledR}$ & 100 units $/ \mathrm{ml}$ in $3-\mathrm{ml}$ cartridges & Biosimilar & $\begin{array}{l}\text { Lantus }{ }^{\circledR}, 100 \text { units } / \mathrm{ml} \text { in } \\
\text { 3-ml cartridges }\end{array}$ \\
\hline Abasaglar ${ }^{\circledR}$ & $\begin{array}{l}\text { KwikPen }{ }^{\circledR}: 100 \text { units } / \mathrm{ml} \text { in } 3-\mathrm{ml} \\
\text { pre-filled pens }\end{array}$ & Biosimilar & $\begin{array}{l}\text { Lantus SoloStar }{ }^{\circledR}, 100 \\
\text { units/ml in } 3-\mathrm{ml} \text { pre-filled } \\
\text { pens }\end{array}$ \\
\hline
\end{tabular}

Among other variables, our datasets captured the total number of units (i.e. cartridges, pens or vials) of each product and each presentation of insulin glargine prescribed by each GP practice, as well as the net ingredient cost (i.e. the list price as stated in the Drug Tariff) and actual cost (i.e. actual drug acquisition costs, calculated as the list price, or net ingredient cost, minus an approximate discount plus payment for consumables, containers and out-of-pocket expenses) for the payer (i.e. the NHS) associated with these. Each GP practice was identified by a unique practice code and an additional field indicated the CCG to which each GP practice belonged. All prescribing data are also available to the public through a user-friendly interface (OpenPrescribing.net) developed at the University of Oxford [16].

\section{Analyses}

Firstly, we calculated the total number of units prescribed of each product and presentation, over time, by GPs in England. To understand the market dynamics following the adoption of biosimilars, we calculated the country-level market share of each product and presentation, over time, as the proportion of the total units prescribed. We also analysed the evolution of the actual cost per unit to understand whether certain changes in actual cost of treatments have resulted following the commercialisation of biosimilars. 
Then we estimated the real-world budget impact, or savings, resulting from the adoption of insulin glargine biosimilars by GPs in England. For this, we calculated the total actual costs of insulin glargine in our datasets (i.e. the total costs in the real world) and compared these with the hypothetical scenario in which insulin glargine biosimilars were not available, by replacing the cost of biosimilar prescriptions with the cost of the corresponding reference product (Table 4.1). Additionally, we estimated the missed savings with a threshold analysis, i.e. comparing the total actual costs in the real world with the hypothetical scenario in which insulin glargine biosimilars had a market share of $100 \%$. In other words, to estimate the missed savings we assumed that access to Abasaglar ${ }^{\circledR}$ would have been available to all relevant patients in England after the first GP-prescribed Abasaglar ${ }^{\circledR}$. We consider this to be a valid assumption for this hypothetical scenario analysis as, in theory, all CCGs in England could have made the decision to commission Abasaglar ${ }^{\circledR}$ as quickly as the quickest CCG. Because Toujeo ${ }^{\circledR}$ is an insulin glargine marketed as 300 units $/ \mathrm{ml}$, compared with the 100 units $/ \mathrm{ml}$ of the other insulin glargine products, it was not considered for potential substitution in the threshold analysis.

We created choropleth maps to observe the uptake of insulin glargine biosimilars at the CCG level and to visually assess whether differences exist across CCGs. The choropleth maps presented here show the proportion of Abasaglar KwikPen ${ }^{\circledR}$ from the total 3-ml pre-filled pen prescriptions (i.e. the sum of Abasaglar KwikPen ${ }^{\circledR}$ and Lantus SoloStar ${ }^{\circledR}$ prescriptions). We downloaded CCG boundary data from the Open Geography portal of the Office of National Statistics; boundary data from 2015 were used due to the lack of completeness of the 2016, 2017 and 2018 datasets. Finally, in order to better understand the reasons that may be driving potential differences in the uptake of insulin glargine biosimilars across CCGs, we submitted two Freedom of Information (FOI) requests to two CCGs with markedly different adoption rates. With these FOI requests, we asked whether the CCGs had put in place any policies to incentivise the use of biosimilars and insulin glargine biosimilars in particular.

\section{RESULTS}

Our results show that Lantus SoloStar ${ }^{\circledR}$ was the insulin glargine product most frequently prescribed by GPs in England, with nearly 6,000,000 units prescribed in 2018, compared with the nearly $1,400,000$ units of Lantus ${ }^{\circledR}$ cartridges, the second most prescribed product (Table 4.2). Nevertheless, the market share of Lantus SoloStar ${ }^{\circledR}$ decreased substantially from $80 \%$ just before the introduction of Toujeo ${ }^{\circledR}$ and Abasaglar ${ }^{\circledR}$ (particularly KwikPen ${ }^{\circledR}$ ) in late 2015 to $60 \%$ in December 2018 (Table 4.2; see 
Supplementary Materials for further information). By December 2018, Toujeo ${ }^{\circledR}$ and Abasaglar KwikPen ${ }^{\circledR}$ reached a market share of approximately $10 \%$ and $8 \%$, respectively (see Supplementary Materials).

The analysis of actual costs of insulin glargine showed that these have been maintained relatively steady in the last few years, with a considerable reduction in the case of Lantus ${ }^{\circledR}$ in 2018 (Table 4.2; see Supplementary Materials for further information). The actual cost of Lantus SoloStar ${ }^{\circledR}$ to the English NHS (£7.01 per pen) was, in December 2018, closer to that of Abasaglar KwikPen ${ }^{\circledR}$ ( $£ 6.55$ per pen) than ever before, which represents savings of $£ 0.46$ per pen (or 6.6\%) with Abasaglar KwikPen ${ }^{\circledR}$ compared with Lantus SoloStar®. 
Table 4.2. Total units, total costs and actual cost per unit of insulin glargine in primary care in England since the introduction of insulin glargine biosimilars.

\begin{tabular}{|c|c|c|c|c|c|}
\hline & 2015 & 2016 & 2017 & 2018 & $\begin{array}{c}\text { Total: } \\
\text { 2015-2018 }\end{array}$ \\
\hline \multicolumn{6}{|l|}{ Total units } \\
\hline $\begin{array}{l}\text { Abasaglar }{ }^{\circledR} 100 \mathrm{u} / \mathrm{ml} \text { cartridges } \\
(3 \mathrm{ml})\end{array}$ & 214 & 11,973 & 40,406 & 64,086 & 116,679 \\
\hline $\begin{array}{l}\text { Abasaglar KwikPen }{ }^{\circledR} 100 \mathrm{u} / \mathrm{ml} \\
\text { pens }(3 \mathrm{ml})\end{array}$ & 1,131 & 66,540 & 287,331 & 571,320 & 926,322 \\
\hline Lantus ${ }^{\circledR} 100 \mathrm{u} / \mathrm{ml}$ cartridges $(3 \mathrm{ml})$ & $1,569,162$ & $1,616,568$ & $1,518,500$ & $1,382,872$ & $6,087,102$ \\
\hline Lantus ${ }^{\circledR} 100 \mathrm{u} / \mathrm{ml}$ vials $(10 \mathrm{ml})$ & 48,709 & 47,804 & 42,045 & 36,882 & 175,440 \\
\hline $\begin{array}{l}\text { Lantus SoloStar }{ } 100 \mathrm{u} / \mathrm{ml} \text { pens } \\
(3 \mathrm{ml})\end{array}$ & $6,395,711$ & $6,493,615$ & $6,257,381$ & $5,959,478$ & $25,106,185$ \\
\hline Toujeo® $300 \mathrm{u} / \mathrm{ml}$ pens $(1.5 \mathrm{ml})$ & 9,703 & 183,632 & 485,377 & 818,117 & $1,496,829$ \\
\hline \multicolumn{6}{|l|}{ Total costs $(\mathfrak{f})$} \\
\hline $\begin{array}{l}\text { Abasaglar }{ }^{\circledR} 100 \mathrm{u} / \mathrm{ml} \text { cartridges } \\
(3 \mathrm{ml})\end{array}$ & 1,396 & 78,287 & 264,164 & 419,789 & 763,636 \\
\hline $\begin{array}{l}\text { Abasaglar KwikPen }{ }^{\circledR} 100 \mathrm{u} / \mathrm{ml} \\
\text { pens }(3 \mathrm{ml})\end{array}$ & 7,381 & 435,216 & $1,878,904$ & $3,743,194$ & $6,064,695$ \\
\hline Lantus ${ }^{\circledR} 100 \mathrm{u} / \mathrm{ml}$ cartridges $(3 \mathrm{ml})$ & $12,046,224$ & $12,425,823$ & $11,674,629$ & $10,014,635$ & $46,161,311$ \\
\hline Lantus ${ }^{\circledR} 100 \mathrm{u} / \mathrm{ml}$ vials $(10 \mathrm{ml})$ & $1,382,180$ & $1,358,124$ & $1,194,763$ & 987,773 & $4,922,840$ \\
\hline $\begin{array}{l}\text { Lantus SoloStar } \AA 100 \mathrm{u} / \mathrm{ml} \text { pens } \\
(3 \mathrm{ml})\end{array}$ & $49,102,727$ & $49,916,502$ & $48,112,182$ & $43,147,088$ & $190,278,499$ \\
\hline Toujeo® $300 \mathrm{u} / \mathrm{ml}$ pens $(1.5 \mathrm{ml})$ & 99,124 & $1,878,858$ & $4,965,681$ & $8,386,202$ & $15,329,865$ \\
\hline \multicolumn{6}{|l|}{ Actual cost per unit (f) } \\
\hline $\begin{array}{l}\text { Abasaglar }{ }^{\circledR} 100 \mathrm{u} / \mathrm{ml} \text { cartridges } \\
(3 \mathrm{ml})\end{array}$ & 6.53 & 6.54 & 6.54 & 6.55 & - \\
\hline $\begin{array}{l}\text { Abasaglar KwikPen }{ }^{\circledR} 100 \mathrm{u} / \mathrm{ml} \\
\text { pens }(3 \mathrm{ml})\end{array}$ & 6.53 & 6.54 & 6.54 & 6.55 & - \\
\hline Lantus ${ }^{\circledR} 100 \mathrm{u} / \mathrm{ml}$ cartridges $(3 \mathrm{ml})$ & 7.68 & 7.69 & 7.69 & 7.24 & - \\
\hline Lantus ${ }^{\circledR} 100 \mathrm{u} / \mathrm{ml}$ vials $(10 \mathrm{ml})$ & 28.38 & 28.41 & 28.42 & 26.78 & - \\
\hline $\begin{array}{l}\text { Lantus SoloStar }{ }^{\circledR} 100 \mathrm{u} / \mathrm{ml} \text { pens } \\
(3 \mathrm{ml})\end{array}$ & 7.68 & 7.69 & 7.69 & 7.24 & - \\
\hline Toujeo ${ }^{\circledR} 300 \mathrm{u} / \mathrm{ml}$ pens $(1.5 \mathrm{ml})$ & 10.22 & 10.23 & 10.23 & 10.25 & - \\
\hline
\end{tabular}


Table 4.3 shows the budget impact, or savings, associated with the introduction of insulin glargine biosimilars in primary care in England. The total savings with Abasaglar $\AA$ between October 2015 (the time of the first captured Abasaglar $\AA$ prescription) and December 2018 were approximately $£ 900 \mathrm{~K}$, most of which was due to the adoption of KwikPen ${ }^{\circledR}$. The total missed savings in England, however, amounted to approximately $£ 25.6 \mathrm{M}$. With this, the results showed that the percentage of savings realised with the introduction of insulin glargine biosimilars was $3.42 \%$ of the total savings that could have been achieved in the period analysed.

Table 4.3. Real-world savings and missed savings with insulin glargine biosimilars in primary care in England.

\begin{tabular}{|c|c|c|c|c|c|}
\hline & 2015 & 2016 & 2017 & 2018 & $\begin{array}{l}\text { Total: } \\
\text { 2015-2018 }\end{array}$ \\
\hline \multicolumn{6}{|l|}{ Savings } \\
\hline 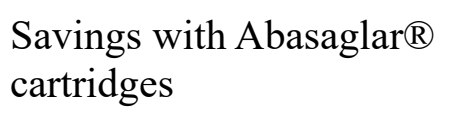 & 246 & 13,744 & 46,488 & 44,316 & 104,794 \\
\hline $\begin{array}{l}\text { Savings with Abasaglar } \\
\text { KwikPen }{ }^{\circledR}\end{array}$ & 1,303 & 76,278 & 330,346 & 393,208 & 801,135 \\
\hline $\begin{array}{l}\text { Total savings with } \\
\text { Abasaglar }{ }^{\circledR}\end{array}$ & 1,549 & 90,022 & 376,834 & 437,524 & 905,929 \\
\hline \multicolumn{6}{|l|}{ Missed savings } \\
\hline $\begin{array}{l}\text { Missed savings with } \\
\text { Abasaglar } ® \text { cartridges }\end{array}$ & 450,257 & $1,855,735$ & $1,747,052$ & 956,270 & $5,009,314$ \\
\hline $\begin{array}{l}\text { Missed savings with } \\
\text { Abasaglar KwikPen }{ }^{\circledR}\end{array}$ & $1,837,423$ & $7,443,899$ & $7,194,153$ & $4,101,579$ & $20,577,054$ \\
\hline $\begin{array}{l}\text { Total missed savings with } \\
\text { Abasaglar }{ }^{\circledR}\end{array}$ & $2,287,680$ & $9,299,635$ & $8,941,205$ & $5,057,849$ & $25,586,369$ \\
\hline $\begin{array}{l}\text { Percentage of savings } \\
\text { realised }\end{array}$ & $0.07 \%$ & $0.96 \%$ & $4.04 \%$ & $7.96 \%$ & $3.42 \%$ \\
\hline
\end{tabular}

Our analyses demonstrated that the uptake of insulin glargine biosimilars varied substantially across CCGs, but no clear geographical pattern emerged (Figure 4.1). The NHS Swindon CCG was the quickest CCG to adopt insulin glargine biosimilars, with 
an average of $7.4 \%$ of use of Abasaglar KwikPen ${ }^{\circledR}$ (from the total 3-ml pre-filled pen prescriptions) across GP practices in December 2015. The uptake of Abasaglar KwikPen ${ }^{\circledR}$, over time, was unequal across England, with NHS North and West Reading CCG leading the uptake of Abasaglar KwikPen ${ }^{\circledR}$ in December 2016 (26.9\%) and NHS Kernow CCG in December 2017 (40.2\%). In December 2018, NHS Swindon CCG and NHS Kernow CCG were the CCGs with the highest use of insulin glargine biosimilars (53.3\% and 51.4\%, respectively), followed by NHS Berkshire West, which included the former NHS North and West Reading CCG (41.2\%) (Figure 4.1; the "missing data" were not actually missing, but due to the evolution of CCGs and lack of complete boundary data associated with these changes we were not able to present all the data in the map). On the other hand, in December 2018 the use of Abasaglar KwikPen ${ }^{\circledR}$ was zero in nine CCGs, with a total of 28 CCGs below a $1 \%$ use. Choropleth maps of Abasaglar KwikPen ${ }^{\circledR}$ uptake in December 2015, December 2016 and December 2017 are available in Supplementary Materials.

One FOI request was submitted to NHS Kernow CCG (one of the CCGs with the highest insulin glargine biosimilar use) and the response to our request stated that NHS Kernow CCG has not incentivised an increase in the use of biosimilars in Cornwall, nor more specifically has it incentivised the uptake of biosimilar insulin glargine. It was confirmed, however, that the CCG supported the review of all people with diabetes who are prescribed analogue insulin and a switch to a biosimilar if appropriate and acceptable to the individual. We submitted another FOI request to South Sefton CCG (one of the CCGs with an uptake rate of insulin glargine biosimilars of $0 \%$ ), but the response only mentioned that agreeing on policies around biosimilars is part of the CCG's work plan for $2019 / 2020$. 
Figure 4.1. Market share of Abasaglar KwikPen®, from the total 3-ml pre-filled pen prescriptions, in December 2018.






\section{CONCLUSIONS}

\section{Summary of findings}

Our analyses showed that the total savings with Abasaglar ${ }^{\circledR}$ between October 2015 (the time of the first Abasaglar ${ }^{\circledR}$ prescription) and December 2018 were approximately $£ 900 \mathrm{~K}$, which represents $3.42 \%$ of the total savings that could have been realised in the period analysed. In other words, approximately savings of $£ 25.6 \mathrm{M}$ on drug acquisition costs were missed from not using insulin glargine biosimilars in that period, assuming full access to Abasaglar ${ }^{\circledR}$ in primary care in England, ceteris paribus. The extent of future savings and missed savings will depend on a number of variables such as price adjustments, the entry of competitor biosimilars and the subsequent market dynamics, and incentives to clinicians and patients, but our results provide a valuable idea of the range of future realised and missed savings. Our analyses also demonstrated that a substantial level of variation in the use of insulin glargine biosimilars exists across CCGs in England, ranging from $0 \%$ to $53.3 \%$ in the case of Abasaglar KwikPen ${ }^{\circledR}$. The information gathered from the two FOI requests did not provide sufficient clarification as to why this level of variation exists between one of the CCGs with highest insulin glargine biosimilar use and one of the CCGs with the lowest use.

\section{Strengths and limitations}

In recent years, the UK Government have made public a large amount of data to encourage analysis and innovation, including detailed, monthly datasets on treatments prescribed by GP practices in England [14]. Using these rich datasets represents the key strength of our study and, with this, not only did we shed light on an issue with relevant implications at the policy level, but we contributed towards the very purpose of making all these datasets available to the public. In addition, our study provides a framework that can be updated regularly to evaluate the uptake and variation of any particular treatment across GPs in England and to promote policies that ensure equitable access to healthcare; this framework could be used at either national, regional or local level.

Our study, however, also had certain limitations. A number of medical associations and regulatory agencies, including the Medicines and Healthcare Products Regulatory Agency in the UK, have stated that all biological medicines must be prescribed by brand name to avoid automatic substitution at the pharmacy level [2]. The GP practice level prescribing data, however, captured a considerable number of insulin glargine prescriptions (13.3\%) without a brand name associated with the given prescription record. For this reason, and to prevent potential errors, we focused on those records with an associated brand name and removed the rest from our analyses. Therefore, our results are likely to be an underestimation of the real budget impact as well as an 
underestimation of the total missed savings. On the other hand, our study only considered drug acquisition costs and did not account for potential costs of switching patients from originators to biosimilars, such as the costs of regularly monitoring blood glucose levels or potential nocebo effects, meaning that the savings we estimated will likely be reduced in practice by these extra costs $[17,18]$. Switching costs have been shown to be substantial in other disease areas, but managed biosimilar switch programmes have also been successfully implemented in the UK despite this additional burden [19-21]. Although it is expected that switching costs will not exceed the savings realised by an increased use of insulin glargine biosimilars, the lack of data on switching prevents us from assessing this in detail.

The lack of patient-level data was another limitation, as we were not able to assess any potential associations between the use of specific treatments (e.g. the uptake of insulin glargine biosimilars) and patients' characteristics. This was an unavoidable limitation resulting from the nature of the dataset. Finally, the responses to our FOI requests did not provide the extent of detail we were hoping for, limiting our ability to understand whether policies for access to insulin glargine biosimilars varied across CCGs and what may be driving the observed differences.

\section{Policy-level implications}

As part of the UK Government's Long-Term Plan (LTP) for the NHS, the NHS announced savings of $£ 700 \mathrm{M}$ have been achieved in 2018/2019 as a consequence of maximising the use of best value generic and biologic treatments [22]. A significant proportion of this figure came from the uptake of adalimumab biosimilars after Humira ${ }^{\circledR}$ lost its patent protection in October 2018: the increased use of adalimumab biosimilars delivered savings of approximately $£ 110 \mathrm{M}$ in 2018/2019 [22]. Other biologic treatments also contributed substantially to these savings: $£ 45 \mathrm{M}$ with the best value rituximab; $£ 36 \mathrm{M}$ with the best value etanercept; $£ 32 \mathrm{M}$ with the best value infliximab; and £24M with the best value trastuzumab [22]. Unfortunately, no data was reported on savings with insulin glargine biosimilars either in primary or secondary care, which was in line with the results from the CCG Biosimilar National Questionnaire suggesting that most CCGs only develop plans for the most frequently used biosimilars in secondary care. The reality is that savings with insulin glargine biosimilars in primary care (approximately $£ 900 \mathrm{~K}$ between October 2015 and December 2018) are minor compared with those of the best value adalimumab, rituximab, etanercept, infliximab and trastuzumab; it is also true, however, that the savings missed from not using insulin glargine in primary care in 2018 ( $£ 5.1 \mathrm{M}$; Table 4.3) are at the level of the savings realised in 2018/2019 with the uptake of generics such as caspofungin (£8.5M), 
valganciclovir (£3.8M) or voriconazole (£7.0M), as per the NHS LTP report [22].

Regulatory and reimbursement agencies affirm that no clinically meaningful differences exist between originators and biosimilars and, at the same time, the NHS have encouraged the use of the best value biologic treatment $(1 ; 23 ; 24)$. In spite of this, considerable barriers exist for the adoption of biosimilars and, as a consequence, for achieving all potential savings $(13 ; 25)$. For instance, a survey in UK hospitals concluded that physicians' perception of efficacy and safety was crucial, showing that only $30 \%$ of diabetologists had no concern for starting treatment with insulin glargine biosimilars or switching treatment for patients already on treatment (25). This could be justified by the incidents reported when switching patients from Lantus ${ }^{\circledR}$ to Abasaglar ${ }^{\circledR}$, posing an additional hurdle for a smooth uptake of insulin glargine biosimilars and the concerns regarding medical liability (26-29). In addition, the ABCD stated there is a real problem in diabetes care regarding the "lack of knowledge" among healthcare professionals about the characteristics of existing treatments, with biosimilar insulins adding to this complexity (5). The sparse evidence base comparing biosimilar insulins with their originators is a significant barrier contributing to this "lack of knowledge" $(28 ; 29)$. Patients' perceptions and resistance to changing treatments may also play a role. A patient survey conducted in Canada demonstrated that patients remain resistant to switching to biosimilars, which has implications on treatment adherence and subsequently on patient outcomes (30); despite differences between the Canadian and English healthcare systems, similar results may be expected in England. With all this, better and proactive education programmes about biosimilars for both clinicians and patients have been considered crucial to increase the use of biosimilars (28). Other barriers may include the costs of switching patients from Lantus ${ }^{\circledR}$ to an insulin glargine biosimilar (e.g. having prescribing pharmacists in GP practices, referring the patient to a specialist in a hospital or having to closely monitor patients' blood glucose) and the fact that CCGs may simply focus on those molecules with the greatest potential to deliver substantial savings in a short period of time (13). The launch of Toujeo ${ }^{\circledR}$ and its quick uptake may have also played a role in limiting the use of insulin glargine biosimilars.

According to the Commissioning framework for biological medicines, there is a significant opportunity to further benefit from biosimilar medicines if action is taken across the country and best practice is implemented (2). For this reason, and in order to optimise the use of NHS resources, implement best practice and reduce unwarranted variation, Regional Medicines Optimisation Committees (RMOC) were established in 2016 (23). The role of RMOC is to provide advice to commissioner (such as CCGs) s and providers and, in turn, these are expected to follow and implement RMOC advice 
(23). One example of advice is the one released by the Guilford and Waverley RMOC in December 2016, who recommended the use of "Abasaglar ${ }^{\circledR}$ for new patients who would previously have been initiated on Lantus ${ }^{\circledR}$ " (31). Initiating diabetes patients on insulin glargine biosimilars seems to be an accepted approach that budget holders across England are promoting; however, there is more resistance to switch stable patients currently on Lantus ${ }^{\circledR}(13 ; 27)$. A survey in UK hospitals revealed that diabetologists in secondary care believe that switching to insulin glargine biosimilars should be done by GPs in primary care, as it would be the primary care budget that would benefit (13). But switching patients and realising savings will be limited if the appropriate structure and incentives do not exist. Apart from following the advice given by RMOC, the NHS and CCGs may need to put in place certain incentive schemes to promote the uptake of biosimilars in primary care, such as reinvesting the savings within the CCG or practice that realised the savings; putting in place supporting staff to incentivise the uptake of insulin glargine biosimilars, as done by the Mid Essex CCG; or extending the Quality and Outcomes framework to include items on the use biosimilars in primary care (2; 13). In case a wider implementation of incentive schemes such as these prove successful, current manufacturers would have to adapt their strategies to remain key players in the field; further pricing adjustments would be likely, and biosimilar manufacturers would need to adapt their production levels to avoid potential drug shortages and maintain their reputation.

The atlas developed by the NHS Business Service Authority (i.e. Medicines Optimisation Dashboard) illustrates that variations in prescribing rates exist across NHS Trusts in the use of biosimilars of etanercept, infliximab, rituximab and trastuzumab [29]. For instance, in July 2018, the uptake of infliximab biosimilars ranged from 51\% (in Bradford Teaching Hospitals NHS Foundation Trust) to 100\% in several trusts; also in July 2018 , the uptake of etanercept, rituximab and trastuzumab varied between $0 \%$ and $100 \%$ across NHS trusts. Similar results were reported by other studies that used the GP practice level prescribing data to analyse variations (across CCGs) in other products' prescription rates, indicating that inequalities in prescription rates may be widespread across primary care in England [30-32]. Our results corroborate this reality: it seems that patients in certain areas are more likely to be initiated on or switched to insulin glargine biosimilars compared with other areas. This adds further evidence to the postcode lottery issue in England [33,34]. Although we tried to decipher some of the key determinants of the variation in the uptake of insulin glargine biosimilars by submitting two FOI requests, this was not the key focus of our analysis and remains a topic of future research. 


\section{Summary}

Two key conclusions can be drawn from this analysis: firstly, there are considerable savings that are not being realised and, secondly, there is substantial variation in the use of insulin glargine biosimilars across CCGs in England. We believe that the results from our analyses will encourage decision-makers in England, as well as healthcare managers in other settings, to promote a coordinated approach to the use of best value treatments in primary care and to re-evaluate variation in treatment patterns across GP practices and CCGs. Because switching to biosimilars is not just about generating savings, but about creating budget headroom for an increased access to best value treatments for all patients.

\section{ACKNOWLEDGEMENTS}

All authors (IA, ESI, KM and JMC) designed the work; IA collected, cleaned and analysed the data; IA drafted the manuscript; all authors revised and approved the work prior to submission. The corresponding author confirms that all authors meet authorship criteria and that no others meeting the criteria have been omitted. IA is the guarantor of this work and, as such, had full access to all the data in the study and takes responsibility for the integrity of the data and the accuracy of the data analysis. This research did not receive any grant from funding agencies in the public, commercial or non-for-profit sectors. All authors declare no conflict of interest. 


\section{REFERENCES}

1. Biosimilar medicines: Overview [article online], 2017. Available from https://www.ema.europa.eu/en/humanregulatory/overview/biosimilar-medicines-overview. Accessed October 24th 2019

2. Medicines, Diagnostics and Personalised Medicine Policy Team, National Medical Directorate, NHS England. Commissioning framework for biological medicines (including biosimilar medicines). 2017

3. Biosimilars of insulin glargine [article online], 2018. Available from http://gabionline.net/Biosimilars/General/Biosimilarsof-insulin-glargine. Accessed October 24th 2019

4. Annex I. Summary of Product Characteristics (Lantus) [article online], Available from https://www.ema.europa.eu/en/documents/product-information/lantus-epar-product-information_en.pdf. Accessed October 31st 2019

5. Jayagopal V, Drummond R, Nagi D. Association of British Clinical Diabetologists (ABCD) position statement on the use of biosimilar insulin. The British Journal of Diabetes 2018;18:171-174

6. Biosimilar insulins [article online], 2017. Available from http://www.southstaffordshirejointformulary.nhs.uk/docs/misc/Biosimilar\%20insulins\%20FINAL.pdf. Accessed October 24th 2019

7. Insulin glargine biosimilar Abasaglar ${ }^{\circledR}$ [article online], 2016. Available from https://westessexccg.nhs.uk/yourhealth/medicines-optimisation-and-pharmacy/clinical-guidelines-and-prescribing-formularies/06-endocrine-system/81mopb-decision-insulin-glargine-abasaglar/file. Accessed October 24th 2019

8. Potential Lantus to Abasaglar switch for adult T2DM patients [article online], 2017. Available from http://www.southworcsccg.nhs.uk/EasySiteWeb/GatewayLink.aspx?alId=141095. Accessed October 24th 2019

9. Stephenson L. Prescribing commissioning policy for biosimilar insulin Semglee. North East Essex Clinical Commissioning Group, 2019

10. Dudley Diabetes Management Guidelines for Adults with Type 2 Diabetes [article online], 2019. Available from http://www.dudleyformulary.nhs.uk/download/96/diabetes-guidelines. Accessed October 30th 2019

11. Guildford And Waverley Joint Formulary [article online], 2019. Available from http://www.guildfordandwaverleyformulary.nhs.uk/chaptersSubDetails.asp?FormularySectionID=6\&SubSectionRef=06. 01\&SubSectionID=A100. Accessed October 30th 2019

12. CCG National Questionnaire Report [article online], 2018. Available from https://www.sps.nhs.uk/wpcontent/uploads/2018/10/CSUs_CCGsBiosimilarsUptakeSurveyApril2018.pdf. Accessed October 24th 2019

13. Aladul MI, Fitzpatrick RW, Chapman SR. Healthcare professionals' perceptions and perspectives on biosimilar medicines and the barriers and facilitators to their prescribing in UK: a qualitative study. BMJ open 2018;8

14. Practice Level Prescribing Data [article online], 2018. Available from https://digital.nhs.uk/data-andinformation/publications/statistical/practice-level-prescribing-data. Accessed May 21st 2019

15. Sanofi-Aventis withdraws some insulin pens [article online], 2010. Available from https://www.diabetes.org.uk/about_us/news_landing_page/sanofi-aventis-withdraws-some-insulin-pens. Accessed October 24th 2019

16. OpenPrescribing.net [article online], 2017. Available from https://openprescribing.net/. Accessed January 26 th 2018 
17. Kravvariti E, Kitas GD, Mitsikostas DD, Sfikakis PP. Nocebos in rheumatology: emerging concepts and their implications for clinical practice. Nature reviews Rheumatology 2018;14:727-740

18. Odinet JS, Day CE, Cruz JL, Heindel GA. The Biosimilar Nocebo Effect? A Systematic Review of Double-Blinded Versus Open-Label Studies. Journal of managed care \& specialty pharmacy 2018;24:952-959

19. Chan A, Kitchen J, Scott A, Pollock D, Marshall R, Herdman L. Implementing and delivering a successful biosimilar switch programme - the Berkshire West experience. Future Healthc J 2019;6:143-145

20. Saxby K, Sanghvi S, Bodalia PN, Ferner RE, Leandro M, Urquhart R, Sofat R. A novel approach to support implementation of biosimilars within a UK tertiary hospital. British journal of clinical pharmacology 2019;

21. Tarallo M, Onishchenko K, Alexopoulos ST. Costs associated with non-medical switching from originator to biosimilar etanercept in patients with rheumatoid arthritis in the UK. Journal of medical economics 2019;22:1162-1170

22. NHS cuts medicines costs by three quarters of a billion pounds [article online], 2019. Available from https://www.england.nhs.uk/2019/08/nhs-cuts-medicines-costs-by-three-quarters-of-a-billion-pounds/. Accessed October 29th 2019

23. Regional Medicines Optimisation Committees [article online], Available from https://www.england.nhs.uk/medicines/regional-medicines-optimisation-committees/. Accessed October 29th 2019

24. Diabetes mellitus type 1 and type 2: insulin glargine biosimilar (Abasaglar) [article online], 2015. Available from https://www.nice.org.uk/advice/esnm64/chapter/Key-points-from-the-evidence. Accessed October 31st 2019

25. Chapman SR, Fitzpatrick RW, Aladul MI. Knowledge, attitude and practice of healthcare professionals towards infliximab and insulin glargine biosimilars: result of a UK web-based survey. BMJ open 2017;7:e016730

26. Patient safety update/ Medication safety officer (MSO) report (Q1 2019) [article online], 2019. Available from https://www.npa.co.uk/wp-content/uploads/2019/05/NPA-MSO-report-Q1-2019.pdf. Accessed October 29th 2019

27. Rocco P, Selletti S, Minghetti P. Biosimilar switching and related medical liability. Journal of forensic and legal medicine 2018;55:93-94

28. Greener M. Why isn't the NHS making the most of biosimilar insulin? Prescriber 2019;30:21-24

29. Tieu C, Lucas EJ, DePaola M, Rosman L, Alexander GA-O. Efficacy and safety of biosimilar insulins compared to their reference products: A systematic review.

30. Wong-Rieger D. Changes in Patient Knowledge, Attitudes and Usage Preferences Regarding Biosimilars: Focus on Diabetes. Canadian Journal of Diabetes 2018;42:S26

31. Profile : Insulin Glargine (Abasaglar) - Diabetes Mellitus [article online], 2019. Available from https://surreyccg.ressystems.net/PAD/Search/DrugConditionProfile/5225. Accessed October 30th 2019

32. Medicines Optimisation Dashboard [article online], 2019. Available from https://apps.nhsbsa.nhs.uk/MOD/AtlasTrustsMedsOp/atlas.html. Accessed October 29th 2019

33. Walker AJ, Curtis HJ, Bacon S, Croker R, Goldacre B. Trends, geographical variation and factors associated with prescribing of gluten-free foods in English primary care: a cross-sectional study. BMJ open 2018;8:e21312

34. Agirrezabal I, Cabases JM, Di Tanna GL, Sanchez-Iriso E. Inequalities in prescription rates of anti-osteoporosis drugs in primary care in England: A practice-level prescribing data analysis in 2013-2018. Bone 2019;130:115125

35. Green K, Cooke O'Dowd N, Watt H, Majeed A, Pinder RJ. Prescribing trends of gabapentin, pregabalin, and oxycodone: a secondary analysis of primary care prescribing patterns in England. BJGP open 2019;3

36. Iacobucci G. NHS England tells CCGs to end postcode lottery over diabetes glucose devices. BMJ (Clinical research ed) 
2018;363:k4812

37. Torjesen I. Analysis shows "postcode lottery" in access to GPs in England. BMJ (Clinical research ed) 2014;348:g3688 
SUPPLEMENTARY MATERIAL

Figure S1. Market shares of insulin glargine products in primary care in England.




Figure S2. Actual cost of insulin glargine products in primary care in England.

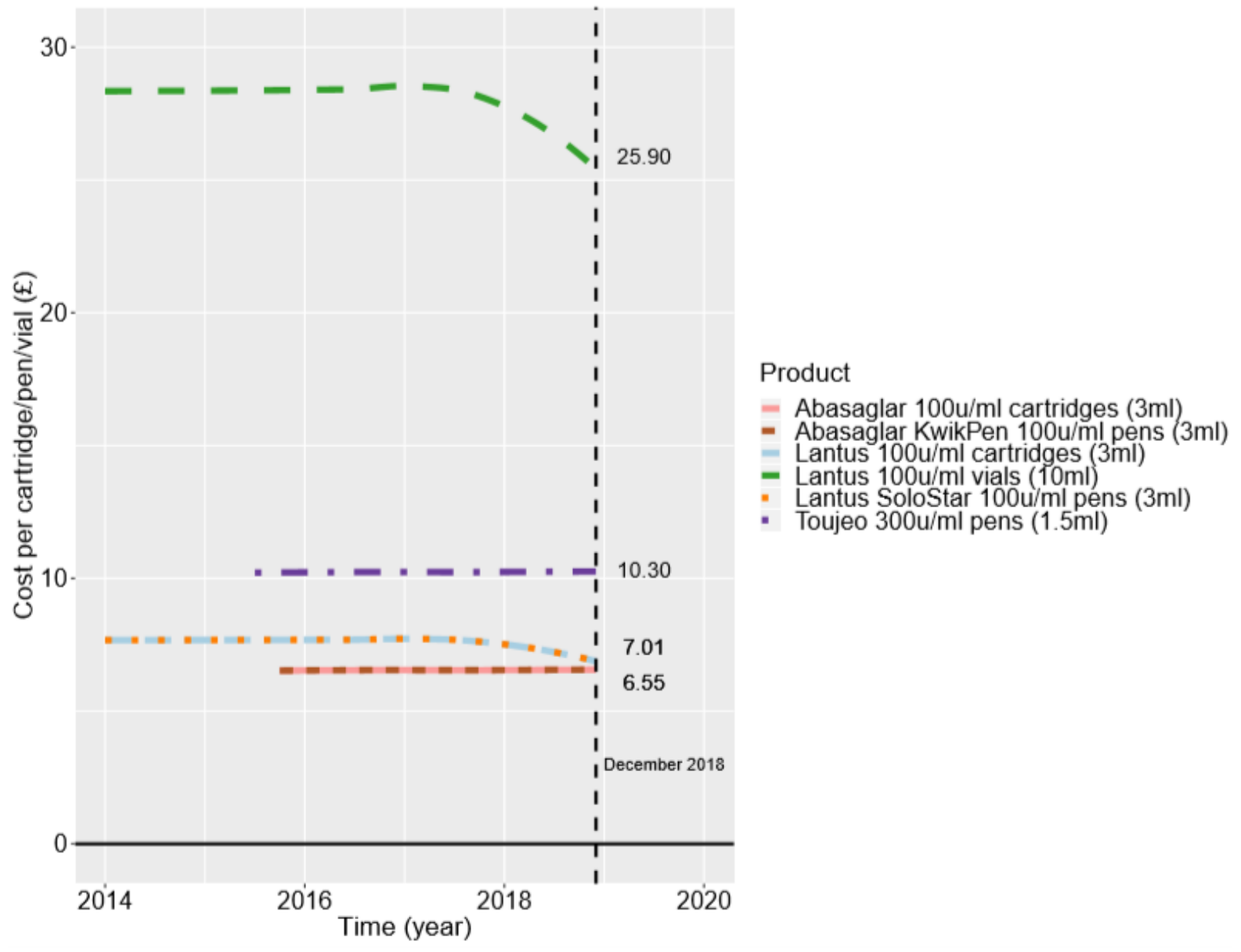


Figure S3. Market share of Abasaglar KwikPen®, from the total 3-ml pre-filled pen prescriptions, in December 2015.

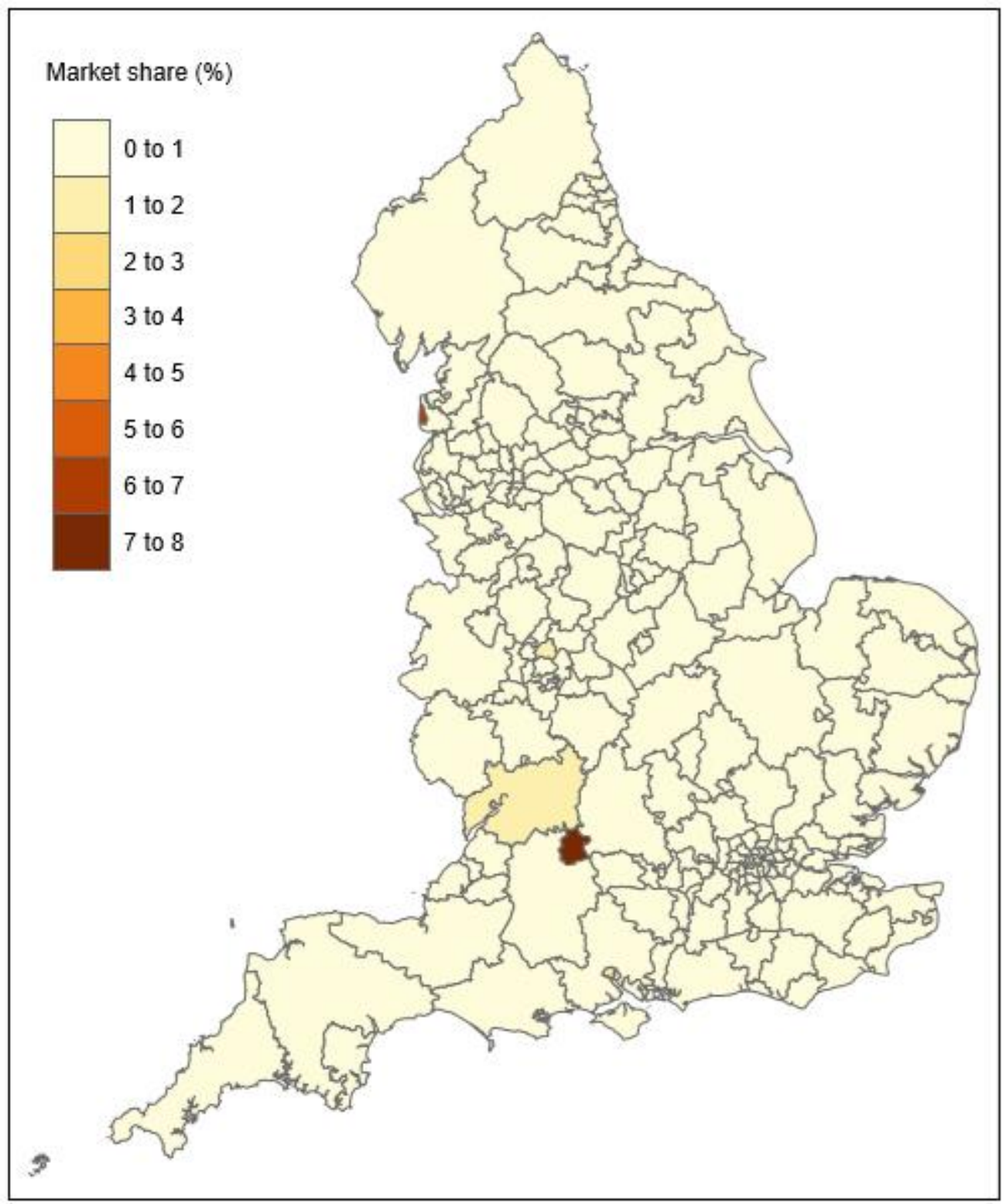


Figure S4. Market share of Abasaglar KwikPen®, from the total 3-ml pre-filled pen prescriptions, in December 2016.

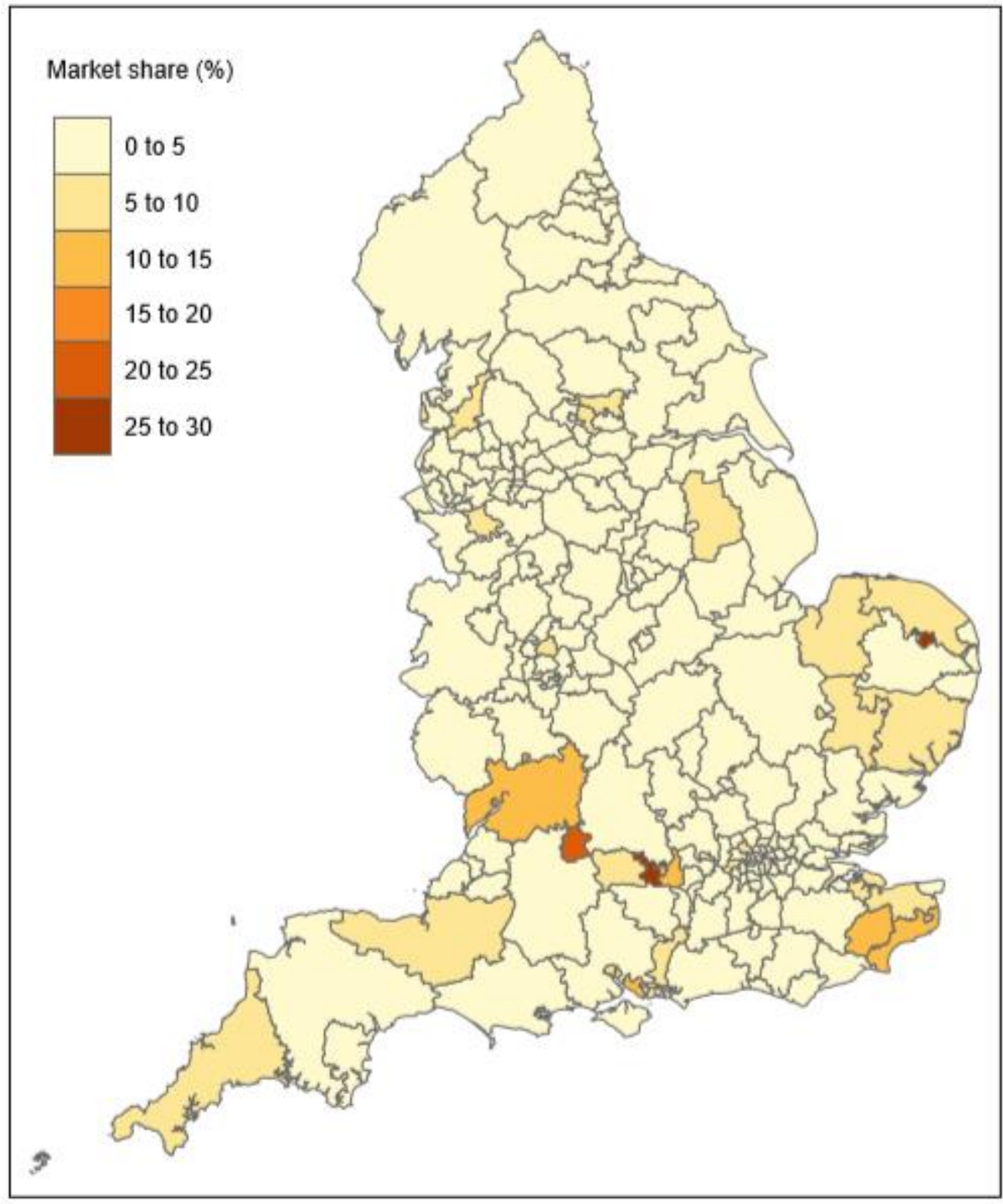


Figure S5. Market share of Abasaglar KwikPen®, from the total 3-ml pre-filled pen prescriptions, in December 2017.

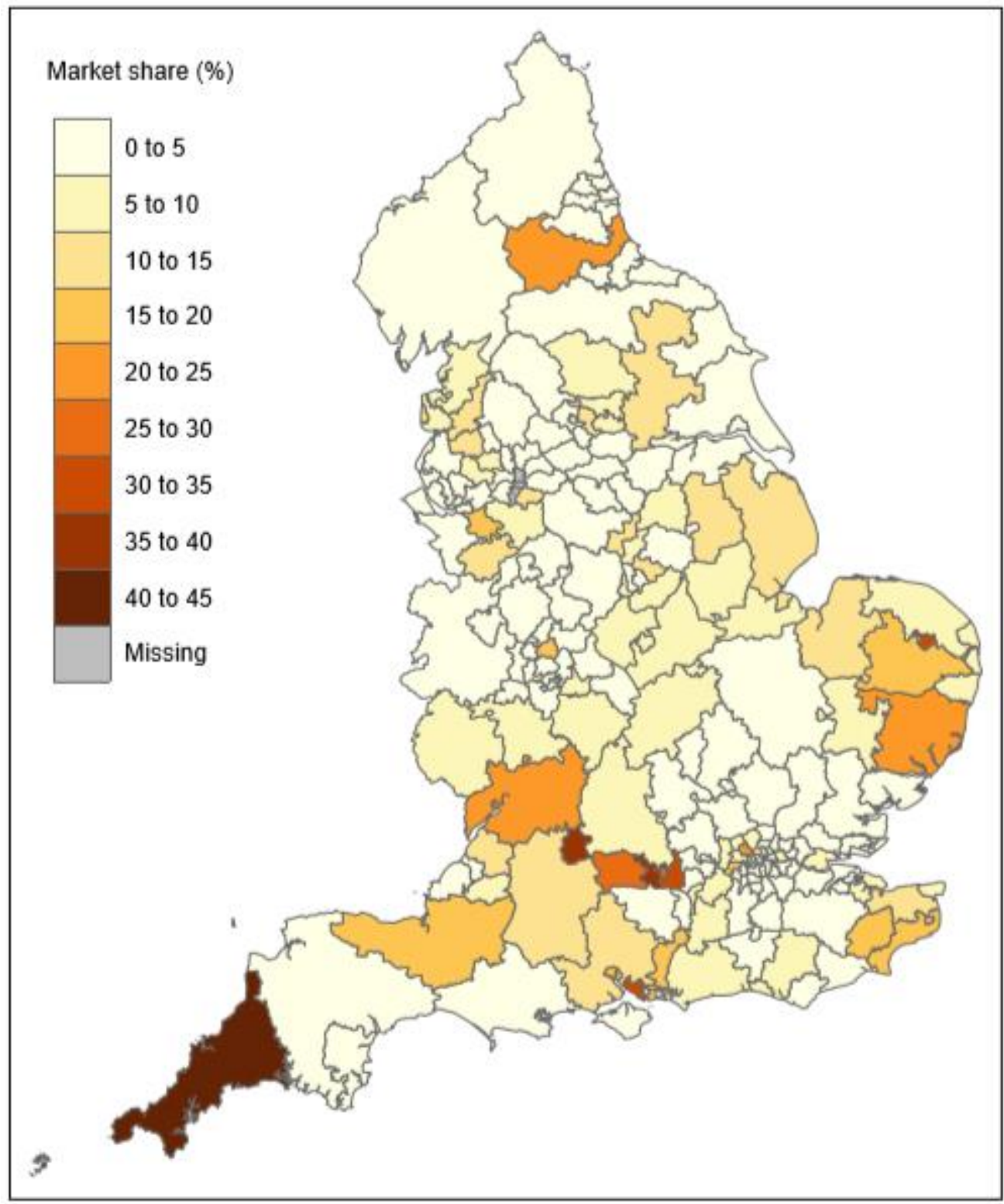


Publication details: Diabetes Care. 2020 Jun 11;dc192395. doi: 10.2337/dc19-2395. Online ahead of print.

Impact factor: $15.27(2018)$

Authors: Ion Agirrezabal (ORCID: 0000-0003-3170-7845)a, Eduardo Sánchez-Iriso (ORCID: 0000-0002-5320-8732)a, Kiran Mandarb, Juan M Cabasés (ORCID: 0000-0003-0207-4137)a

\section{Affiliations:}

${ }^{a}$ Department of Economics, Public University of Navarre, 31006 Pamplona/Iruña, Spain

${ }^{\mathrm{b}}$ NHS England Specialised Commissioning, London Region, United Kingdom

Correspondence to: Ion Agirrezabal; Email: ion.agirrezabal@unavarra.es; Phone: 0034948166205

Other email addresses: Eduardo Sánchez-Iriso: eduardo.sanchez@unavarra.es; Kiran Mandar: kiranmandar@hotmail.com; Juan M Cabasés: jmcabases@unavarra.es

Declaration of interest: All authors declare no relationships or activities that could appear to have influenced the submitted work.

Funding: None.

Note: Table and figure numbers are not shown as submitted for publication. These have been updated to show the chapter number in this thesis. 
Chapter 5

Future research directions 
In the health economics literature, there has been a debate over whether currently used methods of economic evaluation are appropriate for appraising advanced therapy medicinal products (ATMPs), some experts arguing that existing frameworks may not be the most suitable means of assessment [1]. Given the lack of evidence base to inform long-term efficacy and safety assumptions associated with ATMPs, it is important to fully consider the uncertainty around all critical inputs in economic models of ATMPs. Also, it is crucial for budget holders to understand the implications of reimbursing ATMPs under the traditional payment methods or, alternatively, whether the implementation of new payment models (e.g. performance-based arrangements or leasing schemes) could mitigate the risks of paying for such high-cost treatments [2].

Features of ATMPs and the supporting evidence base that might limit the validity of conventional economic modelling methods and assumptions include:

- Discounting: using traditional payment methods health systems would have to face high upfront costs with ATMPs, whereas benefits would be accrued over time. In that case, discount rates would have a considerably larger effects on benefits compared with costs. For this reason, health technology assessment (HTA) agencies such as the National Institute for Health and Care Excellence (NICE) have suggested that a discount rate of $1.5 \%$ may be appropriate in cases that meet certain conditions [3].

- Extrapolation of treatment effects: regulatory approvals may be based on clinical trials of relatively short duration, creating uncertainty in the understanding of long-term treatment effects and therefore posing a substantial financial risk to payers.

- Time horizon: with potential curative effects, lifetime horizons might best demonstrate the value of ATMPs, but might be challenging to justify based on clinical trials of limited duration.

- Assessment of value: as ATMPs may provide benefits substantially larger than those typically seen in HTA, there is a lack of clarity as to whether there are facets of value beyond classic health gain measures that should be considered $[2,4]$.

One of the diseases for which ATMPs and, more specifically, gene therapies can bring a significant benefit is haemophilia A. Haemophilia $\mathrm{A}$ is a rare genetic disorder characterised by the deficiency of the clotting Factor VIII in the blood, which may lead to excessive bleeding from injuries and surgeries, as well as pain, swelling and limitation of movement [5]. A recent study quantified the costs of severe haemophilia in Europe at approximately $€ 200,000$ per patient per year and highlighted the importance of the indirect impact of haemophilia on the patient and caregivers [6]. 
As far as we know, two economic models analysing the cost-effectiveness of gene therapies in haemophilia have been published to date, both from the US healthcare payer perspective $[7,6]$. Both models compared a gene therapy vs. standard of care, consisting of prophylactic Factor VIII [7,6]. In terms of model structure, however, these two models present a key difference: one was a Markov model whereas the other was a microsimulation model $[7,6]$.

Our plan is to replicate the microsimulation model, as such a structure would provide the opportunity to appropriately capture heterogeneity among individuals regarding key inputs (e.g. duration of response and costs) [7]. Following this, we plan to fully analyse the uncertainty of all key variables in model results in order to understand the values that these would need to take in order to reach certain cost-effectiveness or budget impact results. We will focus our efforts in those variables that have been deemed critical for the evaluation of ATMPs (e.g. discounting, extrapolation of treatment effect or time horizon) and will shed light on how these affect economic model results. Also, we will implement various innovative payment methods to gauge, from both the manufacturer and payer perspective, how different payment mechanisms would affect cash flows. With this, we would like to assist all stakeholders in a fair evaluation of the upcoming wave of high-cost, most innovative technologies and ensure that all payment options are appropriately studied and discussed so that these treatments eventually reach those in need. 


\section{REFERENCES}

1. Marsden, G., Towse, A.: Exploring the Assessment and Appraisal of Regenerative Medicines and Cell Therapy Products: Is the NICE Approach Fit for Purpose? https:/www.ohe.org/publications/exploring-assessment-and-appraisal-regenerativemedicines-and-cell-therapy-products\# (2017). Accessed February 3rd 2020

2. Jönsson, B., Hampson, G., Michaels, J., Towse, A., von der Schulenburg, J.M.G., Wong, O.: Advanced therapy medicinal products and health technology assessment principles and practices for value-based and sustainable healthcare. Eur J Health Econ 20(3), 427-438 (2019). doi:10.1007/s10198-018-1007-x

3. National Institute for Health and Care Excellence: Interim Process and Methods of the Highly Specialised Technologies Programme Updated to reflect 2017 changes. https://www.nice.org.uk/Media/Default/About/what-we-do/NICEguidance/NICE-highly-specialised-technologies-guidance/HST-interim-methods-process-guide-may-17.pdf (2017). Accessed February 3rd 2020

4. Chambers, J., Silver, M.C., Lin, P.J., Cohen, J.T., Paramore, C., Baumann, S., Neumann, P.J.: PMU77 CELL AND GENE THERAPIES ARE ASSOCIATED WITH SUBSTANTIALLY LARGER QUALITY-ADJUSTED LIFE YEAR GAINS THAN CONVENTIONAL DRUGS AND BIOLOGICS. Value in Health 22, S263 (2019). doi:10.1016/j.jval.2019.04.1238

5. The Haemophilia Society: Haemophilia A. https://haemophilia.org.uk/bleeding-disorders/haemophilia-a/. Accessed February 3 rd 2020

6. O'Hara, J., Hughes, D., Camp, C., Burke, T., Carroll, L., Diego, D.-A.G.: The cost of severe haemophilia in Europe: the CHESS study. Orphanet J Rare Dis 12(1), 106-106 (2017). doi:10.1186/s13023-017-0660-y

7. Cook, K., Forbes, S.P., Adamski, K., Ma, J.J., Chawla, A., Garrison, L.P., Jr.: Assessing the potential cost-effectiveness of a gene therapy for the treatment of hemophilia A. J Med Econ, 1-1 (2020). doi:10.1080/13696998.2020.1721508 
Chapter 6

Concluding remarks 
- Healthcare decision-makers can use and combine the power of randomised controlled trials (RCTs) with real-world evidence (RWE) to maximise the possibilities of making a good decision under uncertain conditions. The importance of such an approach lays in the fact that healthcare budgets are increasingly tight and the sizable pipeline of high-cost drugs lining up to come to market in the coming years. In our example, we used both data sources (RCTs and RWE) to demonstrate that the reimbursement of KRd (the combination of carfilzomib, lenalidomide and dexamethasone) for multiple myeloma patients is likely to represent an efficient allocation of available resources.

- Nevertheless, the distribution of innovative drugs across the population may not be fair nor efficient. With our analyses we demonstrated that significant variation or inequalities exist in the anti-osteoporosis drugs prescription levels across the English primary care. These inequalities are particularly striking in the case of denosumab, a high-cost monoclonal antibody, with prescriptions disproportionately concentrated in the less deprived areas in England. We believe our results should be a cause of concern for healthcare authorities, prompting them to take the necessary steps to prevent obvious situations of inequality in access to not only anti-osteoporosis treatments but all other therapies.

- Similarly, we demonstrated that even though guidelines and initiatives to promote the use of biosimilars exist, their uptake in England is not being as swift and successful as could have been expected, at least for certain products. Our study reveals that, since the insulin glargine biosimilar was launched in 2015, the savings generated in the English primary care is only a small proportion of the potential savings that could have been generated. These results indicate that the implementation of guidelines that promote the use of biosimilars in primary care is not being straightforward and, consequently, the treatments that bring highest value to the health system may not be being used. In addition, we observed substantial variations in the use of insulin glargine biosimilars across England, with certain regions showing a high market share whereas biosimilars were nonexistent in others. The use of biosimilars could contribute to the availability of resources that may be allocated to other innovative treatments and, consequently, differences in the uptake of biosimilars across regions may cause differences in the probability of access to innovative treatments. This is yet another example of inequalities in the access to therapy and stresses the need to take the necessary steps to guarantee equity in access and long-term sustainability of the healthcare system.

- All three projects demonstrate the power of combining high-quality, large data 
sources, and the value that results from thorough data analyses can provide. We are witnessing just the beginning of the data analytics era and we hope that our approaches can be used by others in the future to present the scientific community with ideas that will make our health systems more equitable and efficient.

- In summary, even though in many cases ample evidence exists to assist healthcare authorities making resource allocation decisions, we have demonstrated that resource allocation in the real world may not be optimal. We hope that our methods and results provide useful insights so that healthcare authorities, in England but also in other countries, adopt measures that ensure the key objective of our healthcare systems is achieved: to improve the average level of the population health and to reduce health inequalities in the population. 
- Osasun-sistemako erabakitzaileek ziurtasunik gabeko egoeretan erabaki honak har ditzaten aukerak maximizatzeko honako informazio iturriak ustia eta konbina ditzakete: entsegu kliniko aleatorioak (EKA) eta mundu errealeko ebidentzia (MEE). Erabakitzaileek erabilgarri duten aurrekontua geroz eta murritzagoa izanik, eta kostu altuko terapien eskaintza geroz eta zabalagoa izanik, eskuragarri dagoen jakinduria guztia ahalik eta modurik egokienean erabiltzea geroz eta garrantzitsuagoa bilakatzen ari da. Gure adibidean, bai EKA baita MEE erabilita, mieloma anizkuna duten pazienteak tratatzeko KRd (karfilzomib, lenalidomida eta dexametasonaren konbinazioa) erabiltzea eskuragai dauden baliabideen esleipen egokia izan litekeela erakutsi dugu.

- Hala ere, litekeena da sendagai berritzaile hauek populazioari modu ez-eraginkor eta zuzengabean eskaintzea. Gure analisiek frogatu dutenez, bariazio edo desparekotasun esanguratsuak existitzen dira osteoporosia tratatzeko sendagaien preskripzio-mailan Ingalaterran. Desparekotasun hauek bereziki adierazgarriak dira denosumaben kasuan, kostu altuko antigorputz monoklonala, zeinen preskripzio mailarik altuenak, Ingalaterran, gabezia edo beharrik baxuena duten eskualdeetan biltzen diren. Gure ustetan emaitza hauek kezkagarri beharko lukete osasungintza sektoreko agintariendako, horrelako desparekotasun egoerak ekiditeko neurriak hartzera bultzatuz.

- Era berean ikusi dugu biosimilarren erabilera sustatzeko eta kostu altuko sendagaien ondoriozko aurrekontu-inpaktuaren eragina minimizatzeko gidak publikatu eta iniziatibak aurrera eramanda ere, biosimilarren erabilera tasa merkatu ingelesean ez dela hasiera batean pentsa litekeena bezain zabala, produktu batzuen kasuan behinik behin. Gure analisien arabera, 2015. urtean insulina glarginaren biosimilarra merkaturatu zenetik, gauza litezkeen aurrezkietatik proportzio txiki bat besterik ez da gauzatu. Gure emaitzen arabera, biosimilarren erabilera sustatzeko existitzen diren gidek proposatzen dituzten arauak eguneroko bizitzan ezartzeko zailtasunak daude eta, ondorioz, osasun sistemari balore handieneko sendagaien erabilera ez da behar bezalakoa. Gainera, insulina glarginaren biosimilarren erabilera maila nabarmen aldatzen da Ingalaterrako eskualdetik eskualdera, batzuetan merkatu-kuota altua izatetik beste batzuetan inolako erabilerarik ez izatera. Biosimilarrak erabiltzeak baliabide gehiago eskuragarri izatea ekar lezake, beste sendagai berritzaile batzuk erabiltzera bidera litezkeenak eta, honela, eskualdeen arteko desberdrintasunen ondorioz baliteke sendagai berritzaileak jasotzeko probabilitatea altuagoa izatea eskualde batzuetan beste batzuetan baino. Hau, beraz, desparekotasunaren beste adibide bat da eta ekitatea eta sistemaren epe 
luzeko jasangarritasuna bermatzeko ekimenak behar-beharrezkoak direla argi uzten du.

- Hiru proiektu hauek kalitatezko datu base handiak konbinatu eta sakonki analizatzeak duen balioa agerian uzten dute, Datuen analisiaren aro berriaren hasiera besterik ez da hau eta espero dugu etorkizuneko ikerlariek, gure metodoak erabilita akaso, osasun-sistema ekitatibo eta eraginkorragoak izateko ideia berriak plazaratzea.

- Laburbilduz, kasu askotan erabakitzaileek bide egokia hautatzeko nahikoa ebidentzia izan arren, litekeena da praktikan baliabideen esleipena eta erabilpena optimoa ez izatea. Espero dugu gure metodo eta emaitzek, bai Ingalaterrako baita gainontzeko herrialdeetako agintariendako ere, informazio baliagarria eskaintzea gure osasun-sistemen helburu nagusia betetzeko beharrezko diren neurriak hartzeko bidean, honela populazioaren osasuna hobetu eta desparekotasun egoerak ekiditeko. 
- Los decisores del sistema sanitario tienen la posibilidad de utilizar y combinar el potencial de los ensayos clínicos aleatorios (ECAs) con la evidencia del mundo real (EMR) para maximizar las posibilidades de tomar una decisión correcta en situaciones de incertidumbre. Esto ha adquirido e irá adquiriendo más importancia en los próximos años si temenos en cuenta los cada vez más limitados presupuestos de los que disponen los decisores y la cada vez más amplia oferta de terapias de alto coste. En nuestro ejemplo, haciendo uso de las dos fuentes de información (ECAs y EMR), demostramos que el reembolso de KRd (la combinación de carfilzomib, lenalidomida y dexametasona) para pacientes de mieloma multiple supondría, probablemente, una asignación eficiente de los recursos disponibles.

- Sin embargo, la puesta en práctica y distribución en la población de medicamentos innovadores puede no ser justa ni eficiente. Con nuestros análisis demostramos que existen variaciones o desigualdades significativas en los niveles de prescripción de medicamentos para la osteoporosis en Inglaterra. Estas desigualdades son especialmente visibles en el caso de denosumab, anticuerpo monoclonal de alto coste, cuyas prescripciones se concentran de forma desproporcionada en las zonas menos desfavorecidas de Inglaterra. Creemos que estos resultados deberían preocupar a las autoridades sanitarias y que éstas deberían tomar las acciones necesarias para evitar situaciones claras de desigualdad no solamente en el área de la osteoporosis sino en todas las demás áreas.

- De la misma manera demostramos que, pese a que existan guías e iniciativas para promover el uso de biosimilares y así minimizar el impacto presupuestario generado por los medicamentos de alto coste, el acceso al mercado inglés no está siendo tan rápido y exitoso como cabría esperar, al menos para algunos productos. Nuestro estudio revela que, desde que se lanzó el biosimilar de insulina glargina en 2015, los ahorros que se han generado en Inglaterra son solamente una pequeña parte de lo que se podría haber ahorrado. Estos resultados indican que existe un problema de implantación de las guías para promover el uso de biosimilares en atención primaria y, en consecuencia, que no se están utilizando los medicamentos que más valor aportan al sistema sanitario. Además, observamos variaciones significativas en el uso de biosimilares de insulina glargina en Inglaterra, habiendo regiones con una alta cuota de mercado del producto y otras con una presencia inexistente del biosimilar. La penetración de biosimilares podría contribuir a la disponibilidad de recursos que podrían ser asignados a otros medicamentos innovadores y, en consecuencia, las diferencias 
existentes entre regiones podrían significar que la probabilidad de recibir otros medicamentos innovadores es mayor en unas regiones que en otras. Este es, por tanto, otro ejemplo de las desigualdades existentes en el acceso a los medicamentos que incide en la necesidad de tomar acciones para garantizar la equidad y la sostenibilidad del sistema a largo plazo.

- Estos tres proyectos demuestran el poder de combinar grandes bases de datos, de alta calidad, y resaltan el valor que los resultados de un análisis exhaustivo puede proporcionar. Estamos ante lo que es únicamente el principio de la era del análisis de datos, y esperamos que otros, tal vez utilizando nuestros métodos, presenten nuevas ideas en el future que lleven a nuestros sistemas de salud a ser más equitativos y eficientes.

- En resumen, a pesar de que en muchos casos haya suficiente evidencia para informar la toma de decisiones sobre la asignación de recursos a medicamentos innovadores, hemos demostrado que la asignación de recursos en la práctica puede no ser óptima. Esperamos que nuestros estudios aporten métodos y datos útiles para que las autoridades sanitarias, tanto en Inglaterra como en el resto del mundo, adopten medidas que nos lleven a asegurar que se cumple el objetivo principal de nuestros sistemas sanitarios: mejorar la salud de la población y evitar situaciones de desigualdad. 
Addendum 1

Key $R$ code scripts 


\section{Load Libraries}

library(data.table); library(curl); library(bitops)

library(dplyr)

library (ggplot2)

library(stringr)

library(tictoc)

library(readr)

library (gridExtra) 


\section{Download, manipulate and clean characteristics of patients registered at GP offices}

\# Code corresponding to "patient_characteristics.R" script

\#

\# This code calculates the mean age and percentage of females per GP practice at each time point, if data are available, or creates the datasets to later interpolate the data from the two closest available data points.

\# Change working directory to save the files at a different location (use "setwd")

\# Create a vector to capture the time points (as row number in the dataset) at which patient characteristics data are not available.

pat.data.NA <- vector $($ mode = "numeric", length $=0$ )

\# Create a vector to capture all postcodes among all datasets

postcode.data $<-$ vector $($ mode $=$ "character", length $=0$ )

\# Run for loop to create datasets of patient characteristics at the GP practice level

for (i in $1:$ n.observations) \{

if (! is.na(dataset\$GP_patients_females[i]) \&\& ! is.na(dataset\$GP_patients_males[i])) \{

\# Specify the availability of data and, if available, download the data.

\# Create an indicator (pat.availability) to specify the situation regarding the available data on the characteristics of the patient population.

pat. availability <- 1

link.f<- dataset\$GP_patients_females[i]; pat.data.f<- fread $($ input $=1$ ink.f, nrows = -1 , header $=$ TRUE, showProgress $=$ TRUE)

link.m <- dataset\$GP_patients_males[i]; pat.data.m <- fread(input = link.m, nrows = -1 , header = TRUE, showProgress $=$ TRUE)

rm(link.f, link.m)

\} else if (!is.na(dataset\$GP_patients_all_1y[i])) \{

pat. availability $<-2$

link <- dataset\$GP_patients_all_1y[i]; pat.data <- fread $($ input $=$ link, nrows = -1 , header = TRUE, showProgress = TRUE); pat.data <- tbl_df(pat.data)

$\mathrm{rm}($ link $)$

\} else if (!is.na(dataset\$GP_patients_all_5y[i])) \{

pat. availability $<-3$

link <- dataset\$GP_patients_all_5y[i]; pat.data <- fread $($ input $=$ link, nrows $=-1$, header $=$ TRUE, showProgress $=$ TRUE $)$; pat.data $<-$ tbl_df(pat.data $)$

$\mathrm{rm}($ link $)$ 


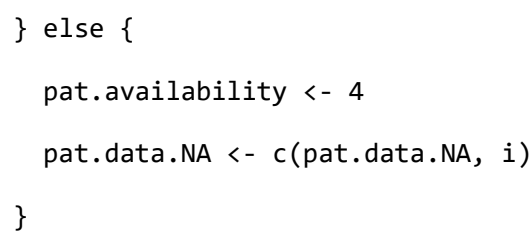

\# If pat.availability is either 1, 2 or 3, the code below manipulates the data to produce a consistent dataset reporting the mean age and the percentage of females in each GP practice.

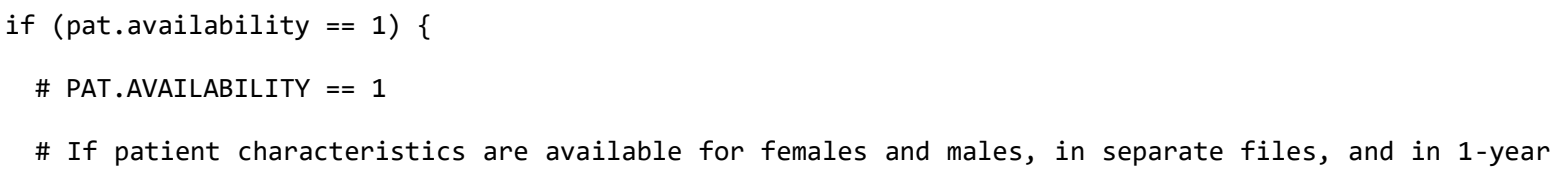




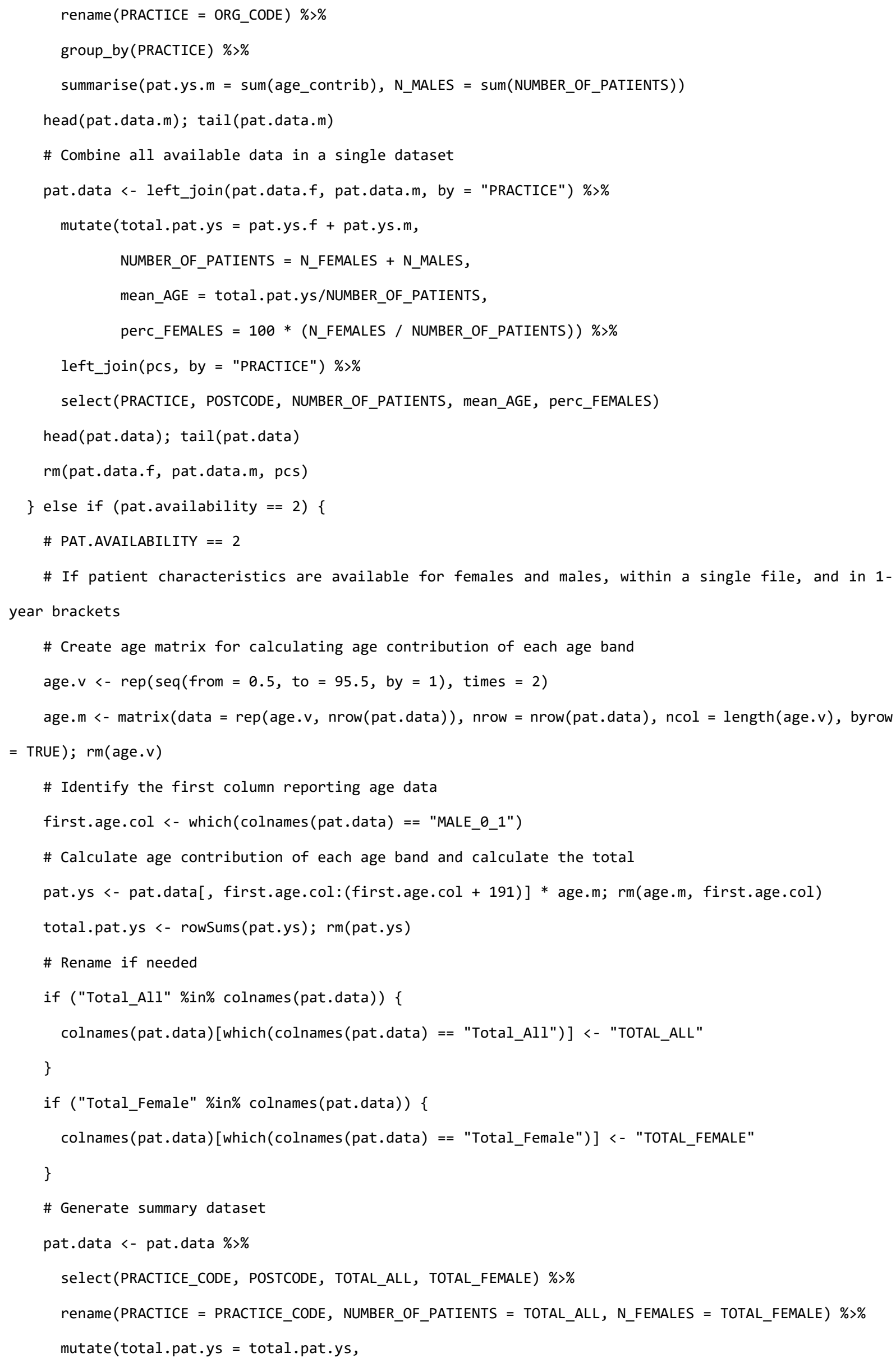




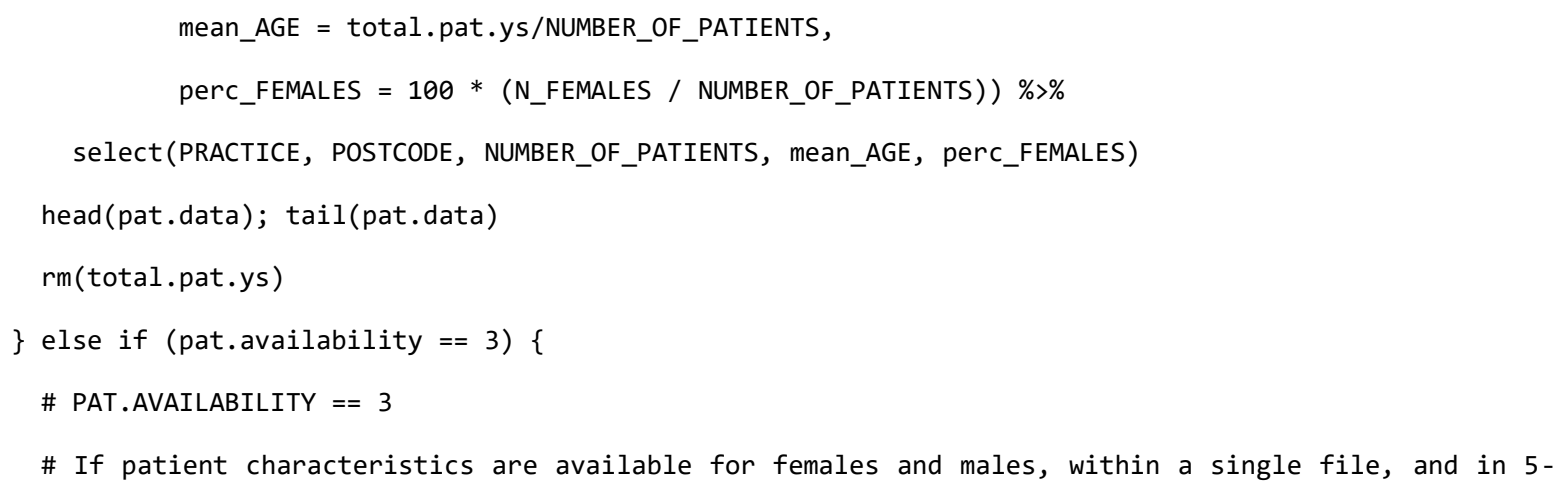




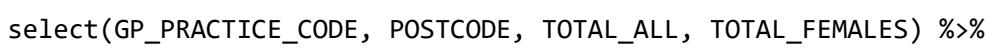

rename $($ PRACTICE $\quad=\quad$ GP_PRACTICE_CODE, NUMBER_OF_PATIENTS = TOTAL_ALL, N_FEMALES = TOTAL_FEMALES) \%>\%

mutate $($ total $\cdot$ pat.ys $=$ total.pat $\cdot y s$,

mean_AGE $=$ total.pat.ys/NUMBER_OF_PATIENTS,

perc_FEMALES $=100 *($ N_FEMALES / NUMBER_OF_PATIENTS $)) \%>\%$

select(PRACTICE, POSTCODE, NUMBER_OF_PATIENTS, mean_AGE, perc_FEMALES)

head(pat.data); tail(pat.data)

rm(total.pat.ys)

\} else $\{$ \# If postcode is not provided

pat.data <- pat.data $\%>\%$

select(GP_PRACTICE_CODE, TOTAL_ALL, TOTAL_FEMALES) \%>\%

rename $(P R A C T I C E=$ GP_PRACTICE_CODE, NUMBER_OF_PATIENTS = TOTAL_ALL, N_FEMALES =

TOTAL_FEMALES) $\%$ \%

mutate (total.pat.ys = total.pat.ys,

mean_AGE = total.pat.ys/NUMBER_OF_PATIENTS,

perc_FEMALES $=100 *($ N_FEMALES / NUMBER_OF_PATIENTS $)) \%>\%$

select(PRACTICE, NUMBER_OF_PATIENTS, mean_AGE, perc_FEMALES)

head(pat.data); tail(pat.data)

rm(total.pat.ys)

\}

\}

\# Create a .csv file from the pat.data dataset

\# All .csv files, i.e. for all months for which patient characteristics exist, will be initially created,

\# to allow interpolation of data for the time points for which these data are not available (i.e. pat. availability $==4$ )

if (pat.availability $!=4)\{$

filename <- paste0("pat.data_", dataset\$Year[i], dataset\$Month[i], ".csv")

write.csv(pat.data, file $=$ filename, row.names $=$ FALSE)

$\mathrm{rm}(\mathrm{filename})$

\# Create a file with all different postcodes among all datasets

if (pat.availability $!=4 \& \&$ ("POSTCODE" \%in\% colnames(pat.data))) \{

current.unique.postcode <- unique(pat.data\$POSTCODE)

postcode.data <- c(postcode.data, current.unique.postcode) 


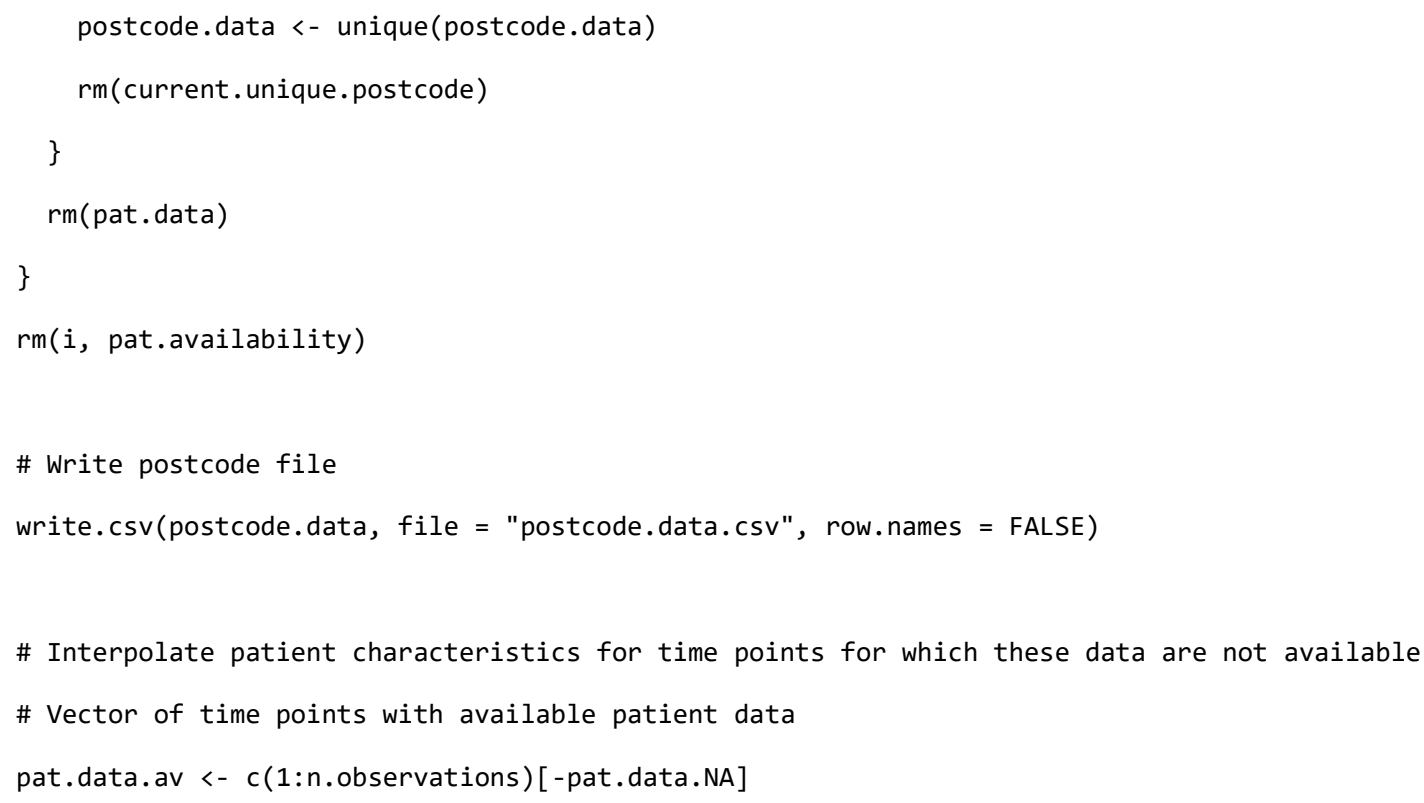

\# in the dataset. Then some of these may be dropped by the lack of prescription data in the prescribing 
datasets.

\# If postcode is provided in both datasets

if ("POSTCODE.x" \%in\% colnames(both.data) \&\& "POSTCODE.y" \%in\% colnames(both.data)) \{

both.data.na.rm <- both.data \%>

mutate(POSTCODE. $x=$ ifelse(is.na(POSTCODE.x), as.character (POSTCODE.y), as. character (POSTCODE.x)), NUMBER_OF_PATIENTS.x = ifelse(is.na(NUMBER_OF_PATIENTS.x), NUMBER_OF_PATIENTS.y, NUMBER_OF_PATIENTS.X),

mean_AGE.x $=$ ifelse(is.na(mean_AGE.x), mean_AGE.y, mean_AGE.x),

perc_FEMALES.x = ifelse(is.na (perc_FEMALES.x), perc_FEMALES.y, perc_FEMALES.x),

POSTCODE.y = ifelse(is.na(POSTCODE.y), as.character(POSTCODE.x), as.character(POSTCODE.y)), NUMBER_OF_PATIENTS.y = ifelse(is.na(NUMBER_OF_PATIENTS.y), NUMBER_OF_PATIENTS.x, NUMBER_OF_PATIENTS.y),

mean_AGE.y $=$ ifelse(is.na(mean_AGE.y), mean_AGE.x, mean_AGE.y),

perc_FEMALES.y $=$ ifelse(is.na(perc_FEMALES.y), perc_FEMALES.x, perc_FEMALES.y $)$ )

\} else \{

both.data.na.rm <- both.data \% \%

mutate(NUMBER_OF_PATIENTS.x = ifelse(is.na(NUMBER_OF_PATIENTS.x), NUMBER_OF_PATIENTS.y, NUMBER_OF_PATIENTS. $x$ ),

mean_AGE.x = ifelse(is.na(mean_AGE.x), mean_AGE.y, mean_AGE.x),

perc_FEMALES. $x=$ ifelse (is.na(perc_FEMALES.x), perc_FEMALES.y, perc_FEMALES. $x$ ),

NUMBER_OF_PATIENTS.y = ifelse(is.na(NUMBER_OF_PATIENTS.y), NUMBER_OF_PATIENTS.x, NUMBER_OF_PATIENTS.y),

mean_AGE.y $=$ ifelse(is.na(mean_AGE.y), mean_AGE.x, mean_AGE.y),

perc_FEMALES.y = ifelse(is.na (perc_FEMALES.y), perc_FEMALES.x, perc_FEMALES.y))

\}

rm(both.data)

\# Generation of the interpolated data.

if ("POSTCODE.x" \%in\% colnames(both.data.na.rm) \&\& "POSTCODE.y" \%in\% colnames(both.data.na.rm)) \{

interpol.d <- both.data.na.rm \%>\%

mutate(NUMBER_OF_PATIENTS $=$ round(NUMBER_OF_PATIENTS. $x+$ interpol. $f *$ (NUMBER_OF_PATIENTS.y NUMBER_OF_PATIENTS. $x), 0)$,

mean_AGE $=$ mean_AGE.x + interpol.f * (mean_AGE.y - mean_AGE.x $)$,

perc_FEMALES $=$ perc_FEMALES. $x+$ interpol.f $*($ perc_FEMALES. $y-$ perc_FEMALES.x $)) \%>\%$

rename $($ POSTCODE $=$ POSTCODE.$x)$

\} else \{

interpol.d <- both.data.na.rm \%>\%

mutate(NUMBER_OF_PATIENTS $=$ round(NUMBER_OF_PATIENTS. $x+$ interpol. $f *$ (NUMBER_OF_PATIENTS.y NUMBER_OF_PATIENTS. $x$ ), $\theta$ ), 


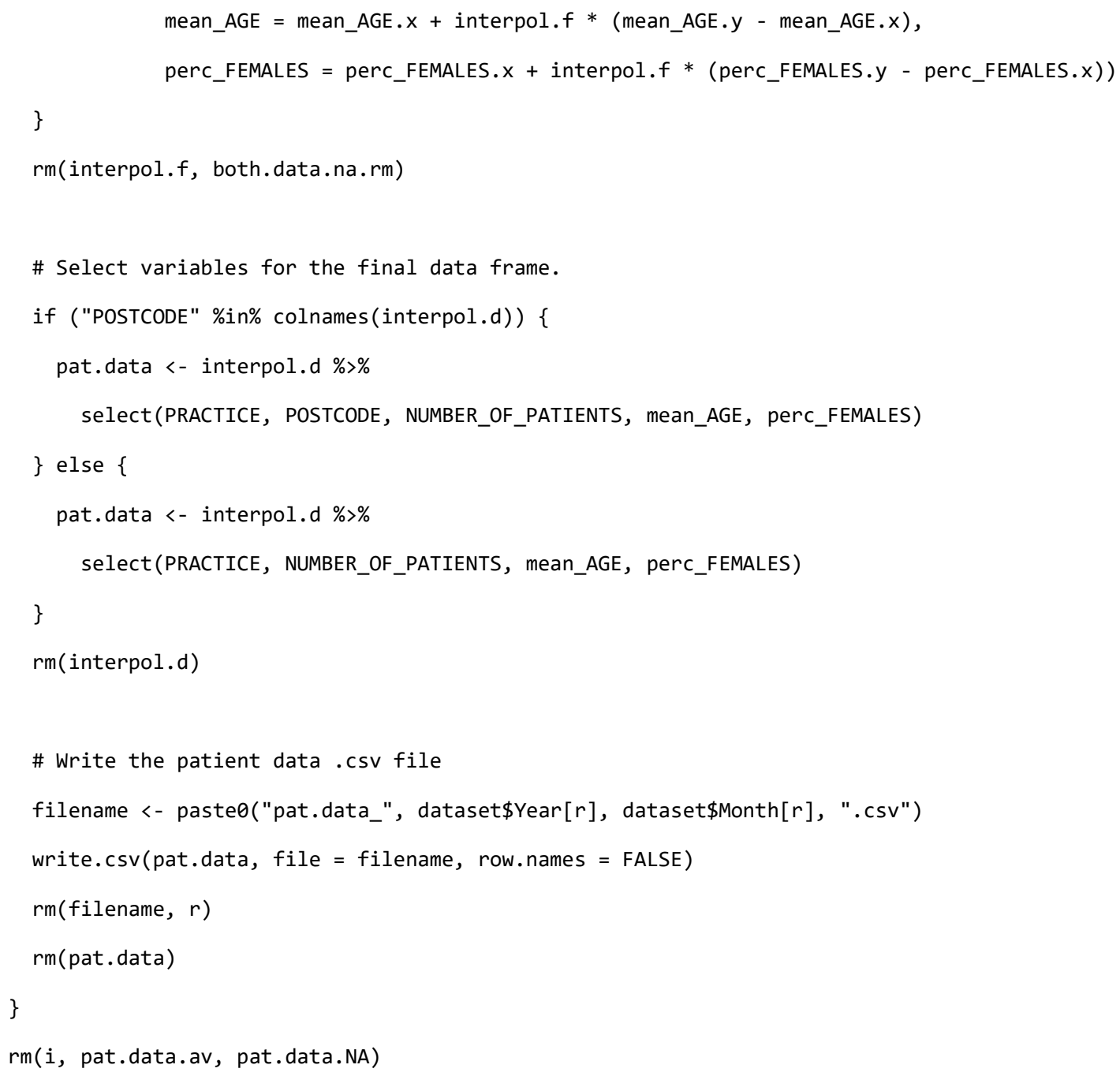




\section{Download, manipulate and clean GP prescribing data}

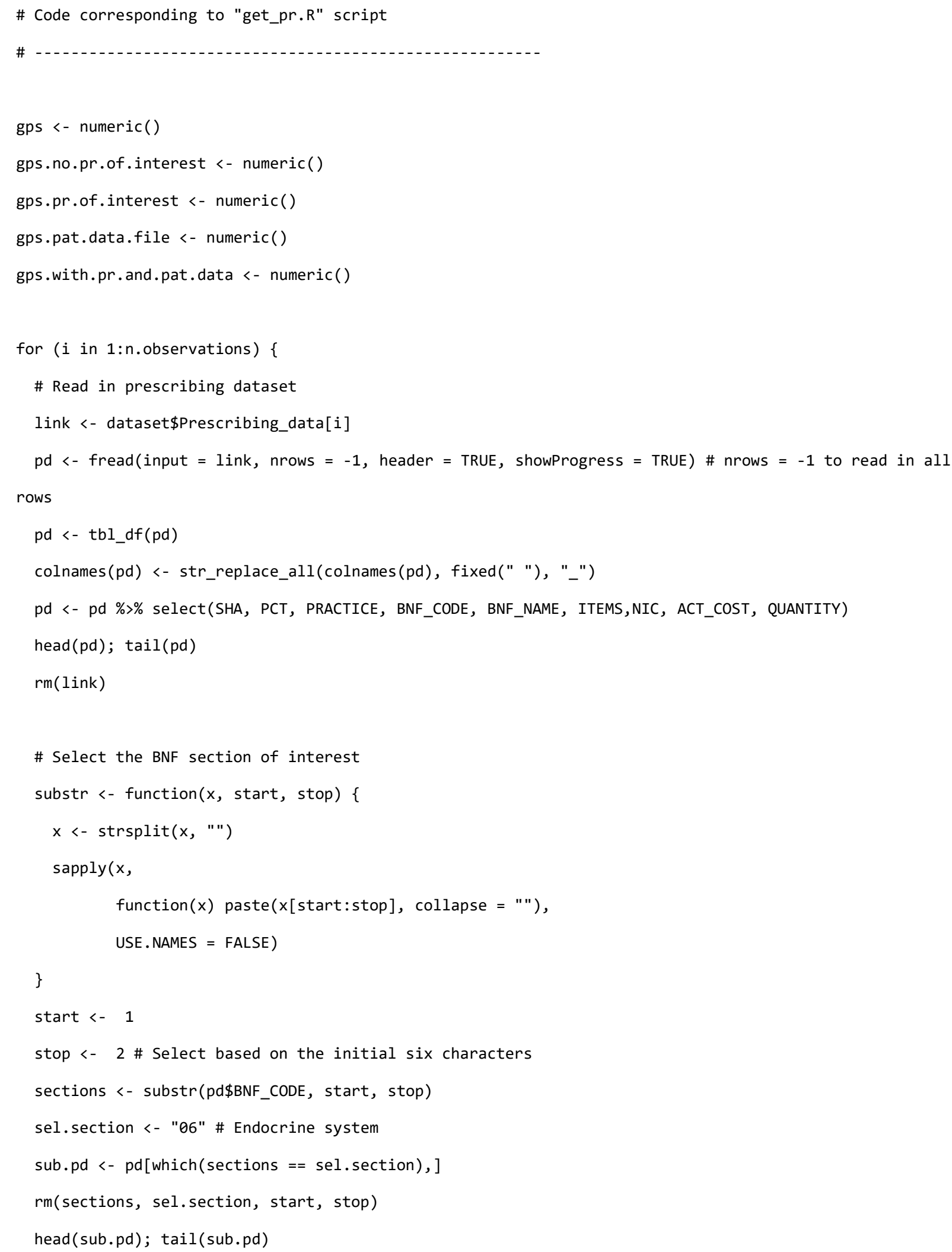







\# Calculate the proportions of each chemical

\# This code will manipulate the data to allow the assessment of potential differences in the treatment mix across England,

\# as well as the evolution of the treatment mix over time.

start $<-3$

stop $<-9$

chemicals <- substr(sub.sub.pd\$BNF_CODE, start, stop)

sub.sub.pd.ext<- sub.sub.pd \%>\%

mutate $($ CHEMICALS = chemicals) $\% \gg \%$

mutate $\left(C O S T \_D E N O S \_A L L=0\right.$, COST_ALEN_ALL $=0$, COST_ALEN_COL_ALL $=0$, COST_IBAN_ALL $=0$, COST_RISEN_ALL

$=0$, COST_SR_ALL $=0$, COST_ZOL_ALL $=0) \%>\%$

mutate(COST_DENOS_ALL $=$ replace(COST_DENOS_ALL, which (chemicals $==\quad$ sel. .chem1),

ACT_COST $[$ which $($ chemicals $==$ sel.chem 1$)])) \%$

mutate(COST_ALEN_ALL = $\quad$ replace(COST_ALEN_ALL, which (chemicals $==\quad$ sel. .chem2),

ACT_COST $[$ which $($ chemicals $==$ sel.chem 2$)])$ ) \% \%

mutate(COST_ALEN_COL_ALL $=$ replace(COST_ALEN_COL_ALL, which (chemicals $==$ sel.chem3),

ACT_COST $[$ which $($ chemicals $==$ sel.chem 3$)])$ ) \% \%

mutate(COST_IBAN_ALL = $\quad$ replace $($ COST_IBAN_ALL, which $($ chemicals $==\quad$ sel. .chem4),

ACT_COST $[$ which $($ chemicals $==$ sel.chem4)] )) \% \%

mutate(COST_RISEN_ALL $=$ replace(COST_RISEN_ALL, which(chemicals $==$ sel. chem5),

ACT_COST $[$ which $($ chemicals $==$ sel.chem5)] )) \%>\%

mutate $\left(\right.$ COST_SR_ALL $=$ replace $\left(C O S T \_S R \_A L L\right.$, which $($ chemicals $==$ sel. chem6), ACT_COST $[$ which $($ chemicals $==$ sel.chem6)])) \%>\%

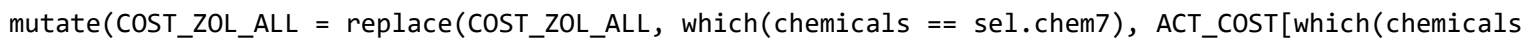

$==\operatorname{sel}(\cdot(h e m 7)])$ )

\# Group costs by practice and type of chemical

sub.sub.pd.ext.group <- sub.sub.pd.ext \%>\%

group_by (PRACTICE, CHEMICALS) \% \%

summarise $($ ITEMS = sum(ITEMS),

$\mathrm{NIC}=\operatorname{sum}(\mathrm{NIC})$,

ACT_COST $=\operatorname{sum}($ ACT_COST $)$,

COST_DENOS $=$ sum $\left(C O S T \_D E N O S \_A L L\right)$,

COST_ALEN = sum(COST_ALEN_ALL),

COST_ALEN_COL = Sum $\left(C O S T \_A L E N \_C O L \_A L L\right)$,

COST_IBAN $=$ sum $($ COST_IBAN_ALL $)$,

COST_RISEN = SUm(COST_RISEN_ALL),

COST_SR $=$ sum $\left(C O S T \_S R \_A L L\right)$, 
COST_ZOL $=$ sum $\left(C O S T \_Z O L \_A L L\right)$

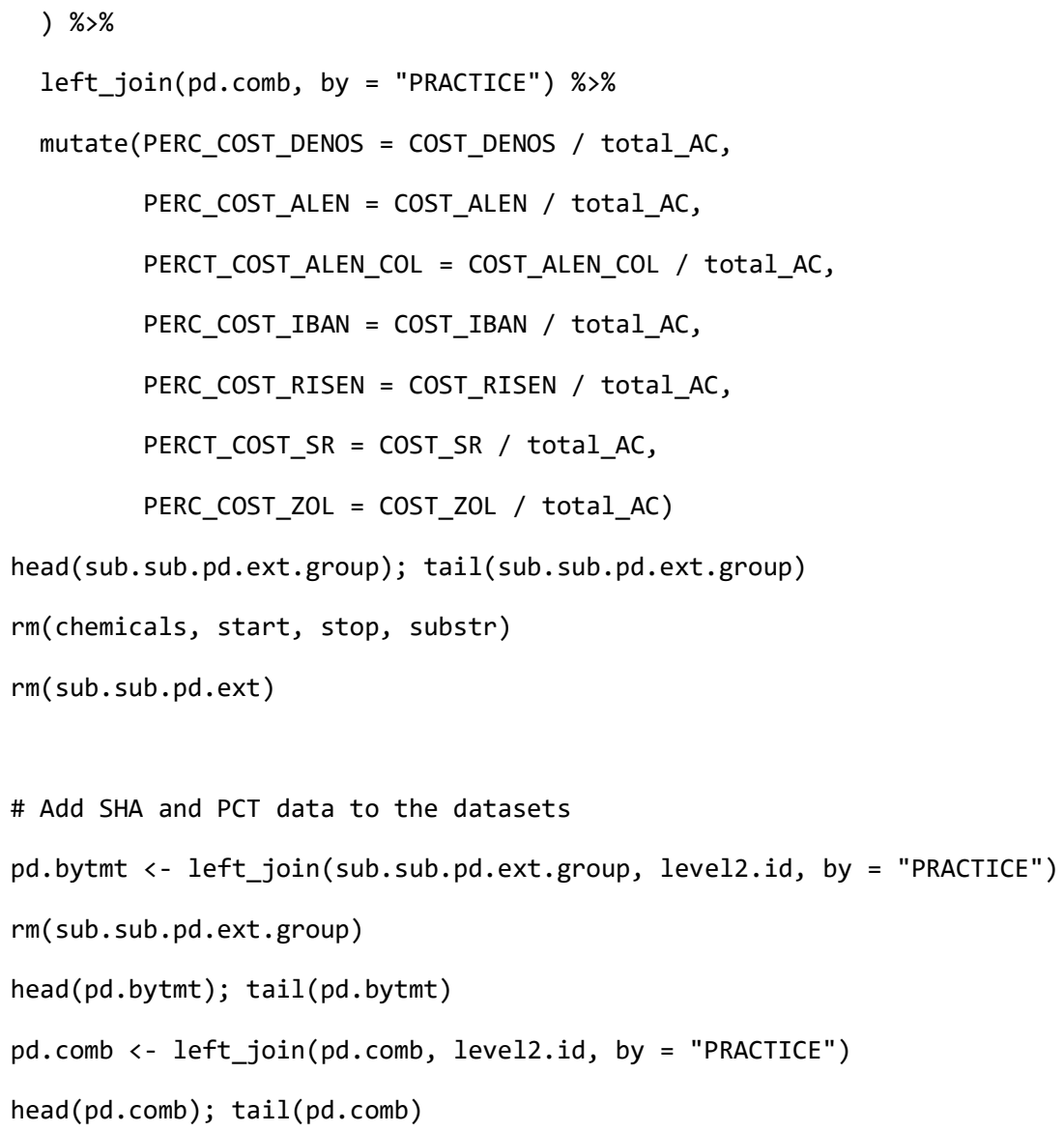

\} else \{print(paste日(nrow(level2.id)-nrow(pd.comb), " practices did not prescribe any of the drugs of interest"))\}

gps.no.pr.of.interest <- c(gps.no.pr.of.interest, nrow(level2.id)-nrow(pd.comb))

gps.pr.of.interest <- c(gps.pr.of.interest, nrow(pd.comb))

\# Code for including explicitly rows for drugs not prescribed (include zeros) in the extended and grouped (pd.bytmt) dataset

\# Produce all possible combinations of practices and prescription drugs of interest

le $<-\operatorname{nrow}($ level2.id)

sel.chems <- c(rep(sel.chem1, le), rep(sel.chem2, le), rep(sel.chem3, le), rep(sel.chem4, le), rep(sel.chem5, le), $\operatorname{rep}(\operatorname{sel} . c h e m 6, l e), \operatorname{rep}(\operatorname{sel} . c h e m 7, l e)$ )

all.poss.comb <- bind_rows(level2.id, level2.id, level2.id, level2.id, level2.id, level2.id, level2.id) $\%>\%$

bind_cols (CHEMICALS $=$ sel. chems $)$ 
rm(le, level2.id, sel.chem1, sel.chem2, sel.chem3, sel.chem4, sel.chem5, sel.chem6, sel.chem7, sel.chems)

\# Extract all combinations available in the prescription dataset

all.avail.comb <- data_frame(SHA = pd.bytmt\$SHA, PCT = pd.bytmt\$PCT, PRACTICE = pd.bytmt\$PRACTICE, CHEMICALS $=$ pd. bytmt $\$$ CHEMICALS $)$

\# Select combinations in "all.possible.combinations" that do not have a match in "all.available.combinations"

zero.pr <- setdiff(all.poss.comb, all.avail.comb)

rm(all.avail.comb, all.poss.comb)

\# Create data frame of zeros for variables other than "PRACTICE" and "CHEMICALS"

$m<-\operatorname{nrow}(z e r o . p r)$

$\mathrm{n}$ <- ncol(pd.bytmt) - 4 \# "PRACTICE" and "CHEMICALS" are already available in the "zero.pr" data frame.

zeros.df <- data.frame $\left(\operatorname{matrix}\left(\right.\right.$ data $=\operatorname{rep}\left(0, m^{*} n\right)$, nrow $=m$, ncol $\left.\left.=n\right)\right)$

colnames(zeros.df) <- colnames (pd.bytmt $[3:($ ncol (pd.bytmt) - 2)])

$\mathrm{rm}(\mathrm{m}, \mathrm{n})$

\# Generate final zeros data frame

zero.pr <- bind_cols(zero.pr, zeros.df)

$\mathrm{rm}($ zeros.df)

\# Bind the data frame reporting zeros with the prescription dataset

\# THIS IS THE FINAL EXTENDED AND GROUPED DATASET:

pd2. bytmt <- bind_rows(pd.bytmt, zero.pr)

rm(pd.bytmt, zero.pr)

\# Dataset with item numbers

pd.items <- sub.sub.pd \%>\%

group_by(PRACTICE) \%>\%

summarise (total_ITEMS = sum(ITEMS $)$ )

\# Generate the dataset combining prescription data per GP practice

pd2.comb <- left_join(pd.comb, pd.items, by = "PRACTICE")

pd2. bytmt. red <- pd2. bytmt \%>\%

select(PRACTICE, SHA, PCT, CHEMICALS, ITEMS, NIC, ACT_COST)

rm(pd.comb, pd.items, sub.sub.pd)

head(pd2.bytmt); tail (pd2.bytmt)

head(pd2.bytmt.red); tail(pd2.bytmt.red)

head (pd2.comb); head (pd2.comb) 
\# Combine datasets with the corresponding patient characteristics datasets:

\# Read in the corresponding patient characteristics data file (use "setwd" if working directory is different)

pat.filename <- paste0("pat.data_", dataset\$Year[i], dataset\$Month[i], ".csv")

pat.data <- read_csv(paste0("C:/Users/iagirrez/Desktop/Personal/UPNA/Data/Prescribing/Patient data files/", pat.filename))

\# Number of practices in each dataset, to compare

gps.pat.data.file <- c(gps.pat.data.file, length(unique(pat.data\$PRACTICE)))

\# Combine datasets: use inner_join to capture only practices for which patient characteristics are available.

\# The other data points (practices) will not be considered to avoid issues with potential patient identification

\# in practices with low patient numbers (< 100 patients).

pd2.bytmt.with.pat <- inner_join(pd2.bytmt, pat.data, by = "PRACTICE")

pd2.bytmt.red.with.pat <- inner_join(pd2.bytmt.red, pat.data, by = "PRACTICE")

pd2.comb.with.pat <- inner_join(pd2.comb, pat.data, by = "PRACTICE")

gps.with.pr.and.pat.data <- c(gps.with.pr.and.pat.data, length(unique(pd2.bytmt.with.pat\$PRACTICE)))

rm(pat.data, pat.filename, pd2.bytmt, pd2.bytmt.red, pd2.comb)

\# Combine datasets with the deprivation datasets:

\# Read in the deprivation data file

depr <- read_csv("deprivation-by-postcode.csv") \# This is available on the internet

\# Combine datasets with deprivation data

pd2.bytmt.with.pat.depr <- left_join(pd2.bytmt.with.pat, depr, by = "POSTCODE")

pd2.bytmt.red.with.pat.depr <- left_join(pd2.bytmt.red.with.pat, depr, by = "POSTCODE")

pd2.comb.with.pat.depr <- left_join(pd2.comb.with.pat, depr, by = "POSTCODE")

rm(depr, pd2.bytmt.with.pat, pd2.bytmt.red.with.pat, pd2.comb.with.pat)

\# IMPORTANT NOTE: This dataset (depr) includes ethnicity data and rural/urban category.

\# Add month and year

\# - - - - - - - - - - - -

pd2.bytmt.with.pat.depr <- pd2.bytmt.with.pat.depr \%>\%

$\operatorname{mutate}(\operatorname{MONTH}=\operatorname{dataset}[[i, 2]], \operatorname{YEAR}=\operatorname{dataset}[[i, 1]])$ 
pd2.bytmt.red.with.pat.depr <- pd2.bytmt.red.with.pat.depr $\%>$

$\operatorname{mutate}($ MONTH $=\operatorname{dataset}[[i, 2]]$, YEAR $=\operatorname{dataset}[[i, 1]])$

pd2. comb.with.pat.depr <- pd2.comb.with.pat.depr \%>\%

mutate $($ MONTH $=\operatorname{dataset}[[i, 2]]$, YEAR $=\operatorname{dataset}[[i, 1]])$ 


\section{Combine all monthly datasets into a single dataset}

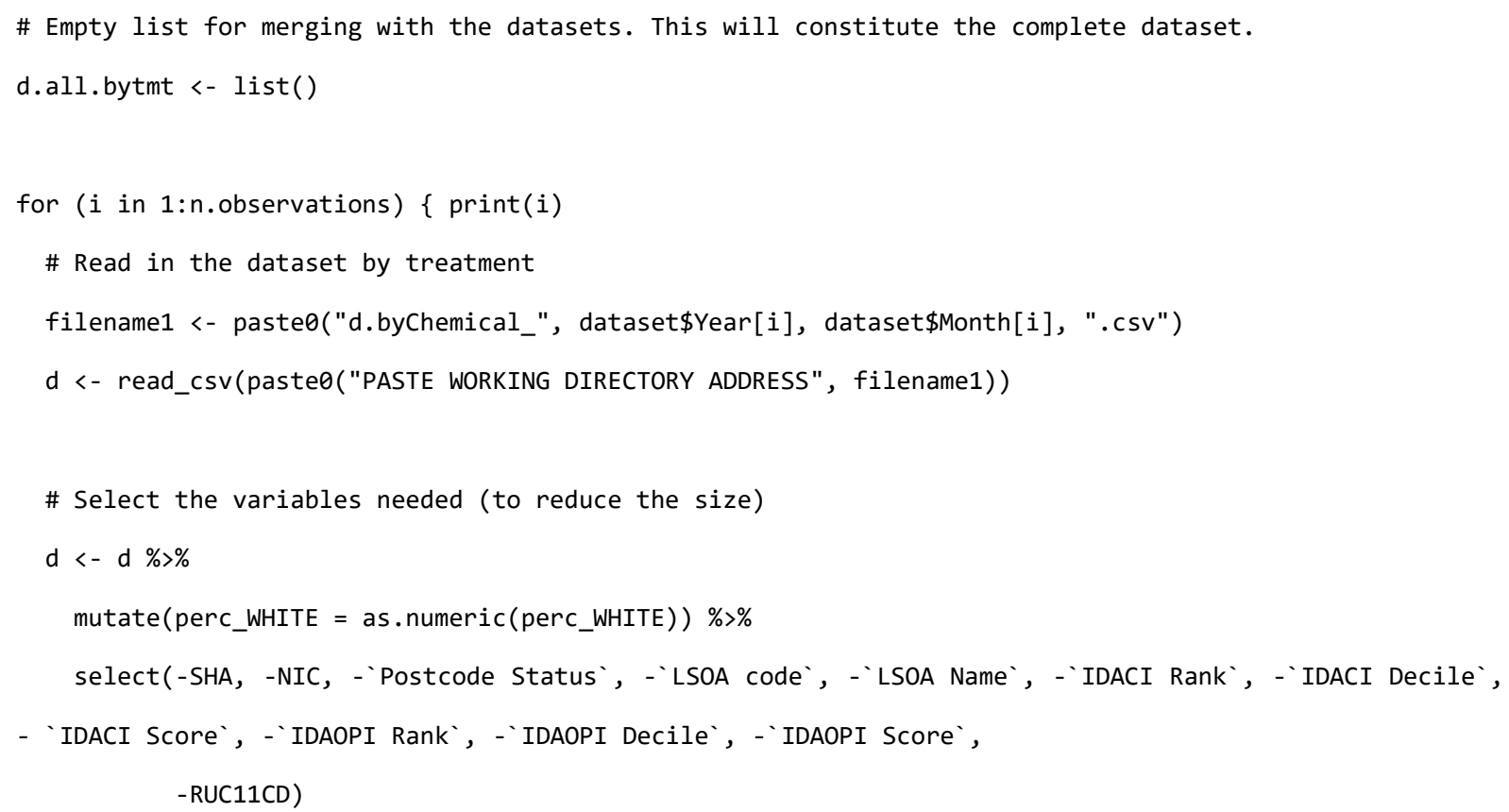


MONTH. num = replace(MONTH.num, which (MONTH.num == "December"), 11/12)

) $\%>\%$

mutate(time. num $=$ as. numeric $($ YEAR $)+\operatorname{as}$. numeric $($ MONTH. num $))$

\# Add other mutations

d_all_bytmt <- d_all_bytmt \%>\%

mutate(NUMBER_OF_PATIENTS_1000s = NUMBER_OF_PATIENTS / 1000,

perc_INCOME_score $=$ 'Income Score` $* 100$,

perc_EMPLOYMENT_score = 'Employment Score` * 100,

IMD_rank_1000s = 'Index of Multiple Deprivation Rank' / 1000,

educ_rank_1000s = 'Education and Skills Rank' / 1000,

health_rank_1000s = 'Health and Disability Rank' / 1000,

crime_rank_1000s = 'Crime Rank' / 1000,

housing_rank_1000s = 'Barriers to Housing and Services Rank' / 1000,

envir_rank_1000s = 'Living Environment Rank' / 1000,

perc_WHITE $=100 *$ perc_WHITE)

\# Set working directory for saving the newly created file

\# Write the data as an .csv file

filename <- "d_all_bytmt.csv"

write.csv(d_all_bytmt, file = filename, row. names $=$ FALSE)

$\mathrm{rm}($ filename) 


\title{
Calculate concentration indices and plot concentration curves
}

\author{
library (gridExtra) \\ library(RColorBrewer) \\ library (magrittr) \\ library(multipanelfigure) \\ library(broom) \\ library(caTools)
}

\# Calculate concentration index for each treatment

\#

\# Identify chemical categories

d_all_bytmt <- d_all_bytmt \% \% filter(CHEMICALS != "06020X0")

chemicals <- unique(d_all_bytmt\$CHEMICALS)

\# Chemicals' names

chemicals.names <- chemicals

chemicals.names[which(chemicals $==$ "06020A0")] <- "Alendronic acid"

chemicals.names[which(chemicals == "06020Y0")] <- "Alendronic acid and colecalciferol"

chemicals.names[which(chemicals == "06020z0")] <- "Denosumab"

chemicals.names[which(chemicals $==$ "06020w0")] <- "Ibandronic acid"

chemicals.names[which(chemicals == "04011X0")] <- "Raloxifene"

chemicals.names[which(chemicals == "06020R0")] <- "Risedronate sodium"

\# Identify available time points

timepoints <- unique(d_all_bytmt\$times); timepoints <- rev(timepoints)

timepoints.num <- unique(d_all_bytmt\$time.num); timepoints.num <- rev(timepoints.num)

\# Generate the objects to capture concentration indices:

\# one for easy printing and another one for creating a tbl for ggplot

conc. $m<-\operatorname{matrix}($ data $=$ NA, nrow = length (chemicals), ncol = length(timepoints $)$ )

rownames (conc.m) <- chemicals.names

colnames (conc.m) <- timepoints

names <- rep(chemicals.names, length(timepoints.num)); names <- tbl_df(names)

timepoints.rep <- numeric()

for (i in $1:$ length(timepoints.num)) \{

timepoints.rep <- c(timepoints.rep, rep(timepoints.num[i], length(chemicals.names))) 
$\mathrm{rm}(\mathrm{i})$

timepoints.rep <- tbl_df(timepoints.rep)

conc.tbl <- bind_cols(names, timepoints.rep)

\# For loop through chemicals

for ( $i$ in 1:length(chemicals)) \{

\# Filter dataset to capture the specific treatment only

d. conc <- d_all_bytmt \% \%

filter (CHEMICALS == chemicals $[i]) \%>\%$

filter(! is.na(NUMBER_OF_PATIENTS))

\# For loop through time

for ( $j$ in $1:$ length(timepoints)) \{

\# Filter dataset to capture the specific year only,

\# and arrange (sort) according to the IMD rank (from most to least deprived)

d. conc $2<-d$. conc $\%>\%$

filter(times == timepoints[j]) \%>\%

arrange('Income Rank')

\# Calculate the cumulative number of prescriptions

cumuls $<-$ d.conc $2 \%$

select(ITEMS, NUMBER_OF_PATIENTS) \%>\%

mutate $($ cumul_ITEMS_ranked = cumsum (as.numeric $($ ITEMS $))$,

perc_cumul_ITEMS_ranked $=100 *$ cumul_ITEMS_ranked / sum(as.numeric(ITEMS)),

cumul_PATS_ranked $=\operatorname{cumsum}($ as. numeric $($ NUMBER_OF_PATIENTS) $)$,

perc_cumul_PATS_ranked $=100 *$ cumul_PATS_ranked / sum(as.numeric(NUMBER_OF_PATIENTS)) $)$

$\mathrm{rm}(\mathrm{d}$. conc 2$)$

\# Calculate concentration index

auc <- trapz(cumuls\$perc_cumul_PATS_ranked / 100, cumuls\$perc_cumul_ITEMS_ranked / 100)

c.index $<-2 *(0.5-$ auc $)$

\# Assign the result to the corresponding entry in the concentration index matrix

conc.m[i, $j]<-c . i n d e x$

rm(auc, c.index) 


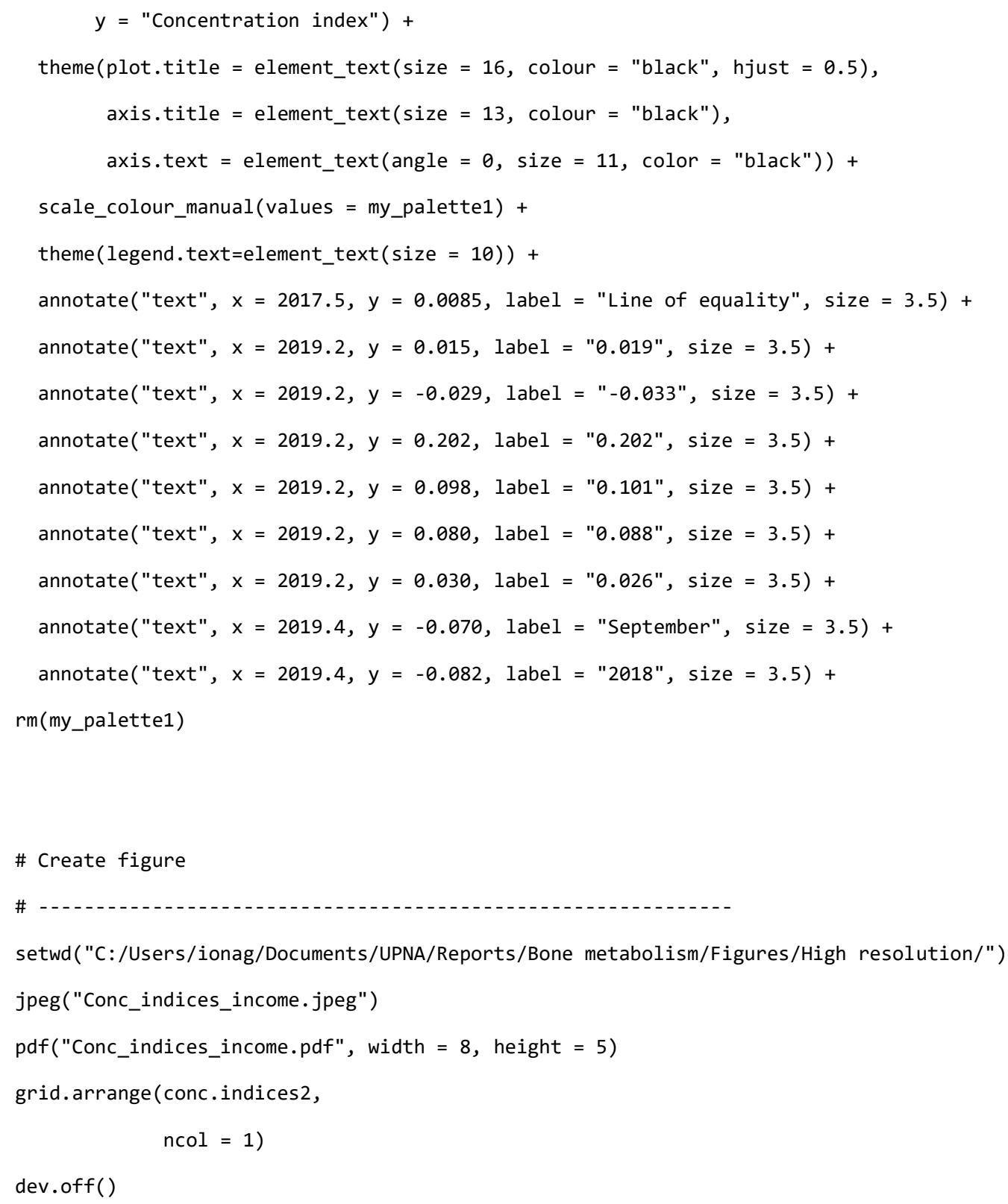

